


\section{INERVAÇÃO DO DIAFRAGMA DE OVINOS}

Tese apresentada à Faculdade de Medicina

Veterinária e Zootecnia da Universidade de São

Paulo, para obtenção do título de Doutor

\section{Departamento:}

Cirurgia

Área de concentração:

Anatomia dos Animais Domésticos

\section{Orientadora:}

Prof $^{a}$ Dr $^{\mathrm{a}}$ Irvênia Luiza de Santis Prada 


\section{Dedico}

Ao meu pai Claude (in memorian)

Pai, escrevi mais uma página do livro da minha vida

Que o senhor um dia prefacion

Saudades eternas

À minha mãe Maria da Glória

Seu apoio foi fundamental

Para a minha conquista

Meu carinho

Minha gratidão 
Ao meu marido Carlos Alberto

Sua cumplicidade e colaboração

Ajudaram-me a transpor

Os obstáculos

Meu amor

Meu reconhecimento

Alos meus filhos Luciana e Carlos Felipe

A compreensão e o incentivo de vocês

Levaram à minha vitória

Meu amor

Meu afeto

"Se você pensa que pode ou sonha que pode, comece. Ousadia tem genialidade, poder e magia. Ouse fazer e o poder the será dado"

Autor desconhecido 


\section{Agradecimentos Especiais}

\section{À Profa. Dra Irvênia Luiza de Santis Prada}

Seu exemplo, palavras e ensinamentos mantiveram-me no firme propósito de continuar, quando muitas vezes tive vontade de desistir, por tudo que vi e vivi.

Meu reconhecimento

Minha admiração

"As pessoas têm estrelas que não são as mesmas. Para uns, que viajam, as estrelas são guias. Para outros, elas não passam de pequenas luzes. Tu, porém, terás estrelas como ninguém" 


\section{Agradecimentos}

A Deus, por estar ao meu lado sempre.

À minha avó Sylvandira Pacheco de Miranda, pelo carinho infinito.

À minha irmã Cláudia Maria Fernandes de Souza Fontes, pelas palavras de incentivo constante.

À minha sogra Helenita de Araújo Almeida, pelo carinho em acolher a minha familia.

À minha querida amiga Márcia Maria Magalhães Dantas de Faria, companheira de tantas jornadas, pelo seu companheirismo incansável.

Ao Prof. Dr. Othon Jambeiro, Dice-Reitor da UfBAA, pela confiança e amizade.

Aos amigos Adelmar Afonso de Amorim Júnior e Marleyne José Afonso Accioly Lins Amorim, pela colaboração na confecção da tese e principalmente pela amizade fraternal.

Aos Colegas do Curso de Pós-Graduação, pela amizade e convivência.

Ao Prof $f^{0}$ Dr. Wilson Machado de Souza, pelas oportunas sugestões e doação de alguns artigos. 
Aos Professores do Curso de Pós-Graduação da FMVZ/USP, em particular a Profi. Dra. Arani Nancy Bonfim Mariana, pelo apoio e experiências.

Aos Funcionários do Setor de Anatomia dos Animais Domésticos da FMVZ/USP, pelo convívio e colaboração constantes.

Ao Serviço de Biblioteca da fMDZ/USD, em especial aos amigos Rosa Maria Fischi Zani, Maria Inês Charelli de Camargo, Maria Cláudia Pestana e Ana Cristina Ponciano da Silva, exemplos de competência, pelas colaborações amigas.

Aos amigos Sandra e Anair Faria, pela receptividade e convivência.

đ̀ Escola de Medicina Veterinária da UFBA e Faculdade de Medicina Veterinária e Zootecnia da USP, pela oportunidade da continuidade dos estudos de pós-graduação.

À CAPES, pelo incentivo financeiro.

À Profa. Drá. Fátima Dias Costa, Coordenadora de Ensino de Pós-Graduação da UfBAA, pela amizade e estímulo.

A Maisa Sales de Souza, Chefe do Setor de Bolsas da Pró -Reitoria de

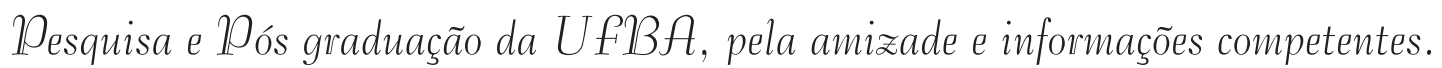

đ̀ Profa. Dra. Maria das Graças Farias Pinto, Chefe do Departamento de Anatomia dos Animais Domésticos da EMD/UfBA, pela amizade e apoio constantes. 
Aos Professores Antonio Carlos Basto Baracho, Ardson José Leal, Heitor Portela Povoas e Wilma de Albuquerque Franco, pelas oportunidades oferecidas na Anatomia Deterinária da EMD /UfBA.

Às Professoras Substitutas do Departamento de Anatomia dos Animais Domésticos da EMV/UFBA, por assumirem com competência minhas atividades docentes.

Ao Profo. Dr. Luciano José Costa Figueiredo, pela confiança, incentivo e apoio constantes.

Ao Prof. Geraldo Cezar de Vinhaes Torres, pela amizade e convívio.

Às amigas Ana Íris Oliveira Menezes, Lílian Novaes Ribeiro, Maria Celeste Viana de Souza e Solange Caxico Martins, pela corrente positiva e amizade sincera.

À amiga Elizabeth Villar Palma, pelas palavras de incentivo.

A Rands Tadeu Palma Ferreira, pelo auxílio na confecção da tese e pela amizade.

À amiga Lílian Isis Azevedo Barbosa pelo carinho, colaboração e convivência.

A Tadeu Miranda, pelo competente trabalho fotográfico do material.

À Profa. Flávia Garcia Rosa, Diretora da Editora da UfBA, à Gabriela Nascimento, Ângela Dantas Garcia Rosa, Alana Gonçalves Carvalho e Rogério Santos Amaral - Designers gráficos e a Secretária Esmeralda Maria Barbosa, pelo auxílio na parte gráfica e colaboração permanente. 
À Profa. Heleohene Pereira Barbosa, pela amizade e auxilio nas traduções em inglês.

Ao funcionário do Departamento de Anatomia dos Animais Domésticos da EMD-UfBA, Carlos Antônio de Oliveira, pela colaboração no preparo do material coletado.

Aos amigos Edvaldo de Jesus Santos e Geraldino Dias de Souza, pelo auxilio na coleta do material utilizado.

Ao amigo Judicael Afetal de Sousa, por ceder a fotografia do exemplar ovino da raça Santa Inês.

À Fazenda Mucambo, por facilitar os meios para a obtenção dos exemplares ovinos.

A Williams Roberto Martins Santos, pela confecção dos esquemas contidos nesta tese.

E a todos que direta e indiretamente, seja pelo incentivo, apoio ou amizade, colaboraram para a realização deste trabalho tão importante para minha vida profissional, o meu sincero agradecimento. 
"Todos os homens sonham, mas não de maneira igual. Aqueles que sonham a noite, acordam no dia seguinte para descobrir que não passou de vaidade, mas os que sonham acordados são homens perigosos, porque tecem seus sonhos de olhos abertos para torná-los realidade. foi o que fiz". 


\section{RESUMO}

ALMEIDA, A. E. F. de S. Inervação do diafragma de ovinos. [Innervation of the diaphragm of Ovines]. 2002. 212 f. Tese (Doutorado em Anatomia dos Animais Domésticos) - Faculdade de Medicina Veterinária e Zootecnia, Universidade de São Paulo, São Paulo.

Foram estudados em 30 diafragmas de ovinos da raça Santa Inês, a origem, a divisão e a distribuição dos nervos frênicos direito e esquerdo, bem como a participação de outros nervos na inervação do diafragma. Mediante fixação e dissecação das peças foi observado que os nervos frênicos originam-se mais freqüentemente a partir dos ramos ventrais do $5^{\circ}(\mathrm{C} 5)$ e $6^{\circ}$ (C6) nervos espinhais cervicais tanto à direita $(46,67 \%)$ como à esquerda $(43,33 \%)$. Os nervos frênicos terminam mais constantemente em tronco lombocostal e ramo esternal à direita $(40,00 \%)$ e em ramos lombar, costal e esternal à esquerda (36,68\%). Os ramos lombares dos nervos frênicos inervam mais freqüentemente à esquerda (96,67\%) somente o pilar homolateral do diafragma e à direita $(50,00 \%)$ fornecem também filetes à veia cava caudal. Os ramos costais dos nervos frênicos inervam à esquerda $(90,00 \%)$ e à direita $(76,67 \%)$ somente as regiões dorsal e ventral da pars costalis. Os ramos esternais dos nervos frênicos inervam à direita (100,00\%) e à esquerda (83,33\%) somente a pars sternalis e a região ventral da pars costalis do mesmo lado. Os nervos intercostais (VIII ao XII pares - 63,33\%) contribuem na inervação do diafragma de ovinos da raça Santa Inês.

Unitermos : Anatomia; Ovinos; Diafragma animal; Sistema nervoso. 


\section{SUMMARY}

ALMEIDA, A. E. F de S. Innervation of the diaphragm of ovines. [Inervação do diafragma de ovinos]. 2002. 212 f. Tese (Doutorado em Anatomia dos Animais Domésticos) - Faculdade de Medicina Veterinária e Zootecnia, Universidade de São Paulo, São Paulo.

There were studied 30 diaphragms of ovines from Santa Inês race, their origin, division and the arrangement of the right and left phrenic nerves, as well as the participation of other nerves in the innervation of diaphragm. By fixing and dissecting pieces, it was registered that phrenic neves frequently come from the vental branches of the $5^{\text {th }}(\mathrm{C} 5)$ and $6^{\text {th }}(\mathrm{C} 6)$ cervical spinal nerves as at right $(46,67 \%)$ as at left $(43,33 \%)$. The phrenic nerves often result in a lumbocostal trunk and esternal branch at right $(40,00 \%)$ and in lumbar, costal and esternal branches at left $(36,68 \%)$. The lumbar branches of phrenic nerves innervate frequently at left $(96,67 \%)$ only the homolateral pillar of the diaphragma and at right $(50,00 \%)$ give fillets to vena cava caudalis The costal branches of phrenic nerves innervate at left $(90,00 \%)$ and at right $(76,67 \%)$ only the dorsal and ventral regions of the pars costalis. The esternal branches of the phrenic nerves innervate at right $(100,00 \%)$ and at left $(83,33 \%)$ only the pars sternalis and the ventral region of the pars costalis at the same side. The intercostal nerves (VIII to XII pairs $63,33 \%$ ) contribute to innervate the diaphragm of ovines of Santa Inês race.

Uniterms: Anatomy; Ovines; Animal diaphragm ; Nervous System. 
SUMÁRIO

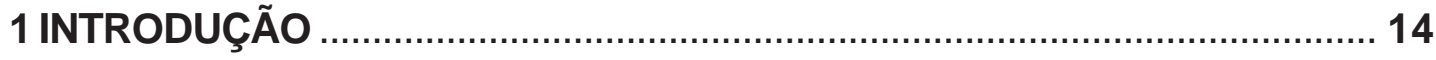

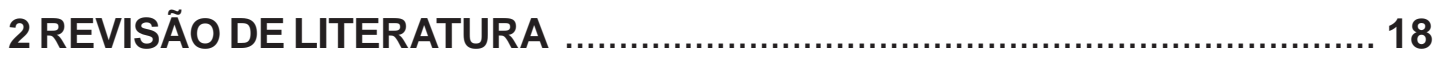

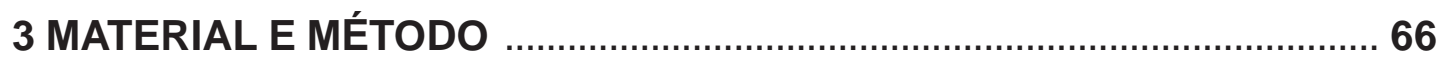

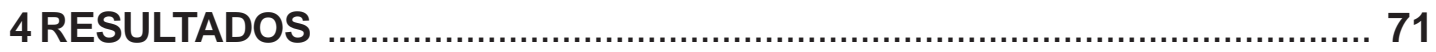

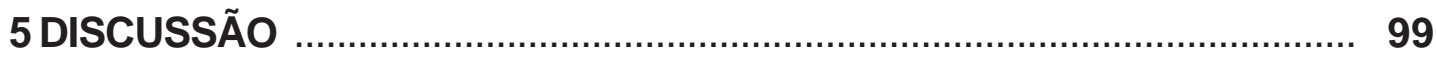

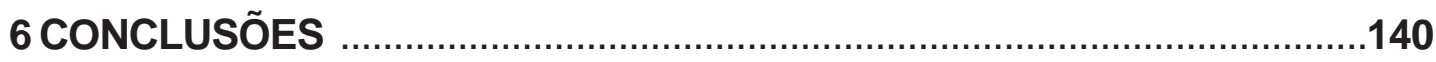

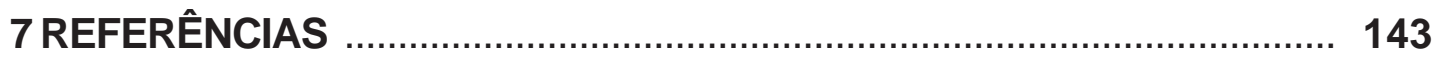

ANEXOS 
Introdução 
O diafragma, ao dispor-se, nos mamíferos, entre as cavidades do tórax e do abdome, apresenta uma parte central tendínea e uma parte periférica muscular, na qual se distinguem, em cada antímero, as porções lombar, costal e esternal. Apesar desta aparente simplicidade o diafragma é complexo quanto ao modo de sua formação e à sua estrutura, posto que se desenvolve a partir de quatro fontes, segundo AREY (1964): do septum transversum, seu principal componente ventral; das membranas pleuroperitoneais e da parede corpórea, suas partes dorsolaterais e ventrolaterais, respectivamente; do mesoesôfago, sua porção mediodorsal. Além dessa origem diversificada, associa-se a ocorrência de migração do esboço muscular cervical para integrar o diafragma em sua localização definitiva, a que se atribuí a característica de sua principal inervação pelo nervo frênico (GONZÁLEZ Y GARCIA e GONZÁLEZ ALVAREZ, 1949).

Várias pesquisas não apenas em relação à anatomia humana, a exemplo de LOCCHI (1932a,b), como no atinente à anatomia veterinária, a exemplo de BERTELLI (1894) apud CONDE (1957); BERTELLI (1895, 1933); ZIMMERL (1909); ANDREI (1928); CONDE (1957); ROMER e PARSONS (1985) e DYCE et al. (1990) informam que o nervo frênico constitui a principal, e provavelmente única, fonte de inervação motora do diafragma. Por outro lado, na opinião de CAVALIÉ (1898) e FELIX (1922) apud ROSENBLUETH et al. (1961), os nervos intercostais também contribuem com fibras motoras para essa inervação.

Com o grande desenvolvimento das cirurgias torácicas, novas técnicas cirúrgicas têm sido propostas, exigindo algumas, uma secção do diafragma, para exposição de órgãos torácicos e abdominais; porém a incisão praticada nesse músculo lesa, muitas vezes, ramificações nervosas terminais relativamente importantes às funções do diafragma (respiração, principalmente). 
Considerando a peculiaridade de sua origem embriológica, houve interesse em se estudar a inervação do diafragma para se verificar a validade da "Hipótese de Fürbringer" (LOCCHI, 1932C) apud DALECK (1991), segundo a qual todas as formações musculares conservam sempre sua inervação primitiva, apesar da ocorrência de migração de esboços musculares.

Portanto, muitos são os aspectos anatômicos da inervação do diafragma, que nos interessam ao abordarmos os ovinos da raça Santa Inês, envolvidos tanto no comportamento dos nervos frênicos (sua origem, divisão e distribuição) quanto na possibilidade de contribuição de nervos intercostais e lombares.

Entretanto, a literatura consultada, seja referente aos periódicos, seja relativa aos tratados de Anatomia Comparativa, traz-nos poucas informações a respeito do assunto em tela, sendo que as extraídas dos livros textos, mesmo quando alusivas a caprinos e ovinos, tratam-nos sob o título genérico de pequenos ruminantes.

Outro aspecto que nos motiva a desenvolver esta pesquisa é que a ovinocultura é uma atividade econômica em franca expansão, estando presente em áreas sob as mais diversas características climáticas, edáficas e botânicas. Segundo LIMA (1999) o Brasil tem hoje, aproximadamente, 18 milhões de ovinos incluindo todas as raças criadas no país e a região Nordeste possui 7,2 milhões de ovinos correspondendo a 39\% do rebanho nacional, sendo que o Estado da Bahia concentra os maiores plantéis desta espécie, com 2,8 milhões de cabeças (LEITE, 2000)

Largamente explorados, de forma extensiva, estes animais têm aumentado seu contingente populacional graças à rusticidade e à adaptação ao meio ambiente, 
fato que possibilitou o surgimento de algumas raças, a exemplo da Santa Inês formada principalmente a partir de ovinos da raça Morada Nova brasileira com ovinos da raça italiana Bergamácia (MACHADO, 1999) e que veio para satisfazer um velho desejo dos criadores de possuir um animal modelo com qualidades especiais em tamanho, peso, rusticidade, prolificidade e beleza, agregando tudo isso no resultado final que é a viabilidade econômica.

Sem dúvida a ovinocultura tropical tem sofrido transformações radicais nos diversos elos da cadeia produtiva em decorrência de uma notória expansão dos mercados interno e externo. A grande competição que emerge entre os mercados produtivos tem provocado uma busca incessante por novos conhecimentos técnicos e gerenciais (OLIVEIRA, 2000)

Assim, considerando o interesse pelo conhecimento do diafragma, tanto no sentido morfológico como no funcional e dada a importância zootécnica e econômica dos ovinos da raça Santa Inês, objetivamos com este trabalho:

- Oferecer contribuição ao conhecimento da anatomia própria deste animal tão bem adaptado a diferentes regiões do Nordeste do Brasil.

- Conhecer, nestes animais, as características da inervação do diafragma, colaborando assim, para eleger os locais de abordagem deste músculo, que preservem a sua inervação intramuscular, possibilitando, desta maneira, melhor entendimento de processos relacionados à clínica e à cirurgia destes animais. 
- Verificar os níveis das raízes nervosas que compõem os nervos frênicos direito e esquerdo na região cervical da coluna vertebral destes animais, estabelecendo também, os eventuais pontos de união destes filetes, com vistas a delimitar uma melhor região de manipulação dos aludidos nervos.

- Oferecer subsídios para alicerçar pesquisas correlatas, de caráter comparativo em Anatomia, Fisiologia e Embriologia entre animais deste mesmo grupo (ruminantes), como também entre as espécies de não ruminantes.

- Apresentar dados que poderão embasar o estabelecimento de eventuais diferenças raciais.

- Fornecer contribuição à literatura sobre o assunto. 
Revisão de Literatura 
O estudo anatômico da origem e curso dos nervos frênicos bem como da distribuição de seus ramos terminais no diafragma, já foi objeto de inúmeras publicações relativamente a animais domésticos e silvestres. Entretanto, poucas foram as pesquisas similares ao presente trabalho, que procuraram evidenciar possível participação de outros nervos, além dos nervos frênicos, na inervação do diafragma.

No que tange aos tratadistas veterinários consultados, verificamos que grande parte deles limita-se a descrever de modo suscinto e genérico, para as espécies domésticas a origem, divisões e distribuição dos nervos frênicos no diafragma, não se referindo a outros nervos, que possam participar dessa inervação, tema que estudaremos em ovinos da raça Santa Inês.

Assim, alguns dos autores desses tratados, referindo-se à origem dos nervos frênicos, sem citarem a espécie animal, a exemplo de CHAUVEAU et al. (1905b); LESBRE (1923); ZIMMERL (1909, 1930); ELLENBERGER e BAUM (1932); DOBBERSTEIN e HOFFMAN (1964); SCHWARZE e SCHRÖDER (1972); NICKEL et al. (1977) e DYCE et al. (1990) descrevem os nervos frênicos como emergentes do $5^{\circ}, 6^{\circ}$ e $7^{\circ}$ nervos cervicais, sendo que suas raízes correm junto ao músculo escaleno em direção ao tórax, unindo-se em uma só estrutura que se dirige ao diafragma para formar sua inervação motora. Já GONZÁLEZY GARCÍA e GONZÁLEZ ALVAREZ (1929) relatam que os nervos frênicos nascem em um ponto da medula espinhal bastante distante do diafragma, ou seja, do $6^{\circ}$ par de nervos cervicais. Afirmação semelhante é feita por SCHWARZE e SCHRÖDER (1972) para ovinos. GHOSHAL (1975) cita para os ruminantes que os nervos frênicos são formados pela união dos ramos ventrais do $5^{\circ}, 6^{\circ}$, e $7^{\circ}$ nervos cervicais e acrescenta para os ovinos e caprinos que a contribuição do $7^{\circ}$ nervo cervical ou é pequena ou está ausente. BARONE (1989) indica que as raízes 
dos nervos frênicos provêm dos três ou quatro penúltimos nervos cervicais. EVANS (1993) comenta o surgimento dos nervos frênicos, no cão, a partir do $5^{\circ}, 6^{\circ} \mathrm{e} / \mathrm{ou}$ $7^{\circ}$ nervos cervicais, referindo-se ainda, a uma ocasional participação de pequeno ramo do $4^{\circ}$ nervo cervical.

Quanto à divisão e distribuição dos nervos frênicos, estes tratadistas também fazem, de alguma forma, alusão. Tal é o caso de ZIMMERL (1909); LESBRE (1923); ELLENBERGER e BAUM (1932) e GONZÁLEZ Y GARCÍA e GONZÁLEZ ALVAREZ (1949) os quais, de modo geral, comentam apenas que os nervos frênicos chegam ao centro frênico e se distribuem à porção carnosa depois de sucessivas divisões. Ainda CHAUVEAU et al. (1905a) e LESBRE (1923) mencionam a presença de fino ramo dirigido aos pilares, afirmação que se assemelha à exarada por ZIMMERL (1930) segundo o qual um ou mais filetes nervosos são destinados exclusivamente ao pilares. SCHWARZE e SCHRÖDER (1972) citam que os referidos nervos emitem vários ramos ao diafragma, os quais inervam as porções correspondentes. EVANS (1993) comenta, para o cão, que cada nervo frênico divide-se em três ramos principais: dorsal, lateral e ventral.

Relativamente à participação de outros nervos no suprimento nervoso do diafragma, apenas BARONE (1989) acrescenta a descrição genérica de que finos filetes dos nervos intercostais mergulham na porção carnosa periférica do diafragma.

No atinente às publicações especializadas relacionadas ao tema desta pesquisa, vimos que a maioria delas dedica especial atenção à sistematização da divisão terminal dos nervos frênicos em várias espécies animais; outros trabaIhos comentam sobre os níveis de origem do nervo frênico e outro grupo realiza pesquisas experimentais com este nervo. Pouco ou quase nada é referido pelos 
autores sobre a participação de outros nervos na inervação do diafragma das muitas espécies pesquisadas.

Dividiremos este tópico em duas partes:

1) Literatura referente aos ruminantes

2) Literatura referente a outras espécies (não ruminantes)

\section{1) Literatura referente aos ruminantes}

PANCRAZI (1925), ao descrever a disposição do nervo frênico e suas divisões no bovino e também em outras espécies (cavalo, cobaia, coelho, cão e gato), informa genericamente que os principais ramos terminais são em número de três e denomina-os como propôs BERTELLI (1894, 1895, 1933), de ventral, lateral e dorsal. O primeiro provê a inervação da parte esternal e, quase sempre, daquele segmento da parte costal que se insere no folíolo ventral, enquanto o segundo é responsável pela inervação da parte costal restante e o terceiro alcança a parte lombar. Menciona, outrossim, para os bovinos, a presença de um ramúsculo do ramo dorsal esquerdo a atingir o pilar direito, enquanto o ramo lateral e o ventral originam-se, em quase todas as oportunidades, tanto à direita quanto à esquerda, de um tronco comum, com o ramo dorsal nascendo mais alto e independente. O autor esclarece que a subdivisão dos nervos frênicos varia segundo a espécie e entre representantes da mesma espécie.

JANSEN (1931) apud MIGLINO (1982) estuda experimentalmente os nervos frênicos em 38 cabras, mostrando claramente que a secção de um deles deter- 
mina degeneração da metade correspondente do diafragma, sendo a divisão representada pela linha mediana referendada pelo hiato esofágico.

LUTNICKI (1950), em seu trabalho sobre os nervos frênicos em carneiros, inclusive fetos, trata principalmente da origem desses nervos, chegando a conclusão de que em $84 \%$ dos casos, os nervos frênicos originam-se de C5, C6 e fino ramo de $\mathrm{C7}$. Afirma ainda o autor, que em todas as peças, estes nervos dividemse em três ramos suprindo as partes correspondentes do músculo. Sobre o lado esquerdo do diafragma, comenta o autor, aparece um quarto ramo, o qual passa para o lado direito do músculo, contornando o esôfago.

GIROLLA (1955) disseca os nervos frênicos de 53 bovinos, sendo 3 adultos, 8 novilhos e 42 fetos e observa que estes nervos formam-se bilateralmente, em $86,30 \%$ dos casos, a partir de três raízes originadas dos ramos ventrais de $C 5$, C6, C7 e que em $39,00 \%$ dos animais analisados não há a terceira raiz no lado direito, enquanto em $98,00 \%$ das oportunidades, surge uma outra raiz neste mesmo lado, a partir do ramo ventral do $4^{\circ}$ nervo cervical. $O$ autor relata ainda que o nervo frênico esquerdo divide-se em um ramo dorsal e um tronco que em seguida, antes de atingir o diafragma, fornece o ramo lateral e o ramo ventral. $O$ ramo dorsal alcança o pilar medial esquerdo do diafragma, ao qual fornece uma ramificação e distribui-se na musculatura do pilar direito. O ramo lateral inerva a parte costal, penetrando ao nível da segunda e terceira digitações costais. $O$ ramo ventral emite filetes à parte costal no seu percurso e passa à parte esternal, ligando-se a filetes do ramo ventral do lado oposto. O nervo frênico direito divide-se em ramo dorsal e em um tronco que se subdivide em ramos lateral e ventral. O ramo dorsal distribui-se nos pilares medial e lateral direito, sendo que em um feto, ele emite um ramúsculo que penetra na parte costal direita. O ramo 
lateral ramifica-se na parte costal. O ramo ventral penetra na primeira digitação costal e, ramificando-se no seu percurso, atinge a parte esternal, cedendo-lhe inúmeros filetes que se unem aos filetes do ramo ventral do lado oposto.

NEVES (1968), ao examinar a distribuição dos nervos frênicos no diafragma de 30 fetos de bovinos sem raça definida, apresenta-nos as seguintes conclusões:

1) Os nervos frênicos terminam por bifurcação em ramo dorsal e tronco ventrolateral mais freqüentemente à direita $(90,00 \%)$ e à esquerda $(83,30 \%)$ do que por bifurcação em ramo ventral e tronco dorsolateral (6,60\% à esquerda) e por trifurcação em ramos dorsal, ventral e lateral (10,00\% à direita e à esquerda).

2) A disposição bifurcada em ramo dorsal e tronco ventrolateral, ocorre tanto no macho $(85,00 \%$ à direita e $80,00 \%$ à esquerda) quanto na fêmea $(100,00 \%$ à direita e 90,00\% à esquerda).

3) Considerados os nervos frênicos direito e esquerdo, combinados, há distribuição simétrica dos ramos terminais dos nervos frênicos no diafragma de bovinos, pois $76,60 \%$ dos casos examinados apresentam-se bifurcados em ramo dorsal e tronco ventrolateral, sendo $70,00 \%$ de machos e $90,00 \%$ de fêmeas.

4) A distribuição homolateral do ramo dorsal direito é predominante em $96,60 \%$ dos casos, de vez que o ramo esquerdo contribui em $80,00 \%$ dos casos para a inervação do pilar do lado oposto mediante um ramo heterolateral.

5) Os ramos laterais inervam predominantemente os feixes musculares costais correspondentes em 100,00\% dos casos à direita e $96,60 \%$ à esquerda. 
6) Os ramos ventrais distribuem-se predominantemente na porção ventral da parte costal e nas partes esternais em $76,60 \%$ dos casos à direita e em $86,60 \%$ à esquerda.

7) Anastomoses foram observadas entre os ramos ventral e lateral, lateral e dorsal, lateral e ventral, dorsal e lateral. Estas uniões eram homolaterais em $100,00 \%$ dos casos.

8) Pela aplicação do Teste de Associação, verificou-se que não há interferência do fator sexo e distribuição dos nervos frênicos, tudo ocorrendo pelo acaso.

BAMEL et al. (1970) examinam os nervos frênicos em 51 machos da espécie bubalina (Bos bubalis) entre 1 a 2 anos de idade. Observam que cada nervo é formado pelos ramos ventrais do $5^{\circ}, 6^{\circ}$ e $7^{\circ}$ nervos cervicais. A raiz derivada do $5^{0}$ nervo cervical é a mais larga e mais longa, enquanto aquela derivada do $7^{0}$ nervo é a menor. Caso de variação bilateral na formação do nervo frênico é também notada. Os autores relatam ainda que o nervo frênico direito divide-se em ramos dorsal, lateral e ventral. O ramo dorsal passa caudodorsalmente para inervar a musculatura dorsal e o pilar direito do diafragma. O ramo lateral ramifica-se na parte lateral direita do órgão enquanto a divisão terminal ventral supre a parte esternal do diafragma. O nervo frênico esquerdo ramifica-se na metade esquerda do diafragma de modo semelhante ao nervo frênico direito. Caso de inervação cruzada dos dois nervos frênicos não é observado em búfalo.

FERREIRA et al. (1973) estudam a distribuição dos ramos terminais dos nervos frênicos em 30 diafragmas de ovinos adultos, machos, da raça Corriedale, e apresentam os seguintes resultados: 
1 - Os nervos frênicos terminam em ramo dorsal e tronco ventrolateral, 9 vezes $(30,00 \%)$ à esquerda e 6 vezes $(20,00 \%)$ à direita; em ramo ventral e tronco dorsolateral, 12 vezes (40,00\%), em ambos os antímeros.

2 - A terminação dos nervos frênicos em trifurcação foi encontrada 7 vezes $(23,50 \%)$ à esquerda e 3 vezes (10,00\%) à direita.

3 - A divisão terminal dos nervos frênicos apresenta disposição simétrica somente em 10 casos $(33,30 \%)$.

Os autores ressaltam que também estudaram a distribuição dos ramos dorsais, ventrais e laterais, além de certos filetes denominados "acessórios", situados entre os troncos principais, mas não descrevem tais resultados.

MIA (1973) determina para o diafragma de zebuínos (Bos indicus), suprimento nervoso derivado principalmente dos nervos frênicos, sendo o esquerdo comparativamente mais longo que o direito, devido à posição assimétrica do coração, fazendo menção a ramos torácicos internos, pleurais e pericárdicos. Acrescenta o citado autor que o frênico direito divide-se em 3 ramos (ventral, lateral e dorsal) que se lançam no terço correspondente de cada metade do diafragma enquanto que o esquerdo, usualmente, oferece 2 principais ramos terminais: ramo dorsal (pilar esquerdo) e ramo ventral (metade remanescente do diafragma), referindose ainda à inervação heterolateral dada pelos ramos dorsais. Relata ainda, que os pilares do diafragma são inervados pelos ramos ventrais do primeiro e segundo nervos lombares, enquanto as inserções costais recebem filamentos dos ramos ventrais dos seis últimos nervos intercostais. 
MIGLINO (1982), em trabalho de dissertação de mestrado sobre a divisão e distribuição dos nervos frênicos no diafragma em caprinos (Capra hircus - L., 1758), chega às seguintes conclusões:

1) Os nervos frênicos dos caprinos examinados terminam por bifurcação em ramo dorsal e tronco ventrolateral, mais freqüentemente, tanto à direita $(40,00 \%)$ como à esquerda (80,00\%), encontrando-se ainda a divisão por trifurcação dos ramos dorsal, ventral e lateral à direita (32,50\%) e à esquerda (12,50\%), assim como a resolução em ramo ventral e tronco dorsolateral seja no primeiro dos lados $(27,50 \%)$, seja no segundo $(7,50 \%)$.

2) Os nervos frênicos direito e esquerdo dividem-se simetricamente por bifurcação em ramo dorsal e tronco ventrolateral (35,00\%), por trifurcação $(7,50 \%)$ ou por bifurcação em ramo ventral e tronco dorsolateral $(2,50 \%)$.

3) O ramo dorsal, quer do nervo frênico direito (2,50\%) quer do nervo esquerdo $(7,50 \%)$ oferece eventualmente distribuição heterolateral.

4) Os ramos dorsais dos nervos frênicos inervam à direita (50,00\%) e à esquerda $(75,00 \%)$, somente a parte lombar homolateral. Nos outros casos, à direita (50,00\%) e à esquerda (25,00\%), distribuem-se também a outras estruturas, ou seja: à direita $(25,00 \%)$, à veia cava caudal; à direita (12,50\%) e à esquerda $(12,50 \%)$, ao folíolo dorsal; à direita (10,00\%), à veia cava caudal e ao folíolo dorsal, simultaneamente.

5) Os ramos laterais dos nervos frênicos inervam à direita (67,50\%) e à esquerda $(77,50 \%)$ somente à parte costal, mais exatamente, as porções dorsal e lateral sempre e, ainda por vezes, a porção ventral tanto à direita (10,00\%) quanto à 
esquerda (30,00\%). Nas preparações restantes, à direita (32,50\%) e à esquerda (22,50\%), distribuem-se também a outras estruturas, isto é: à direita (30,00\%) e à esquerda (17,50\%), ao folíolo dorsal; à direita (2,50\%), à veia cava caudal.

6) Os ramos ventrais inervam à direita $(42,50 \%)$ e à esquerda $(50,00 \%)$, somente a porção ventral da parte costal e a parte esternal do mesmo lado. Nas outras peças, à direita $(57,50 \%)$ e à esquerda $(50,00 \%)$, exibem outros arranjos de distribuição, ou seja: à direita (17,50\%) e à esquerda (12,50\%), inervam também o folíolo ventral; à direita $(7,50 \%)$ e à esquerda $(20,00 \%)$, ainda à parte esternal oposta, além da veia cava caudal; à direita $(10,00 \%)$ apenas a porção ventral da parte costal; à direita $(7,50 \%)$ e à esquerda $(5,00 \%)$, as porções lateral e ventral da parte costal e parte esternal; à direita (10,00\%) e à esquerda (5,00\%), essas regiões e o folíolo ventral; à esquerda (2,50\%), ainda tais regiões e a parte esternal direita; à direita $(5,00 \%)$, a porção ventral da parte costal direita e o folíolo ventral; à esquerda (5,00\%), apenas as porções lateral e ventral da parte costal.

7) Conexões ("anastomoses") homolaterais são encontradas: à direita (22,50\%) e à esquerda (12,50\%), entre as próprias divisões do ramo dorsal; à direita $(17,50 \%)$ e à esquerda (12,50\%), entre filetes do ramo lateral; à direita (15,00\%) e à esquerda (17,50\%), entre filetes do ramo dorsal e entre filetes do ramo lateral simultaneamente; à esquerda (2,50\%), entre filetes do ramo dorsal e filetes do ramo dorsal quando derivados do tronco ventrolaterodorsal.

SOUZA et al. (1984), ao analisarem a inervação de 30 diafragmas de bovinos adultos, machos, da raça Nelore, estabelecem os resultados adiante enumerados: 
1) Os nervos frênicos, mais freqüentemente, fornecem um ramo dorsal e tronco ventrolateral (60,00\% à direita e à esquerda).

2) A origem dos ramos dorsal, lateral e ventral, mediante trifurcação, não constitui ocorrência rara (23,30\% à direita e 30,00\% à esquerda).

3) Com menor freqüência, os nervos frênicos cedem tronco dorsalateral e ramo ventral (16,60\% à direita e 10,00\% à esquerda).

4) Os ramos dorsais dos nervos frênicos destinam-se sempre à porção lombar correspondente, sendo que o direito $(30,00 \%)$ pode alcançar a veia cava caudal e, o esquerdo, a região lombar direita $(73,30 \%)$.

5) O ramo lateral do nervo frênico direito inerva exclusivamente a porção costal correspondente $(100,00 \%)$, fato também observado em relação ao esquerdo que, algumas vezes $(10,00 \%)$, atinge a região lombar esquerda.

6) Os ramos ventrais dos nervos frênicos distribuem-se, principalmente, nas porções ventrais (esternais) correspondentes.

7) Conexões ("anastomoses") entre contribuições dos nervos frênicos direito e esquerdo foram assinaladas apenas entre os ramos dorsais (6,70\%).

MIGLINO et al. (1985) utilizam 30 diafragmas de búfalos adultos da raça Jaffarabadi, machos, e descrevem:

1) Os nervos frênicos examinados terminam por bifurcação em ramo dorsal e tronco ventrolateral, à direita $(26,60 \%)$, à esquerda $(86,60 \%)$ e simetricamente 
(26,60\%), encontrando-se ainda a divisão por trifurcação nos ramos dorsal, lateral e ventral à direita $(20,00 \%)$, à esquerda $(13,30 \%)$ e simetricamente $(6,60 \%)$, assim como a resolução em ramo ventral e tronco dorsolateral apenas à direita $(53,30 \%)$. Considerada a ramificação dos nervos frênicos direito e esquerdo em conjunto, nota-se que se resolvem ambos em ramo dorsal e tronco ventrolateral (46,60\%), ou ainda em bifurcação à direita em ramo ventral e tronco dorsolateral e trifurcação à esquerda $(5,00 \%)$.

2) Os ramos dorsais dos nervos frênicos inervam à direita (26,60\%) e à esquerda $(73,30 \%)$, somente a parte lombar homolateral. Nos outros casos, distribuem-se também a outras estruturas, ou seja, ao folíolo dorsal à direita $(6,60 \%)$ e à esquerda (3,30\%), à veia cava caudal, à direita (40,00\%), à veia cava caudal e folíolo dorsal direito (10,00\%), à porção dorsal da parte costal, folíolo dorsal e veia cava caudal à direita (6,60\%), e à parte lombar oposta mediante filete derivado do ramo dorsal esquerdo que cruza ventralmente o hiato esofágico e dirige-se para a parte lombar direita $(23,30 \%)$.

3) Os ramos laterais dos nervos frênicos inervam a parte costal tanto à direita como à esquerda, ou seja, as porções dorsal e lateral sempre e ainda a porção ventral à direita $(26,60 \%)$ e à esquerda $(46,30 \%)$, podendo ainda distribuir-se por outras estruturas, ou seja, folíolo dorsal à direita $(6,60 \%)$ e à esquerda $(3,30 \%)$.

4) Os ramos ventrais dos nervos frênicos direito e esquerdo inervam apenas a porção ventral da parte costal e parte esternal homóloga, à direita $(33,30 \%)$ e à esquerda (26,60\%), mostrando-se ainda, na maioria das observações, a inervar, à direita, além da parte esternal homóloga, as porções lateral e ventral da parte costal (53,30\%), a porção ventral da parte costal e toda à parte esternal do músculo, homóloga e oposta, à direita (6,60\%), à esquerda (46,60\%), ou mesmo, à 
esquerda, as porções lateral e ventral da parte costal e toda à parte esternal, correspondente e oposta (20,00\%), como também a porção ventral da parte costal esquerda, toda à parte esternal e ainda parte costal oposta $(6,60 \%)$.

5) Conexões ("anastomoses") entre as derivações do ramo dorsal direito ocorrem em rara oportunidade $(3,30 \%)$ ou na mesma percentagem entre filetes do citado ramo que se dispõem contornando a veia cava caudal. Observa-se ainda união de filete nervoso derivado do ramo dorsal esquerdo, anastomosando-se com filete do ramo dorsal oposto (3,30\%) e, finalmente, registram-se conexões entre filetes do ramo dorsal direito e ramo lateral direito $(16,60 \%)$.

MIGLINO et al. (1985), ao analisarem a ramificação e distribuição dos nervos frênicos direito e esquerdo em 10 diafragmas de ovinos da raça Ideal, 7 machos e 3 fêmeas, adultos, apresentam as seguintes conclusões:

1) Os nervos frênicos cedem ramo dorsal e tronco ventrolateral à direita $(40,00 \%)$ e à esquerda $(30,00 \%)$; simultaneamente os ramos dorsal, lateral e ventral à direita $(30,00 \%)$ e à esquerda $(20,00 \%)$ e ainda ramo ventral e tronco dorsolateral, à direita $(30,00 \%)$ e à esquerda $(50,00 \%)$.

2) Em conjunto os nervos frênicos apresentam disposição simétrica nos seguintes arranjos: ramo dorsal e tronco ventrolateral $(20,00 \%)$, ramos dorsal, lateral e ventral $(10,00 \%)$ e ramo ventral e tronco dorsolateral $(20,00 \%)$.

3) Os ramos dorsais dos nervos frênicos direito e esquerdo inervam somente as partes lombares homolaterais, enquanto que os ramos laterais distribuem-se somente às partes costais (porção laterodorsal) homólogas. 
4) Os ramos ventrais inervam além das partes esternais correspondentes, as partes costais (porção lateroventral) sempre à direita (100,00\%) e à esquerda (90,00\%), distribuindo-se também à esquerda na parte esternal oposta (10,00\%).

SOUZA et al. (1985), em estudo acerca dos níveis de origem dos nervos frênicos, em 40 fetos de bovinos azebuados, com diferentes idades, sendo 28 machos e 12 fêmeas, apresentam-nos as seguintes conclusões:

1) Os nervos frênicos, nos bovinos azebuados, originam-se mais freqüentemente a partir das raízes ventrais do 5ํㅜ $6^{\circ}$ e $7^{\circ}$ nervos cervicais tanto à direita $(90,00 \%)$ como à esquerda $(86,50 \%)$.

2) A origem dos nervos frênicos mediante as raízes ventrais apenas do 6ํe do $7^{0}$ nervos cervicais, não constitui uma ocorrência rara, nos bovinos azebuados, ou seja, $10,00 \%$ à direita e $12,50 \%$ à esquerda.

3) A união das raízes formadoras dos nervos frênicos direito e esquerdo, nos bovinos azebuados, ocorre no interior da caixa torácica, vale dizer sob a $1^{\underline{a}}, 2^{\underline{a}}$, $3^{\text {a }}$ ou 4ํㅡㄹ costelas e espaços intercostais correspondentes, tanto à direita como à esquerda.

4) As abordagens dos nervos frênicos direito ou esquerdo, nos bovinos azebuados, devem ser realizadas no interior da caixa torácica e após o 4ํำ par de costelas.

5) Os nervos frênicos, dos bovinos azebuados, têm origem simétrica, isto é, a partir de um mesmo número de raízes nervosas à direita e à esquerda em 82,50\% das preparações e origem assimétrica em $17,50 \%$ dos casos. 
6) Nas dissecações em que tanto o nervo frênico direito como o nervo frênico esquerdo tomam origem a partir de três raízes, ou seja, das raízes ventrais do 5ㄴ, $6^{\circ}$ e $7^{\circ}$ nervos cervicais, a raiz do $6^{\circ}$ se une à do $7^{\circ}$ constituindo um pequeno tronco que posteriormente se reúne com a raiz procedente do $5^{\circ}$ nervo cervical.

TOCANTINS NETO (1985), com base na dissecção de 30 diafragmas de búfalos, adultos, machos da raça Murrah, estuda a divisão e a distribuição dos nervos frênicos em seu trabalho de dissertação de mestrado e chega às seguintes conclusões:

1) Os nervos frênicos terminam por bifurcação, tanto à direita (36,70\%), quanto à esquerda $(100,00 \%)$, em ramo dorsal e tronco ventrolateral.

2) Os nervos frênicos terminam por bifurcação, somente à direita (46,70\%), em ramo ventral e tronco dorsolateral.

3) Os nervos frênicos terminam por trifurcação, apenas à direita (16,70\%), em ramos dorsal, lateral e ventral.

4) Os nervos frênicos dividem-se simetricamente (40,00\%) por bifurcação, em ramo dorsal e tronco ventrolateral.

5) Os nervos frênicos, em conjunto, terminam à direita $(50,00 \%)$ em ramo ventral e tronco dorsolateral e, à esquerda (50,00\%), bifurcam-se em ramo dorsal e tronco ventrolateral.

6) Os nervos frênicos, em conjunto, terminam à direita (10,00\%) trifurcando-se em ramos dorsal, lateral e ventral e, à esquerda (10,00\%) bifurcando-se em ramo dorsal e tronco ventrolateral. 
7) Os ramos dorsais dos nervos frênicos inervam à direita (73,30\%) e à esquerda $(76,70 \%)$ a parte lombar homolateral; nos outros casos, à direita $(26,60 \%)$ e à esquerda (23,30\%) distribuem-se também a outras estruturas, tais como: à direita $(20,00 \%)$, à veia cava caudal; à esquerda $(23,30 \%)$ à pequena região da parte lombar direita; à direita $(3,30 \%)$, à região dorsolateral da parte costal do mesmo lado e, à direita (3,30\%), à veia cava caudal e ao folíolo dorsal direito.

8) Os ramos laterais dos nervos frênicos inervam à direita (93,30\%) e à esquerda (100,00\%) as porções dorsolateral e ventrolateral da parte costal; à direita (6,70\%), às porções dorsolateral e ventrolateral da parte costal e o folíolo dorsal direito.

9) Os ramos ventrais dos nervos frênicos dirigem-se à direita (93,30\%) e à esquerda $(86,70 \%)$ à porção ventrolateral da parte costal e parte esternal do mesmo lado; à direita (3,30\%), somente à porção ventrolateral da parte costal direita; à esquerda (10,00\%), à porção ventrolateral da parte costal e parte esternal homolateralmente, além da parte esternal contralateral; à direita (3,30\%) à porção ventrolateral da parte costal direita e folíolo ventral; à esquerda (3,30\%), à porção ventrolateral da parte costal esquerda e parte esternal do mesmo lado, além do folíolo ventral.

10) Existem anastomoses nervosas homolaterais à direita (3,30\%) entre o ramo dorsal direito e o lateral do mesmo lado, além de outra, entre o referido ramo anastomótico e um filete derivado do ramo dorsal que se distribui na região dorsolateral da parte costal; à esquerda (3,30\%), entre filetes do ramo lateral do nervo frênico esquerdo; à esquerda (3,30\%), entre ramúsculo do próprio ramo dorsal do nervo frênico do mesmo lado. 
PRADA et al. (1987) descrevem a ramificação dos nervos frênicos no diafragma de 20 ovinos deslanados, machos e fêmeas, jovens e adultos, chegando às seguintes informações:

1) Os nervos frênicos dividem-se em ramo dorsal e tronco ventrolateral à direita (5,00\%) e à esquerda (25,00\%); simultaneamente em 3 ramos, dorsal, lateral e ventral à direita (40,00\%) e à esquerda (45,00\%), e em 4 ramos, 1 dorsal, 2 laterais e 1 ventral, 1 vez à direita e à esquerda, ou mesmo ramo ventral e tronco dorsolateral, à direita (55,00\%) e à esquerda (30,00\%).

2) Analisando a ramificação dos nervos frênicos em conjunto, verificam disposições simétricas em 3 preparações, em 2 das quais (10,00\%) os ramos dorsal, lateral e ventral emergem simultaneamente sendo que na restante $(5,00 \%)$, os citados nervos fornecem um ramo ventral e tronco dorsolateral.

3) Relativamente à distribuição dos nervos frênicos, com base na análise de 10 peças, observam que os ramos dorsais direito e esquerdo distribuem-se sempre na parte lombar homolateral, podendo emitir filete nervoso ao folíolo dorsal direito $(5,00 \%)$.

4) Os ramos laterais direito e esquerdo inervam sempre a região laterodorsal da parte costal.

5) Os ramos ventrais distribuem-se nas partes esternal e costal (porção lateroventral) à direita $(30,00 \%)$ e à esquerda $(25,00 \%)$; somente na parte costal (porção lateroventral) à direita (20,00\%) e à esquerda (5,00\%) e ainda à esquerda, na parte costal (porção lateroventral) e na parte esternal homo e heterolateral. 
MIGLINO et al. (1993) observam a disposição morfológica e a inervação do diafragma de 9 veados mateiros (Manzana americana), 5 machos e 4 fêmeas, 1 de veado catingueiro (Manzana simplicicornis) macho e 1 de veado do rabo branco (Blastocerus bezoarticus) macho, adultos, oriundos de diversas regiões do Pantanal matogrossense, Brasil. Mediante fixação em solução aquosa de formol a $10 \%$ e pelo método da dissecação, os autores verificam que os diafragmas das três espécies são pouco espessos, possuem porção carnosa periférica reduzida, um centro tendíneo (folíolos) amplo e delgado e pilares robustos. Quando consideradas em conjunto as três espécies, os nervos frênicos dividem-se por trifurcação (45,00\% à direita e 18,20\% à esquerda) e por bifurcação (ramo dorsal e tronco lateroventral - 36,40\% à direita e $54,50 \%$ à esquerda e ramo ventral e tronco laterodorsal - $18,20 \%$ à direita e $27,30 \%$ à esquerda), percentagens sem diferença estatisticamente significante entre os dois lados. Os autores descrevem ainda que os ramos dorsais dos nervos frênicos direito e esquerdo inervam nas três espécies pesquisadas as partes lombares homólogas. Podem, entretanto, distribuir-se a outras estruturas, tais como: o folíolo dorsal em 27,30\% bilateralmente; parede da veia cava caudal (22,00\% à direita e 33,30\% à esquerda) e a região dorsal da parte costal (11,10\%) em ambos os lados. Relatam também que no veado catingueiro (Manzana simplicicornis) ocorre inervação heterolateral dada por filete do ramo dorsal direito, endereçado à parte lombar oposta e informam que os ramos laterais nas três espécies estudadas inervam sempre a região laterodorsal da parte costal correspondente enquanto os ramos ventrais inervam a região lateroventral da parte costal e parte esternal correspondentes. Descrevem ainda que apenas em um caso ocorre um grupo de fibras musculares no folíolo ventral, inervadas por filete derivado do ramo ventral, ocorrendo conexões homolaterais entre filetes derivados do ramo dorsal. 


\section{2) Literatura referente a outras espécies (não ruminantes)}

PANSINI (1888) apud BERTELLI (1933) estuda ao microscópio a inervação do diafragma de cobaia, coelho, rato branco, cão e gato neonatos. Ocupa-se principalmente dos plexos e dos gânglios. A respeito da distribuição dos nervos frênicos no diafragma limita-se a descrever as disposições desenhadas em figura, reproduzindo a ramificação desses nervos no diafragma de um coelho, distinguindo-se um ramo anterior, um ramo posterior e ramos laterais.

BERTELLI (1894) apud CONDE (1957) descreve que, no cão, o nervo frênico direito atinge o diafragma e divide-se em 3 ramos principais, dos quais 2 penetram na porção costal, enquanto o outro atravessa o folíolo dorsal direito. $O$ frênico esquerdo divide-se em 3 ou 4 ramos; um atravessa o folíolo esquerdo e dirigese ao pilar esquerdo, ao passo que os outros se lançam na porção costal.

BERTELLI (1895), no seu trabalho sobre morfologia do diafragma, refere-se a estudo em 25 cães. Ao tratar da inervação, escreve que os nervos frênicos, atingindo o diafragma dividem-se em ramos ventral, lateral e dorsal, os quais se distribuem como nos roedores. Em roedores (cobaia) descreve: o ramo ventral se distribui ao quarto inferior da porção costal e à porção esternal, os ramos laterais (ordinariamente 2, raramente 3) se distribuem ao resto da porção costal, o ramo dorsal vai medialmente e dorsalmente através do folíolo dorsal e atinge o pilar ao qual se distribui. Na figura 6 apresentada pelo autor, relativa ao cão, os ramos dorsal e lateral de ambos os lados tomam origem de um tronco comum.

CAVALIÉ (1898) apudBERTELLI (1933), em trabalho de Anatomia Comparada sobre a distribuição do nervo frênico no diafragma de mamíferos (cão, coelho, cobaia e rato), assim se expressa: "de cada lado o nervo frênico dá um pincel de 
ramos terminais que se anastomosam amplamente com os pequenos ramos do simpático".

SCHLAEPFER (1925) relata que, 4 meses após frenicotomia unilateral esquerda em cão, havia sinais de atrofia de toda a metade correspondente do diafragma, estando a mesma, dois anos depois, completamente substituída por membrana fibrosa branca, contrastando com a musculatura do lado direito. $\mathrm{O}$ autor acrescenta que nas porções lombar, lateral e posteriormente ao esôfago, o diafragma mostra-se, do lado paralisado, completamente fibroso; à direita o músculo era normal, razão pela qual julga improcedentes as informações, freqüentemente encontradas, de que fibras musculares da porção lombar de um lado cruzam por trás do esôfago para o lado oposto.

ANDREI (1928), 15 dias a 5 meses após exérese do nervo frênico em cão, encontra, ao exame histológico da musculatura do diafragma, uma atrofia que atinge homogeneamente toda metade do diafragma, alcançando as terminações musculares que se inserem nas últimas costelas e nos pilares lombares, comprovando que também estas porções se acham, pelo menos no cão, sob a ação motora trófica do nervo frênico. $O$ autor chama a atenção para a afirmação de FELIX (1922) de que uma parte limitada do diafragma é inervada predominantemente pelos últimos nervos intercostais e, portanto, esta região não deveria atrofiar-se ou pelo menos sofrer pouca alteração em conseqüência da exérese do nervo frênico. Por esta razão, ANDREl é de opinião juntamente com aqueles autores (e são a maioria) os quais atribuem aos filamentos, que partem dos nervos intercostais e se distribuem ao diafragma, uma função sensitiva ou uma função motora insignificante. Assim, no cão, o nervo frênico aparece como o único nervo motor do diafragma, pois, após sua exérese unilateral, segue-se definitiva paralisia da correspondente metade deste músculo. 
FUNAOKA et al. (1930) apud BERTELLI (1933) examinam os nervos frênicos de 5 coelhos e 12 cães, e concluem que, nestas espécies, há 3 ramos terminais ao invés de 2. São eles, ramos diafragmáticos anterior, lateral e posterior. Os ramos anteriores suprem a porção esternal do diafragma e se anastomosam ao nível da linha mediana com ramos do lado oposto. Os ramos laterais dirigem-se à porção costal do diafragma. Os posteriores inervam a parte próxima do esôfago e da coluna vertebral.

LOCCHI (1931), em suas observações sobre o diafragma no Bradypus tridactylus descreve que o nervo frênico tem origem dos nervos cervicais $5^{\circ}, 6^{\circ} \mathrm{e}$ $7^{\circ}$, predominando a contribuição do $6^{\circ}$; em alguns recebe um filete do $4^{\circ} \mathrm{e}$ em outros do $8^{\circ}$. Antes de atingir o diafragma, os nervos frênicos, direito e esquerdo já se dividem em seus ramos terminais; esta divisão obedece ao plano geral descrito por BERTELLI (1895) para os mamíferos em geral, e já assinalado por PANCRAZI (1925) para o Bradypus tridactylus, isto é, um ramo ventral, um lateral e um dorsal.

BERTELLI (1933), dentre outras espécies, estuda no coelho, cobaia, rato e cão neonato, a distribuição dos nervos frênicos. Em todas as espécies encontra que os nervos produzem três ramos diafragmáticos, aos quais deu a denominação de ramos ventral, lateral e dorsal. Descreve que os nervos frênicos, próximos ao diafragma, dividem-se tanto à direita como à esquerda, em um segmento muito curto que dá origem a 2 ramos e um segmento muito longo que é o $3^{\circ}$ ramo. Ao segmento muito curto, denomina-o cordão frênico. No coelho existe mais freqüentemente, à direita, um cordão frênico que dá origem aos ramos ventral e lateral, saindo o dorsal separadamente. No cão neonato os 3 ramos dos nervos frênicos são muito bem manifestos. Os ramos ventrais direito e esquerdo saem separadamente e os ramos lateral e dorsal tomam origem de um curto cordão 
frênico. O ramo ventral inerva o segmento da parte costal colocado abaixo de sua origem e, ainda, à parte esternal. O ramo lateral supre a parte costal restante e o ramo dorsal distribui-se no pilar medial. Quanto à cobaia, o autor reproduz seus achados relatados antes (1895).

FONTES (1934) faz experiências com 18 cães, registrando as respostas de cada hemidiafragma às excitações dos nervos frênicos ao nível do pescoço. Fato interessante é que à excitação de um dos frênicos os dois hemidiafragmas não reagem sempre da mesma maneira. Algumas vezes ambos respondem à excitação do frênico de um só lado. Isto contradiz formalmente a afirmação de LAUNAY (1934) sobre a inexistência de inervação cruzada. O autor conclui que o nervo frênico é, pelo menos no cão, o único nervo motor do diafragma.

CARDIN (1936a), resumindo os dados obtidos em seu experimento sobre a distribuição segmentada dos nervos frênicos no diafragma de cães, utilizando a estimulação farádica das raízes destes nervos revela que:

1) Um estímulo elétrico incidindo sobre a raiz superior do nervo frênico (fibras provenientes do $5^{\circ}$ segmento cervical) determina uma contração enérgica das porções esternal e costal anterior do diafragma, irradiando menos intensamente para a porção costal posterior.

2) Ao estímulo da raiz média do nervo frênico (fibras provenientes do $6^{\circ}$ segmento cervical) segue-se contração intensa da porção costal posterior; essa estimulação, analogamente à condição observada pela raiz superior, irradia-se também para as porções esternal e costal anterior, com menor intensidade. 
3) A excitação da raiz inferior do nervo frênico (fibras provenientes do $7^{\circ}$ segmento cervical) leva a uma contração, quase totalmente circunscrita ao pilar homolateral do hemidiafragma.

Estas observações, integradas com as noções fornecidas pela anatomia microscópica, levaram o autor a concluir que, em linha geral, os três ramos de inervação motora do hemidiafragma representam a continuação, mais ou menos direta, dos fascículos nervosos, que provém separadamente da medula cervical para entrarem na constituição do tronco frênico.

CARDIN (1936b), continuando suas pesquisas sobre a inervação segmentar do diafragma, procura explicar as causas de uma parcial interdependência nervosa, sobretudo das porções costal e costo-esternal do diafragma. Estudando no cão a disposição anatômica das vias eferentes do nervo frênico, do seu ponto de inervação radicular até a inervação das porções do diafragma, o autor apresenta as seguintes considerações:

1) Existe uma anastomose múltipla entre os pequenos feixes da $5^{\frac{a}{a}}$ e $6^{\underline{a}}$ raízes cervicais e uma anastomose mais simples entre a $6^{\mathrm{a}}$ e $7^{\mathrm{a}}$ raízes cervicais. Tais anastomoses são observadas no segmento superior do tronco frênico a alguns centímetros do ponto de união dos cordões frênicos.

2) Existe uma anastomose plexiforme entre os três cordões em correspondência com a porção terminal do tronco frênico. Existem filetes nervosos entre os pequenos feixes da $5^{\underline{a}}$ e $7^{a}$ bem como da $6^{\underline{a}}$ e $7^{a}$ raízes cervicais, mas são mais numerosos entre aqueles da $5^{\underline{a}}$ e $6^{\underline{a}}$ raízes cervicais. 
Os resultados obtidos nesses experimentos levam o autor a admitir que um estímulo sobre a extremidade periférica de um ramo diafragmático ou do seu conjunto de feixes nervosos determina, no músculo, uma contração enérgica de caráter estritamente segmentado. Nota também, que no cão falta às vezes o fascículo radicular proveniente do $7^{\circ}$ segmento cervical e que, provavelmente neste caso, o hemidiafragma é inervado por dois e não três ramos nervosos.

CARDIN et al. (1937) analisam a distribuição radicular dos nervos frênicos do diafragma de cães, mediante pesquisas histo-funcionais. Neste trabalho os autores reportam-se a dados de trabalhos anteriores (CARDIN, 1936 a-b), apresentando-nos o seguinte relato: no cão, os três ramos de inervação motora do hemidiafragma representam a continuação mais ou menos direta, dos fascículos nervosos, que provêm separadamente da medula cervical para entrarem na constituição do tronco frênico. Em conseqüência deste fato, a motilidade do segmento esternocostal do diafragma está ligada à $1 \underline{\underline{a}}$ raiz frênica (C5), enquanto a $2^{2}$ (C6) auxilia o segmento costovertebral do músculo e a $3^{\text {a }}$ (C7) entra na constituição da via nervosa motora do pilar. Na tentativa de elucidar a causa que leva a uma parcial interdependência no estado funcional do segmento diafragmático de domínio radicular, cogita a existência de filamentos anastomosados, distribuídos entre os feixes radiculares da formação do nervo. Aplicadas ao cadáver humano, mediante um processo de dilaceração fascicular, estas pesquisas confirmam os resultados obtidos nos animais, demonstrando, entretanto, uma troca anastomótica de ordem mais elevada, o que faz admitir que no diafragma humano existe uma condição de mais íntima solidariedade funcional. Com a presente pesquisa os autores propuseram-se a estudar, no cão, o estado trófico e funcional do diafragma privado, parcialmente ou totalmente, de suas vias de condução motora e de examinar histologicamente o tronco frênico submetido à degeneração de um ou mais feixes nervosos. Os animais de laboratório (cobaia) foram 
operados bilateralmente (radicectomia frênica) segundo uma ordem que inclui uma (de cada vez) ou todas as 3 raízes. No $20^{\circ}$ dia de pós-operatório os animais eram sacrificados e os diafragmas expostos. Nos animais privados da $1^{\underline{a}}$ (C5) ou da $2^{\text {a }}$ (C6) raiz frênica, já na inspeção do hemidiafragma, observava-se a presença de um segmento aparentemente triangular, bem delimitado, cuja cor rosa pálido contrastava nitidamente com a coloração mais viva do tecido circunvizinho. Tal segmento não parecia distendido como o restante do músculo, mas apresentava, às vezes algumas pregas que do centro tendíneo se dirigiam, de forma radiada, em direção à periferia e, outras tantas, um abaulamento central constituído de tecido fortemente relaxado. Ao exame de palpação a borda muscular parecia pastosa e delgada. A estimulação farádica do tronco frênico não induzia neste território modificações contráteis, mas um certo grau de distensão restrito à zona marginal, e, portanto imputável à relação de contigüidade com o tecido funcional e talvez, a poucas fibras nervosas de ordem heterofascicular. As alterações funcionais, devido ao corte das raízes frênicas sobre o segmento esternocostal ou costovertebral do diafragma também se verificam sobre os pilares, em decorrência da remoção da 3ª raiz. A tal propósito deve-se acrescentar que, nesta região, e mais exatamente ao redor dos orifícios de passagem da aorta e esôfago, permaneciam alguns fascículos musculares em estado de trofismo mais ou menos conservado. A remoção bilateral das 3 raízes do nervo frênico reassume, na totalidade do tecido diafragmático, idêntica alteração segmentar que aquela conseqüente à ablação de cada raiz; isto se reveste de particular importância porque demonstra como, no diafragma do cão, somente o pequeno fascículo que do pilar de um lado se entrelaça ao pilar oposto funcionando como um esfíncter ao vaso aórtico e ao esôfago, subordina-se ao domínio motor do nervo frênico. 
LUTNICKI (1953), estudando a ramificação e distribuição dos nervos frênicos em 30 diafragmas de porco doméstico (Sus domesticus), de idade variando entre duas semanas a três meses, chega às seguintes conclusões:

1) Em $59,00 \%$ dos casos o diafragma é simetricamente inervado, isto é, seus nervos frênicos direito e esquerdo estão distribuídos em suas correspondentes metades direita e esquerda.

2) Em $27,00 \%$ das oportunidades o diafragma é assimetricamente inervado. Neste grupo o ramo dorsal esquerdo origina-se de um ramo acessório, o qual corre abaixo do hiato esofágico para o lado oposto. Este ramo contribui para a inervação da crus mediale destrum. Esta inervação assimétrica é causada pelo nervo frênico esquerdo.

3) Em 14,00\% das ocorrências, do ramo dorsal de ambos os nervos frênicos direito e esquerdo destacam-se ramos acessórios, que correm abaixo do hiato esofágico para a parte muscular da metade oposta do diafragma. Esses ramos formam plexos que se encontram ventralmente ao hiato esofágico e dessa forma, unem os nervos frênicos direito e esquerdo.

BOTHA (1957), através de estimulação farádica do nervo frênico de cão e outras espécies (rato, furão, coelho, gato e macaco) observa contração da metade ipsilateral do diafragma, ressaltando que nenhum fascículo muscular periférico ou dos pilares deixou de se contrair. Em alguns animais o ramo póstero-lateral foi estimulado após a secção do tronco principal e todos os feixes musculares dos pilares sempre se contraíam do lado ipsilateral do hiato esofágico, independente de anatomicamente constituírem parte do pilar direito ou esquerdo. $\mathrm{Ne}$ nhuma contração contralateral foi observada. Para esse autor, o ramo póstero- 
lateral é mais espesso, formando um ramo distinto quase exclusivamente para a crura. $\mathrm{O}$ autor secciona o nervo frênico esquerdo de coelho e, 2 meses depois, observa que a metade esquerda do diafragma está menor, frouxa e adelgaçada. Os cordões ligamentosos brancos contrastam marcadamente com o lado direito normal, vermelho e firme. Todas as fibras crurais à esquerda do hiato estão atróficas, pálidas e semelhantes à borracha, parecidas muito intimamente com as fibras musculares dos arcos lombares e do diafragma periférico.

CONDE (1957), em pesquisa sobre a distribuição dos nervos frênicos no diafragma de 40 cães, de raça indeterminada, com idades variando de 1 a 10 anos, dos quais 14 fêmeas e 26 machos, concluí que:

1) Os nervos frênicos no Canis familiaris mais freqüentemente terminam por bifurcação, em ramo ventral e tronco dorsolateral $(85,00 \% \pm 5,6$ à direita e $70,00 \%$ $\pm 7,2$ à esquerda).

2) Essa disposição ocorre com maior freqüência tanto no macho como na fêmea.

3) Os nervos frênicos ainda terminam por bifurcação, em ramo dorsal e tronco ventrolateral em $15,00 \% \pm 5,6$ dos casos à direita e em 15,00\% $\pm 5,6$ à esquerda, sem qualquer influência do sexo, estatisticamente significativa.

4) Somente em $15,00 \% \pm 5,6$ dos casos houve típica trifurcação originando os ramos dorsal, lateral e ventral ao mesmo nível da extremidade terminal do tronco do nervo frênico esquerdo. À direita não foi observada esta disposição. 
5) Os troncos dorsolateral e ventrolateral, geralmente curtos, dividem-se nos respectivos ramos dorsal e lateral ou ventral e lateral. Conseqüentemente, resulta no tipo constante de ramificação terminal do nervo frênico, isto é, a disposição correspondente aos 3 ramos diafragmáticos principais: ventral, lateral e dorsal.

6) Em 30,00\% $\pm 2,2$ dos casos havia a presença de um ramo "acessório" originado diretamente de um dos troncos de terminação do nervo frênico, sem interferência estatisticamente significativa do sexo.

7) Os ramos dorsais distribuem-se exclusivamente nas partes lombares correspondentes $(92,50 \% \pm 4,1$ à direita e $85,00 \% \pm 5,6$ à esquerda), sem qualquer influência do sexo. Em 9,50\% $\pm 4,1$ dos casos, tanto à direita quanto à esquerda os ramos dorsais inervam, além das partes lombares, porções das partes costais do mesmo lado. À esquerda, em outros 7,50\% $\pm 4,1$ dos casos, há ainda contribuição do ramo dorsal para a inervação da parte lombar oposta por filete cruzando ventralmente ao hiato esofágico.

8) Os ramos laterais inervam unicamente os feixes musculares costais (dorsais) correspondentes em $95,00 \% \pm 3,4$ dos casos à direita e em $92,50 \% \pm 4,1$ à esquerda, sem interferência do fator sexo.

9) Os ramos laterais distribuem-se nos feixes costais (dorsais) e em pequenas porções lombares dos lados correspondentes em $5,00 \% \pm 3,4$ dos casos à direita e $7,50 \% \pm 4,1$ à esquerda.

10) Os ramos ventrais distribuem-se exclusivamente nos feixes costais do folíolo ventral do centro tendíneo e nas partes esternais em 97,50\% $\pm 2,4$ dos casos à direita e em 95,00\% $\pm 3,4$ à esquerda, não havendo influência do sexo. Rara- 
mente o ramo ventral de um lado contribui também na inervação dos feixes esternais controlaterais $(2,50 \% \pm 2,4$ dos casos possivelmente do lado direito e $5,00 \% \pm 3,4$ do lado esquerdo).

11) Conexões ("anastomoses") entre os ramos diafragmáticos principais do nervo frênico, aparecem com relativa freqüência quer entre ramos do mesmo lado $(10,00 \% \pm 4,7$ à esquerda e $7,50 \% \pm 4,1$ à direita entre os ramos dorsais e laterais) quer entre ramos controlaterais $(5,00 \% \pm 3,4$, dos quais $2,50 \% \pm 2,4$ entre os ramos dorsais e 2,50\% $\pm 2,4$ entre os ramos ventrais).

12) Considerando as várias modalidades de distribuição dos ramos diafragmáticos dos nervos frênicos observados nos exemplares estudados, notase que em 14 casos sobre 40 , ou seja, $35,00 \% \pm 7,5$, um mesmo ramo inerva mais de uma das partes do diafragma, uni ou bilateralmente. Conseqüentemente, apenas em 26 sobre 40 casos $(65,00 \% \pm 7,5)$ encontra-se a disposição geralmente considerada como típica ou constante, isto é, os ramos dorsal, lateral e ventral limitando-se a inervar exclusivamente as partes homolaterais correspondentes do diafragma, bilateralmente.

CONDE (1959), ao examinar com dados experimentais a distribuição dos nervos frênicos no diafragma de 60 suínos (Sus scrofa domesticus) de raça não definida, com idades variando de 13 a 18 meses, apresenta o seguinte relato:

1) Os nervos frênicos em Sus scrofa domesticus terminam mais freqüentemente, à direita e à esquerda, em ramo dorsal e tronco ventrolateral $(95,00 \% \pm 2,8$ à direita e 96,60\% $\pm 2,3$ à esquerda). 
2) A terminação do nervo frênico em típica trifurcação, originando-se os ramos dorsal, lateral e ventral num mesmo nível do tronco do nervo frênico, foi encontrada raramente $(5,00 \% \pm 2,8$ à direita e $1,60 \% \pm 1,6$ à esquerda $)$.

3) A divisão terminal dos nervos frênicos apresenta uma igual disposição bilateral na quase totalidade dos casos (56/60). Somente em 4/60 casos houve assimetria de divisão.

4) As modalidades de divisão terminal dos nervos frênicos distribuíram-se igualmente sem influência estatisticamente significativa do sexo.

5) No Sus scrofa domesticus, como já foi observado em outras espécies, os troncos dorso-lateral e ventrolateral dividem-se, após curto trajeto, nos respectivos ramos dorsal e lateral ou ventral e lateral.

6) É muito raro o aparecimento de um ramo acessório independente originado de um dos troncos (dorsolateral ou ventrolateral).

7) A distribuição dos ramos terminais dorsais dos nervos frênicos limita-se às partes lombares dos lados correspondentes na maioria dos casos $(91,60 \% \pm 6,4$ à direita e $73,30 \% \pm 5,7$ à esquerda). Freqüentemente (33,30\% $\pm 6,1$ dos casos) os ramos dorsais inervam, também, uma porção da parte lombar oposta $(26,60 \%$ $\pm 5,7$ à esquerda e $6,60 \% \pm 3,2$ à direita). Em 1,60\% $\pm 1,6$ o ramo dorsal direito inerva a parte lombar e parte esternal do mesmo lado.

8) Os ramos terminais laterais inervam exclusivamente os feixes musculares costais (dorsais) como disposição habitual (100,00\% à direita e 95,00\% $\pm 2,8$ à esquerda) sem diferença estatisticamente significativa do sexo. É rara a contri- 
buição do ramo lateral para a inervação dos feixes musculares lombares $(5,00 \%$ $\pm 2,8$ do total de casos à esquerda).

9) Os ramos terminais ventrais têm sob sua dependência os feixes musculares costais ventrais e as partes esternais correspondentes $(95,00 \% \pm 2,8$ à esquerda e 100,00\% à direita) sem interferência estatisticamente significativa do sexo. Raramente o ramo ventral de um lado interfere na inervação de feixes musculares contralaterais, cruzando a linha mediana $(3,30 \% \pm 2,3$ dos casos à esquerda).

10) Uniões ou conexões ("anastomoses") entre os ramos terminais são raras no mesmo lado $(3,30 \% \pm 2,3)$ e relativamente freqüentes entre os ramos contralaterais $(20,00 \% \pm 5,1$ dos casos).

11) A distribuição dos nervos frênicos foi simétrica em $36 / 60(60,00 \% \pm 6,3)$ casos e assimétrica em $24 / 60(40,00 \% \pm 6,3)$.

12) Em 11 casos entre os 30 experimentais, foi pela dissecação, após estimulação, evidenciado um filete do ramo dorsal esquerdo cruzando a linha mediana. Em 9 deles, houve resposta ao estímulo, com contração de feixes musculares lombares heterolaterais justo-esofágicos.

13) O estímulo aplicado ao tronco ou ramo dorsal direito foi, nos 30 casos, sempre negativo quanto à contração de feixes musculares heterolaterais.

14) A demonstração de uma inervação motora heterolateral particularmente ao nível do complexo pars lumbalis do diafragma suscita o problema da conceituação de hemidiafragma nos seus aspectos anatômico e funcional. 
ROSENBLUETH et al. (1961), trabalhando mediante estimulação, com cão, coelho, macaco e principalmente com gato, indicam que o suprimento motor respiratório do diafragma é duplo. Em adição aos motoneurônios dos segmentos espinhais C4 a C7, cujos axônios juntam-se no nervo frênico, existem motoneurônios torácicos (T5 a T13), os quais recebem impulsos do centro respiratório e cujos axônios inervam o diafragma. As observações sobre a inervação motora pelos nervos intercostais indicam que há um suprimento motor do diafragma que não está diretamente conectado ao centro respiratório. $\mathrm{O}$ diafragma não é exclusivamente um músculo respiratório; ele se contrai durante algumas ações não respiratórias: tosse, vômito, defecação, parto, etc. Os resultados sugerem que os nervos intercostais, e especialmente do $7^{\circ}$ ao $9^{\circ}$ são importantes vias eferentes para algumas destas ações ou reflexos. Em gatos, cães, coelhos e macacos, a secção dos 2 nervos frênicos no tórax não conduz a uma paralisia do diafragma; movimentos inspiratório e expiratório podem ser registrados. As fibras motoras correspondentes partem da medula espinhal através das raízes ventrais de T5 a T13. O diafragma é inervado pelos nervos intercostais (4 ao 9 ), principalmente pelo $8^{\circ}$. Essas fibras motoras não fazem parte da atividade respiratória, mas das respostas reflexas. O controle espinhal do diafragma inclui, deste modo, 3 conjuntos de fibras motoras. Dois deles são respiratórios: C4 a C7 (os frênicos) e T5 a T13 (a via respiratória acessória). terceiro (T4 a T9) está envolvido em reflexos espinhais e com os nervos intercostais correspondentes.

SANT'AMBROGIO et al. (1963) estudam a inervação motora segmentar das partes costal e vertebral do diafragma de gato, através de eletromiografia. Descrevem que, após sucessivas secções unilaterais das raízes cervicais, a região costal do correpondente hemidiafragma é inervada parcialmente por C4 e principalmente por C5, enquanto a região vertebral é inervada parcialmente 
por C5 e principalmente por C6. Somente em 2 gatos não houve mudança na atividade após secção da $4^{\mathrm{a}}$ raiz cervical (muito freqüentemente o nervo frênico do gato é formado unicamente de C5 e C6 segundo REIGHARD e JENNINGS (1957).

Após secção unilateral de C4, C5 e C6 do lado direito ou esquerdo, não puderam detectar atividade elétrica no hemidiafragma correspondente desde a região vertebral até a esternal. Estes resultados oferecem uma demonstração funcional de que o diafragma, quanto à respiração, é dominado por única inervação motora, dos segmentos espinhais cervicais que formam o nervo frênico.

WILSON (1970) realiza secção unilateral do nervo frênico em 12 gatos e observa histologicamente, após trinta dias, o tronco nervoso periférico ao local da lesão. Nota uma degeneração incompleta das fibras mielinizadas (coloração de ósmio) e persistência de axônios (impregnação argêntica). Estudos concomitantes com o plexo diafragmático, em 6 animais, mostram persistência de algumas fibras nervosas nas zonas crurais e posterolateral no lado da secção, enquanto um número comparável de fibras degeneradas estava presente na zona crural contralateral. A frenicotomia bilateral em um animal mostra persistência de fibras nas zonas crurais e posterolaterais direita e esquerda. Estes achados levantam a possibilidade que fibras acessórias juntem-se ao nervo frênico no terço periférico do seu curso.

DIAS et al. (1974) desenvolvem estudo da origem do nervo frênico em 30 cães (Canis familiaris) de diferentes idades, 18 machos e 12 fêmeas, de raças não definidas, procedentes do canil da Faculdade de Ciências Médicas e Biológicas de Botucatu, valendo-se de fixação das peças em solução de formol a 10\% e dissecação. Caracterizam 4 grupos, de acordo com o comportamento das 
raízes nervosas e os níveis de junção dos filetes nervosos formadores do nervo em apreço, ou seja:

Grupo I-em 1,66\% dos casos, o nervo frênico é formado por 2 filetes nervosos oriundos das raízes de C4 e C5, que se juntam ao nível de C6;

Grupo II - em 70,00\% das peças, o nervo frênico origina-se das raízes de C5 e $\mathrm{C} 6$, podendo os filetes unirem-se ao nível das raízes de $\mathrm{C} 7, \mathrm{C} 8$, da $1^{1^{a}}$ costela e da raiz de $T 1$;

Grupo III -em 1,66\% das observações, o referido nervo acha-se constituído por um filete da raiz de $\mathrm{C} 4$, um da raiz de $\mathrm{C} 5$ e 2 da raiz de $\mathrm{C} 6$; os mais craniais unindo-se à altura da raiz de $\mathrm{C} 6$ e o caudal ao nível de $\mathrm{T} 1$;

Grupo IV - em 26,66\% das oportunidades, o nervo frênico origina-se de filetes das raízes de $\mathrm{C} 5, \mathrm{C} 6$ e $\mathrm{C} 7$, que se juntam, segundo 11 diferentes comportamentos, ao nível desde $\mathrm{C} 8$ até a $2^{\mathrm{a}}$ costela.

TAMEGA et al. (1975) descrevem a origem do nervo frênico de 28 gatos, de diferentes idades, 18 machos e 10 fêmeas e de raças não definidas, concluindo que:

1) O nervo frênico do gato origina-se por um filete nervoso emitido das raízes de C5 e $\mathrm{C} 6$ em $98,21 \%$ dos casos.

2) Somente em um antímero, ou seja, 1,79\% das observações, o nervo frênico recebe contribuição das raízes de C4, C5, e C6. 
3) Quanto ao nível de união dos filetes nervosos formadores dos nervos frênicos observa-se que os filetes nervosos oriundos de C5 e C6 unem-se em 66,07\% dos casos na região cervical.

4) Em $32,14 \%$ dos antímeros a união ocorre dentro da cavidade torácica.

5) Quando o nervo frênico origina-se por filetes nervosos provenientes de C4, C5 e C6, a união daqueles de C4 e C5 ocorre na região cervical, entre a $5^{a}$ e $6^{a}$ vértebras cervicais, enquanto que a contribuição de C6 é incorporada ao nervo frênico dentro da cavidade torácica, ao nível da $1^{\underline{a}}$ vértebra torácica.

6) A união dos filetes nervosos das raízes $\mathrm{C} 5$ e $\mathrm{C} 6$, na região cervical se faz em 3 arranjos: entre a $6^{\underline{a}}$ e a $7^{\text {a }}$ vértebras cervicais $(27,28 \%)$, ao nível da $7^{\text {a }}$ vértebra cervical $(9,09 \%)$ e entre a $7^{\mathrm{a}}$ vértebra cervical e a $1^{\underline{1}}$ vértebra torácica $(32,72 \%)$.

7) Na cavidade torácica, a união dos filetes nervosos das raízes de C5 e C6 ocorre em 2 níveis: entre a $1^{\mathrm{a}}$ e a $2^{\mathrm{a}}$ vértebras torácicas $(27,28 \%)$ e ainda entre a $2^{\underline{a}}$ e $3^{\underline{a}}$ vértebras torácicas $(3,63 \%)$.

8) As secções e estimulações do nervo frênico no gato devem ser realizadas na cavidade torácica.

SILVA et al. (1979), do estudo da divisão terminal e distribuição dos ramos dos nervos frênicos em 30 diafragmas, pertencentes a gambás adultos, 19 machos e 11 fêmeas, julgam poder chegar às seguintes conclusões:

1) Os nervos frênicos terminam à direita $(86,70 \%)$ e à esquerda $(90,00 \%)$, em tronco dorsolateral e ramo ventral. 
2) Os nervos frênicos terminam à direita $(6,70 \%)$ em tronco ventrolateral e ramo dorsal.

3) Os nervos frênicos terminam à direita $(6,70 \%)$ e à esquerda $(6,70 \%)$, trifurcando-se.

4) Os nervos frênicos terminam à esquerda $(3,30 \%)$ em tronco ventrodorsal e ramo lateral.

5) Os nervos frênicos terminam bilateralmente $(70,00 \%)$ em tronco dorsolateral e ramo ventral.

6) Os ramos dorsais dos nervos frênicos inervam à direita (66,70\%) e à esquerda $(50,00 \%)$ a pars lumbalis e as porções dorsal e lateral da pars costalis; à direita $(33,30 \%)$ e à esquerda $(50,00 \%)$, eles dirigem-se apenas à pars lumbalis.

7) Os ramos laterais dos nervos frênicos inervam à direita (93,30\%) e à esquerda $(90,00 \%)$ somente as porções dorsal e lateral da pars costalis; à direita $(3,30 \%)$ e à esquerda (10,00\%), além destas porções, também a pars lumbalis é por eles inervada; apenas á direita (3,30\%), o ramo lateral destina-se a toda a pars costalis.

8) Os ramos ventrais dos nervos frênicos à direita $(100,00 \%)$ e à esquerda $(100,00 \%)$ inervam sempre a porção ventral da pars costalis e da pars sternalis.

9) Existem anastomoses nervosas, homolaterais, entre o ramo dorsal e o ramo lateral, à direita (3,30\%) e à esquerda (16,70\%); entre o ramo lateral e o ramo 
ventral, à direita $(3,30 \%)$; entre o tronco dorsolateral e o ramo dorsal à direita $(3,30 \%)$ e à esquerda $(3,30 \%)$.

10) Na sistematização dos nervos frênicos não foram registradas diferenças estatisticamente significativas, quando confrontados os sexos.

OLIVEIRA DAYOUB et al. (1981) estudam a origem e constituição do nervo frênico em 30 coelhos, 15 fêmeas e 15 machos, da raça Norfolk - 2000. Descrevem a origem deste nervo estabelecendo 4 tipos de emergência: tipo I: C4, C5, C6 em 40 antímeros (66,66\%), sendo 21 (35,00\%) direito e em 19 (31,66\%) esquerdo; tipo II: C4, C5, C6, C7 em 11 antímeros (18,33\%), sendo 5 (8,33\%) direito e 6 (10,00\%) esquerdo; tipo III: C5, C6, C7 em 5 antímeros (8,33\%), sendo 3 (5,00\%) direito e 2 (3,33\%) esquerdo; tipo IV: C5, C6 em 4 antímeros (6,66\%), sendo 1 $(1,66 \%)$ direito e $3(5,00 \%)$ esquerdo. Simetria bilateral ocorre principalmente quando as raízes formadoras do nervo, advém de C4, C5 e C6. Das raízes formadoras do nervo frênico em coelho a principal contribuição provém de C5 em $100,00 \%$ dos casos.

DE TROYER et al. (1981) realizam estimulação da parte costal do diafragma e notam que aumentam as dimensões da porção baixa da caixa torácica, enquanto a estimulação da parte crural diminui as dimensões da mesma. Concluem que o diafragma consiste de 2 músculos que agem diferentemente sobre a caixa torácica. O diafragma costal está em série com os músculos intercostais e músculo acessório da inspiração, equanto o diafragma crural está em paralelo. $O$ modelo do diafragma como 2 músculos separados, um em série, o outro em paralelo com a caixa torácica, tem um claro suporte de ordem anatômica e também uma explicação embriológica. Essas duas partes do diafragma também diferem uma da outra em termos da composição de suas fibras (RILEY et al., 
1979) e de suas raízes nervosas (SANT'AMBROGIO, 1963). Os autores, por fim, admitem que as partes costal e crural têm ações diferentes sobre a parede torácica.

FERREIRA et al. (1981) pesquisam a distribuição dos nervos frênicos em 10 diafragmas do ratão do banhado, 8 machos e 2 fêmeas, adultos, e chegam as seguintes conclusões:

1) Os nervos frênicos do ratão do banhado resolvem-se no ramo ventral e tronco dorsolateral 4 vezes $(40,00 \%)$ em ambos os lados, ramo dorsal e tronco ventrolateral 4 vezes $(40,00 \%)$ à direita e 5 vezes $(50,00 \%)$ à esquerda.

2) Apenas 1 vez (10,00\%) em cada antímero os nervos frênicos trifurcam-se.

3) Os nervos frênicos mostram em 3 casos $(30,00 \%)$ simetria bilateral na sua disposição final.

4) Evidenciam, ainda, filetes nervosos que provenientes dos ramos principais, dirigem-se à porção tendínea do músculo ou à região heteróloga.

LONGO BULL et al. (1981) realizam pesquisa sobre a inervação dos pilares pelos nervos frênicos no coelho, 20 machos e 20 fêmeas e observam que o pilar direito é inervado pelo ramo dorso lateral em 14 animais; pelo dorso lateral posterior, em 11 coelhos; pelos ramos dorso lateral anterior e posterior em 5 peças; pelo ramo dorsal (4); ramo posterior medial (4); dorso lateral e dorso lateral posterior (1) e ramos dorsal, dorso lateral posterior e lateral posterior medial (1). $O$ pilar esquerdo é inervado pelo ramo dorso lateral posterior (15 animais); ramo dorso lateral (14); ramo dorsal (5); ramos dorso lateral anterior e posterior (1); 
ramo dorso lateral anterior (1); ramo dorso lateral medial (1); ramos dorso lateral, dorso medial anterior e dorso medial posterior (1 animal). Evidenciam ainda que o pilar esquerdo apresenta maior número de fibras nervosas quando comparado ao direito.

SALGADO et al. (1981) estudam a origem e distribuição do nervo frênico em 20 cobaias (Cavia porcellus, L. 1756) sendo 10 machos e 10 fêmeas e relatam que o nervo frênico, nessa espécie, origina-se do quarto ao sétimo nervos cervicais, reconhecendo 4 tipos de origem. Informam, ainda que o nervo frênico em cobaia tem de 3 a 4 raízes. No concernente à distribuição no diafragma, os autores observam, preliminarmente, que o aludido nervo tem, basicamente, três ramos: ventral, lateral e dorsal, em ambos os lados. Também observam simetria bilateral, terminal, do nervo frênico em cobaia.

SANTIAGO (1982), examinando a inervação do diafragma em 30 equinos da raça Puro Sangue Inglês, 15 machos e 15 fêmeas, conclui em seu trabalho de mestrado que:

1) Os nervos frênicos terminam em ramo ventral e tronco dorsolateral à direita $(96,70 \%)$ e à esquerda $(26,70 \%)$ ou em ramo dorsal e tronco ventrolateral à esquerda $(66,70 \%)$ e à direita $(33,30 \%)$, encontrando- se ainda, trifurcação em ramos dorsal, lateral e ventral à esquerda (6,60\%).

2) Os nervos frênicos direito e esquerdo comportam-se simetricamente em ramo ventral e tronco dorsolateral $(26,70 \%)$ e, em ramo dorsal e tronco ventrolateral $(3,30 \%)$. 
3) Os ramos dorsais dos nervos frênicos inervam, à esquerda (86,60\%) e à direita $(83,30 \%)$ a parte lombar do mesmo lado; fornecem filetes nervosos ao centro tendíneo do diafragma à direita $(6,60 \%)$ e à esquerda $(6,60 \%)$; emitem filetes ao folíolo dorsal à direita (6,60\%); à parede da veia cava caudal à esquerda $(6,60 \%)$; e, em apenas uma oportunidade, enviam ramos acessórios à porção lombar direita $(3,30 \%)$.

4) Os ramos laterais dos nervos frênicos inervam à esquerda $(90,00 \%)$ e à direita $(56,60 \%)$ a parte costal, mais precisamente, as porções dorsal e lateral do órgão; à direita (23,30\%) emitem filetes à porção lombar; enviam filetes ao folíolo dorsal à direita $(20,00 \%)$ e à esquerda $(3,30 \%)$; e, dirigem-se à porção ventral da parte costal à esquerda (6,60\%).

5) Os ramos ventrais dos nervos frênicos inervam à esquerda ( $86,60 \%)$ e à direita $(76,60 \%)$ a porção ventral da parte costal e a parte esternal do mesmo lado; enviam ramos ao folíolo ventral à direita $(6,60 \%)$ e à esquerda (6,60\%); atravessam o folíolo ventral sendo o responsável pela inervação da parte esternal heterônima à esquerda (3,30\%); inervam somente a parte esternal do mesmo lado à esquerda (3,30\%); inervam somente a porção ventral da parte costal à direita $(3,30 \%)$; constituem pequeno tronco que se desdobra em dois filetes, um à porção ventral da parte costal e outro à parte esternal, à direita (3,30\%); emitem ramo ao folíolo dorsal, à direita (3,30\%); enviam filete à parede da veia cava caudal, à direita $(3,30 \%)$ e um ramo que se endereça ao centro tendíneo do diafragma, à direita $(3,30 \%)$.

6) Conexões ("anastomoses") homolaterais foram vistas à direita $(40,00 \%)$ e à esquerda $(3,30 \%)$, entre os filetes: dos ramos dorsal direito e lateral direito $(30,00 \%)$, do ramo dorsal direito $(3,30 \%)$, do ramo lateral direito $(3,30 \%)$, do 
ramo ventral direito $(3,30 \%)$ e dos ramos dorsal esquerdo e lateral esquerdo $(3,30 \%)$.

7) A análise estatística não apresenta diferença significante, ao nível de 5,00\%, no tocante às várias modalidades de inervação do diafragma, quando confrontados os sexos.

MIGLINO et al. (1986) estudam a ramificação e distribuição dos nervos frênicos de 4 tamanduás bandeira, 3 machos e 1 fêmea adultos, e estabelecem as seguintes conclusões:

1) Os nervos frênicos cedem ramo dorsal e tronco lateroventral, 2 vezes à direita e 1 vez à esquerda, podendo ainda apresentar disposição bifurcada, ou seja, ramo ventral e tronco laterodorsal 2 vezes à direita e 3 vezes à esquerda.

2) Analisados em conjunto os nervos frênicos mostram arranjo simétrico em 3 preparações.

3) Os nervos ao atingirem o diafragma pela face torácica penetram no centro tendíneo do músculo e ramificam-se sob o peritônio, ou seja, no espaço subperitoneal, fato inusitado segundo os autores.

4) A disposição das fibras musculares que compõem a pars muscularis do diafragma caracteriza-se por apresentar arranjo próprio, ou seja, contínuo, não permitindo que se faça uma perfeita delimitação entre as partes costais e lombares. Além disso, a pars muscularis é bastante desenvolvida o que torna o centro frênico deste órgão muito reduzido com o formato de uma foice. 
SANTIAGO (1986), continuando suas pesquisas, observa a ramificação e distribuição dos nervos frênicos em 50 diafragmas de equinos sem raça definida, sendo 25 machos e 25 fêmeas, jovens e adultos e apresenta-nos como conclusões de sua tese de doutorado os seguintes aspectos:

1) Os nervos frênicos nos equinos sem raça definida, fornecem o ramo ventral e tronco laterodorsal 42 vezes (84,00\%) à direita e 5 vezes (10,00\%) à esquerda, o ramo dorsal e tronco lateroventral 40 vezes $(80,00 \%)$ à esquerda e 2 vezes (4,00\%) à direita, encontrando-se ainda origem simultânea dos ramos dorsal, lateral e ventral 6 vezes (12,00\%) à direita e 5 vezes (10,00\%) à esquerda.

2) Os nervos frênicos direito e esquerdo comportam-se simetricamente 9 vezes $(18,00 \%)$ quando fornecem tronco laterodorsal e ramo ventral 5 vezes $(10,00 \%)$, ramo dorsal e tronco lateroventral 2 vezes $(4,00 \%)$, e simultaneamente os ramos dorsais, laterais e ventrais, 2 vezes $(4,00 \%)$.

3) Os ramos dorsais dos nervos frênicos em todas as preparações, tanto à direita como à esquerda distribuem-se na parte lombar (pilares medial e lateral) do lado correspondente, fornecendo ainda o ramo dorsal direito para o folíolo dorsal direito, um filete nervoso 10 vezes (20,00\%), dois filetes nervosos 1 vez $(2,00 \%)$ e para o centro tendíneo um filete nervoso $1 \mathrm{vez}(2,00 \%)$, cedendo ainda o ramo dorsal esquerdo em todos os casos (100,00\%) um filete nervoso para o pilar medial direito, para o folíolo dorsal esquerdo um filete nervoso 3 vezes $(6,00 \%)$, dois filetes nervosos 3 vezes $(6,00 \%)$, e para o centro tendíneo um filete nervoso 3 vezes $(6,00 \%)$, dois filetes nervosos 2 vezes $(4,00 \%)$ e quatro filetes nervosos, 1 vez $(2,00 \%)$. 
4) Os ramos laterais dos nervos frênicos em todas as preparações tanto à direita como à esquerda, distribuem-se na parte costal mais exatamente na região laterodorsal do lado correspondente, fornecendo ainda o ramo lateral direito para o folíolo dorsal direito um filete nervoso 6 vezes (12,00\%), dois filetes nervosos 3 vezes $(6,00 \%)$, três filetes nervosos 1 vez $(2,00 \%)$ e um filete nervoso para a parte lombar direita mais exatamente para o pilar lateral direito, 2 vezes $(4,00 \%)$, cedendo o ramo lateral esquerdo para o folíolo dorsal esquerdo um filete nervoso 8 vezes $(16,00 \%)$ e dois filetes nervosos 2 vezes $(4,00 \%)$.

5) Os ramos ventrais dos nervos frênicos em todas as preparações, tanto à direita como à esquerda distribuem-se às regiões lateroventrais das partes costal e esternal do lado correspondente, fornecendo ainda, o ramo ventral direito para o centro tendíneo, um filete nervoso 3 vezes (6,00\%), em direção à veia cava caudal um filete nervoso 2 vezes (4,00\%) e para o folíolo ventral direito, um filete nervoso, 1 vez $(2,00 \%)$.

6) Conexões ("anastomoses") homolaterais aparecem 10 vezes (20,00\%) isto é, 6 vezes (12,00\%) à direita e 2 vezes (4,00\%) à esquerda, entre os ramos dorsais e laterais correspondentes, e $1 \mathrm{vez}(2,00 \%)$ entre os ramos dorsal e lateral direito e dorsal e lateral esquerdo, enquanto conexões heterolaterais surgem apenas 1 vez $(2,00 \%)$ entre os ramos dorsais direito e esquerdo.

7) A análise estatística não revelou diferenças significantes, quanto ao sexo para $a=5,00 \%$, quando confrontadas em eqüinos sem raça definida as diferentes modalidades de ramificação dos nervos frênicos, o mesmo ocorrendo quando comparados os resultados obtidos nessa pesquisa com os registrados para os eqüinos Puro Sangue Inglês. 
SOUZA et al. (1987), após dissecação de 40 diafragmas de suínos (Sus scrofa domesticus) da raça Landrace, adultos, 20 machos e 20 fêmeas, verificam que:

1) Os nervos frênicos, mais freqüentemente $(80,00 \%$ à direita e $87,50 \%$ à esquerda) cedem ramo dorsal e tronco ventrolateral.

2) Em um menor número de preparações (12,50\% à direita e 7,50\% à esquerda) os nervos frênicos fornecem uma típica trifurcação, resultando nos ramos dorsal, lateral e ventral.

3) A divisão em ramo ventral e tronco dorsolateral é também pouco freqüente (7,50\% à direita e 5,00\% à esquerda).

4) Os nervos frênicos dividem-se em ramo dorsal e tronco ventrolateral, à direita e à esquerda simultaneamente em $72,50 \%$ das preparações.

5) O ramo dorsal dos nervos frênicos inerva apenas a porção lombar correspondente $(90,00 \%$ à direita e $65,00 \%$ à esquerda).

6) O ramo lateral dos nervos frênicos destina-se somente à parte costal correspondente $(60,00 \%$ à direita e $55,00 \%$ à esquerda).

7) O ramo ventral dos nervos frênicos inerva exclusivamente a porção ventral da parte costal e a parte esternal (30,00\% à direita e $75,00 \%$ à esquerda).

8) Conexões ("anastomoses") entre filetes dos ramos dorsais direito e esquerdo são registradas em $15,00 \%$ das peças, por meio de contingentes nervosos que cruzam ventralmente ao hiato esofágico. 
AMORIM JÚNIOR (1988), mediante fixação e dissecação examina, em seu trabalho de dissertação de mestrado, 30 diafragmas de jumentos nordestinos (Asinus asinus, GRAY, 1824, ex. FRITSH, 1775) com o objetivo de conhecer a ramificação e a distribuição dos nervos frênicos direito e esquerdo e observa que:

1) Os nervos frênicos resolvem-se mais freqüentemente em tronco lombocostal e ramo esternal, tanto à direita $(76,70 \%)$ quanto à esquerda $(53,30 \%)$, com disposição simétrica em parte dos casos $(43,30 \%)$.

2) Os ramos lombares destinam-se aos pilares correspondentes (pars lumbalis) cedendo ainda, o da direita, filete nervoso ao pilar medial esquerdo $(3,30 \%)$, folíolo dorsal direito $(6,70 \%)$ e folíolo ventral $(3,30 \%)$ e, o da esquerda, filete nervoso ao pilar medial direito (53,30\%), folíolo dorsal esquerdo (13,30\%) ou folíolo ventral $(6,70 \%)$.

3) Os ramos costais distribuem-se à região dorsal da pars costalis do lado correspondente tanto à direita quanto à esquerda e ainda, à região ventral (3,30\%) à direita, ao folíolo dorsal direito $(3,30 \%)$ e, à esquerda, ao folíolo dorsal esquerdo $(10,00 \%)$.

4) Os ramos esternais distribuem-se, do mesmo lado, à pars sternalis e região ventral da pars costalis emitindo ainda, à direita, filete para a veia cava caudal $(3,30 \%)$ ou para o folíolo ventral $(3,30 \%)$.

MIGLINO et al. (1988) observam a distribuição dos nervos frênicos no diafragma de 15 capivaras adultas (Hydrochoerus hydrochoeris), 12 machos e 3 fêmeas, e apresentam as seguintes considerações: 
1) A divisão dos nervos frênicos na capivara em ramo dorsal e tronco lateroventral, ocorre mais freqüentemente $(73,00 \%)$ com disposição simétrica.

2) A subdivisão dos nervos frênicos é no final, em ramos dorsal, lateral e ventral, que corre em situação subpleural.

3) O ramo dorsal direito, além de inervar a porção lombar ipsilateral do diafragma, supre a veia cava caudal $(40,00 \%)$ juntamente com outras estruturas em percentagens menores.

4) O ramo lateral direito inerva a porção costal ipsilateral (100,00\%) e apenas 1 vez a veia cava caudal.

5) O ramo ventral direito supre as porções costal e esternal ipsilaterais (100,00\%) e também outras estruturas em percentagens menores.

6) Os ramos dorsal e lateral esquerdos inervam as porções lombar (100,0\%) e costal $(100,0 \%)$ ipsilateriais, respectivamente, além de outras estruturas em freqüências menores.

7) O ramo ventral esquerdo supre a porção costal ipsilateral (100,00\%) e simultaneamente as porções esternal e costal esquerdas (93,30\%), além de outras estruturas em porcentagens menores.

8) Em poucos casos existem conexões ipsilateral e contralateral entre os nervos frênicos. 
DALECK (1991), em sua tese de doutorado efetua estudo anatômico, em 13 cães adultos, sem raça definida, buscando encontrar eventuais correspondência das raízes $\mathrm{C} 5, \mathrm{C} 6$ e $\mathrm{C} 7$ (esta inconstante) formadoras do nervo frênico, com seus ramos terminais e, conseqüentemente, estabelecer um conceito de natureza anátomo-funcional, no referente à inervação da pars lumbalis, pars costalis e pars sternalis e conclui que existe correspondência particular entre cada uma das raízes medulares do nervo frênico e seus ramos terminais destinados a territórios específicos da musculatura do diafragma (C5 - ramo esternal - pars sternalis; C6 - ramo costal - pars costalis; C7 - ramo lombar - pars lumbalis, sendo que $\mathrm{C} 6$ supre as correspondências de C 7 , em sua ausência), mostrandose assim, para este caso, válida a "Hipótese de Fürbringer".

AMORIM JUNIOR et al. (1993) estudam a ramificação dos nervos frênicos no diafragma de 15 sagüis (Callithrix jaechus), machos e fêmeas, adultos e encontram as seguintes disposições:

1) Os nervos frênicos dividem-se em tronco lombocostal e ramo esternal 7 vezes $(46,60 \%)$ à direita e 4 vezes $(26,60 \%)$ à esquerda; simultaneamente em 3 ramos: lombar, costal e esternal, 7 vezes (46,60\%) à direita e 6 vezes $(40,00 \%)$ à esquerda, ou mesmo ramo lombar e tronco costoesternal, 1 vez (6,66\%) à direita e 5 vezes $(33,33 \%)$ à esquerda.

2) Analisados em conjunto, os nervos frênicos apresentam disposição simétrica em 8 preparações, 3 das quais (20,00\%) mostram os ramos lombar, costal e esternal emergindo simultaneamente e, em 5 (33,33\%), os nervos frênicos fornecendo um tronco lombocostal e ramo esternal. 
CARVALHO et al. (1993) observam a ramificação e distribuição dos nervos frênicos no diafragma de 17 cutias adultas (Dasyprocta aguti, Rodentia), sendo 10 machos e 7 fêmeas e verificam que:

2) Os nervos frênicos cedem ramo ventral e tronco dorsolateral, 11 vezes (64,70\%) à direita, e 4 vezes (23,50\%) à esquerda, ramo dorsal e tronco ventrolateral 3 vezes $(17,60 \%)$ à direita e 6 vezes $(41,20 \%)$ à esquerda e, simultaneamente os ramos dorsal, lateral e ventral 2 vezes $(11,80 \%)$ à direita e 4 vezes $(23,50 \%)$ à esquerda.

2) Os nervos frênicos direito e esquerdo apresentam arranjos simétricos cedendo ramo dorsal e tronco ventrolateral 2 vezes $(11,80 \%)$ e ramo ventral e tronco dorsolateral 4 vezes $(23,54 \%)$ e $1 \mathrm{vez}(5,90 \%)$ quando os ramos dorsal, lateral e ventral emergem simultaneamente.

3) Os ramos dorsais dos nervos frênicos inervam, sempre, tanto à direita como à esquerda, as correspondentes partes lombares do diafragma, emitindo filetes ao folíolo dorsal 5 vezes $(29,40 \%)$ à direita, 11 vezes $(64,70 \%)$ à esquerda.

4) Os ramos laterais dos nervos frênicos inervam, sempre, tanto à direita como à esquerda, a região laterodorsal da parte costal, emitindo ramo acessório para as partes lombares 3 vezes (17,60\%) à direita e 6 vezes (35,30\%) à esquerda, e 1 vez um filete dos ramos laterais inerva a região do pilar direito.

5) Os ramos ventrais dos nervos frênicos inervam, sempre, tanto à direita como à esquerda, a região lateroventral da parte costal e parte esternal correspondentes. 
MENDONÇA et al. (1993) investigam a distribuição dos nervos frênicos no diafragma de Colomys calosus adultos, de ambos os sexos e verificam que o nervo frênico esquerdo termina em ramo dorsal e tronco ventrolateral em $35,71 \%$ dos casos, e em ramo ventral e tronco dorsolateral em $64,29 \%$ das observações. $O$ nervo frênico direito termina em ramo dorsal e tronco ventro-lateral em $57,14 \%$ das peças, em ramo ventral e tronco dorsolateral em $14,29 \%$ das oportunidades.

MIGLINO et al. (1993) verificam a distribuição dos ramos dos nervos frênicos em 4 diafragmas de cateto (Tayassu tayassu), 2 machos e 2 fêmeas, adultos e descrevem que os nervos frênicos fornecem, ao atingirem o centro tendíneo do diafragma, um ramo dorsal e um tronco lateroventral, à esquerda e à direita (100,00\%). O ramo dorsal, à direita, distribui-se à porção lombar correspondente e à esquerda, além da parte a ele destinada, por meio de delgados filetes, que cruzam ventralmente o hiato esofágico, atinge a porção lombar oposta $(75,00 \%)$. Os ramos lateral e ventral, resultantes da divisão do tronco lateroventral, distribuem-se às partes musculares a eles correspondentes (100,00\%), atingindo, por vezes $(50,00 \%)$ o folíolo dorsal direito da parte tendínea.

MELO et al. (1999), estudando a participação dos nervos intercostais na inervação do diafragma em 31 cães sem raça definida, machos e fêmeas, comentam que a contribuição dos nervos intercostais (do $8^{\circ}$ ao $12^{\circ}$ pares) na inervação do diafragma ocorre em $93,50 \%$ dos casos. Os autores informam que em 1 observação (3,22\%) o $12^{2}$ nervo intercostal esquerdo não é identificado, assim como, em outra oportunidade (3,22\%), o $8^{\circ}$ nervo intercostal direito não inerva o diafragma de cães. 
Material e Método 
Para realização deste trabalho foram utilizados 30 ovinos (Ovis aries - Linnaeus, 1758) da raça Santa Inês, sendo 9 fêmeas e 21 machos, de diferentes idades, procedentes de diversas regiões de criação do Estado da Bahia e principalmente do município de Ipirá e obtidos em frigoríficos do mesmo Estado.

Estes animais, após o abate, foram conduzidos ao Laboratório de Anatomia do Departamento de Anatomia dos Animais Domésticos da Escola de Medicina Veterinária da Universidade Federal da Bahia, onde foram fixados em solução aquosa de formol a $10 \%$.

Para uma melhor abordagem do nervo frênico no que tange à sua origem, procedíamos à abertura da cavidade torácica em ambos os antímeros, mediante remoção de parte do gradil torácico, correspondente ao intervalo entre o $1^{\circ}$ e $7^{\circ}$ pares de costelas.

Uma vez exposta a cavidade torácica e retirados os pulmões, identificávamos em cada antímero, o nervo frênico, acompanhando seu trajeto no sentido cranial, a fim de identificar os ramos ventrais dos nervos espinhais cervicais formadores do mesmo. Tomávamos o cuidado de observar seus locais de origem na região cervical, bem como o local de união dos referidos ramos ventrais dos nervos espinhais cervicais.

Para tanto, procedíamos ao afastamento dos músculos da região, principalmente o músculo escaleno, que representa o ponto de referência efetivo para a visualização dos ramos ventrais dos nervos espinhais cervicais que originam os nervos frênicos. 
Uma vez completada a dissecação da região cervical e posterior identificação dos nervos frênicos e de suas raízes formadoras, seccionávamos a peça, separando o pescoço, do tronco.

Após a evisceração da cavidade abdominal, separávamos o tórax do abdome, reduzindo cada peça à região torácica com pequeno segmento da porção lombar.

Em seguida, acompanhávamos o trajeto dos nervos lombares, observando se algum deles alcançava os pilares do diafragma (pars lumbalis).

Dando prosseguimento, procedíamos à retirada do segmento lombar, seccionando-o junto à inserção lombar do diafragma e às articulações costovertebrais.

Continuando, dissecávamos os espaços intercostais a partir da $8^{\text {a }}$ costela, acompanhando junto à borda caudal o trajeto dos nervos intercostais, verificando se, porventura, algum deles dirigía-se ao diafragma.

Terminada esta etapa, o diafragma com suas inserções costais e esternal era lavado em água corrente e imerso em solução aquosa de formol a 10\%.

Posteriormente, tomávamos o cuidado de, uma vez identificados os nervos frênicos, preservá-los em segmento de aproximadamente $5 \mathrm{~cm}$, ainda quando indivisos no diafragma.

Em seguida, apoiávamos o diafragma em uma base hemiesférica e efetuávamos a dissecação de interesse com auxílio de lupa bi-focal LP23II $(1,8 x-2,3 x)$ e de fino estilete, abordando o músculo por sua face torácica. 
Para a descrição dos resultados (Fig. 1) adotamos da NOMINA ANATOMICA VETERINÁRIA (1994) as expressões pars lumbalis, pars costalis e pars sternalis para designar segmentos da porção carnosa do diafragma cuja inserção faz-se, por ordem, em função dos pilares, das costelas mais respectivas cartilagens e da cartilagem xifóide do esterno. Com base neste procedimento e obedecendo a natural disposição dos ramos terminais dos nervos frênicos nos aludidos segmentos da porção carnosa, decidimos seguir denominação efetuada por AMORIM JÚNIOR (1988) que considera, respectivamente, ramo lombar, ramo costal e ramo esternal e os seus eventuais troncos de origem, de tronco lombocostal e tronco costoesternal.

Convencionamos dividir a pars costalis em duas regiões, dorsal e ventral, tomando-se como limite linha horizontal imaginária tangente à terminação ventral dos pilares do diafragma.

Quanto à porção tendínea do diafragma, nela consideramos três regiões, os folíolos dorsal direito, dorsal esquerdo e ventral, conforme o exposto na Fig. 1.

De outra parte, com vistas à eleição de critério para o estabelecimento de limite entre a pars costalis e a pars sternalis, observamos que a pars sternalis encontra-se separada da pars costalis, a cada lado, por um espaço sem reforço muscular (Fig. 1).

Na sistematização dos ramos do nervo frênico levamos em conta a abrangência das áreas por eles inervadas. Os filetes nervosos originados dos nervos principais somente foram descritos quando se encaminhavam a outras regiões do diafragma que não as de definido endereçamento daqueles ramos. 
Finalmente, ao término de cada preparação registrávamos, sob a forma de desenhos esquemáticos, as raízes cervicais formadoras do nervo frênico, a divisão e a distribuição dos nervos endereçados ao diafragma, fotografando algumas peças para ulterior documentação. Para efeito de melhor visualização, as estruturas nervosas foram, posteriormente à dissecação, destacadas com pintura em amarelo ${ }^{1}$. Alguns dados dos resultados foram tratados estatisticamente. Ressaltamos, entretanto, que a distribuição da variável nas diversas classes apresenta número menor do que o recomendado para o teste do $\mathrm{X}^{2}$, levando à uma possível ocorrência de viés.

${ }^{1}$ Acrilex - São Paulo - SP 


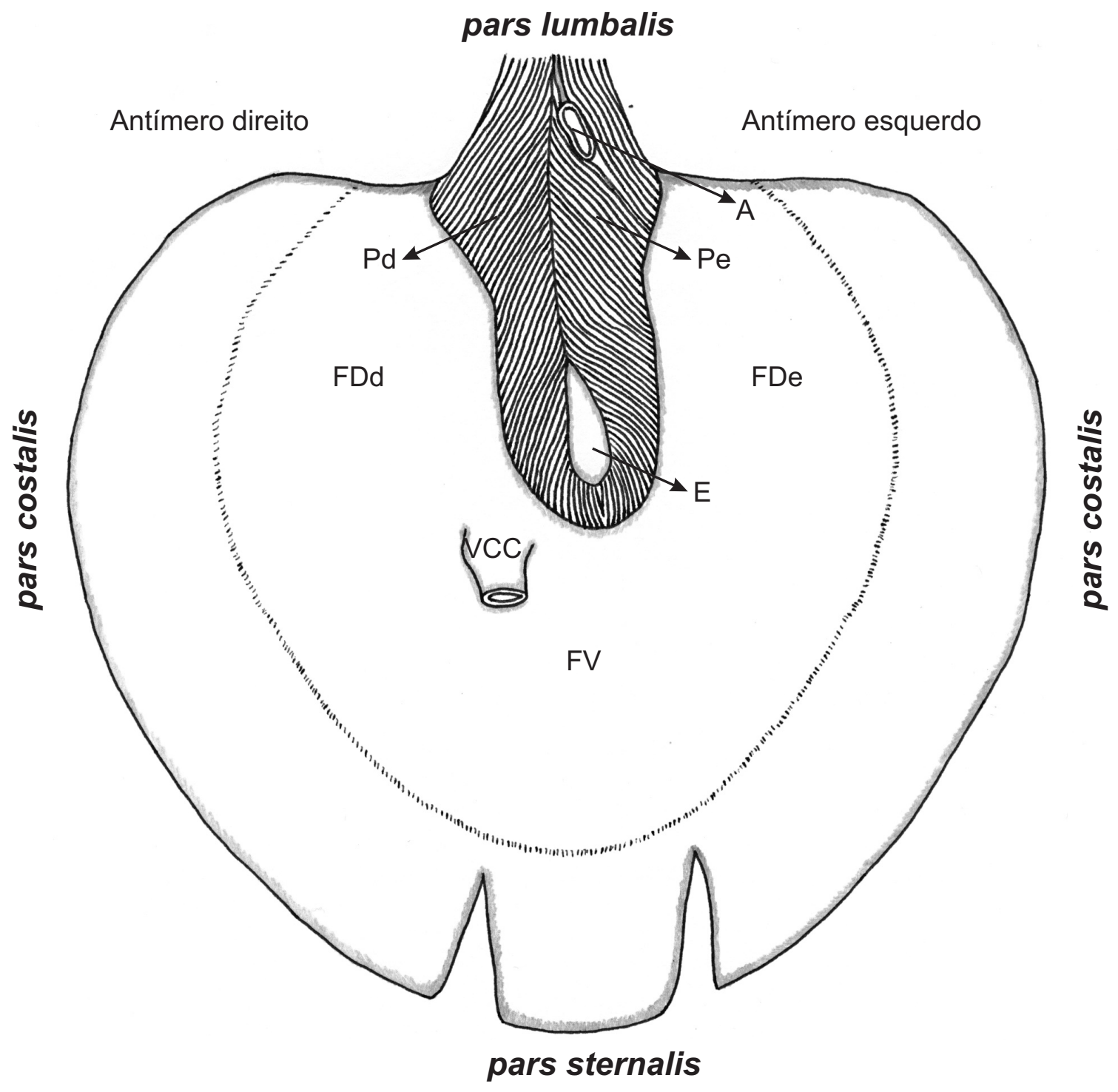

Figura 1 - Representação esquemática de diafragma (face torácica) de ovino da raça Santa Inês.

Pd - Pilar direito

$\mathrm{Pe}$ - Pilar esquerdo

FDd - Folíolo dorsal direito

FDe - Folíolo dorsal esquerdo

FV - Folíolo ventral

A - Hiato aórtico

E - Hiato esofágico

VCC - Veia cava caudal 
Resultados 
Para a descrição dos resultados decorrentes da dissecação de 30 exemplares de ovinos da raça Santa Inês, observamos a origem dos nervos frênicos, sua divisão terminal e distribuição no diafragma, bem como a participação de outros nervos (intercostais e lombares) na inervação do referido músculo.

No tocante à origem dos nervos frênicos abordaremos os níveis de origem e de união dos filetes nervosos formadores destes nervos.

Quanto às observações concernentes à ramificação e distribuição dos nervos frênicos no diafragma, seguiremos a seguinte ordem de apresentação:

- Ramos terminais do nervo frênico direito.

- Ramos terminais do nervo frênico esquerdo.

- Ramos terminais dos nervos frênicos direito e esquerdo, considerados em conjunto.

- Distribuição do ramo lombar do nervo frênico direito.

- Distribuição do ramo lombar do nervo frênico esquerdo

- Distribuição do ramo costal do nervo frênico direito.

- Distribuição do ramo costal do nervo frênico esquerdo.

- Distribuição do ramo esternal do nervo frênico direito.

- Distribuição do ramo esternal do nervo frênico esquerdo. 


\section{1) ORIGEM DOS NERVOS FRÊNICOS}

De modo geral, os nervos frênicos, quando bilateralmente examinados nos ovinos da raça Santa Inês, originam-se por uma, duas ou três raízes. De acordo com o número de raízes formadoras, os nervos frênicos são divididos em tipos: I, II e III, respectivamente.

$\mathrm{Na}$ totalidade dos casos observados as raízes cervicais comportam-se, para a formação dos nervos frênicos, dos seguintes modos (Quadro 1):

a) NERVO FRÊNICO DIREITO

Este nervo, mais freqüentemente, ou seja, 22 vezes $(73,33 \%$ - Obs. $1 \mathrm{M}, 2 \mathrm{M}, 3 \mathrm{~F}$, $4 \mathrm{M}, 5 \mathrm{M}, 6 \mathrm{~F}, 7 \mathrm{~F}, 8 \mathrm{M}, 11 \mathrm{M}, 12 \mathrm{M}, 13 \mathrm{M}, 15 \mathrm{~F}, 18 \mathrm{M}, 19 \mathrm{~F}, 20 \mathrm{M}, 21 \mathrm{~F}, 22 \mathrm{M}, 23 \mathrm{M}, 24 \mathrm{M}$, 26M, 28M e 30M), origina-se por duas raízes (Tipo II) e apresenta arranjos variados, a saber:

- Em 11 oportunidades (36,67\% - Obs. 1M, 2M, 5M, 6F, 7F, 13M, 20M, 22M, 23M, $24 \mathrm{M}$ e $26 \mathrm{M}$ ) as raízes formadoras procedem dos ramos ventrais do $5^{\circ}$ e $6^{\circ}$ nervos espinhais cervicais. Cada nervo espinhal cervical (C5 e C6) contribui com um único filete nervoso (Figs. 2, 25 e 26).

- Em 6 preparações (20,00\% - Obs. 11M, 18M, 19F, 21F, 28M e 30M) surpreendemos o nervo frênico direito originando-se por duas raízes procedentes dos ramos ventrais do $6^{\circ}$ e $7^{\circ}$ nervos espinhais cervicais. Cada nervo espinhal cervical (C6 e C7) contribui com um único filete nervoso (Figs. 3, 27 e 28). 
- Em 4 peças (13,33\% - Obs. 3F, 4M, 8M e 12M) notamos o aludido nervo constituído por duas raízes procedentes dos ramos ventrais do $5^{\circ}$ e $6^{\circ}$ nervos espinhais cervicais, sendo que $\mathrm{C} 6$ contribui com dois filetes nervosos, um deles muito delgado e curto (Figs. 4 e 29).

- Em apenas 1 observação (3,33\% - Obs. 15F) encontramos o nervo frênico direito originando-se por duas raízes procedentes dos ramos ventrais do $6^{\circ} \mathrm{e} 7^{\circ}$ nervos espinhais cervicais. C6 contribui com dois filetes nervosos, sendo um deles muito delgado e curto (Figs. 5 e 30).

Por sua vez, em 8 preparações (26,67\% - Obs. 9M, 10M,14F, 16F, 17F, 25M, 27M e 29M) o nervo frênico direito origina-se por três raízes (Tipo III) e exibe dois arranjos:

- Em 6 oportunidades (20,00\% - Obs. 9M, 10M,14F, 17F, 27M e 29M) as raízes formadoras procedem dos ramos ventrais do $5^{\circ}, 6^{\circ}$ e $7^{\circ}$ nervos espinhais cervicais. Cada nervo espinhal cervical (C5, C6 e C7) contribui com um único filete nervoso (Figs. 6 e 31).

- Em 2 observações (6,67\% - Obs. 16F e 25M) o nervo frênico direito mostra-se procedente dos ramos ventrais do $5^{\circ}, 6^{\circ}$ e $7^{\circ}$ nervos espinhais cervicais, com C6 contribuindo com dois filetes nervosos, sendo um deles muito delgado e curto (Figs. 7 e 32). 
O tipo I (uma raiz) não é encontrado em nenhuma das peças observadas.

Os filetes nervosos formadores do nervo frênico direito unem-se em diferentes níveis após sua origem a partir das respectivas raízes cervicais, apresentando os seguintes comportamentos (Quadro 2):

- Nas preparações em que o nervo frênico direito forma-se a partir de duas raízes, isto é, às custas dos ramos ventrais do $5^{\circ}$ e $6^{\circ}$ ou do $6^{\circ}$ e $7^{\circ}$ nervos espinhais cervicais, cada um contribuindo com um único filete nervoso, a união destes processa-se ao nível da $1^{\text {a }}$ costela, 13 vezes (43,33\% - Obs. 1M, 2M, 5M, 6F, 7F, 11M, 13M, 18M, 20M, 21F, 22M, 23M e 28M - Figs. 25 e 27), em correspondência à articulação entre a $6^{\mathrm{a}}$ e $7^{\mathrm{a}}$ vértebras cervicais, 2 vezes $(6,67 \%$ - Obs. $19 \mathrm{~F} \mathrm{e}$ $30 \mathrm{M}$ - Fig. 28) e em correspondência à articulação entre a $5^{\mathrm{a}}$ e $6^{\mathrm{a}}$ vértebras cervicais, 2 vezes (6,67\% - Obs. 24M e 26M - Fig. 26).

- Naquelas peças em que o nervo frênico direito origina-se de filetes nervosos oriundos dos ramos ventrais do $5^{\circ}$ e $6^{\circ}$ nervos espinhais cervicais, com $C 6$ contribuindo com dois filetes nervosos, a união do curto filete de C6 com o filete maior ocorre em correspondência à articulção entre a $6^{a}$ e $7^{a \underline{a}}$ vértebras cervicais, formando um tronco que recebe o filete procedente do ramo ventral de $\mathrm{C} 5$, ao nível da $1^{\text {a }}$ costela, 4 vezes (13,33\% - Obs. 3F, 4M, 8M e 12M - Fig. 29).

- Do mesmo modo, quando o nervo frênico direito é formado pelos ramos ventrais do $6^{\circ}$ e $7^{\circ}$ nervos espinhais cervicais, com C6 contribuindo com dois filetes nervosos, a união do curto filete de $\mathrm{C} 6$ com o filete procedente de $\mathrm{C} 7$ pro- 
cessa-se em correspondência à articulação entre a $6^{a}$ e $7^{\underline{a}}$ vértebras cervicais, constituindo um tronco que recebe o filete maior oriundo de $\mathrm{C} 6$, ao nível da $1^{\text {a }}$ costela, 1 vez (3,33\% - Obs. 15F - Fig. 30).

- Quando o nervo frênico direito é composto pelos ramos ventrais do $5^{\circ}, 6^{\circ}$ e $7^{\circ}$ nervos espinhais cervicais, cada um contribuindo com um único filete nervoso, a união do ramo ventral de $\mathrm{C} 6$ com o correspondente de $\mathrm{C} 7$, para constituir um tronco ocorre em correspondência à articulação entre a $6^{\underline{a}}$ e $7^{\underline{a}}$ vértebras cervicais, enquanto a união do ramo ventral oriundo de $\mathrm{C} 5$, para compor o nervo frênico direito propriamente dito, processa-se ao nível da $1^{\text {a }}$ costela, 6 vezes (20,00\% - Obs. - 9M, 10M, 14F, 17F, 27M e 29M - Fig. 31).

- Nos casos em que o nervo frênico direito origina-se a partir dos ramos ventrais do $5^{\circ}, 6^{\circ}$ e $7^{\circ}$ nervos espinhais cervicais, com $\mathrm{C} 6$ contribuindo com dois filetes nervosos, a união do curto filete de $\mathrm{C} 6$ com o filete oriundo de $\mathrm{C} 7$ ocorre em correspondência à articulação entre a $6^{\underline{a}}$ e $7^{\mathrm{a}}$ vértebras cervicais; 0 tronco resultante une-se ao filete maior procedente de C6 também em correspondência à articulação entre a $6^{\underline{a}}$ e $7^{\underline{a}}$ vértebras cervicais, enquanto que a contribuição de C5 é incorporada ao nervo frênico direito propriamente dito, ao nível da $1^{1}{ }^{a} \cos -$ tela, 2 vezes (6,67\% - Obs. 16F e 25M - Fig. 32).

- A análise estatística do número de raízes formadoras e do nível de união dessas raízes do nervo frênico direito, conduzida com base no teste de $X^{2}$, não revelou influência do sexo sobre essas variáveis, ou seja, para o número de raízes formadoras o X² é igual a 0,292 e para o nível de união dessas raízes o $X^{2}$ é igual a 1,25. 
b) NERVO FRÊNICO ESQUERDO

Este nervo, na maioria das dissecações, isto é, 18 vezes (59,99\% - Obs. 1M, 2M, 3F, 4M, 5M, 6F, 7F, 8M, 10M, 11M, 12M, 15F, 18M, 20M, 22M, 23M, 24M e $26 \mathrm{M}$ ) origina-se a partir de duas raízes (Tipo II) e apresenta as seguintes variações:

- Em 10 peças (33,34\% - Obs. 1M, 2M, 5M, 6F, 7F, 10M, 20M, 22M, 24M e 26M) as raízes formadoras procedem dos ramos ventrais do $5^{\circ}$ e $6^{\circ}$ nervos espinhais cervicais. Cada nervo espinhal cervical ( $\mathrm{C} 5$ e $\mathrm{C6}$ ) contribui com um único filete nervoso (Figs. 8, 25 e 26).

- Em 4 preparações (13,33\% - Obs. 8M, 11M, 15F e 18M) verificamos o nervo frênico esquerdo originando-se por duas raízes procedentes dos ramos ventrais do $6^{\circ}$ e $7^{\circ}$ nervos espinhais cervicais, sendo que cada nervo espinhal cervical (C6 e C7) contribui com um único filete nervoso (Figs. 9, 27, 28 e 33).

- Em 3 observações (9.99\% - Obs. 3F, 4M e 12M) notamos o aludido nervo constituído por duas raízes procedentes dos ramos ventrais do $5^{\circ} \mathrm{e} 6^{\circ}$ nervos espinhais cervicais, sendo que C6 contribui com dois filetes nervosos (Figs. $10 \mathrm{e}$ 34).

- Em 1 oportunidade (3,33\% - Obs. 23M) observamos o nervo frênico esquerdo composto por duas raízes oriundas dos ramos ventrais do $6^{\circ}$ e $7^{\circ}$ nervos espinhais cervicais, C6 contribuindo com dois filetes nervosos, sendo um muito delgado e curto (Figs. 11 e 30). 
- Por outro lado, em 10 dissecações (33,34\% - Obs. 9M, 13M, 14F, 16F, 17F, $21 \mathrm{~F}, 25 \mathrm{M}, 27 \mathrm{M}, 28 \mathrm{M}$ e $30 \mathrm{M}$ ) o nervo frênico esquerdo origina-se a partir de 3 raízes (Tipo III), isto é, dos filetes nervosos procedentes dos ramos ventrais do $5^{\circ}, 6^{\circ}$ e $7^{\circ}$ nervos espinhais cervicais. Cada nervo espinhal cervical (C5, C6 e C7) contribui com um único filete nervoso (Figs. 12, 31 e 35).

- Em um menor número de preparações, ou seja, 2 vezes (6,67\% - Obs. 19F e 29M) este nervo mostra-se procedente apenas de uma raiz (Tipo I), ou seja, do ramo ventral do $6^{\circ}$ nervo espinhal cervical (Figs. 13 e 36 ).

Quanto aos níveis de união dos filetes nervosos formadores do nervo frênico esquerdo, encontramos várias disposições (Quadro 3):

- Nas oportunidades em que este nervo forma-se a partir de dois filetes nervosos, isto é, dos ramos ventrais do $5^{\circ}$ e $6^{\circ}$ ou do $6^{\circ}$ e $7^{\circ}$ nervos espinhais cervicais, cada um contribuindo com um único filete nervoso, a união destes ocorre ao nível da $1^{\mathrm{a}}$ costela, 10 vezes $(35,71 \%$ - Obs. $1 \mathrm{M}, 2 \mathrm{M}, 5 \mathrm{M}, 6 \mathrm{~F}, 7 \mathrm{~F}, 10 \mathrm{M}, 15 \mathrm{~F}$, 18M, 20M e 22M - Figs. 25 e 27), em correspondência à articulação entre a 6 e $7^{\text {a }}$ vértebras cervicais, 1 vez (3,57\% - Obs. 11M - Fig. 28) e em correspondência à articulação entre a $5^{\mathrm{a}}$ e 6⿳亠丷厂 vértebras cervicais, 3 vezes $(10,71 \%$ - Obs. $8 \mathrm{M}$, $24 \mathrm{M}$ e $26 \mathrm{M}$ - Fig. 26).

- Nas preparações em que o nervo frênico esquerdo é formado pelos ramos ventrais do $5^{\circ}$ e $6^{\circ}$ nervos espinhais cervicais, com $\mathrm{C} 6$ contribuindo com dois filetes nervosos, a união do curto filete de $\mathrm{C} 6 \mathrm{com}$ o filete maior processa-se 
em correspondência à articulação entre a $6^{\underline{a}}$ e $7^{a} \underline{\underline{a}}$ vértebras cervicais, constituindo um tronco que recebe o filete nervoso oriundo do ramo ventral de $\mathrm{C} 5$, ao nível da $1^{\underline{a}}$ costela, 2 vezes (7,14\% - Obs. 3F e 4M - Fig. 29); enquanto em 1 peça (3,57\% - Obs. 12M - Fig. 34) um dos filetes procedente de C6 une-se ao filete oriundo de $C 5$, em correspondência à articulação entre $a 5^{\underline{a}}$ e $6^{\underline{a}}$ vértebras cervicais, enquanto o tronco resultante recebe o outro filete proveniente de $\mathrm{C6}$, ao nível da $1^{1 \mathfrak{a}}$ costela.

- Naquela dissecação em que o nervo frênico esquerdo é composto por filetes nervosos oriundos dos ramos ventrais do $6^{\circ}$ e $7^{\circ}$ nervos espinhais cervicais, com $\mathrm{C} 6$ contribuindo com dois filetes, a união do curto filete de C6 com o filete procedente de $\mathrm{C} 7$ processa-se em correspondência à articulação entre a $6^{\underline{a}} \mathrm{e}$ $7^{\mathrm{a}}$ vértebras cervicais, constituindo um tronco que recebe o filete maior oriundo de C6, ao nível da $1^{a}$ costela, 1 vez (3,57\% - Obs. 23M - Fig. 30)

- Quando o nervo frênico esquerdo é oriundo dos ramos ventrais do $5^{\circ}, 6^{\circ}$ e $7^{\circ}$ nervos espinhais cervicais, cada um contribuindo com um único filete nervoso, a união do ramo ventral de $\mathrm{C} 6$ com o correspondente de $\mathrm{C} 7$, para constituir um tronco, ocorre em correspondência à articulação entre a $6^{\underline{a}}$ e $7^{\mathrm{a}}$ vértebras cervicais, enquanto a união do ramo ventral oriundo de $\mathrm{C} 5$, para compor o nervo frênico esquerdo propriamente dito ocorre ao nível da $1^{1}$ costela, 9 vezes (32,16\% - Obs. 9M, 13M, 14F, 16F, 17F, 21F, 25M, 27M e 30M - Fig. 31)

- Na peça restante, 1 vez (3,57\% - Obs. 28M - Fig. 35 ) o filete nervoso oriundo de C5 une-se ao correspondente de C7, em relação à articulação entre a $5^{a}$ e 
6 ${ }^{\underline{a}}$ vértebras cervicais, constituindo um tronco que recebe a contribuição de C6, ao nível da 1aㅡ costela.

- A análise estatística do número de raízes formadoras e do nível de união dessas raízes do nervo frênico esquerdo, conduzida com base no teste do $X^{2}$, não revelou influência do sexo sobre essas variáveis, com o $X^{2}$ igual a 1,376 para a variável número de raízes formadoras e $X^{2}$ igual a 2,22 para a outra variável (nível de união dessas raízes).

\section{c) FORMAÇÃO DOS NERVOS FRÊNICOS}

Os nervos frênicos, nos ovinos da raça Santa Inês quando bilateralmente analisados, mostram formação simétrica, ou seja, provém de um mesmo número de raízes cervicais em ambos os antímeros, em 19 preparações (63,33\% - Obs. $1 \mathrm{M}, 2 \mathrm{M}, 3 \mathrm{~F}, 4 \mathrm{M}, 5 \mathrm{M}, 6 \mathrm{~F}, 7 \mathrm{~F}, 9 \mathrm{M}, 11 \mathrm{M}, 13 \mathrm{M}, 14 \mathrm{~F}, 17 \mathrm{~F}, 18 \mathrm{M}, 19 \mathrm{~F}, 20 \mathrm{M}, 22 \mathrm{M}, 24 \mathrm{M}$, 26M e 27M) e constituição assimétrica em 11 casos (36,67\%- Obs. 8M, 10M, $12 \mathrm{M}, 15 \mathrm{~F}, 16 \mathrm{~F}, 21 \mathrm{~F}, 23 \mathrm{M}, 25 \mathrm{M}, 28 \mathrm{M}, 29 \mathrm{M}$ e 30M).

Disposição simétrica comprovada pela análise estatística, com base no teste do $X^{2}$ (igual a 10,34) e nível de significância de 5,00\%. Quanto ao nível de união das raízes formadoras dos nervos frênicos, quando confrontados os antímeros, a análise estatística desses dados, também com base no teste do $X^{2}$ (igual a 25,67) revelou significância ao nível de rejeição de 5,00\%, em outras palavras, há uma simetria entre os antímeros, quanto ao nível de união dos filetes formadores dos nervos frênicos direito e esquerdo. 
Nos ovinos da raça Santa Inês, das raízes formadoras dos nervos frênicos, aquela correspondente a C5, quando presente, é a mais longa, sendo a procedente de C6 constante em todas as preparações examinadas, enquanto a raiz oriunda de C7 é a mais curta.

2) RAMOS TERMINAIS DO NERVO FRÊNICO DIREITO (Fig. 37)

a) Em 12 diafragmas (40,00\%), pertencentes a 5 fêmeas e 7 machos (Obs. 13M, 14F, 15F, 16F, 18M,19F, 21F, 22M, 23M, 27M, 28M e 30M), observamos o nervo frênico revolvendo-se em tronco lombocostal e ramo esternal (Fig. 14)

b) Em 10 peças (33,33\%), sendo 3 de fêmeas e 7 de machos (Obs. 3F, 5M, 6F, 7F, 10M, 11M, 24M, 25M, 26M e 29M), verificamos o nervo frênico emitindo os ramos lombar, costal e esternal simultaneamente (Fig. 15)

c) Em 5 preparações (16,67\%), pertinentes a exemplares machos (Obs. 2M, 8M, 9M, 12M e 20M), deparamos com o nervo frênico dividindo-se nos troncos lombocostal e costoesternal (Fig. 16)

d) Em 2 casos (6,67\%), atinentes a 1 fêmea e 1 macho (Obs. 4M, 17F), encontramos o nervo frênico fornecendo o ramo lombar e o tronco costoesternal.

e) Em 1 oportunidade (3,33\%), correspondente a 1 macho (Obs. $1 \mathrm{M})$, surpreendemos o nervo frênico cedendo, ao mesmo tempo, o tronco lombocostal e ramos costal e esternal. 
3) RAMOS TERMINAIS DO NERVO FRÊNICO ESQUERDO (Fig. 37)

a) Em 10 preparações (33,33\%), sendo 5 de fêmeas e 5 de machos (Obs. 3F, $5 \mathrm{M}, 6 \mathrm{~F}, 15 \mathrm{~F}, 16 \mathrm{~F}, 21 \mathrm{~F}, 22 \mathrm{M}, 25 \mathrm{M}, 28 \mathrm{M}$ e 29M), registramos o nervo frênico emitindo os ramos lombar, costal e esternal simultaneamente (Fig. 17)

b) Em 8 peças (26,68\%), pertencentes a 1 fêmea e 7 machos (Obs. 4M, 10M, $11 \mathrm{M}, 13 \mathrm{M}, 17 \mathrm{~F}, 18 \mathrm{M}, 26 \mathrm{M}$ e 30M), observamos o nervo frênico fornecendo $\mathrm{O}$ ramo lombar e tronco costoesternal (Fig. 18)

c) Em 6 dissecações (20,00\%), relativas a 3 fêmeas e 3 machos (Obs. 7F, 14F, 19F, 20M, 24M, e 27M), verificamos o nervo frênico revolvendo-se no tronco lombocostal e ramo esternal (Fig. 19)

d) Em 4 oportunidades (13,33\%), todas correspondentes a machos (Obs. 1M, $9 \mathrm{M}, 12 \mathrm{M}$ e $23 \mathrm{M}$ ), identificamos o nervo frênico cedendo os ramos lombar, costal (em número de dois) e esternal, concomitantemente (Fig. 20)

e) Em 1 caso (3,33\%), pertencente a 1 macho (Obs. $2 \mathrm{M}$ ), observamos o nervo frênico dividindo-se, ao mesmo tempo, nos troncos lombocostal e costoesternal.

f) Em 1 diafragma (3,33\%), atinente a 1 macho (Obs. 8M), encontramos o nervo frênico emitindo os ramos lombar e costal e o tronco costoesternal, simultaneamente. 


\section{4) RAMOS TERMINAIS DOS NERVOS FRÊNICOS DIREITO E ESQUERDO, CONSIDERADOS EM CONJUNTO (Quadro 4)}

a) Em 5 peças (16,67\%), atinentes a 2 fêmeas e 3 machos (Obs. 3F, 5M, 6F, $25 \mathrm{M}$ e 29M), deparamos com os nervos frênicos direito e esquerdo fornecendo concomitantemente os ramos lombar, costal e esternal.

b) Em 5 oportunidades (16,67\%), sendo 3 de fêmeas e 2 de machos (Obs. 15F, $16 \mathrm{~F}, 21 \mathrm{~F}, 22 \mathrm{M}$ e $28 \mathrm{M}$ ) notamos o nervo frênico direito fornecendo o tronco lombocostal e ramo esternal e o nervo frênico esquerdo os ramos lombar, costal e esternal, simultaneamente.

c) Em 3 casos (10,00\%), pertencentes a exemplares machos (Obs. 10M, 11M e 26M), observamos o nervo frênico direito resolvendo-se em ramos lombar, costal e esternal e o nervo frênico esquerdo em ramo lombar e tronco costoesternal.

d) Em 3 diafragmas (10,00\%), relativos a 2 fêmeas e 1 macho (Obs. 14F, 19F e $27 \mathrm{M})$, verificamos os nervos frênicos direito e esquerdo emitindo o tronco lombocostal e o ramo esternal.

e) Em 3 dissecações (10,00\%), atinentes a machos (Obs. 13M,18M e 30M), notamos o nervo frênico direito dividindo-se em tronco lombocostal e ramo esternal, enquanto o nervo frênico esquerdo divide-se em ramo lombar e tronco costoesternal. 
f) Em 2 casos (6,67\%), pertinentes 1 fêmea e 1 macho (Obs. 4M e 17F), presenciamos os nervos frênicos direito e esquerdo emitindo o ramo lombar e o tronco costoesternal.

g) Em 2 diafragmas (6,67\%), sendo 1 de fêmea e 1 de macho (Obs. $7 \mathrm{~F}$ e 24M), notamos o nervo frênico direito fornecendo simultaneamente os ramos lombar, costal e esternal e, o nervo frênico esquerdo, o tronco lombocostal e o ramo esternal.

h) Em 2 peças (6,67\%), pertencentes a 2 machos (Obs. 9M e 12M), surpreendemos o nervo frênico direito dividindo-se em troncos lombocostal e costoesternal e o nervo frênico esquerdo em ramos lombar, costal (em número de dois) e esternal.

i) Em 1 oportunidade (3,33\%), relativa a 1 macho (Obs. $2 \mathrm{M})$, encontramos os nervos frênicos direito e esquerdo resolvendo-se simultaneamente nos troncos lombocostal e costoesternal.

j) Em 1 caso (3,33\%), atinente a 1 macho (Obs. $1 \mathrm{M})$, surpreendemos o nervo frênico direito emitindo o tronco lombocostal e os ramos costal e esternal e, o nervo frênico esquerdo, os ramos lombar, costal (em número de dois) e esternal.

k) Em 1 preparação (3,33\%), pertinente a 1 macho (Obs. 8M), evidenciamos que o nervo frênico direito emite os troncos lombocostal e costoesternal e, o nervo frênico esquerdo, os ramos lombar, costal e esternal. 
I) Em 1 diafragma (3,33\%), pertencente a 1 macho (Obs. 20M), encontramos o nervo frênico direito fornecendo os troncos lombocostal e costoesternal e, o nervo frênico esquerdo, o tronco lombocostal e o ramo esternal.

m) Em 1 preparação (3,33\%), de macho (Obs. 23M), observamos o nervo frênico direito fornecendo o tronco lombocostal e o ramo esternal e, o nervo frênico esquerdo, os ramos lombar, costal (em número de dois) e esternal concomitantemente.

5) DISTRIBUIÇÃO DO RAMO LOMBAR DO NERVO FRÊNICO DIREITO (Quadro 5)

a) Em 15 preparações (50,00\%), correspondentes a 6 fêmeas e 9 machos (Obs. 1M, 3F, 4M, 5M, 6F, 7F, 8M, 10M, 15F, 16F, 19F, 20M, 25M, 26M e 28M), identificamos o ramo lombar distribuindo-se no pilar direito do diafragma (pars lumbalis) e emitindo pequeno filete nervoso à veia cava caudal.

b) Em 14 dissecações (46,67\%), atinentes a 3 fêmeas e 11 machos (Obs. 9M, 11M, 12M, 13M, 14F, 17F, 18M, 21F, 22M, 23M, 24M, 27M, 29M e 30M), deparamos com o ramo lombar alcançado somente o pilar direito do diafragma (pars lumbalis).

c) Em 1 peça (3,33\%), pertencente a 1 macho (Obs.2M), presenciamos o ramo lombar emitindo ramos ao pilar direito do diafragma (pars lumbalis) e filete nervoso à veia cava caudal e ao folíolo dorsal direito do diafragma. 
6) DISTRIBUIÇÃO DO RAMO LOMBAR DO NERVO FRÊNICO ESQUERDO (Quadro 5)

a) Em 29 casos (96,67\%), atinentes a 9 fêmeas e 20 machos (Obs. 1M, 2M, 3F, 5M, 6F, 7F, 8M, 9M, 10M, 11M, 12M, 13M, 14F, 15F, 16F, 17F, 18M,19F, 20M, 21F, 22M, 23M, 24M, 25M, 26M, 27M, 28M, 29M e 30M), deparamos com o ramo lombar distribuindo-se apenas no pilar esquerdo do diafragma (pars lumbalis).

b) Em 1 peça (3,33\%), correspondente a 1 macho (Obs. 4M), observamos 0 ramo lombar atingindo o pilar esquerdo (pars lumbalis) e emitindo filete nervoso ao folíolo dorsal esquerdo do diafragma.

7) DISTRIBUIÇÃO DO RAMO COSTAL DO NERVO FRÊNICO DIREITO (Quadro 6)

a) Em 17 preparações (56,67\%), pertencentes a 5 fêmeas e 12 machos (Obs. $4 \mathrm{M}, 5 \mathrm{M}, 7 \mathrm{~F}, 10 \mathrm{M}, 11 \mathrm{M}, 13 \mathrm{M}, 16 \mathrm{~F}, 17 \mathrm{~F}, 18 \mathrm{M}, 19 \mathrm{~F}, 21 \mathrm{~F}, 23 \mathrm{M}, 24 \mathrm{M}, 25 \mathrm{M}, 26 \mathrm{M}, 27 \mathrm{M}$ e 28M), registramos o ramo costal alcançando as regiões dorsal e ventral da pars costalis do diafragma.

b) Em 6 diafragmas (20,00\%), 1 de fêmea e 5 de machos (Obs. 1M, 2M, 8M, $12 \mathrm{M}, 14 \mathrm{~F}$ e 20M), observamos dois ramos costais que se distribuem nas regiões dorsal e ventral da pars costalis do diafragma.

c) Em 5 oportunidades (16,67\%), correspondentes a 2 fêmeas e 3 machos (Obs. $3 F, 6 F, 22 M, 29 M$ e 30M), notamos o ramo costal distribuindo-se nas regiões 
dorsal e ventral da pars costalis do diafragma e emitindo também, filete nervoso ao folíolo ventral.

d) Em 1 caso (3,33\%), de macho (Obs. 9M), surpreendemos dois ramos costais que se distribuem nas regiões dorsal e ventral da pars costalis do diafragma, emitindo também, um deles, filete nervoso ao folíolo ventral.

e) Em 1 peça (3,33\%), pertencente a 1 fêmea (Obs. 15F), encontramos o ramo costal atingindo as regiões dorsal e ventral da pars costalis do diafragma e fornecendo também, dois filetes nervosos ao folíolo ventral.

\section{8) DISTRIBUIÇÃO DO RAMO COSTAL DO NERVO FRÊNICO ESQUERDO} (Quadro 6)

a) Em 21 diafragmas (70,00\%), relativos a 8 fêmeas e 13 machos (Obs. 3F, 5M, $6 \mathrm{~F}, 10 \mathrm{M}, 11 \mathrm{M}, 13 \mathrm{M}, 14 \mathrm{~F}, 15 \mathrm{~F}, 16 \mathrm{~F}, 17 \mathrm{~F}, 18 \mathrm{M}, 19 \mathrm{~F}, 20 \mathrm{M}, 21 \mathrm{~F}, 24 \mathrm{M}, 25 \mathrm{M}, 26 \mathrm{M}$, $27 \mathrm{M}, 28 \mathrm{M}, 29 \mathrm{M}$ e $30 \mathrm{M})$, observamos o ramo costal distribuindo-se nas regiões dorsal e ventral da pars costalis do diafragma.

b) Em 6 peças (20,00\%), atinentes a 6 machos (Obs. 1M, 2M, 8M, 9M, 12M e 23M), deparamos com 2 ramos costais distribuindo-se nas regiões dorsal e ventral da pars costalis do diafragma.

c) Em 3 oportunidades (10,00\%), correspondentes a 1 fêmea e 2 machos (Obs. $4 \mathrm{M}, 7 \mathrm{~F}$ e 22M), notamos o ramo costal destinando-se às regiões dorsal e ventral da pars costalis do diafragma, além de emitir filete nervoso para o folíolo ventral. 
9) DISTRIBUIÇÃO DO RAMO ESTERNAL DO NERVO FRÊNICO DIREITO (QUADRO 7)

a) Em todas as 30 preparações (100,00\%), sendo 9 de fêmeas e 21 de machos (Obs. 1M, 2M, 3F, 4M, 5M, 6F, 7F, 8M, 9M, 10M, 11M, 12M, 13M, 14F, 15F, 16F, 17F, 18M, 19F, 20M, 21F, 22M, 23M, 24M, 25M, 26M, 27M, 28M, 29M e 30M), verificamos o ramo esternal distribuindo-se na pars sternalis (antímero direito) e na região ventral da pars costalis do diafragma.

10) DISTRIBUIÇÃO DO RAMO ESTERNAL DO NERVO FRÊNICO ESQUERDO (Quadro 7)

a) Em 25 casos (83,33\%), pertencentes a 9 fêmeas e 16 machos ( Obs. 3F, 4M, 5M, 6F, 7F, 8M, 10M, 11M, 12M, 13M, 14F, 15F, 16F,17F, 18M, 19F, 20M, 21F, 22M, 24M, 25M, 26M, 28M, 29M e 30M), encontramos o ramo esternal destinando-se à pars sternalis (antímero esquerdo) e à região ventral da pars costalis do diafragma.

b) Em 2 diafragmas (6,67\%), correspondentes a 2 machos (Obs. 1M e 2M), notamos o ramo esternal distribuindo-se somente na pars sternalis do diafragma (antímero esquerdo).

c) Em 2 casos (6,67\%), pertinentes a 2 machos (Obs. $9 \mathrm{M}$ e 23M), observamos 0 ramo esternal alcançando a pars sternalis (antímero esquerdo) e a região ventral da pars costalis do diafragma, emitindo também, filete nervoso ao folíolo ventral. 
d) Em 1 oportunidade (3,33\%), atinente a 1 macho (Obs. 27M), surpreendemos o ramo esternal distribuindo-se na pars sternalis (antímero esquerdo), e na região ventral da pars costalis do diafragma e destinando, ainda, filete nervoso para uma pequena área circular muscular localizada no folíolo ventral.

Em nenhuma das 30 preparações dissecadas correspondentes a 9 fêmeas e 21 machos (Obs. 1M, 2M, 3F, 4M, 5M, 6F, 7F, 8M, 9M, 10M, 11M, 12M, 13M, 14F, $15 \mathrm{~F}, 16 \mathrm{~F}, 17 \mathrm{~F}, 18 \mathrm{M}, 19 \mathrm{~F}, 20 \mathrm{M}, 21 \mathrm{~F}, 22 \mathrm{M}, 23 \mathrm{M}, 24 \mathrm{M}, 25 \mathrm{M}, 26 \mathrm{M}, 27 \mathrm{M}, 28 \mathrm{M}, 29 \mathrm{M}$ e 30M), foram observadas conexões ("anastomoses") homo e/ou heterolaterais entre os ramos terminais dos nervos frênicos direito e esquerdo de ovinos da raça Santa Inês.

A divisão terminal dos nervos frênicos apresenta disposição simétrica somente em 11 casos (36,67\%), pertencentes a 5 fêmeas e 6 machos (Obs. 2M, 3F, 4M, 5M, 6F, 14F, 17F, 19F, 25M, 27M e 29M) que exibem os seguintes arranjos em ambos os antímeros: ramos lombar, costal e esternal (Obs. 3F, 5M, 6F, 25M e 29M); tronco lombocostal e ramo esternal (Obs. 14F, 19F e 27M); ramo lombar e tronco costoesternal (Obs. 4M e 17F) e troncos lombocostal e costoesternal (Obs. 2M).

Pela aplicação do teste de associação, verificou-se que não há influência da variável sexo sobre a distribuição dos nervos frênicos, tudo ocorrendo pelo acaso, como se pode ver pela apreciação dos valores de $X^{2}$ no Quadro 8. 
11) PARTICIPAÇÃO DE OUTROS NERVOS NA INERVAÇÃO DO DIAFRAGMA

a) NERVOS INTERCOSTAIS

Em 19 oportunidades (63,33\%), sendo 6 de fêmeas e de 13 de machos (Obs. 9M, 10M, 11M, 13M, 14F, 15F, 16F, 17F, 18M, 19F, 20M, 21F, 23M, 24M, 25M, 27M, 28M, 29M e 30M), observamos a contribuição de nervos intercostais ( do VIII ao XII pares) na inervação do diafragma em ambos os antímeros (Fig. 21).

Porém, em 1 dissecação (3,33\%), atinente a 1 macho (Obs. 26M), notamos que o XII nervo intercostal não participa da inervação do diafragma no antímero esquerdo (Fig. 22).

Em 1 caso (3,33\%), pertencente a 1 macho (Obs. 22M), verificamos a contribuição dos nervos intercostais (do VIII ao XIII pares) na inervação do diafragma em ambos os antímeros (Fig. 23).

Em 8 peças (26,68\%), correspondentes a 3 fêmeas e 5 machos (Obs. 1M, 2M, $3 \mathrm{~F}, 4 \mathrm{M}, 5 \mathrm{M}, 6 \mathrm{~F}, 7 \mathrm{~F}$ e 12M), notamos a contribuição dos nervos intercostais ( do IX ao XII pares) na inervação do diafragma em ambos os antímeros (Fig. 24).

Por sua vez, em 1 exemplar (3,33\%), correspondente a 1 macho (Obs. 8M), constatamos a ausência do IX nervo intercostal na inervação do diafragma no antímero direito.

Em todas as peças dissecadas (100,00\%) observamos que estes nervos intercostais destinam-se à porção mais lateral da pars costalis e distribuem-se ime- 
diatamente, em correspondência à linha de inserção costal do diafragma, em curtos ramos que mergulham na porção periférica da parte carnosa.

Não há diferença estatisticamente significante no relativo à participação de nervos intercostais direito e esquerdo no diafragma dos animais estudados, quando comparados machos e fêmeas, como pode ser verificado pelos valores do $X^{2}$ (à direita $X^{2}$ é igual a 1,07 e à esquerda $X^{2}$ é igual a 0,927).

b) NERVOS LOMBARES

Não verificamos contribuição de nervos lombares na inervação dos 30 diafragmas dissecados neste trabalho. 
QUADRO 1 - ORIGEM DAS RAÍZES FORMADORAS DOS NERVOS FRÊNICOS DE OVINOS DA RAÇA SANTA INÊS

\begin{tabular}{|c|c|c|c|c|c|}
\hline \multirow[t]{2}{*}{ TIPOS } & \multirow[t]{2}{*}{$\begin{array}{l}\text { RAÍZES FORMADORAS } \\
\text { DOS NERVOS FRÊNICOS }\end{array}$} & \multicolumn{2}{|c|}{$\begin{array}{c}\text { NERVO FRÊNICO } \\
\text { DIREITO }\end{array}$} & \multicolumn{2}{|c|}{$\begin{array}{c}\text { NERVO FRÊNICO } \\
\text { ESQUERDO }\end{array}$} \\
\hline & & $\mathbf{N}$ & $\%$ & $\mathbf{N}$ & $\%$ \\
\hline 1 & C6 & - & - & 2 & 6,67 \\
\hline \multirow{4}{*}{ II } & C5, C6 & 11 & 36,67 & 10 & 33,34 \\
\hline & $\mathrm{C} 6, \mathrm{C} 7$ & 6 & 20,00 & 4 & 13,33 \\
\hline & C5,C6(2 filetes) & 4 & 13,33 & 3 & 9,99 \\
\hline & C6 (2 filetes), C7 & 1 & 3,33 & 1 & 3,33 \\
\hline \multirow[t]{2}{*}{ III } & $\mathrm{C} 5, \mathrm{C} 6, \mathrm{C} 7$ & 6 & 20,00 & 10 & 33,34 \\
\hline & C5, C6 (2 filetes), C7 & 2 & 6,67 & - & - \\
\hline & TOTAL & 30 & 100,00 & 30 & 100,00 \\
\hline
\end{tabular}

FONTE: Pesquisa de campo elaborada pela doutoranda Ana Elisa Almeida. Fevereiro 2002. 
QUADRO 2 - NÍVEIS DE UNIÃO DAS RAÍZES FORMADORAS DO NERVO FRÊNICO DIREITO DE OVINOS DA RAÇA SANTA INÊS

\begin{tabular}{|c|c|c|c|c|c|c|c|c|}
\hline \multirow{3}{*}{$\begin{array}{c}\text { RAÍZES } \\
\text { FROMADORAS }\end{array}$} & \multicolumn{6}{|c|}{ NÍVEIS DE UNIÃO } & \multirow{2}{*}{\multicolumn{2}{|c|}{$\begin{array}{l}N^{\circ} \text { DE CASOS } \\
\text { OBSERVADOS }\end{array}$}} \\
\hline & \multicolumn{2}{|c|}{$1^{a}$ COSTELA } & \multicolumn{2}{|c|}{$\mathrm{C} 7$} & \multicolumn{2}{|c|}{ C6 } & & \\
\hline & & $\%$ & $\mathrm{~N}$ & $\%$ & $\mathrm{~N}$ & $\%$ & $\mathrm{~N}^{\circ}$ & $\%$ \\
\hline $\begin{array}{l}\mathrm{C} 5 \text { e } \mathrm{C} 6 \\
\mathrm{C} 6 \text { e } \mathrm{C} 7\end{array}$ & 12 & 40,00 & 2 & 6,67 & 2 & 6,67 & 16 & 53,34 \\
\hline C5 e C6 (2 filetes) & & & & & & & 4 & 13,33 \\
\hline $\begin{array}{l}\text { União dos filetes } \\
\text { de C6 }\end{array}$ & - & - & 4 & 13,33 & - & - & & \\
\hline $\begin{array}{l}\text { União do tronco } \\
\text { com filete de C5 }\end{array}$ & 4 & 13,33 & - & - & - & - & & \\
\hline C6 (2 filetes) e C7 & & & & & & & 1 & 3,33 \\
\hline $\begin{array}{l}\text { União do curto } \\
\text { Filete de C6 com } \\
\text { o filete de C7 }\end{array}$ & - & - & 1 & 3,33 & - & - & & \\
\hline $\begin{array}{l}\text { União do tronco } \\
\text { com filete maior } \\
\text { de C6 }\end{array}$ & 1 & 3,33 & - & - & - & - & & \\
\hline $\mathrm{C} 5, \mathrm{C} 6$ e $\mathrm{C} 7$ & & & & & & & 7 & 23,33 \\
\hline $\begin{array}{l}\text { União do filete de } \\
\text { C6 com o filete de } \\
\text { C7 }\end{array}$ & - & - & 7 & 23,33 & - & - & & \\
\hline $\begin{array}{l}\text { União do tronco } \\
\text { com filete de C5 }\end{array}$ & 7 & 23,33 & - & - & - & - & & \\
\hline $\begin{array}{c}\text { C5, C6 (2 filetes) } \\
\text { e C7 }\end{array}$ & & & & & & & 2 & 6,67 \\
\hline $\begin{array}{l}\text { União do curto } \\
\text { filete de } \mathrm{C} 6 \mathrm{com} \text { o } \\
\text { filete de } \mathrm{C} 7\end{array}$ & - & - & 2 & 6,67 & - & - & & \\
\hline $\begin{array}{l}\text { União do tronco } \\
\text { com filete maior } \\
\text { de C6 }\end{array}$ & - & - & 2 & 6,67 & - & - & & \\
\hline $\begin{array}{l}\text { União do tronco } \\
\text { com o filete de C5 }\end{array}$ & 2 & 6,67 & - & - & - & - & & \\
\hline & & $\mathrm{TO}$ & TA L & & & & 30 & 100,00 \\
\hline
\end{tabular}

FONTE: Pesquisa de campo elaborada pela doutoranda Ana Elisa Almeida.

Fevereiro, 2002. 
QUADRO 3 - NÍVEIS DE UNIÃO DAS RAÍZES FORMADORAS DO NERVO FRÊNICO ESQUERDO DE OVINOS DA RAÇA SANTA INÊS

\begin{tabular}{|c|c|c|c|c|c|c|c|c|}
\hline \multirow{3}{*}{$\begin{array}{c}\text { RAÍZES } \\
\text { FROMADORAS }\end{array}$} & \multicolumn{6}{|c|}{ NÍVEIS DE UNIÃO } & \multirow{2}{*}{\multicolumn{2}{|c|}{$\begin{array}{l}N^{\circ} \text { DE CASOS } \\
\text { OBSERVADOS }\end{array}$}} \\
\hline & \multirow{2}{*}{\multicolumn{2}{|c|}{$1^{\text {a }}$ COSTELA }} & \multicolumn{2}{|c|}{$\mathrm{C} 7$} & \multicolumn{2}{|c|}{ C6 } & & \\
\hline & & $\%$ & $\mathrm{~N}^{\circ}$ & $\%$ & $\mathrm{~N}^{\circ}$ & $\%$ & $\mathrm{~N}^{\circ}$ & $\%$ \\
\hline $\begin{array}{l}\mathrm{C} 5 \text { e } \mathrm{C} 6 \\
\mathrm{C} 6 \text { e } \mathrm{C} 7\end{array}$ & 10 & 35,71 & 1 & 3,57 & 3 & 10,71 & 14 & 49,99 \\
\hline C5 e C6 (2 filetes) & & & & & & & 3 & 10,71 \\
\hline $\begin{array}{l}\text { União dos filetes } \\
\text { de C6 }\end{array}$ & - & - & 2 & 7,14 & - & - & & \\
\hline $\begin{array}{l}\text { União do tronco } \\
\text { com filete de C5 }\end{array}$ & 2 & 7,14 & - & - & - & - & 2 & 7,14 \\
\hline $\begin{array}{l}\text { União do filete de } \\
\text { C6 com o filete de } \\
\text { C5 }\end{array}$ & - & - & - & - & 1 & 3,57 & 1 & 3,57 \\
\hline $\begin{array}{l}\text { União do tronco } \\
\text { com o outro filete } \\
\text { de C6 }\end{array}$ & 1 & 3,57 & - & - & - & - & & \\
\hline C6 (2 filetes) e C7 & & & & & & & 1 & 3,33 \\
\hline $\begin{array}{l}\text { União do curto } \\
\text { filete de C6 com o } \\
\text { filete de C7 }\end{array}$ & - & - & 1 & 3,57 & - & - & & \\
\hline $\begin{array}{l}\text { União do tronco } \\
\text { com filete maior } \\
\text { de C6 }\end{array}$ & 1 & 3,57 & - & - & - & - & & \\
\hline C5, C6 e C7 & & & & & & & 10 & 35,73 \\
\hline $\begin{array}{l}\text { União do filete de } \\
\text { C6 com o filete de } \\
\text { C7 }\end{array}$ & - & - & 9 & 32,16 & - & - & 9 & 32,16 \\
\hline $\begin{array}{l}\text { União do tronco } \\
\text { com filete de C5 }\end{array}$ & 9 & 32,16 & - & - & - & - & & \\
\hline $\begin{array}{c}\text { União do filete de } \\
\text { C5 com o filete de } \\
\text { C7 }\end{array}$ & - & - & - & - & 1 & 3,57 & 1 & 3,57 \\
\hline $\begin{array}{l}\text { União do tronco } \\
\text { com o filete de C6 }\end{array}$ & 1 & 3,57 & - & - & - & - & & \\
\hline & & TO & $A L$ & & & & 28 & 100,00 \\
\hline
\end{tabular}

FONTE: Pesquisa de campo elaborada pela doutoranda Ana Elisa Almeida. Fevereiro, 2002. 
QUADRO 4 - RAMOS TERMINAIS DOS NERVOS FRÊNICOS DIREITO E ESQUERDO, DE OVINOS DA RAÇA SANTA INÊS CONSIDERADOS EM CONJUNTO

\begin{tabular}{|c|c|c|c|}
\hline $\begin{array}{c}\text { NERVO FRÊNICO } \\
\text { DIREITO }\end{array}$ & \multirow[t]{2}{*}{$\begin{array}{c}\text { NERVO FRÊNICO } \\
\text { ESQUERDO }\end{array}$} & \multicolumn{2}{|c|}{$\begin{array}{l}\text { NÚMERO DE CASOS } \\
\text { OBSERVADOS }\end{array}$} \\
\hline & & $\mathrm{N}$ & $\%$ \\
\hline \multicolumn{4}{|c|}{ RAMOS TERMINAIS } \\
\hline $\begin{array}{c}\text { RAMOS LOMBAR, COSTAL E } \\
\text { ESTERNAL }\end{array}$ & $\begin{array}{c}\text { RAMOS LOMBAR, COSTAL E } \\
\text { ESTERNAL }\end{array}$ & 5 & 16,67 \\
\hline $\begin{array}{l}\text { TRONCO LOMBOCOSTAL E } \\
\text { RAMO ESTERNAL }\end{array}$ & $\begin{array}{c}\text { RAMOS LOMBAR, COSTAL E } \\
\text { ESTERNAL }\end{array}$ & 5 & 16,67 \\
\hline $\begin{array}{l}\text { RAMOS LOMBAR, COSTAL E } \\
\text { ESTERNAL }\end{array}$ & $\begin{array}{c}\text { RAMO LOMBAR E TRONCO } \\
\text { COSTOESTERNAL }\end{array}$ & 3 & 10,00 \\
\hline $\begin{array}{c}\text { TRONCO LOMBOCOSTAL E } \\
\text { RAMO ESTERNAL }\end{array}$ & $\begin{array}{c}\text { TRONCO LOMBOCOSTAL E } \\
\text { RAMO ESTERNAL }\end{array}$ & 3 & 10,00 \\
\hline $\begin{array}{c}\text { TRONCO LOMBOCOSTAL E } \\
\text { RAMO ESTERNAL }\end{array}$ & $\begin{array}{l}\text { RAMO LOMBAR E TRONCO } \\
\text { COSTOESTERNAL }\end{array}$ & 3 & 10,00 \\
\hline $\begin{array}{c}\text { RAMO LOMBAR E TRONCO } \\
\text { COSTOESTERNAL }\end{array}$ & $\begin{array}{c}\text { RAMO LOMBAR E TRONCO } \\
\text { COSTOESTERNAL }\end{array}$ & 2 & 6,67 \\
\hline $\begin{array}{c}\text { RAMOS LOMBAR, COSTAL E } \\
\text { ESTERNAL }\end{array}$ & $\begin{array}{l}\text { TRONCO LOMBOCOSTAL E } \\
\text { RAMO ESTERNAL }\end{array}$ & 2 & 6,67 \\
\hline $\begin{array}{l}\text { TRONCOS LOMBOCOSTAL E } \\
\text { COSTOESTERNAL }\end{array}$ & $\begin{array}{l}\text { RAMOS LOMBAR, COSTAL } \\
\text { (2) E ESTERNAL }\end{array}$ & 2 & 6,67 \\
\hline $\begin{array}{c}\text { TRONCOS LOMBOCOSTAL E } \\
\text { COSTOESTERNAL }\end{array}$ & $\begin{array}{c}\text { TRONCOS LOMBOCOSTAL } \\
\text { E COSTOESTERNAL }\end{array}$ & 1 & 3,33 \\
\hline $\begin{array}{c}\text { TRONCO LOMBOCOSTAL E } \\
\text { RAMOS COSTAL E } \\
\text { ESTERNAL }\end{array}$ & $\begin{array}{l}\text { RAMOS LOMBAR, COSTAL } \\
\text { (2) E ESTERNAL }\end{array}$ & 1 & 3,33 \\
\hline $\begin{array}{l}\text { TRONCOS LOMBOCOSTAL E } \\
\text { COSTOESTERNAL }\end{array}$ & $\begin{array}{c}\text { RAMOS LOMBAR, COSTAL E } \\
\text { ESTERNAL }\end{array}$ & 1 & 3,33 \\
\hline $\begin{array}{l}\text { TRONCOS LOMBOCOSTAL E } \\
\text { COSTOESTERNAL }\end{array}$ & $\begin{array}{l}\text { TRONCO LOMBOCOSTAL E } \\
\text { RAMO ESTERNAL }\end{array}$ & 1 & 3,33 \\
\hline $\begin{array}{c}\text { TRONCO LOMBOCOSTAL E } \\
\text { RAMO ESTERNAL }\end{array}$ & $\begin{array}{l}\text { RAMOS LOMBAR, COSTAL } \\
\text { (2) E ESTERNAL }\end{array}$ & 1 & 3,33 \\
\hline TO & TA L & 30 & 100,00 \\
\hline
\end{tabular}

FONTE: Pesquisa de campo elaborada pela doutoranda Ana Elisa Almeida. Fevereiro, 2002. 
QUADRO 5 - DISTRIBUIÇÃO DOS RAMOS LOMBARES DOS NERVOS FRÊNICOS DIREITO E ESQUERDO DE OVINOS DA RAÇA SANTA INÊS

\begin{tabular}{|c|c|c|c|c|}
\hline \multirow[t]{2}{*}{ ESTRUTURAS INERVADAS } & \multicolumn{2}{|c|}{$\begin{array}{c}\text { NERVO FRÊNICO } \\
\text { DIREITO }\end{array}$} & \multicolumn{2}{|c|}{$\begin{array}{l}\text { NERVO FRÊNICO } \\
\text { ESQUERDO }\end{array}$} \\
\hline & & $\begin{array}{r}\text { BBAR } \\
\% \\
\end{array}$ & & $\begin{array}{r}\text { BBAR } \\
\% \\
\end{array}$ \\
\hline $\begin{array}{l}\text { PILAR HOMOLATERAL VEIA CAVA } \\
\text { CAUDAL }\end{array}$ & 15 & 50,00 & - & - \\
\hline PILAR HOMOLATERAL & 14 & 46,66 & 29 & 96,67 \\
\hline $\begin{array}{l}\text { PILAR HOMOLATERAL } \\
\text { VEIA CAVA CAUDAL E FOLIIOLO } \\
\text { DORSAL DIREITO }\end{array}$ & 1 & 3,33 & - & - \\
\hline $\begin{array}{l}\text { PILAR HOMOLATERAL E FOLÍOLO } \\
\text { DORSAL ESQUERDO }\end{array}$ & - & - & 1 & 3,33 \\
\hline TOTAL & 30 & 100,00 & 30 & 100,00 \\
\hline
\end{tabular}

FONTE: Pesquisa de campo elaborada pela doutoranda Ana Elisa Almeida.

Fevereiro, 2002. 
QUADRO 6 - DISTRIBUIÇÃO DOS RAMOS COSTAIS DOS NERVOS FREANICOS DIREITO E ESQUERDO DE OVINOS DA RAÇA SANTA INÊS

\begin{tabular}{|c|cc|cc|}
\hline \multirow{2}{*}{ ESTRUTURAS INERVADAS } & \multicolumn{2}{|c|}{$\begin{array}{c}\text { NERVO FRÊNICO } \\
\text { DIREITO }\end{array}$} & \multicolumn{2}{|c|}{$\begin{array}{c}\text { NERVO FRÊNICO } \\
\text { ESQUERDO }\end{array}$} \\
\cline { 2 - 5 } & \multicolumn{2}{|c|}{$\begin{array}{c}\text { RAMO COSTAL } \\
\text { NAMO }\end{array}$} & \multicolumn{2}{|c|}{$\begin{array}{c}\text { RAMO COSTAL } \\
\%\end{array}$} \\
\hline $\begin{array}{c}\text { REGIÕES DORSAL E VENTRAL DA } \\
\text { PARS COSTALIS HOMOLATERAL }\end{array}$ & 23 & 76,67 & 27 & 90,00 \\
$\begin{array}{c}\text { REGIÕES DORSAL E VENTRAL DA } \\
\text { PARS COSTALIS HOMOLATERAL } \\
\text { E FOLIOLO VENTRAL }\end{array}$ & 7 & 23,33 & 3 & 10,00 \\
\hline TOTAL & 30 & 100,00 & 30 & 100,00 \\
\hline
\end{tabular}

FONTE: Pesquisa de campo elaborada pela doutoranda Ana Elisa Almeida.

Fevereiro, 2002. 
QUADRO 7 - DISTRIBUIÇÃO DOS RAMOS ESTERNAIS DOS NERVOS FRÊNICOS DIREITO E ESQUERDO DE OVINOS DA RAÇA SANTA INÊS

\begin{tabular}{|c|c|c|c|c|}
\hline \multirow[t]{2}{*}{ ESTRUTURAS INERVADAS } & \multicolumn{2}{|c|}{$\begin{array}{c}\text { NERVO FRÊNICO } \\
\text { DIREITO }\end{array}$} & \multicolumn{2}{|c|}{$\begin{array}{c}\text { NERVO FRÊNICO } \\
\text { ESQUERDO }\end{array}$} \\
\hline & & $\begin{array}{r}\text { ERNAL } \\
\%\end{array}$ & $\begin{array}{l}\text { RA } \\
\mathrm{N}\end{array}$ & $\begin{array}{c}\text { ERNAL } \\
\%\end{array}$ \\
\hline $\begin{array}{l}\text { PARS STERNALIS E REGIÃO VENTRAL } \\
\text { DA PARS COSTALIS HOMOLATERAL }\end{array}$ & 30 & 100,00 & 25 & 83,33 \\
\hline PARS STERNALIS HOMOLATERAL & - & - & 2 & 6,67 \\
\hline $\begin{array}{l}\text { PARS STERNALIS, REGIÃO VENTRAL } \\
\text { DA PARS COSTALIS HOMOLATERAL E } \\
\text { FOLIOLOO VENTRAL }\end{array}$ & - & - & 1 & 3,33 \\
\hline $\begin{array}{l}\text { PARS STERNALIS, REGIÃO VENTRAL } \\
\text { DA PARS COSTALIS HOMOLATERAL E } \\
\text { AREA CIICULAR MUSCULAR NO } \\
\text { FOLIOLOO VENTRAL }\end{array}$ & - & - & 1 & 3,33 \\
\hline TOTAL & 30 & 100,00 & 30 & 100,00 \\
\hline
\end{tabular}

FONTE: Pesquisa de campo elaborada pela doutoranda Ana Elisa Almeida.

Fevereiro, 2002. 


\section{QUADRO 8 - TESTE DE ASSOCIAÇÃO ENTRE SEXO E DIFERENTES DISPOSIÇÕES DOS NERVOS FRÊNICOS DIREITO E ESQUERDO DE OVINOS DA RAÇA SANTA INÊS}

\begin{tabular}{|c|c|c|}
\hline $\begin{array}{c}\text { DISPOSIÇÕES DOS } \\
\text { NERVOS FRÊNICOS }\end{array}$ & $\begin{array}{c}\text { VALOR ENCONTRADO } \\
\text { DE X }\end{array}$ & $\begin{array}{c}\text { SIGNIFICÂNCIA } \\
\text { P< } 0,05\end{array}$ \\
\hline RTNFD $^{(1)}$ & 4,24 & $\mathrm{NS}^{(8)}$ \\
RTNFE $^{(2)}$ & 6,87 & $\mathrm{NS}^{(8)}$ \\
DRLNFD $^{(3)}$ & 2,44 & $\mathrm{NS}^{(8)}$ \\
DRLNFE $^{(4)}$ & 0,44 & $\mathrm{NS}^{(8)}$ \\
DRCNFD $^{(5)}$ & 0,72 & $\mathrm{NS}^{(8)}$ \\
DRCNFE $^{(6)}$ & 0,18 & $\mathrm{NS}^{(8)}$ \\
DRENFEE $^{(7)}$ & 2,57 & $\mathrm{NS}^{(8)}$ \\
\hline
\end{tabular}

Fonte: Pesquisa de campo elabora pela doutoranda Ana Elisa Almeida Fevereiro de 2002.

(1) Ramos terminais do nervo frênico direito.

(2) Ramos terminais do nervo frênico esquerdo.

(3) Distribuição do ramo lombar do nervo frênico direito.

(4) Distribuição do ramo lombar do nervo frênico esquerdo.

(5) Distribuição do ramo costal do nervo frênico direito.

(6) Distribuição do ramo costal do nervo frênico esquerdo.

(7) Distribuição do ramo esternal do nervo frênico esquerdo.

(8) Não significante. 
Discussão 
Os resultados que obtivemos e a análise da literatura consultada permitem-nos tecer alguns comentários sobre o assunto. Ressaltamos que obedeceremos a mesma seqüência do capítulo anterior.

Assim, evidenciamos que a disposição geral das raízes formadoras dos nervos frênicos direito e esquerdo obedece ao padrão que, de modo geral, é descrito por diferentes autores relativamente às várias espécies animais estudadas.

Os resultados ora alcançados, mediante a dissecação e observação dos aludidos nervos, em 30 peças de ovinos da raça Santa Inês, fixados em solução aquosa de formol a 10,00\%, mostram que nesses animais, os nervos frênicos direito e esquerdo tomam origem a partir da união dos ramos ventrais do $5^{\circ}(\mathrm{C} 5)$ e $6^{\circ}$ (C6) nervos espinhais cervicais, mais freqüentemente, tanto à direita $(50,00 \%)$ como à esquerda (43,33\%). Esta mesma disposição foi encontrada em gatos por REIGHARD e JENNINGS (1957) apudSANT'AMBROGIO (1963), em cães sem raça definida por DIAS et al. (1974) e em gatos sem raça definida por TAMEGA et al. (1975). Acreditamos que esses achados estejam coerentes com a alusão de GHOSHAL (1975) de que para ovinos e caprinos, a contribuição do $7^{\circ}(\mathrm{C} 7)$ nervo espinhal cervical ou é pequena ou está ausente.

Ainda quanto à origem dos nervos frênicos, nos ovinos da raça Santa Inês, pudemos verificar que essas estruturas podem também tomar origem a partir dos ramos ventrais do $5^{\circ}(\mathrm{C} 5), 6^{\circ}(\mathrm{C} 6)$ e $7^{\circ}(\mathrm{C} 7)$ nervos espinhais cervicais, com uma menor freqüência, ou seja, 26,67\% à direita e 33,34\% à esquerda.

Essa descrição é concordante com o referido pela maioria dos autores consultados, seja os de Compêndios de Anatomia Veterinária, seja os de trabalhos especializados. Entre os primeiros, destacamos CHAUVEAU, et al. (1905b); 
LESBRE (1923); ZIMMERL (1905, 1930); ELLENBERGER e BAUM (1932); DOBBERSTEIN e HOFFMAN (1964); SCHWARZE e SCHRÖDER (1972); NICKEL et al. (1977); GHOSHAL (1975); BARONE (1989); DYCE et al. (1990) e EVANS (1993) que consideram simplesmente que os nervos frênicos direito e esquerdo emergem dos ramos ventrais do $5^{\circ}(\mathrm{C} 5), 6^{\circ}(\mathrm{C} 6)$ e $7^{\circ}(\mathrm{C} 7)$ nervos espinhais cervicais. Entre os trabalhos especializados, encontramos o de LOCCHI (1931) em Bradypus tridactylus, o de LUTNICKI (1950) em carneiros, inclusive fetos, o de GIROLLA (1955) em bovinos, entre adultos, novilhas e fetos, o de BAMEL et al. (1970) em búfalos jovens, o de DIAS et al. (1974) em cães sem raça definida, o de SOUZA et al. (1985) em fetos de bovinos azebuados e o de DALECK (1991) em cães sem raça definida. Esses autores apresentam relatos semelhantes quanto à origem dos nervos frênicos nas diferentes espécies estudadas, isto é, a partir dos ramos ventrais do $5^{\circ}(\mathrm{C} 5), 6^{\circ}(\mathrm{C} 6)$ e $7^{\circ}(\mathrm{C} 7)$ nervos espinhais cervicais.

Também não constitui uma ocorrência rara, nos ovinos da raça Santa Inês, a origem dos nervos frênicos a partir dos ramos ventrais do $6^{\circ}(\mathrm{C} 6)$ e $7^{\circ}(\mathrm{C} 7)$ nervos espinhais cervicais, ocorrência que aparece em $23,33 \%$ dos casos à direita e em 16,66\% das oportunidades à esquerda. Achado semelhante foi também observado por SOUZA et al. (1985) em fetos de bovinos azebuados mas não por BAMEL et al. (1970), em búfalos.

Do mesmo modo que o relatado por GONZÁLEZ Y GARCIA e GONZÁLEZ ALVAREZ (1929) e por SCHWARZE e SCHRÖDER (1972) para ovinos, deparamos em duas oportunidades com o nervo frênico esquerdo procedente apenas de uma raiz, ou seja, do ramo ventral do $6^{\circ}(\mathrm{C} 6)$ nervo espinhal cervical. 
Relativamente à eventual participação de filetes nervosos oriundos de outros nervos espinhais cervicais na formação dos nervos frênicos que não $05^{\circ}$ (C5), $6^{\circ}$ (C6) e $7^{\circ}(\mathrm{C} 7)$ nervos espinhais cervicais, não houve registro dessa ocorrência em ovinos da raça Santa Inês. Entretanto, LOCCHI (1931) descreve, para o Bradypus tridactylus, na constituição do nervo frênico, a contribuição do $4^{\circ}$ (C4) nervo espinhal cervical e, em outros casos, também a participação do $8^{\circ}(\mathrm{C} 8)$ nervo espinhal cervical. GIROLLA (1955), da mesma forma descreve, para bovinos, que em $98,00 \%$ das oportunidades, no antímero direito, ocorre a participação do ramo ventral do $4^{\circ}(\mathrm{C} 4)$ nervo espinhal cervical na formação do nervo frênico. A presença deste ramo é igualmente relatada por DIAS et al. (1974) para cães, por TAMEGA et al. (1975) para gatos, por DAYOUB et al. (1981) para cobaias e por EVANS (1993), também para cães.

Nessa questão da contribuição de vários filetes nervosos na formação do nervo frênico, vale ressaltar a descrição feita por URBANOWICZ et al. (1966) segundo a qual, no homem, os nervos frênicos podem consistir de filetes nervosos provenientes do $2^{\circ}(\mathrm{C} 2)$ ao $5^{\circ}(\mathrm{C} 5)$ nervos espinhais cervicais, enquanto no Macacus rhesus e no Macacus cynomolgus, os nervos frênicos surgem de filetes nervosos oriundos do $4^{\circ}(\mathrm{C} 4), 5^{\circ}(\mathrm{C} 5)$ e $6^{\circ}(\mathrm{C} 6)$ nervos espinhais cervicais. Estes autores comentam também que nos "macacos mais evoluídos" a ausência ocasional de filete de C6 com a ocorrência de filete de C3 é observada. Do mesmo modo, a continuada "ascensão" da origem do nervo frênico no homem é evidenciada. Isto significa uma redução do filete de C5 e a ocorrência de filetes de C3 e C2. Desta forma, o nervo frênico no homem surge apenas do plexo cervical. Segundo ainda estes autores, os resultados obtidos nesse estudo sugerem que a participação de filetes nervosos de C6 e C7 na formação dos nervos frênicos pode ser considerada como um aspecto primitivo, enquanto a ausência desses filetes 
e uma certa redução do filete de $\mathrm{C} 5$, bem como a ocorrência de filetes provenientes de C2 e C3, são considerados como característica evolutiva.

Assim sendo, os nossos achados em ovinos da raça Santa Inês, quanto à origem dos nervos frênicos a partir da união de filetes nervosos procedentes dos ramos ventrais do $5^{\circ}(\mathrm{C} 5)$ ao $7^{\circ}(\mathrm{C} 7)$ nervos espinhais cervicais em diversos arranjos são sugestivos que, nesses espécimes, o padrão de composição dos nervos frênicos é do tipo primitivo. Pesquisas correlatas de caráter comparativo poderão, no futuro próximo, esclarecer tal suposição.

Reforçando esta "hipótese de evolução" relativamente à participação de várias raízes na inervação das diferentes partes do diafragma, é interessante lembrar o relatado por LOCCHI (1932b), de que, no macaco, C5 inerva a região ventral do diafragma enquanto que, no homem, essa raiz não inerva essa região mas, sim, sua região dorsal. Nos cães, conforme descrição de DALECK (1991), C5 inerva a pars sternalis, C6 a pars costalis e C7 quando presente, a pars lumbalis (inervada por C6 na ausência de C7). Nos gatos, segundo relato de SANT'AMBROGIO et al. (1963), a região costal é inervada parcialmente por C4 e principalmente por C5, enquanto a região vertebral é inervada parcialmente por C5 e principalmente por C6. Essas observações são extremamente interessantes pois sugerem que na evolução filogênica (e talvez no desenvolvimento ontogenético), estaria existindo uma migração ventro-dorsal (esterno-costo-lombar) na relação neurótomo-miótomo. Em outras palavras, estão surgindo evidências de que na evolução filogenética, raízes medulares cada vez mais craniais estão sendo implicadas na inervação do diafragma, sendo C6 a raiz principal no cão, C5 no gato, no macaco e no coelho e C4 no homem. Paralelamente ao deslocamento cranial da inserção das raízes do nervo frênico no grupo primata, também tem-se observado a ocorrência do mesmo fato, em relação ao plexo 
braquial, resultando o que os autores, a exemplo de WARWICK et al (1995), chamam de plexo "pré-fixado", em oposição ao tipo "pós-fixado", característico da maior parte dos animais quadrúpedes. Discute-se, ainda sem conclusões definitivas, a participação do fenômeno da bipedia como causa dessa ocorrência.

Relacionado a esse assunto está o aspecto abordado por LOCCHI (1932a), no que diz respeito aos nervos parafrênicos ou acessórios. Para esse autor, "naturalmente, é o volume de cada um dos feixes nervosos desse sistema frênicoparafrênico, que indicará qual deve ser considerado como principal; e na eventualidade, aliás rara, de dois feixes com a mesma origem e com mais ou menos o mesmo volume, poder-se-á designar como nervo frênico principal ou propriamente dito, o que seguir o trajeto aceito como típico do nervo frênico comum, habitual ou mais freqüente, especialmente em relação ao músculo escaleno". Assim, em ovinos da raça Santa Inês, segundo nossas observações, não identificamos a raiz principal pelo seu calibre, uma vez que as três raízes $\mathrm{C} 5$, C6 e C7 apresentaram-se com aproximadamente o mesmo volume em todas as oportunidades. Entretanto, caracterizamos a raiz $\mathrm{C} 5$ como a mais longa e a $\mathrm{C} 7$ como a mais curta. Esse achado coincide em parte com aquele apresentado por BAMEL et al. (1971) para búfalos, pois conforme esses autores, a raiz procedente do $5^{\circ}$ (C5) nervo espinhal cervical mostra-se, além de mais longa, também a mais larga enquanto a raiz $\mathrm{C} 7$ apresenta-se igualmente como a mais curta. Por seu turno, SOUZA et al. (1985), para fetos de bovinos azebuados, citam que a raiz procedente do $5^{\circ}$ par cervical é, às vezes, delicada e mesmo inconstante, o que também observamos em algumas peças do nosso material.

Segundo o critério topográfico citado por LOCCHI (1932a) para identificação do sistema frênico-parafrênico, considera-se como raízes do nervo frênico principal as que se reúnem num tronco comum ao nível ou acima do tubérculo carotidiano, 
ao passo que todo filete nervoso, que segue independente até mais abaixo, unindo-se ao frênico na superfície externa do músculo escaleno, na base do pescoço, na entrada do tórax ou no tórax, seria designado nervo frênico acessório ou parafrênico. Deste modo, de acordo com nossos resultados, em ovinos da raça Santa Inês, a raiz procedente de C6 é a principal e portanto, reconhecida como nervo frênico principal ou propriamente dito (LOCCHI, 1932a) enquanto as raízes procedentes de C5 e C7 poderiam fazer o papel de nervo frênico acessório ou parafrênico (também segundo o mesmo autor). Outro fato que reforça nossa afirmação é que a raiz de C6 é constante na estrutura do nervo frênico em todas as preparações de nosso material, em ambos os antímeros.

Segundo nosso parecer, a designação de "parafrênico" é aceitável o que, entretanto, não acontece com a utilização do termo "acessório". De fato, tem-se como significado de "acessório", "aquilo que se acrescenta a alguma coisa sem dela, entretanto, fazer parte". Ora, os chamados nervos frênicos acessórios fazem parte do tronco do nervo frênico e tem seu correspondente território de inervação não nos parecendo, portanto, adequada tal denominação para identificá-los.

Já nos cães, conforme as descrições de DE TROYER et al. (1982); STEWART et al. (1983) e DALECK (1991), é o volume que identifica a raiz principal e C6 é a raiz mais calibrosa, sendo assim considerada o nervo frênico propriamente dito e C5, o nervo frênico acessório ou parafrênico; porém no gato e no macaco, a raiz mais calibrosa é C5 e, no homem, é C4. Talvez JEFFERSON et al. (1949) refiram-se a tal aspecto ao aludirem à presença de um nervo acessório em um cão, quando 19 meses após secção frênica esquerda, encontraram completa atrofia na metade anterolateral do hemidiafragma esquerdo enquanto a metade posterolateral, normal, apresentou-se, mediante dissecção, inervada por um contingente que não havia sido seccionado. Acreditamos que a esse fato seja coe- 
rente a alusão de WILSON (1970) de que após frenicotomia bilateral em gatos, observa-se a persistência de fibras nervosas nas zonas crurais e posterolaterais direita e esquerda no lado da secção, achados que levantam a possibilidade de fibras acessórias juntarem-se ao nervo frênico no terço periférico do seu curso. Também CONDE (1957) e FERRREIRA et al. (1973) descrevem ocorrência semelhante, apontando a presença de certos filetes denominados "acessórios" situados entre os troncos principais do nervo frênico de cães e ovinos da raça Corriedale, respectivamente.

No que tange aos níveis de união das raízes nervosas formadoras dos nervos frênicos, nossos resultados mostram que essas junções ocorrem, na maioria das vezes, sob a $1^{\underline{a}}$ costela e espaço intercostal correspondente, tanto à direita (86,66\%) como à esquerda (85,72\%), podendo também acontecer, em menor freqüência, em correspondência à articulação entre a $6^{\underline{a}}$ e $7^{\mathrm{a}}$ vértebras cervicais, à direita $(6,67 \%)$ e à esquerda (3,57\%) e em correspondência à articulação entre a $5^{\mathrm{a}}$ e $6^{\underline{a}}$ vértebras cervicais, à direita $(6,67 \%)$ e à esquerda $(10,71 \%)$, esse aspecto não foi assinalado pelos tratadistas nos Compêndios de Anatomia Veterinária, pois consoante informamos, esses autores provavelmente não se preocuparam com a origem dos nervos frênicos, mas apenas com as suas relações topográficas.

De outra parte, devemos informar que os dados ora obtidos, para ovinos da raça Santa Inês, no tocante aos níveis de origens das raízes nervosas que compõem os nervos frênicos, coincidem em parte com aqueles demonstrados por SOUZA et al. (1985) para fetos de bovinos azebuados, pois conforme esses autores, nesses animais, a união dos filetes nervosos formadores dos aludidos nervos não ocorre na região cervical mas sim, sob a $1^{\underline{a}}, 2^{\underline{a}}, 3^{\underline{a}}$ e $4^{\underline{a}}$ costelas e espaços intercostais correspondentes. Já DIAS et al. (1974) e TAMEGA et al. (1975) as- 
sinalam para cães e para gatos, respectivamente, essa junção ainda na região cervical, como por nós observado para ovinos da raça Santa Inês, porém em menor ocorrência, isto é, em 13,34\% das preparações à direita e em 14,28\% à esquerda. À essa união na região cervical, soma-se a junção dos filetes nervosos dentro da cavidade torácica, ou seja, a partir do $1^{1}$ par de costelas segundo relatos de DIAS et al. (1974) para cães, TAMEGA et al. (1975) para gatos e nossas observações em ovinos da raça Santa Inês, quando registramos esta ocorrência em $86,66 \%$ de nossas peças à direita e em $85,72 \%$ à esquerda.

Deste modo, esta variação nos níveis de união das raízes formadoras dos nervos frênicos, compreendendo o intervalo entre a 6 ${ }^{\underline{a}}$ vértebra cervical e $04^{\circ}$ par de costelas e espaços intercostais correspondentes, traduz-se num fato indicativo de que as abordagens destes nervos, para uma estimulação ou secção, devem ser feitas na cavidade torácica e aí, variando segundo a espécie, isto é, no caso de ovinos da raça Santa Inês e de gatos, segundo nossos resultados e os de TAMEGA et al. (1975), respectivamente, a partir do $1^{\circ}$ par de costelas e, de acordo com os relatos de DIAS et al. (1974) para cães e SOUZA et al. (1985) para fetos de bovinos azebuados, após o $4^{\circ}$ par de costelas. Assim, este procedimento evita observações parciais e incorretas, pela análise isolada de filetes formadores dos nervos frênicos.

Outro tópico a ser ressaltado é que em ovinos da raça Santa Inês, à semelhança do que ocorre em bubalinos (BAMEL et al., 1970), cães (DIAS et al., 1974) e fetos de bovinos azebuados (SOUZA et al., 1985), quando os nervos frênicos são formados a partir de três raízes, isto é, de C5, C6 e C7, os filetes nervosos procedentes dos ramos ventrais de $\mathrm{C} 6$ e $\mathrm{C} 7$ unem-se para formar um tronco que recebe a contribuição de $\mathrm{C} 5$ e este arranjo parece ser uma constante. Isso reforça nossa suposição de que a raiz de C5, em ovinos da raça Santa Inês, exerce o 
papel de nervo frênico acessório ou parafrênico comentado por LOCCHI (1932a) e já mencionado por nós neste capítulo. Surge, assim, a necessidade de melhor esclarecer este aspecto em animais de outras raças e mesmo de outras espécies, mediante estudos acurados.

Ao compararmos os nervos frênicos direito e esquerdo, no atinente ao número de raízes formadoras e ao nível de união dessas raízes, constatamos que não há diferença estatisticamente significante, quando confrontados os sexos, fato não mencionado pelos pesquisadores que abordaram o assunto em outras espécies.

Após estes comentários sobre os níveis de origem e de união dos filetes nervosos formadores dos nervos frênicos, passaremos agora a tecer considerações sobre alguns aspectos relacionados à divisão e distribuição dos nervos frênicos no diafragma de ovinos da raça Santa Inês.

Ao examinarmos as descrições contidas nos Tratados de Anatomia Veterinária, concernentes à divisão terminal dos nervos frênicos, verificamos que a maioria dos autores consultados, a exemplo de ZIMMERL (1909); LESBRE (1923); ELLENBERGER e BAUM (1932); GONZÁLEZ Y GARCIA e GONZÁLEZ ALVAREZ (1949) e SCHWARZE e SCHRÖDER (1972) comentam, de modo geral, que os nervos frênicos chegam ao centro frênico e se distribuem à porção carnosa, referência essa similar às exaradas, nesse sentido, por CHAUVEAU et al. (1905a); LESBRE (1923) e ZIMMERL (1930) ao mencionarem a presença de um ou mais filetes nervosos destinados aos pilares.

Da mesma forma, alguns autores dos trabalhos especializados que consultamos, apontam essa mesma disposição dos ramos terminais dos nervos frênicos descrita pelos tratadistas, quer tenham trabalhado com animais ruminantes, como 
nós, ou não. Assim, podemos citar em ruminantes: PANCRAZI (1925) em bovinos e outras espécies, LUTINICKI (1950) em ovinos, GIROLLA (1955) em bovinos, NEVES (1968) em fetos de bovinos, BAMEL et al., (1970) em búfalos, MIA (1973) em zebuínos, MIGLINO et al., (1985) em ovinos da raça Ideal e, em não ruminantes: FUNAOKA et al. (1930) apud BERTELLI (1933) em coelhos e cães, BERTELLI (1933) em coelhos, cobaias, ratos e cães neonatos, CONDE (1957) em cães, CONDE (1959) em suínos, SILVA et al. (1979) em gambás e SOUZA et al. (1987) em suínos da raça Landrace.

Entretanto, diferentemente desses autores, encontramos em ovinos da raça Santa Inês, os nervos frênicos alcançando não apenas a porção carnosa do diafragma, mas também os folíolos dorsais e ventral e a parede da veia cava caudal, do mesmo modo que alguns autores que pesquisaram o assunto em outros ruminantes, a saber: MIGLINO et al. $(1982,1985,1993)$ em caprinos, em búfalos da raça Jaffarabadi e em veados, SOUZA et al. (1984) em bovinos da raça Nelore, TOCANTINS NETO (1985) em búfalos da raça Murrah, PRADA et al. (1987) em ovinos deslanados e, em não ruminantes, outros autores fazem a mesma citação, como BERTELLI (1894) apud CONDE (1957) e BERTELLI (1895) em cães, FERREIRA et al. (1981) em ratões do banhado, SANTIAGO $(1982,1986)$ em eqüinos da raça Puro Sangue Inglês e sem raça definida, MIGLINO et al. (1986, 1988 , 1993) em tamanduás bandeira, capivaras e catetos, AMORIM JÚNIOR (1988) em jumentos nordestinos e CARVALHO et al. (1993) em cutias.

A inervação dessas estruturas (folíolos dorsais e ventral e veia cava caudal), pelos nervos frênicos leva-nos à reflexão a respeito da afirmativa de CHAUVEAU et al. (1905a); LESBRE (1923); ZIMMERL (1909, 1930); ANDREI (1928); ELLENBERGER e BAUM (1932); FONTES (1934); DOBBERSTEIN e HOFFMAN (1964); SCHWARZE e SCHRÖDER (1972); NICKEL et al. (1977) e DYCE et al. 
(1990) de que os nervos frênicos constituem a inervação motora do diafragma pois sabemos que o nervo frênico, como todo nervo misto, possui, além de fibras motoras (somáticas e viscerais), também fibras sensitivas (somáticas e viscerais). Talvez seja mais prudente a postura dos fisiologistas que, de modo geral consideram o nervo frênico como predominantemente motor, destacando assim a importante função que desempenha junto à porção carnosa do diafragma. Entretanto, nos folíolos nos quais não observamos, pelo menos macroscopicamente, fibras musculares (somáticas) e na parede da veia cava caudal, as funções motora e sensitiva (somática e visceral) dos focados nervos não devem ser esquecidas. É interessante lembrar aqui o trabalho de LOCCHI (1931) sobre o diafragma no Bradypus tridactylus no qual lemos: "Somente encontrei, em alguns casos, feixes musculares aberrantes, os quais se destacando do contorno esquerdo do orifício abdominal do canal, recobrem o tronco da artéria frênica inferior comum e vão espraiar-se na face abdominal do folíolo esquerdo do centro tendíneo; e, mais raramente, ainda notei feixes musculares que, partindo do canal, alcançam a veia cava, na sua parte infradiafragmática." O “canal” referido pelo Prof. LOCCHI é o "canal aorticoesophageano" presente no diafragma da espécie estudada. Também, OLIVEIRA et al. (1956) relatam ocorrência rara da presença de feixe muscular, medindo $6 \mathrm{~mm}$ de largura e 7 $\mathrm{mm}$ de comprimento, cruzando o folíolo dorsal esquerdo do centrum tendineum do diafragma de cão. Fazendo observações em série sobre a inervação do diafragma de ovinos da raça Santa Inês, deparamos de igual modo, com uma área muscular circular localizada no folíolo ventral do diafragma de um dos exemplares, fichado sob o $\mathrm{n}^{\circ} 27$ e de sexo masculino. O ramo esternal do nervo frênico esquerdo dirige-se à essa área muscular mencionada. Parece-nos recomendável, portanto, que pesquisas futuras, voltadas às considerações que fizemos, venham a esclarecê-las. 
No atinente à divisão terminal dos nervos frênicos em ovinos da raça Santa Inês, evidenciamos a presença constante de três ramos principais, de cada lado e designados à maneira de BERTELLI (1894, 1895 e 1933) de dorsal, lateral e ventral. Aliás, todos os pesquisadores que consignamos em nossa literatura concordam com tal disposição em seus achados, quer em animais ruminantes e não ruminantes e inclusive, valem-se da mesma nomenclatura, à exceção de PANSINI (1988) e FUNAOKA et al. (1930) apudBERTELLI (1933) e de AMORIM JÚNIOR (1988). Preferimos, considerando a natural disposição dos ramos terminais dos nervos frênicos nos diferentes segmentos da porção carnosa (pars lumbalis, pars costalis e pars sternalis), designá-los de, respectivamente, lombar, costal e esternal, da mesma forma que o adotado por AMORIM JÚNIOR (1988) para jumentos nordestinos. De modo geral, os tratadistas ZIMMERL (1909); LESBRE (1923); ELLENBERGER e BAUM (1932); GONZÁLEZ Y GARCÍA e GONZÁLEZ ALVAREZ (1949) e SCHWARZE e SCHRÖDER (1972) aludem à questão, ao considerarem que os nervos frênicos chegam ao centro frênico emitindo vários ramos ao diafragma, os quais inervam as porções correspondentes do mesmo.

Os três ramos apontados por nós e por todos os outros autores consultados, podem nascer do nervo frênico homolateral por trifurcação ou bifurcação, nesse caso com a formação de um tronco lombocostal ou costoesternal. Em nosso trabalho, mais freqüentemente registramos bifurcação à direita (40,00\%) com a presença de tronco lombocostal e ramo esternal, arranjo este que surge também como o mais comumente encontrado em outros ruminantes, segundo indicações de FERREIRA et al. (1973) em ovinos da raça Corriedale, MIGLINO et al. (1985) em búfalos da raça Jaffarabadi e PRADA et al. (1987) em ovinos deslanados, assim como em outras espécies, conforme relatos de BERTELLI (1933) e CONDE (1957) para cães, SILVA et al. (1979) para gambás, FERREIRA et al. (1981) 
para ratões do banhado, SANTIAGO $(1982,1986)$ para eqüinos da raça Puro Sangue Inglês e sem raça definida, MIGLINO et al. (1986) para tamanduás bandeira, AMORIM JÚNIOR $(1988,1993)$ em jumentos nordestinos e sagüis e CARVALHO et al. (1993) para cutias.

Por seu turno, essa modalidade não aparece como a maior ocorrência nas pesquisas de PANCRAZI (1925); GIROLLA (1955); NEVES (1968) e SOUZA et al. (1984) em bovinos, MIGLINO et al. $(1982,1985)$ em caprinos e ovinos da raça Ideal, TOCANTINS NETO (1985) em búfalos da raça Murrah, além de BERTELLI (1933) em coelhos, CONDE (1959) e SOUZA et al. (1987) em suínos, MIGLINO et al. $(1988,1993)$ em capivaras e catetos, MENDONÇA et al. (1993) em Colomys Calosus. Para esses animais, os autores referidos apresentam como disposição mais freqüente, relativamente ao nervo frênico direito, a formação de um ramo dorsal e um tronco ventrolateral (costoesternal, para nós), fato surpreendido em apenas duas de nossas preparações (6,67\%), dado que se aproxima do observado por PRADA et al. (1987) em ovinos deslanados (5,00\%) e AMORIM JÚNIOR et al. (1993) em sagüis (6,66\%) mas que aparece como a segunda maior ocorrência nos relatos de FERREIRA et al. (1973) para ovinos da raça Corriedale, MIGLINO et al. $(1985,1993)$ para búfalos da raça Jaffarabadi e veados, CONDE (1957) para cães, SILVA et al. (1979) para gambás, SANTIAGO (1986) para eqüinos sem raça definida e CARVALHO et al. (1993) para cutias.

Ainda em se tratando do nervo frênico direito, constatamos em 1/3 dos casos (33,33\%) a divisão por trifurcação. Tal arranjo é descrito por alguns autores consultados como a segunda maior ocorrência nas espécies estudadas, a exemplo de NEVES (1968) e SOUZA et al. (1984) em bovinos, MIGLINO et al. (1982, 1985) em caprinos e ovinos da raça Ideal, PRADA et al. (1987) em ovinos deslanados, CONDE (1959) e SOUZA et al. (1987) em suínos, SILVA et al. (1979) 
em gambás, FERREIRA et al. (1981) em ratões do banhado e AMORIM JÚNIOR et al. (1993) em sagüis. Outro grupo de pesquisadores também descreve essa modalidade de divisão, mas em menor freqüência, sendo o caso de FERREIRA et al. (1973) em ovinos da raça Corriedale, MIGLINO et al. (1985) e TOCANTINS NETO (1985) em búfalos das raças Jaffarabadi e Murrah, respectivamente, SANTIAGO (1986) em eqüinos sem raça definida e CARVALHO et al. (1993) em cutias. Porém, MIGLINO et al. (1993) informam que esse foi o arranjo de terminação mais encontrado em veados (45,00\%).

Em nossas peças, não registramos para o nervo frênico direito, a disposição em ramo ventral e tronco dorsolateral, aliás presente nas investigações de MIGLINO et al. $(1982,1985,1993)$ em caprinos $(27,50 \%)$, ovinos da raça Ideal $(30,00 \%)$ e veados $(18,20 \%)$, SOUZA et al. $(1984,1987)$ em bovinos da raça Nelore $(16,60 \%)$ e suínos da raça Landrace (7,50\%), TOCANTINS NETO (1985) em búfalos da raça Murrah (46,70\%) e MENDONÇA et al. (1993) em Colomys calosus (14,29\%), também não verificamos a divisão do nervo frênico direito em ramo dorsal, dois ramos costais e ramo ventral, conforme descrição de PRADA et al. (1987) para ovinos deslanados.

Por sua vez, nenhum dos pesquisadores citados refere-se a arranjos que surpreendemos em ovinos da raça Santa Inês, relativos à divisão do nervo frênico direito, sendo um deles, de divisão do nervo frênico em troncos lombocostal e costoesternal $(16,67 \%)$ e, o outro, em tronco lombocostal e ramos costal e esternal $(3,33 \%)$.

Focalizando, em seguida, a divisão do nervo frênico esquerdo, visualizamos com maior freqüência em ovinos da raça Santa Inês, a disposição em trifurcação (40,00\%), informação coincidente curiosamente, com apenas a de PRADA et al. (1987) relativa a ovinos deslanados $(45,00 \%)$ e a de AMORIM JÚNIOR et al. 
(1993), atinente a sagüis (40,00\%). Entretanto, esse arranjo em trifurcação foi o descrito em menor ocorrência nos trabalhos de CONDE $(1957,1959)$ em cães (15,00\%) e suínos (1,60\%), NEVES (1968) em fetos de bovinos $(10,00 \%)$, FERREIRA et al. $(1973,1981)$ em ovinos da raça Corriedale $(23,50 \%)$ e ratões do banhado (10,00\%), SILVA et al. (1979) em gambás (6,70\%), MIGLINO et al. $(1982,1985,1993)$ em caprinos $(12,50 \%)$, búfalos da raça Jaffarabadi $(13,30 \%)$, ovinos da raça Ideal $(20,00 \%)$ e veados $(18,20 \%)$, SANTIAGO $(1982,1986)$ em eqüinos da raça Puro Sangue Inglês $(6,60 \%)$ e eqüinos sem raça definida $(10,00 \%)$, SOUZA et al. $(1984,1987)$ em bovinos da raça Nelore $(30,00 \%)$ e suínos da raça Landrace (7,50\%) e CARVALHO et al. (1993) em cutias (23,50\%).

Ainda relativamente à terminação do nervo frênico esquerdo, encontramos como segunda ocorrência em nossas peças, a presença de ramo dorsal e tronco costoesternal (26,68\%), achado que aparece mais comumente nas pesquisas da maioria dos autores consultados, a saber: PANCRAZI (1925) em bovinos e outras espécies, GIROLLA (1955) em bovinos, CONDE (1959) em suínos (96,60\%), NEVES (1968) em fetos de bovinos (83,30\%), FERREIRA et al. (1981) em ratões do banhado $(50,00 \%)$, MIGLINO et al. $(1982,1985,1988,1993)$ em caprinos $(80,00 \%)$, em búfalos da raça Jaffarabadi $(86,60 \%)$, em capivaras $(73,30 \%)$, em catetos $(100,00 \%)$ e em veados $(54,50 \%)$, SANTIAGO $(1982,1986)$ em eqüinos da raça Puro Sangue Inglês $(66,70 \%)$ e eqüinos sem raça definida (80,00\%), SOUZA et al. $(1984,1987)$ em bovinos da raça Nelore $(60,00 \%)$ e suínos da raça Landrace (87,50\%), TOCANTINS NETO (1985) em búfalos da raça Murrah (100,00\%) e CARVALHO et al. (1993) em cutias (41,20\%). Outros trabalhos especializados descrevem esse arranjo em freqüências próximas às nossas, ou seja, FERREIRA et al. (1973) em ovinos da raça Corriedale (30,00\%), MIGLINO et al. (1985) em ovinos da raça Ideal (30,00\%), PRADA et al. (1987) em ovinos deslanados (25,00\%) e AMORIM JÚNIOR (1993) em sagüis (33,33\%). 
Apenas CONDE (1957) em cães (15,00\%) apresenta porcentagem dessa disposição em ramo dorsal e tronco costoesternal inferior à nossa, em ovinos da raça Santa Inês (26,68\%).

Continuando nossas observações sobre a divisão terminal do nervo frênico esquerdo, em ovinos da raça Santa Inês, identificamos uma terceira modalidade de apresentação do aludido nervo, resolvendo-se em tronco lombocostal e ramo esternal (20,00\%), arranjo igualmente exibido, em freqüências maiores, em cães (70,00\%) por CONDE (1957), em ovinos das raças Corriedale (40,00\%) e Ideal (50,00\%) por FERREIRA et al. (1973) e por MIGLINO et al. (1985), respectivamente, em gambás $(90,00 \%)$ por SILVA et al. (1974), em ratões do banhado (40,00\%) por FERREIRA et al. (1981), em ovinos deslanados (30,00\%) por PRADA et al. (1987) e em jumentos nordestinos (53,30\%) por AMORIM JÚNIOR (1988). Aproximando-se do observado por nós, em ovinos da raça Santa Inês, para esse arranjo de divisão do nervo frênico esquerdo em tronco lombocostal e ramo esternal (20,00\%), encontram-se os achados de SANTIAGO (1982) em eqüinos da raça Puro Sangue Inglês (26,70\%), AMORIM JÚNIOR et al. (1993) em sagüis (26,60\%), CARVALHO et al. (1993) em cutias (23,50\%) e MIGLINO et al. (1993) em veados (27,30\%). Do mesmo modo, essa disposição em bifurcação aparece, em porcentagens menores, nos resultados de NEVES (1968) em fetos de bovinos (6,60\%), MIGLINO (1982) em caprinos (7,50\%) e SOUZA et al. $(1984,1987)$ em bovinos da raça Nelore $(10,00 \%)$ e em suínos da raça Landrace $(5,00 \%)$.

Em poucas oportunidades (13,33\%) verificamos o nervo frênico esquerdo cedendo os ramos lombar, costal (em número de dois) e esternal, concomitantemente, em ovinos da raça Santa Inês. Relato semelhante é apresentado por PRADA et al. (1987) para ovinos deslanados. 
Mais raramente ainda, em nosso material, observamos o nervo frênico esquerdo dividindo-se nos troncos lombocostal e costoesternal (3,33\%), muito menos freqüente que o observado à direita (16,67\%) e em ramos lombar, costal e tronco costoesternal (3,33\%), modalidade não encontrada no nervo frênico direito. $\mathrm{Ne}$ nhuma das pesquisas consultadas apresenta essas disposições nos seus resultados. Entretanto, SILVA et al. (1979) refere-se a outro arranjo que não constatamos em ovinos da raça Santa Inês, isto é, a terminação do nervo frênico em tronco ventrodorsal e ramo lateral, reconhecida em gambás (3,30\%).

Considerando-se agora os ramos terminais dos nervos frênicos direito e esquerdo, em conjunto, verificamos distribuição simétrica em ovinos da raça Santa Inês, em 36,67\% dos casos. Assim, descrevemos divisão por trifurcação, resultando os ramos lombar, costal e esternal em parte delas (16,67\%), fato também evidenciado por outros autores, porém em porcentagens menores, como MIGLINO et al. $(1982,1985)$ em caprinos $(7,50 \%)$ e ovinos da raça Ideal $(10,00 \%)$, SANTIAGO (1986) em eqüinos sem raça definida (4,00\%), PRADA et al.(1987) em ovinos deslanados (10,00\%), CARVALHO et al. (1993) em cutias (5,90\%) e ainda por AMORIM JÚNOR et al. (1993) em freqüência maior, em sagüis (20,00\%)

Verificamos a formação de tronco lombocostal e ramo esternal em algumas preparações (10,0\%), arranjo igualmente descrito mas, em freqüências diferentes, por SILVA et al. (1979) em gambás (70,00\%), MIGLINO et al.(1982, 1985) em caprinos $(2,50 \%)$ e ovinos da raça Ideal $(20,00 \%)$, SANTIAGO $(1982,1986)$ em eqüinos da raça Puro Sangue Inglês (26,70\%) e sem raça definida (10,00\%), PRADA et al. (1987) em ovinos deslanados (5,00\%), AMORIM JÚNIOR et al. (1993) em sagüis (33,33\%) e CARVALHO et al. (1993) em cutias (23,54\%). 
Ainda, no atinente aos ramos terminais dos nervos frênicos, considerados simultaneamente, surpreendemos a presença de ramo lombar e tronco costoesternal em apenas duas oportunidades $(6,67 \%)$ de nosso material em ovinos da raça Santa Inês, relato que se distancia muito daqueles apresentados por NEVES (1968) para fetos de bovinos $(76,60 \%)$, MIGLINO et al. $(1982,1985,1988)$ para caprinos $(35,00 \%)$, búfalos da raça Jaffarabadi $(46,60 \%)$, ovinos da raça Ideal (20,00\%) e capivaras (73,30\%), TOCANTINS NETO (1985) para búfalos da raça Murrah (40,00\%), SOUZA et al. (1987) para suínos da raça Landrace $(72,50 \%)$ e CARVALHO et al. (1993) para cutias (11,80\%). De outra parte, essa modalidade de divisão aparece, menos freqüentemente, segundo os resultados apresentados por SANTIAGO $(1982,1986)$ em eqüinos da raça Puro Sangue Inglês $(3$, $30 \%)$ e sem raça definida $(4,00 \%)$.

Outro arranjo encontrado por nós para os nervos frênicos em conjunto, em rara oportunidade (3,33\%), é a divisão em troncos lombocostal e costoesternal, achado não descrito pelos autores pesquisados.

Continuando a observação dos ramos terminais dos nervos frênicos direito e esquerdo, em conjunto, vimos disposições assimétricas em $63,33 \%$ das dissecações, ou seja, respectivamente à direita e à esquerda: tronco lombocostal e ramo esternal mais ramos lombar, costal e esternal (16,67\%); ramos lombar, costal e esternal mais ramo lombar e tronco costoesternal (10,00\%); tronco lombocostal e ramo esternal mais ramo lombar e tronco costoesternal (10,00\%); ramos lombar, costal e esternal mais tronco lombocostal e ramo esternal (6,67\%); troncos lombocostal e costoesternal mais ramos lombar, costal ( em número de dois) e esternal (6,67\%); tronco lombocostal e ramos costal e esternal mais ramos lombar, costal (em número de dois) e esternal (3,33\%); troncos lombocostal e costoesternal mais ramos lombar, costal e esternal $(3,33 \%)$; troncos lombocostal 
e costoesternal mais tronco lombocostal e ramo esternal $(3,33 \%)$ e, finalmente, tronco lombocostal e ramo esternal mais ramos lombar, costal (em número de 2) e esternal (3,33\%). Apenas três desses arranjos, considerando conjuntamente os nervos frênicos direito e esquerdo, são especificados por dois autores consultados, ou seja, MIGLINO et al. (1985) que, para búfalos da raça Jaffarabadi mencionaram a ocorrência, respectivamente à direita e à esquerda, de tronco dorsolateral e ramo ventral mais trifurcação em ramos dorsal, lateral e ventral (5,00\%) e TOCANTINS NETO (1985) que, para búfalos da raça Murrah cita as disposições, respectivamente à direita e à esquerda, de ramo ventral e tronco dorsolateral mais ramo dorsal e tronco ventrolateral $(50,00 \%)$ e de ramos dorsal, lateral e ventral mais ramo dorsal e tronco ventrolateral $(10,00 \%)$. Os demais trabalhos pesquisados nada aludem sobre tais modalidades de divisão.

Frente a essas marcantes diferenças, não encontramos justificativas para a ocorrência dos diferentes tipos de distribuição dos nervos frênicos nos animais considerados. Apenas, podemos confirmar a afirmativa de PANCRAZI (1925) de que a divisão dos nervos frênicos varia segundo a espécie e entre representantes da mesma espécie e, tudo ocorrendo ao acaso.

Atentando, separadamente, para cada um dos ramos terminais dos nervos frênicos, isto é, lombar, costal e esternal, lembramos que essas expressões correspondem, respectivamente, às designações dorsal, lateral e ventral utilizadas pela maioria dos autores listados.

Assim, quanto à distribuição dos nervos frênicos no diafragma de ovinos da raça Santa Inês, encontramos de modo geral, em concordância com todos os autores consignados, os ramos lombares direitos distribuindo-se na pars 
lumbalis. Certamente essa observação é concordante com a de alguns tratadistas como CHAUVEAU et al. (1905a) e LESBRE (1923) que se referem à presença de fino ramo dirigido aos pilares, afirmação que se assemelha à exarada por ZIMMERL (1930), segundo o qual um ou mais filetes nervosos são destinados exclusivamente a eles. Entretanto, ao contrário do observado por BERTELLI $(1895,1933)$ em cães, PANCRAZI (1925) em bovinos e outras espécies, BAMEL et al. (1970) em búfalos, MIA (1973) em zebuínos, MIGLINO et al. (1985) em ovinos da raça Ideal, que descrevem os ramos lombares dirigindo-se exclusivamente à pars lumbalis nas espécies trabalhadas, evidenciamos os citados ramos destinando-se apenas à referida pars lumbalis, em somente $46,67 \%$ dos casos. Este nosso achado está coerente com o especificado por alguns pesquisadores, a exemplo de CONDE $(1957,1959)$ para cães $(92,50 \%)$ e para suínos (91,60\%), NEVES (1968) para fetos de bovinos (96,60\%), SILVA et al. (1979) para gambás (33,30\%), MIGLINO (1982) para caprinos (50,00\%), SANTIAGO (1982) para eqüinos da raça Puro Sangue Inglês (83,30\%), SOUZA et al. (1984) para bovinos da raça Nelore (70,00\%), MIGLINO et al. (1985) para búfalos da raça Jaffarabadi (26,60\%), TOCANTINS NETO (1985) para búfalos da raça Murrah (73,30\%), PRADA et al. (1987) para ovinos deslanados (95,00\%), SOUZA et al. (1987) para suínos da raça Landrace (90,00\%) e AMORIM JÚNIOR (1988) para jumentos nordestinos $(86,70 \%)$.

Prosseguindo nossos comentários sobre o comportamento do ramo lombar direito, encontramo-lo dirigindo-se, concomitantemente, à pars lumbalis direita e à veia cava caudal em metade das preparações $(50,00 \%)$, fato também salientado, em menores proporções, por MIGLINO $(1982,1985,1993)$ em caprinos (25,00\%), em búfalos da raça Jaffarabadi $(40,00 \%)$ e em veados $(22,00 \%)$, SOUZA et al. (1984) em bovinos da raça Nelore $(30,00 \%)$ e TOCANTINS NETO (1985) em búfalos da raça Murrah (20,00\%). Em apenas uma ocasião (3,33\%), 
verificamos que o ramo lombar direito distribui-se, simultaneamente, no pilar homólogo, veia cava caudal e folíolo dorsal direito, ocorrência apontada por TOCANTINS NETO (1985) em igual porcentagem (3,30\%) para búfalos da raça Murrah e, também, em diferentes freqüências por MIGLINO et al. (1982, 1985, 1988 ) em caprinos (10,00\%), búfalos da raça Jaffarabadi $(40,00 \%)$ e capivaras $(40,00 \%)$.

No que diz respeito, ainda, ao ramo lombar direito, CONDE (1957) em cães, NEVES (1968) em fetos de bovinos, SILVA et al. (1979) em gambás, TOCANTINS NETO (1985) em búfalos da raça Murrah e MIGLINO et al. (1993) em veados, indicam-no a distribuir-se na região lombar direita e na parte costal direita, enquanto MIGLINO et al. (1985) para búfalos da raça Jaffarabadi, acrescentam o relato de distribuição no pilar direito, porção costal direita, veia cava caudal e folíolo dorsal direito, disposições não evidenciadas em nossos resultados, como nos de outros autores relacionados que trabalharam com animais ruminantes ou não. Destaque-se, contudo, o achado de GIROLLA (1955) em um caso (feto de bovino), em que o ramo dorsal direito é visto a emitir filete que penetra na parte costal direita.

Do mesmo modo, não registramos para o ramo lombar direito em nossas observações, o arranjo descrito por MIGLINO et al. $(1982,1993)$ para caprinos e veados, PRADA et al. (1987) em ovinos deslanados, SANTIAGO $(1982,1986)$ para eqüinos da raça Puro Sangue Inglês e sem raça definida, SOUZA et al. (1987) para suínos da raça Landrace, AMORIM JÚNIOR (1988) para jumentos nordestinos e CARVALHO et al. (1993) para cutias, nos quais o ramo lombar direito inerva, além da parte lombar direita, também o folíolo dorsal direito. Curiosamente, CONDE (1959) para suínos cita uma distribuição diferente para o ramo lombar direito, ou seja, dirigindo-se não somente, à região lombar direita mas 
também à região esternal, disposição registrada em pequena proporção $(1,6 \%)$, porém não mencionada pelos pesquisadores consultados, nem identificada em nosso material (ovinos da raça Santa Inês). Da mesma maneira, aquela modalidade encontrada por AMORIM JÚNIOR (1988) em jumentos nordestinos, em que o ramo lombar direito alcança, simultaneamente, o pilar direito e o folíolo ventral em $3,30 \%$ dos casos, também não é mencionada.

A seu turno, analisando a seguir, a distribuição do ramo lombar esquerdo em ovinos da raça Santa Inês, vimo-lo sempre a inervar a parte lombar esquerda, tal como descrevem todos os autores compilados. Esta também parece ser a opinião dos tratadistas que referimos com respeito ao ramo lombar direito tais sejam CHAUVEAU et al. (1905a); LESBRE (1923) e ZIMMERL (1930). Casualmente, porém, filetes do ramo lombar esquerdo atingem outras partes do diafragma, formando assim, diferentes arranjos, mais precisamente: o ramo lombar esquerdo distribuindo-se somente na parte lombar homolateral, em 96,67\% dos nossos casos, dado que se aproxima dos relatos em outros ruminantes, como os exarados por MIGLINO et al. $(1982,1985)$ em caprinos $(75,00 \%)$, búfalos da raça Jaffarabadi $(73,30 \%)$ e ovinos da raça Ideal (100,00\%), TOCANTINS NETO (1985) em búfalos da raça Murrah (76,70\%) e PRADA et al. (1987) em ovinos deslanados (100,00\%). Entretanto, esses dados diferem daqueles emitidos por NEVES (1968) para fetos de bovinos (20,00\%) e SOUZA et al. (1984) para bovinos da raça Nelore $(26,70 \%)$.

Essa mesma disposição é encontrada em espécies de não ruminantes, em variadas proporções, conforme descrições de: $\operatorname{BERTELLI~}(1895,1933)$ em cães (100,00\%), CONDE $(1957,1959)$ em cães $(85,00 \%)$ e em suínos $(73,30 \%)$, SILVA et al. (1979) em gambás (50,00\%), SANTIAGO (1982) em eqüinos da raça Puro Sangue Inglês (86,60\%), SOUZA et al. (1987) em suínos da raça Landrace 
(65,00\%), AMORIM JÚNIOR (1988) em jumentos nordestinos (73,30\%) e MIGLINO et al. (1993) em catetos (25,00\%).

Em apenas uma oportunidade (3,33\%), surpreendemos o ramo lombar esquerdo distribuindo-se na parte lombar esquerda e folíolo dorsal esquerdo, como também descrito, em proporção semelhante por MIGLINO et al. (1985) para búfalos da raça Jaffarabadi (3,30\%) e em freqüências bem maiores por MIGLINO et al. (1982, 1993) para caprinos (12,50\%) e veados (27,30\%). Da mesma forma, evidenciamos o relatado para outras espécies não ruminantes nos trabalhos de SANTIAGO (1986) em eqüinos sem raça definida (12,00\%), AMORIM JÚNIOR (1988) em jumentos nordestinos (13,30\%) e CARVALHO et al. (1993) em cutias $(64,70 \%)$.

Outros arranjos, para o ramo lombar esquerdo, foram encontrados pelos diversos autores listados, nas diferentes espécies estudadas mas não foram visualizados em nossa investigação. Assim, CONDE (1957) em cães (7,50\%), NEVES (1968) em fetos de bovinos (3,30\%), SILVA et al. (1979) em gambás (50,00\%) e MIGLINO et al. (1993) em veados (11,10\%) descrevem a distribuição do ramo lombar esquerdo no pilar correspondente e na região dorsal da parte costal. Já, SANTIAGO (1982) para eqüinos da raça Puro Sangue Inglês (6,60\%) comenta sobre o arranjo de distribuição no pilar esquerdo e na veia cava caudal, enquanto AMORIM JÚNIOR (1988) em jumentos nordestinos (6,60\%) encontra para o aludido ramo, a distribuição no pilar esquerdo e folíolo ventral.

Cumpre-nos informar que casos de distribuição heterolateral dos ramos lombares dos nervos frênicos direito e esquerdo não foram observados por nós, em ovinos da raça Santa Inês como também não o foram por BAMEL et al. (1970) em búfalos, MIGLINO et al. (1985) em ovinos da raça Ideal e PRADA et al. (1987) em ovinos deslanados, entre ruminantes. A mesma observação é feita, entre 
espécies não ruminantes, por BERTELLI $(1895,1933)$ em cães, SILVA et al. (1979) em gambás, SANTIAGO (1982) em eqüinos da raça Puro Sangue Inglês e CARVALHO et al. (1993) em cutias. Porém, outros autores citam a ocorrência de inervação contralateral, fato que comentaremos mais adiante.

No relativo à distribuição do ramo costal direito no diafragma de ovinos da raça Santa Inês, notamo-lo, geralmente, a ramificar-se na pars costalis correspondente. Aliás, diversos autores afirmam que esse ramo inerva, unicamente, o referido território em outras espécies de ruminantes estudadas, como PANCRAZI (1925) em bovinos e outras espécies, GIROLLA (1955); NEVES (1968) e SOUZA et al. (1984) em bovinos, BAMEL et al. (1970) em búfalos e MIGLINO et al. $(1985,1987,1993)$ em ovinos e veados, sendo o mesmo afirmado por BERTELLI $(1985,1933)$ para cães, CONDE (1959) para suínos e MIGLINO et al. (1988) para capivaras. Esse acontecimento em que surpreendemos o ramo costal direito alcançando exclusivamente as regiões dorsal e ventral da pars costalis, ocorre em apenas $77,67 \%$ de nossas dissecações, descrição próxima à de TOCANTINS NETO (1985) para búfalos da raça Murrah (93,30\%). Por sua vez, o ramo costal direito visto a inervar toda a parte costal direita, como registrado por nós e por TOCANTINS NETO, é assinalado em freqüências menores por MIGLINO et al. (1982, 1985), para caprinos $(10,00 \%)$ e búfalos da raça Jaffarabadi (26,60\%), por SILVA et al. (1979) para gambás $(3,30 \%)$ e por AMORIM JÚNIOR (1988) para jumentos nordestinos (3,30\%). Ressaltamos que, para esses autores, a ocorrência maior de distribuição do ramo costal direito é nas porções dorsal e lateral da parte costal, conforme considerado por eles, sendo o mesmo referido pelos outros autores que identificaram esse ramo distribuindo-se apenas na parte costal, embora tenhamos empregado critério diferente daquele utilizado por esses pesquisadores na delimitação das regiões dorsal e ventral da pars costalis. 
Vale salientar, todavia, o arranjo incomum, somente por nós encontrado, no qual o ramo costal direito distribui-se nas regiões dorsal e ventral da pars costalis, emitindo ainda, filete nervoso ao folíolo ventral em $23,33 \%$ das peças. Essa disposição inusitada não é anotada pelos demais autores, nem mesmo por aqueles que pesquisaram o aludido ramo em ruminantes, como nós. Para MIGLINO et al. (1982, 1985, 1993) em caprinos $(30,00 \%)$, búfalos da raça Jaffarabadi $(6,60 \%)$ e catetos $(50,00 \%)$, TOCANTINS NETO (1985) em búfalos da raça Murrah $(6,70 \%)$, SANTIAGO $(1982,1986)$ em eqüinos da raça Puro Sangue Inglês $(20,00 \%)$ e sem raça definida (20,00\%) e AMORIM JÚNIOR (1988) em jumentos nordestinos, o ramo costal direito dirige-se, além da parte costal, ao folíolo dorsal e não ao ventral como o assinalado para nossas peças.

Porém, CONDE (1957) para cães (5,00\%), SILVA et al. (1979) para gambás $(3,30 \%)$, SANTIAGO $(1982,1986)$ para eqüinos da raça Puro Sangue Inglês $(23,30 \%)$ e sem raça definida (4,00\%) e CARVALHO et al. (1993) para cutias $(17,60 \%)$ descrevem arranjo diferente dos descritos anteriormente para o ramo costal direito, ou seja, assinalam-no dirigindo-se, concomitantemente, às partes costal e lombar. Da mesma forma, MIGLINO et al. $(1982,1988)$ para caprinos $(2,50 \%)$ e capivaras ( 1 vez) mencionam disposição única, isto é, o focado ramo alcançando a parte costal e veia cava caudal, simultaneamente. Essas duas últimas modalidades de distribuição não foram reconhecidas em ovinos da raça Santa Inês.

Passando ao ramo costal esquerdo, em sua ramificação no diafragma de ovinos da raça Santa Inês, consignamo-lo, em todas as oportunidades, orientado à pars costalis esquerda, como ressalta a maioria dos estudiosos do assunto. De fato, ao estudarmos tal ramo, verificamos sua distribuição exclusiva à aludida região em $90,00 \%$ das peças, freqüência próxima da apontada, para outros ruminan- 
tes, ou seja, por NEVES (1968) para fetos de bovinos (96,60\%), MIGLINO et al. $(1982,1985)$ para caprinos $(77,50 \%)$ e búfalos da raça Jaffarabadi $(96,70 \%)$, SOUZA et al. (1984) para bovinos da raça Nelore (90,00\%) e TOCANTINS NETO (1985) para búfalos da raça Murrah (100,00\%). Para outras espécies não ruminantes, referem-se de modo semelhante CONDE $(1957,1959)$ para cães (92,50\%) e suínos (95,00\%), SILVA et al. (1979) para gambás (90,00\%), SANTIAGO $(1982,1986)$ para eqüinos da raça Puro Sangue Inglês $(90,00 \%)$ e sem raça definida (80,00\%) e AMORIM JÚNIOR (1988) para jumentos nordestinos $(90,00 \%)$.

Entretanto, desses estudiosos nominados, apenas MIGLINO et al. $(1982,1985)$ para caprinos $(30,00 \%)$ e búfalos da raça Jaffarabadi $(43,30 \%)$, TOCANTINS NETO (1985) para búfalos da raça Murrah (100,00\%) e SANTIAGO (1982) para eqüinos da raça Puro Sangue Inglês $(6,60 \%)$ fazem menção ao ramo costal esquerdo como responsável pela inervação da porção ventral da parte costal como o descrito por nós em todas as observações em ovinos da raça Santa Inês. Talvez esse arranjo de distribuição diferenciado deva-se ao fato de termos utilizado critério diferente da maioria dos pesquisadores na delimitação das regiões dorsal e ventral da pars costalis, conforme já especificado para o ramo costal direito. Segundo esse critério, toma-se como limite linha horizontal imaginária tangente à terminação ventral dos pilares.

Ainda quanto à distribuição do ramo costal esquerdo, verificamos em alguns casos $(10,00 \%)$ que esse ramo pode enviar filetes ao folíolo ventral, todavia, em proporção inferior ao correspondente ramo direito (23,33\%). Esse arranjo não é mencionado por nenhum dos estudiosos compulsados, que por outro lado, correlacionam o ramo costal esquerdo com outras estruturas, além da porção costal homolateral, ou seja, a distribuir-se também no folíolo dorsal, de acordo 
com os relatos de MIGLINO et al. $(1982,1985,1993)$ para caprinos $(17,50 \%)$, búfalos da raça Jaffarabadi (3,30\%) e catetos (50,00\%), SANTIAGO $(1982,1986)$ para eqüinos da raça Puro Sangue Inglês (3,30\%) e sem raça definida $(20,00 \%)$ e AMORIM JÚNIOR (1988) para jumentos nordestinos (10,00\%). Já outro grupo de autores, em suas narrativas, comenta a distribuição do ramo costal esquerdo que se faz, simultaneamente, nas partes costal e lombar homolaterais, ou seja, CONDE $(1957,1959)$ para cães $(5,00 \%)$ e suínos $(5,00 \%)$, SILVA et al. (1979) para gambás $(10,00 \%)$, SOUZA et al. (1984) para bovinos da raça Nelore $(10,00 \%)$ e CARVALHO et al. (1993) para cutias $(35,30 \%)$, modalidades apresentadas somente por esses autores.

Prosseguindo na descrição dos aludidos nervos, lembramos que em alguns casos de ovinos da raça Santa Inês $(43,33 \%)$ notamos a presença de dois ramos costais à direita $(23,33 \%)$ e à esquerda $(20,00 \%)$, observação que, quiçá, corresponda a ramos "acessórios" dos nervos frênicos, referidos por um certo número de autores relacionados, inclusive LOCCHI (1932b).

Por fim, ocorrência de distribuição heterolateral dos ramos costais dos nervos frênicos direito e esquerdo não foi observada em nosso material, dado concordante com todos os estudiosos listados que trabalharam com ruminantes ou não.

Estudando a seguir a distribuição do ramo esternal direito (correspondente ao ramo ventral dos trabalhos dos demais autores compulsados) deparamos em ovinos da raça Santa Inês com o referido ramo emitindo filetes sempre e somente à pars sternalis e região ventral da pars costalis $(100,00 \%)$, dado coincidente com aqueles apresentados para outros ruminantes ou seja, por PANCRAZI (1925) para bovinos e outras espécies e MIGLINO et al. $(1985,1993)$ para ovinos da raça Ideal e veados, assim como o evidenciado em outras espécies de não ru- 
minantes, isto é, por BERTELLI $(1985,1933)$ em cães, CONDE (1959) em suínos, SILVA et al. (1979) em gambás e CARVALHO et al. (1993) em cutias.

Cabe aqui uma consideração. No presente trabalho, valemo-nos para definir a parte esternal, da inserção da porção mais ventral do diafragma, na cartilagem xifóide do esterno, indubitavelmente separada da parte costal, observação essa, efetuada em ovinos da raça Santa Inês com facilidade. A região limítrofe entre a parte esternal e a parte costal, que evidenciamos, corresponde ao espaço sem reforço muscular que certamente é referido em alguns Tratados de Anatomia Humana, a exemplo de GRAY et al. (1972) apud AMORIM JÚNIOR (1988), como sítio de potencial hérnia congênita retroesternal através do hiato muscular, a cada lado do processo xifóide.

Além desse único arranjo, descrito por nós, em ovinos da raça Santa Inês, alguns autores encontraram também outras modalidades de distribuição para o ramo esternal direito, ou seja: a inervar exclusivamente a parte esternal, arrajo observado por BAMEL et al. (1970) em búfalos, MIA (1974) em zebuínos, MIGLINO et al. (1982) em caprinos, SANTIAGO (1982) em eqüinos da raça Puro Sangue Inglês e SOUZA et al. (1984) em bovinos da raça Nelore; filetes endereçados à região dorsal da parte costal, disposição registrada por MIGLINO et al. $(1982,1985)$ para caprinos e búfalos da raça Jaffarabadi; filetes destinados somente à região ventral da parte costal, comportamento verificado por TOCANTINS NETO (1985) em búfalos da raça Murrah e PRADA et al. (1987) em ovinos deslanados; filetes alcançando o folíolo ventral, arranjo evidenciado por MIGLINO et al. (1982) em caprinos, TOCANTINS NETO (1985) em búfalos da raça Murrah, SANTIAGO $(1982,1986)$ em eqüinos da raça Puro Sangue Inglês e sem raça definida e AMORIM JÚNIOR (1988) em jumentos nordestinos; ramos dirigidos à veia cava caudal, disposição encontrada por MIGLINO (1982) em caprinos, SAN- 
TIAGO $(1982,1986)$ em eqüinos da raça Puro Sangue Inglês e sem raça definida e AMORIM JÚNIOR (1988) em jumentos nordestinos. MIGLINO et al. (1993) em catetos, também observam a ocorrência de filetes endereçados ao folíolo dorsal, do mesmo modo que SANTIAGO (1982) em eqüinos da raça Puro Sangue Inglês, que ainda, surpreende nesses espécimes, a presença de dois ramos esternais, à direita .

Analisando a distribuição do ramo esternal esquerdo, achamo-lo, mais freqüentemente $(83,33 \%)$, a distribuir-se na pars sternalis e região ventral da pars costalis homóloga do diafragma, achado também apontado pela maioria dos autores compulsados, quer tenham estudado o tema em ruminantes, como NEVES (1968) em fetos de bovinos (86,60\%), MIA (1973) em zebuínos (100,00\%), MIGLINO et al. (1982, 1985, 1993) em caprinos (50,00\%), em ovinos da raça Ideal (90,00\%) e em veados (100,00\%), TOCANTINS NETO (1985) em búfalos da raça Murrah e PRADA et al. (1987) em ovinos deslanados, quer tenham pesquisados o assunto em outros grupos de animais, a exemplo de BERTELLI $(1895,1933)$ em cães $(100,00 \%)$, CONDE $(1957,1959)$ em cães (95,00\%) e suínos (95,00\%), SILVA et al. (1979) em gambás (100,00\%), SANTIAGO $(1982,1986)$ em eqüinos da raça Puro Sangue Inglês $(86,60 \%)$ e sem raça definida (88,00\%), AMORIM JÚNIOR (1988) em jumentos nordestinos (100,00\%), MIGLINO et al. (1988) em capivaras (93,20\%) e CARVALHO et al. (1993) em cutias $(100,00 \%)$.

Todavia, em alguns casos $(16,67 \%)$ do nosso material, registramos o ramo esternal esquerdo a distribuir-se em outras regiões e/ou estruturas. Assim, em duas oportunidades $(6,67 \%)$, notamos o aludido ramo distribuindo-se somente na pars sternalis do diafragma, relato semelhante àquele apresentado por BAMEL et al. (1970) para búfalos, SOUZA et al. (1984) para bovinos da raça Nelore e 
SANTIAGO (1982) para eqüinos da raça Puro Sangue Inglês; em duas peças $(6,67 \%)$ observamos esse ramo enviando filetes ao folíolo ventral, tal como informam-nos MIGLINO (1982) para caprinos, TOCANTINS NETO (1985) para búfalos da raça Murrah e SANTIAGO (1982) para eqüinos da raça Puro Sangue Inglês.

Diferentemente da maioria dos trabalhos consultados, LOCCHI (1931) em Bradypus tridactylus e OLIVEIRA et al. (1956) em cães, encontraram em seus estudos feixes musculares aberrantes no centro tendíneo do diafragma. Nós também surpreendemos, em uma peça (3,33\%), o ramo esternal esquerdo emitindo filete nervoso para uma pequena área muscular circular localizada no folíolo ventral, aspecto já comentado anteriormente e que também é mencionado por MIGLINO et al. (1993) para veados. Estes últimos autores descrevem que apenas em um caso, ocorre um grupo de fibras musculares no folíolo ventral inervadas por filete derivado do ramo ventral.

Continuando a descrição do ramo esternal esquerdo observamos, nas pesquisas de MIGLINO (1982) em caprinos e PRADA et al. (1987) em ovinos deslanados, que esse ramo pode destinar-se exclusivamente à parte costal do diafragma $\mathrm{e}$ também enviar ramos à região dorsal desse território, como o encontrado por MIGLINO (1982) em caprinos, arranjos não descritos pelos outros autores pesquisados, nem por nós, em ovinos da raça Santa Inês.

Do mesmo modo que o observado para os outros ramos terminais dos nervos frênicos direito e esquerdo, ou seja, lombares e costais, não visualizamos em nossas peças distribuição heterolateral dos ramos esternais. Entretanto, essa ocorrência é apontada em outros ruminantes, tanto à direita como à esquerda, ou seja, por MIGLINO et al. $(1982,1985)$ em caprinos, búfalos da raça Jaffarabadi 
e ovinos da raça Ideal e, ainda, por CONDE (1957) em cães. Somente à esquerda relatam-nos GIROLLA (1955) para bovinos, TOCANTINS NETO (1985) para búfalos da raça Murrah, PRADA et al. (1987) para ovinos deslanados, assim como CONDE (1959) para suínos e SANTIAGO (1982) para eqüinos da raça Puro Sangue Inglês.

Gostaríamos ainda de fazer referência à essa ocorrência de inervação contralateral de ramos do nervo frênico, encontrada nas espécies trabalhadas por esses autores, anteriormente listados e, também, observada por: PANCRAZI (1925), que cita a ocorrência de alguns filetes originados do ramo dorsal esquerdo, atingindo o pilar direito do diafragma de bovinos e de outras espécies; ANDREI (1928) que encontra, ao exame histológico da musculatura do diafragma de cães, fibras musculares normais no meio do músculo atrofiado e, ao contrário, do lado normal, a presença de algumas fibras atrofiadas, acrescentando que esse fato se deve ao entrecruzamento de feixes musculares na linha mediana ao nível dos pilares lombares; FONTES (1934), que revela que, à excitação de um dos frênicos, os dois hemidiafragmas não reagem sempre da mesma maneira, respondendo ambos, algumas vezes, à excitação do frênico de um só lado; CARDIN et al. (1937), que relatam permanecerem, na região do pilar, mais precisamente em torno do orifício de passagem da aorta e esôfago, alguns fascículos musculares em estado de trofismo mais ou menos conservado, descrevendo, além disso, pequeno fascículo que do pilar de um lado se entrelaça ao pilar oposto, funcionando como um esfíncter em relação à aorta e ao esôfago; LUTNICKI (1950), que comenta sobre um quarto ramo dorsal esquerdo, passando para o lado direito do diafragma de ovino, contornando o esôfago; ainda LUTNICKI (1953), que aponta o ramo dorsal esquerdo contribuindo com a inervação da crus mediale destrum em suínos; BOTHA (1957), que através de estimulação farádica do nervo frênico de cães observou, em alguns animais, que o estímulo do ramo 
póstero-lateral, após seç̧ão do tronco principal, sempre provocava contração de todos os feixes musculares dos pilares do lado ipsilateral do hiato esofágico; MIA (1973), que se refere à inervação heterolateral dada pelos ramos dorsais em zebuínos; MIGLINO et al. (1993), que relatam ocorrer inervação heterolateral dada por filete do ramo dorsal direito, endereçado à parte lombar oposta, do diafragma de veados.

Embora esses autores citem entrecruzamento de fibras, SCHLAEPFER (1925) mostra na porção lombar, lateral e posteriormente ao esôfago, o diafragma de cão, do lado paralisado, completamente fibroso, julgando, por essa razão, serem improcedentes, as informações, freqüentemente encontradas, de que fibras musculares da porção lombar de um lado cruzam por trás do esôfago para 0 lado oposto. Também DE TROYER et al. (1982) não detectaram resposta à estimulação cruzada na linha mediana. Do mesmo modo, DALECK (1991) não encontra inervação contralateral, em cães, uma vez que as regiões atrofiadas da porção carnosa do diafragma, conseqüentes às radicotomias seletivas efetuadas, foram sempre unilaterais.

De nossa parte, os resultados obtidos não confirmam dados da literatura concernentes à ocorrência de inervação contralateral, uma vez que a distribuição dos nervos frênicos direito e esquerdo, em ovinos da raça Santa Inês, é exclusivamente homolateral, o que talvez coincida com os achados de JANSEN (1931) apudMIGLINO (1982), em estudo experimental dos nervos frênicos em caprinos, em que demonstra claramente que a secção de um deles determina a degeneração da metade correspondente do diafragma e reforça a informação de BAMEL et al. (1970) sobre a ausência de inervação cruzada no referido músculo, em búfalos. 
Aliás, a possibilidade de inervação contralateral pelos ramos lombar e esternal reporta-nos ao conceito de hemidiafragma. Sem entrarmos propriamente na apreciação de aspectos embriológicos, que escapam do nosso objetivo e campo de estudo, pode-se distinguir uma antimeria no diafragma considerando-se dois hemidiafragmas segundo sua inserção na coluna vertebral em relação ao plano mediano, ou em relação ao hiato esofágico, e finalmente, uma divisão em hemidiafragmas direito e esquerdo "funcionais" ou "morfo- funcionais" neuromusculares, com fundamento na distribuição dos dois nervos frênicos direito e esquerdo. Esta última, porém, é baseada na inervação motora, que se estabelece no período de desenvolvimento e é considerada fundamental, dada a interrelação ontogenética nervo- músculo.

Consequentemente, o fato de feixes musculares de um lado do esôfago , poderem ser inervados pelo nervo frênico do outro antímero, parece indicar que houve um deslocamento "secundário" de feixes musculares em relação à passagem do trato digestório, durante o desenvolvimento, pelo menos em alguns casos e em algumas espécies e como variação. O mesmo poderia ser aplicado ao cruzamento de nervos na pars sternalis, que seria resultante de deslocamento de feixes musculares, levando sua inervação primitiva. Essa explicação da "gênese formal" desse aspecto poderá ser assim aventada, sendo difícil estabelecer a "gênese causal", nessa como em outras variações em geral.

Assim, aceitando-se a "Hipótese de FÜRBRINGER" apud DALECK (1991) não se poderá admitir uma inervação secundária ou heterotópica, pois a inervação motora primitiva se conserva qualquer que seja a migração do esboço muscular. Portanto, difícil seria receber uma inervação secundária contralateral, ainda que por nervo do antímero homólogo. A hipótese mais aceitável seria a de que a disposição e as inserções da pars lumbalis, como fenômeno secundário, esta- 
belecem-se em função da passagem de estruturas vasculares e órgãos digestórios de uma para outra das cavidades torácica e abdominal, resultando feixes musculares de inserção à direita e à esquerda do plano mediano e que rodeiam o esôfago; mas os respectivos feixes musculares, qualquer que seja seu deslocamento ou situação em relação ao plano mediano, guardariam sempre a sua inervação motora primária homolateral. Restaria responder, quais os fatores por que somente em alguns casos essa disposição ocorre, quer na pars lumbalis quer na pars sternalis, isto é, ressaltamos, qual a sua "gênese causal". Observações em várias espécies, acompanhadas de estudos embriológicos dariam, por certo, condições para ampliar ou completar esse campo de investigação e de discussão tão interessante quanto difícil.

No atinente às conexões ("anastomoses") entre ramos terminais dos nervos frênicos, ou seja, ramos lombar, costal e esternal, não as encontramos em nossas peças, em ovinos da raça Santa Inês, nem homo e/ou heterolaterais, fato inusitado quando comparado com os resultados da grande maioria dos autores por nós consultados. Entretanto, certos autores identificam a presença de uniões homolaterais, isto é, entre filetes do mesmo lado, como é o caso de NEVES (1968) em fetos de bovinos, SILVA et al. (1979) em gambás, MIGLINO (1982) em caprinos, SANTIAGO (1982) em eqüinos da raça Puro Sangue Inglês e TOCANTINS NETO (1985) em búfalos da raça Murrah. Outros, apenas reconhecem a ocorrência de conexões heterolaterais, ou seja, entre ramos contralaterais, a exemplo de FUNAOKA et al. (1930) apud BERTELLI (1933) em coelhos e cães, LUTNICKI (1953) em suínos, GIROLLA (1955) em bovinos e SOUZA et al. $(1984,1987)$ em bovinos da raça Nelore e suínos da raça Landrace. Por outro lado, um terceiro grupo assinala a existência de "anastomoses" homo e heterolaterais, a saber: CONDE $(1957,1959)$ em cães e suínos, SANTIAGO 
(1986) em eqüinos sem raça definida, AMORIM JÚNIOR (1988) em jumentos nordestinos e MIGLINO (1988) em capivaras.

Acreditamos que a presença de filetes nervosos de um ramo destinados a outros segmentos do diafragma do mesmo lado, que não o seu correspondente, com ou sem "anastomoses", é de fato interessante mas poderá ser explicável por desvio ou variação de trajeto na divisão terminal dos nervos frênicos. Parece-nos mais complicada a disposição encontrada por aqueles autores, de passagem de um filete para outro antímero, quer mediante conexão ou não. Isto implica em complexos aspectos morfo-funcionais e já referidos por nós, que somente poderiam ser melhor explicitados por outros métodos de estudo. Nossa pesquisa, como da maioria desses estudiosos, limita-se à observação puramente anatômica. De qualquer forma porém, como é sabido, com ou sem "anastomose", o fato fundamental interessante é a contribuição de um dado ramo diafragmático principal do nervo frênico a segmento que lhe é "estranho", principalmente quando heterolateral. $\mathrm{Na}$ análise pois, de questões funcionais, não deve ser ignorada a eventualidade dessas contribuições.

Ainda, vale informar sobre o comportamento dos nervos frênicos de ovinos da raça Santa Inês, que não há diferença estatisticamente significante, no relativo à distribuição e ramificação dos focados nervos no diafragma dos animais estudados, quando confrontados os sexos, o mesmo sendo assinalado por NEVES (1968) para fetos de bovinos, SILVA et al. (1979) para gambás, SANTIAGO (1982, 1986) para eqüinos da raça Puro Sangue Inglês e sem raça definida e por AMORIM JÚNIOR (1988) para jumentos nordestinos.

Outro aspecto merecedor de comentário é que para cada modalidade de ramificação e distribuição dos nervos frênicos no diafragma de ovinos da raça Santa 
Inês encontramos ora concordância dos nossos achados com aqueles observados para outras espécies de ruminantes, ora não. Portanto, julgamos que esse fato seja sugestivo de que essa variação de disposição ocorra ao acaso, independente de espécie ou raça.

É interessante salientar que na etapa de elaboração do nosso projeto de tese, aventamos a possibilidade de estabelecer a eventual correspondência entre as raízes formadoras dos nervos frênicos direito e esquerdo e seus ramos terminais pelo simples método de dissecção e, não utilizando nenhum outro de cunho experimental, como realizado por muitos autores para tal fim. Entretanto, LOCCHI (1932b) chama-nos a atenção a respeito da composição mais ou menos plexiforme do nervo frênico, em alguns mamíferos. O autor relata que procedeu à dissociação dos nervos frênicos e parafrênicos no homem e em alguns animais, tendo observado que, nos macacos do novo mundo, a dissociação se processa mais facilmente que no homem, acreditando que isso se deva a uma disposição menos plexiforme do tronco do nervo frênico desses animais, o que já havia sido assinalado por outros autores para esses nervos em outros mamíferos. Entretanto, tivemos dificuldade em conseguir essa dissociação, em ovinos da raça Santa Inês, em algumas tentativas que fizemos, muito provavelmente pelo fato dos fascículos do nervo frênico não serem individualizados por envoltórios conjuntivos próprios. Talvez possa haver mudança de topografia de feixes ou filetes nervosos, dificuldade também apontada por DALECK (1991) para cães e confirmada por CARDIN (1932b), que descreve uma "anastomose" plexiforme entre os três cordões ( $5^{\mathrm{a}}, 6^{\underline{a}}$ e $7^{\mathrm{a}}$ raízes cervicais) em correspondência com a porção terminal do tronco frênico em cães. Essa composição um tanto plexiforme, já foi comentada por CAVALIÉ (1898) apud BERTELLI (1933) ao assim se expressar: "de cada lado o nervo frênico dá um pincel de ramos terminais que se "anastomosam" amplamente com os pequenos ramos do simpático". 
No que tange à participação de outros nervos que não os nervos frênicos na inervação do diafragma de ovinos da raça Santa Inês, observamos a participação de nervos intercostais em todas as nossas peças, com pequenas variações entre os espécimes e/ou antímeros.

Os nossos resultados sobre a inervação do diafragma de ovinos da raça Santa Inês diferem daqueles apresentados por alguns tratadistas veterinários como ZIMMERL (1909); GHOSHAL (1975) e EVANS (1993) e também dos dados exarados pelos estudiosos do assunto, a exemplo de BERTELLI (1894, 1895, 1993); ANDREI (1928); FONTES (1934) e CONDE (1957), os quais afirmam que os nervos frênicos são as principais, e provavelmente únicas fontes de inervação para o diafragma em algumas mamíferos.

Embora nossos resultados mostrem similaridade com aqueles descritos por TESTUT (1911) e TESTUT et al. (1959) para o homem, MIA (1973) para zebuínos e MELO et al. (1993) para cães, que descrevem que o diafragma é inervado por fibras derivadas de nervos intercostais, autores como ANDREI (1928); WARNICK et al. (1979); DYCE et al. (1990) e MOORE (1990) citam que apenas fibras sensitivas desses nervos alcançam o diafragma. Por outro lado, na opinião de CAVALIÉ (1898) e FELIX (1922) apud ROSENBLUETH et al. (1961), as fibras que alcançam o diafragma são fibras motoras, que têm origem nos nervos intercostais. Ressaltamos, entretanto, que é difícil considerar para fins de confronto as informações desses autores, no que tange à natureza dessa inervação pelos nervos intercostais, isto é, se motora ou sensitiva, por não ter sido este o objetivo do estudo ora realizado.

Aliás, a existência de uma inervação extrafrênica que justifique as variações encontradas, é bastante controversa. WILSON (1970), por exemplo, após secção 
unilateral do nervo frênico em gatos, aventa a possibilidade de que fibras acessórias juntem-se ao nervo frênico no terço periférico do seu curso. Dos autores que postulam essa possibilidade de inervação extrafrênica do diafragma, certamente, alguns valeram-se dela para tentar explicar a degeneração incompleta do diafragma após frenicotomia unilateral (SCHLAEPFER, 1925; ANDREI, 1928 e BOTHA, 1957). Outros autores basearam-se na concepção clássica da origem embriológica do diafragma, supondo uma inervação motora extrafrênica através dos nervos intercostais (ROSENBLUETH et al. 1961). DE TROYER et al. (1981) discutem a possibilidade da porção muscular do diafragma não surgir como uma lâmina só, mas de feixes musculares individuais, o que, para alguns autores, acontece na filogênese das espécies animais (KEITH, 1904) e no homem (LANGMAN, 1985).

Ainda no atinente à inervação extrafrênica, as observações de ROSENBLUETH et al. (1961) sobre a participação de nervos intercostais nessa inervação, indicam que há um suprimento motor do diafragma que não está diretamente conectado ao centro respiratório. O diafragma não é exclusivamente um músculo respiratório; ele se contrai durante algumas ações não respiratórias: tosse, vômito, defecação, parto e etc. Os resultados sugerem que os nervos intercostais, e especialmente do $7^{\circ}$ ao $9^{\circ}$ são importantes vias eferentes para algumas dessas ações ou reflexos.

Continuando os comentários sobre a inervação extrafrênica, o trabalho de SCHLAEPFER (1931) leva em consideração algumas das possíveis explicações abordadas anteriormente, uma vez que apesar de relatar a completa atrofia homolateral do hemidiafragma, indica também alguma porção do músculo no lado operado intacta ou com variável hipertrofia muscular, possivelmente suprida, segundo ele, por outro nervo. 
Sem levarmos em consideração a natureza dessa inervação extrafrênica, observamos nos espécimes ovinos da raça Santa Inês, mais freqüentemente em 63,33\% das peças, a contribuição de nervos intercostais (do VIII ao XII pares) na inervação do diafragma em ambos os antímeros e em $26,68 \%$ das oportunidades, surpreendemos a participação do IX ao XII pares. A contribuição de nervos intercostais na inervação do diafragma, também foi constatada por MIA (1973) em zebuínos, que comenta que as inserções costais do músculo recebem filamentos dos seus últimos nervos intercostais, citação bastante próxima à nossa e ainda por MELO et al. (1999), que relatam a participação do VII ao XII pares de nervos intercostais na inervação do diafragma de cão, em $93,50 \%$ dos casos. Esses relatos são concordantes com a descrição genérica de BARONE (1993), de que filetes de nervos intercostais mergulham na porção carnosa periférica do diafragma.

Em nossa opinião e de alguns autores referendados, essa contribuição de nervos intercostais encontra uma explicação lógica na origem embriológica do diafragma, a partir de quatro fontes diferenciadas, sendo uma delas, representada pela parede lateral do corpo, fato que provavelmente, poderá desviar filetes de nervos intercostais da parede até o diafragma, justificando, desta forma, a presença desses nervos a distribuirem-se imediatamente, em correspondência à linha de inserção costal do diafragma, em curtos ramos que mergulham na porção periférica da parte carnosa do músculo.

Seguindo esta mesma linha de raciocínio, era de se esperar que, também, a porção lombar do diafragma recebesse a contribuição de filetes nervosos derivados de nervos lombares, já que essa porção do músculo provém do mesoesôfago que se insere na região lombar. Entretanto, curiosamente, não detectamos nenhuma contribuição desses nervos na inervação dos trinta diafragmas estudados, aspecto verificado apenas por MIA (1973) em zebuínos, 
relatando então que os pilares do diafragma são também inervados pelos ramos ventrais do $1^{\circ}$ e $2^{\circ}$ nervos lombares.

Resta saber, portanto, qual a contribuição efetiva desses nervos (intercostais e lombares) nas funções do diafragma, em outras palavras, eles participariam da via principal de inervação respiratória, ou pertenceriam à via eferente reflexa relacionada a outras ações não respiratórias desempenhadas pelo músculo e sugerida pelas pesquisas de ROSENBLUETH et al. (1961). As informações sobre o assunto, ainda, encontram-se bastante desencontradas e, ao nosso ver, não esgotadas. De qualquer forma a revisão do tema merece estudo minucioso para maiores elucidações.

Finalmente, achamos prudente que clínicos, cirurgiões, radiologistas e outros especialistas estejam atentos às possíveis conseqüências, quanto à inervação das diferentes porções do diafragma de ovinos da raça Santa Inês (e também de outras espécies), de afecções que comprometam não apenas diretamente os nervos frênicos e seus ramos terminais mas, também suas raízes espinhais bem como a própria região cervical da medula espinhal, particularmente no relativo aos segmentos $\mathrm{C} 5, \mathrm{C} 6$ e $\mathrm{C} 7$ e especialmente, em relação a C6 , pois conforme concluímos, aparece como principal fornecedor de fibras nervosas para constituição do nervo frênico propriamente dito. Aliás, como bem referem MEREDINO et al. (1956), para as abordagens cirúrgicas do diafragma, é essencial o conhecimento da distribuição dos ramos terminais do nervo frênico, na porção carnosa, para que possam ser preservados evitando-se, assim, complicações pós- operatórias atribuídas a lesões dessas estruturas. 
Por tudo que comentamos, torna-se recomendável estudo sistemático sobre tais aspectos, não apenas em ovinos, mas também em outras espécies animais, para que tenham os estudiosos do assunto condições cada vez maiores de preservar a saúde e o bem-estar da vida animal. 
Conclusões

monctusoes 
Do que acabamos de expor, referente à inervação do diafragma de ovinos da raça Santa Inês, julgamos válidas as conclusões que se seguem:

1- O diafragma de ovinos da raça Santa Inês é inervado pelos nervos frênicos direito e esquerdo (100,00\%) e, ainda, pelos nervos intercostais do VIII ao XII pares $(63,33 \%)$, do IX ao XII pares (26,67\%) e do VIII ao XII pares (3,33\%).

2- Os nervos frênicos originam-se mais freqüentemente a partir dos ramos ventrais do $5^{\circ}(\mathrm{C} 5)$ e $6^{\circ}(\mathrm{C} 6)$ nervos espinhais cervicais tanto à direita $(46,67 \%)$ como à esquerda (43,33\%). C5 contribui sempre com um filete nervoso enquanto $\mathrm{C} 6$ contribui com dois filetes à direita $(13,33 \%)$ e à esquerda $(9,99 \%)$.

3- A origem dos nervos frênicos através dos ramos ventrais do $6^{\circ}$ (C6) e $7^{\circ}(\mathrm{C} 7)$ nervos espinhais cervicais, bem como a partir dos ramos ventrais do $5^{\circ}(\mathrm{C} 5), 6^{\circ}$ (C6) e $7^{\circ}$ (C7) nervos espinhais cervicais, não constitui uma ocorrência rara, nos ovinos da raça Santa Inês, ou seja, respectivamente à direita (23,33\% e 30,00\%) e à esquerda (16,66\% e 33,34\%).

4- A união dos ramos ventrais formadores dos nervos frênicos direito e esquerdo, nos ovinos da raça Santa Inês, ocorre em diferentes níveis após sua origem a partir dos respectivos nervos espinhais cervicais, vale dizer, em correspondência às articulações entre a $5^{\underline{a}}$ e $6^{\underline{a}}$ vértebras cervicais, às articulações entre a $6^{a}$ e $7^{a}$ vértebras cervicais ou ao nível da $1^{1}$ costela e espaço intercostal correspondente, tanto à direita como à esquerda.

5- As abordagens dos nervos frênicos direito e esquerdo, nos ovinos da raça Santa Inês, devem ser realizadas na cavidade torácica e a partir do $1^{\circ}$ par de costelas, evitando deste modo, observações parciais e incorretas, pela análise isolada de filetes formadores dos nervos estudados. 
6- Os nervos frênicos dos ovinos da raça Santa Inês têm origem simétrica, isto é, a partir de um mesmo número de filetes nervosos à direita e à esquerda, em $63,33 \%$ das preparações e origem assimétrica em $36,67 \%$ dos casos.

7- Os nervos frênicos terminam em tronco lombocostal e ramo esternal à direita (40,00\%) e à esquerda (20,00\%); em ramos lombocostal e esternal, à esquerda $(36,68 \%)$ e à direita (33,33\%); em ramo lombar e tronco costoesternal, à esquerda $(23,33 \%)$ e à direita $(6,67 \%)$; em troncos lombocostal e costoesternal, à direita $(16,67 \%)$ e à esquerda (3,33\%); em ramos lombar, costal (em número de dois) e esternal, à esquerda (13,33\%); em ramos lombar e costal e tronco costoesternal, à esquerda ( $3,33 \%)$; em tronco lombocostal e ramos costal e esternal, à direita $(3,33 \%)$.

8- Os nervos frênicos direito e esquerdo comportam-se simetricamente em ramos lombar, costal e esternal (16,67\%); em tronco lombocostal e ramo esternal (10,00\%); em ramo lombar e tronco costoesternal (6,67\%); em troncos lombocostal e costoesternal (3,33\%).

9- Os ramos lombares dos nervos frênicos direito e esquerdo inervam à direita $(46,67 \%)$ e à esquerda $(96,67 \%)$, somente o pilar homolateral do diafragma (pars lumbalis). Nos outros casos, à direita (53,33\%) e à esquerda (3,33\%), distribuem-se também a outras estruturas, ou seja: à direita $(50,00 \%)$, à veia cava caudal; à direita $(3,33 \%)$, à veia cava caudal e ao folíolo dorsal direito simultaneamente; à esquerda (3,33\%), ao folíolo dorsal esquerdo.

10- Os ramos costais dos nervos frênicos direito e esquerdo inervam à esquerda $(90,00 \%)$ somente a pars costalis, mais precisamente, suas regiões dorsal e ventral. Nas preparações restantes, à direita $(23,33 \%)$ e à esquerda $(10,00 \%)$, distribuem-se também a outra estrutura, isto é, ao folíolo ventral. 
11- Os ramos esternais dos nervos frênicos direito e esquerdo inervam à direita $(100,00 \%)$ e à esquerda (83,33\%), somente a pars sternalis e a região ventral da pars costalis do antímero correspondente. Nas outras peças, à esquerda (16,67\%) exibem outros arranjos de distribuição, ou seja: inervam somente a pars sternalis homolateral do diafragma (6,67\%); além da pars sternalis e da região ventral da pars costalis, emitem filete nervoso ao folíolo ventral $(6,67 \%)$ e a uma pequena área circular muscular localizada no folíolo ventral (3,33\%).

12- Não é observada a presença de conexões ("anastomoses") homo e/ou heterolaterais entre os ramos terminais dos nervos frênicos direito e esquerdo.

13- Pela aplicação do Teste de Associação, verifica-se que não há interferência da variável sexo sobre o comportamento dos nervos frênicos no tocante às suas origens e distribuições no diafragma de ovinos da raça Santa Inês, tudo ocorrendo pelo acaso.

14- Os nervos intercostais, do VIII ao XII pares $(63,33 \%)$ e do IX ao XII pares (26,68\%) contribuem na inervação do diafragma, destinando-se à porção mais lateral da pars costalis e dividindo-se imediatamente, em correspondência à linha de inserção costal do diafragma, em curtos ramos que mergulham na porção periférica da parte carnosa. Nas peças restantes, verificamos a participação do VIII ao XIII pares de nervos intercostais $(3,33 \%)$ na inervação do diafragma, assim como, a ausência do XII nervo intercostal, à esquerda (3,33\%) e do IX nervo intercostal, à direita (3,33\%).

15- Não verificamos contribuição de nervos lombares na inervação do diafragma de ovinos da raça Santa Inês. 


\section{Referências*}

* Conforme as diretrizes para apresentação de Dissertações e Teses. 3. ed. São Paulo: FMVZ-USP, 2001. 56 p. 
AMORIM JÚNIOR, A. A. Ramificação e distribuição dos nervos frênicos no diafragma de jumentos nordestinos. 1988. 63 f. Dissertação (Mestrado em Anatomia dos Animais Domésticos) - Faculdade de Medicina Veterinária e Zootecnia, Universidade de São Paulo, São Paulo.

AMORIM JÚNIOR, A. A .; BITTENCOURT, A .M.; AMORIM, M. J. A. L. Ramificação e distribuição dos nervos frênicos no diafragma em sagui (Callithrix jacchus). In :CONGRESSO BRASILEIRO DE ANATOMIA, 16. , 1993, São Paulo. Anais... São Paulo: Sociedade Brasileira de Anatomia, 1993. Resumo 68.

ANDREI, O. Sulle alterazioni anatomiche del diaframma che susseguono ad eseresi del nervo frênico. Archivio Italiano di Chirurgia, v. 21, n. 4, p. $313-$ 328, 1928.

AREY, L. B. Mesenterios y celoma. In : Anatomia del desarrolo : tratado y manual de laboratório. Buenos Aires: Vasquez, 1964. p. 231-232.

BAMEL, S. S.; DHINGRA, L. D.; SINGH, Y. The pherenic nerve of the buffalo (Bos bubalis). Philippine Journal of Veterinary Medicine, v. 10, p. 36-41, 1970.

BARONE, R. Muscle du thorax. In: Anatomie comparée des mammiferes domestiques: arthrologie et myologie. Paris: Vigot, 1989. v. 2, p. 641.

BERTELLI, D. 1894 apudCONDE, R. 1957, p. 6.

BERTELLI, D. Ricerche sulla morfologia del muscolo diaframma nei mammiferi. Archivio per le Scienze Mediche, v. 19, n. 4, p. 381-436,1895.

BERTELLI, D. 1895 apud LOCCHI, R.1931, p.16.

BERTELLI, D. Distribuzione dei nervi frenice nei diaframma dei mammíferi. Archivio Italiano di Anatomia e di Embriologia, v. 32, n. 1, p. 110 - 148, 1933.

BOTHA, G. S. M. The anatomy of phrenic nerve termination and the motor innervation of the diaphragm. Thorax, v. 12, p. 50-56, 1957. 
CARDIN, A. Distribuzione radicolare dei nervi frenici nel diaframma. I. Bolletino della Societá Italiana di Biologia Sperimentali, v. 9, p. 102-104, 1936 a.

CARDIN, A . Distribuzione radicolare dei nervi frenici nel diaframma. II. Bolletino dela Societá Italiana di Biologia Sperimentale, v. 9, p. 104-106, 1936 b.

CARDIN, A.; FRANCESCON, M. Distribuzione radicolare dei nervi freneci nel diaframa: ricerchi isto - funzionali . III . Bolletino della Societá Italiana di Biologia Sperimentale, v. 12, p. 155-156, 1937.

CARVALHO, M. A . M.; CARVALHAL, R.; MIGLINO, M. A.; SILVINO, M. J. Ramificação e distribuição dos nervos frênicos do diafragma de cutia (Dasyprocta aguti, Rodentia). In: CONGRESSO BRASILEIRO DE ANATOMIA, 16., 1993, São Paulo. Anais... São Paulo: Sociedade Brasileira de Anatomia, 1993. Resumo 69.

CAVALIÉ , C. 1898 apud BERTELLI , D. 1933, p. 111.

CAVALIÉ , C. 1898 apud ROSENBLUETH, A.; ALANÍS, J.; PILAR, G. 1961, p.19.

CHAUVEAU, A.; ARLOING, S.; LESBRE, F. X. Appareil de l'innervation. In:_. Traité d'anatomie comparée des animaux domestiques. 5. ed. Paris: J. B. Bailliére, 1905a. v. 2, p. 407-409.

CHAUVEAU, A.; ARLOING, S.; LESBRE, F. X. Appareil de l'innervation. In:_ Traité d'anatomie comparée des animaux domestiques. 5. ed. Paris: J. B. Bailliére, 1905b. v. 2, p. 552-553.

CONDE , R. Estudo anatômico sobre a distribuição dos nervos frênicos no músculo diafragma de Canis familiaris. Arquivos da Escola Superior de Veterinária da Universidade Rural do Estado de Minas Gerais, Belo Horizonte, v. 10, p. 329-365, 1957.

CONDE, R. Estudo anatômico com dados experimentais sobre a distribuição dos nervos frênicos no músculo diafragma de Sus scrofa domesticus. 1959. 84 f. Tese (Cátedra em Anatomia dos Animais Domésticos) - Escola Superior de Veterinária, Universidade Rural do Estado de Minas Gerais, Belo Horizonte. 
DALECK, C. L. M. Estudo anatômico da correspondência entre raízes medulares do nervo frênico e seus ramos terminais em Canis familiaris. 1991. $79 \mathrm{f}$. Tese (Doutorado em Anatomia dos Animais Domésticos) - Faculdade de Medicina Veterinária e Zootecnia, Universidade de São Paulo, São Paulo.

DE TROYER, A.; SAMPSON, M.; SIGRIST, S.; MACKLEM, P. T. The diaphragm : two muscles. Science, v. 213, p. 237-238, 1981.

DIAS, S. M.; ORSI, A. M.; CAMPOS, V. J. M.; TAMEGA, O. J. Estudo da origem do nervo frênico no Canis familiaris. Revista de Medicina Veterinária, São Paulo, v. 9, n. 3, p. 240-245, 1974.

DOBBERSTEIN, J.; HOFFMAN, G. Nervensystem. In: . Lehrbuch der vergleichenden anatomie der haustiere. Leipzig: S. Hirzel,1964. v. 3. p. 165.

DYCE, K. M.; SACK, W. O.; WENSING, C. J. G. O sistema nervoso. In: Tratado de anatomia veterinária. Rio de Janeiro: Guanabara Koogan, 1990. p. 217.

ELLENBERGER, W.; BAUM, H. Nervensystem. In: Handbuch der vergleichenden anatomie der haustiere. Berlim: Verlag J. Springer, 1932. p. 894-895.

EVANS, H. E. The spinal nerves. In: Miller 's anatomy of the dog. 3. ed. Philadelphia: W. B. Saunders, 1993. p. 840-841.

FÉLIX, A. 1922 apud ANDREI, O. 1928, p. 326.

FÉLIX, A. 1922 apud ROSENBLUETH, A .; ALANÍS, J.; PILAR G. 1961, p. 19. FERREIRA, N.; D'ERRICO, A. A.; PRADA, I. L. S.; SOGORB, S. F. Distribuição dos nervos frênicos no diafragma do ratão do banhado (Miocastor coypus). In: CONGRESSO BRASILEIRO DE ANATOMIA, 13., 1981, Belo Horizonte. Anais... Belo Horizonte: Sociedade Brasileira de Anatomia, 1981. p. 102.

FERREIRA, N.; FERNANDES FILHO, A.; D'ERRICO, A. Distribuição dos nervos frênicos no diafragma em carneiros da raça Corriedale. In: JORNADA CIENTÍFI- 
CA DA FACULDADE DE CIÊNCIAS MÉDICAS E BIOLÓGICAS DE BOTUCATU, 3., 1973, Botucatu. Anais... Botucatu: Faculdade de Ciências Médicas e Biológicas, 1973. p. 263.

FONTES, V. Notes anatomo - physiologiques sur l'etude du muscle diaphragme. Arquivo de Anatomia e Antropologia, v. 7, p.33-46, 1934.

FUNAOKA, S.; MORITA, G. 1930 apudBERTELLI, D. 1933, p.113-114.

GHOSHAL, N.G. Nervos espinhais. In: GETTY, R. Anatomia dos animais domésticos. 5. ed. Rio de Janeiro: Guanabara Koogan, 1975. v. 1, p. 1052-1055.

GIROLLA, W. Der nervus phrenicus des rindes: seine morphologie, topik, innervations und funktionsaufgaben. 1955. $44 \mathrm{f}$. Tese (Doutorado em Medicina Veterinária) - Institute der Tierarztlichen Hochschule, Viena.

GONZÁLEZ Y GARCIA, J.; GONZÁLEZ ALVAREZ, R. Sistema muscular. In: Anatomia comparada de los animales domesticos. 3. ed. Saragoza: La Académica, 1929. p. 341-344.

GONZÁLEZ Y GARCIA, J.; GONZÁLEZ ALVAREZ, R. Sistema muscular. In: Anatomia comparada de los animales domesticos. 6. ed. Madrid: Juan Puevo, 1949. p. 319.

GRAY, S. W. ; SKANDALAKIS, J. E. 1972 apud AMORIM JÚNIOR, A. A. 1988, p. 43.

INTERNATIONAL COMMITEE ON VETERINARY GROSS ANATOMICAL NOMENCLATURE. Nomina anatomica veterinaria. 4. ed. Zurich, 1994.

JANSEN , J. 1931 apud MIGLINO, M. A. 1982, p. 2.

JEFFERSON, N. C.; CLYDE, W. P.; NECHELES, H. Observations on diaphragm and stomach of the dog following phrenicotomy. Proceedings of the Society for Experimental Biology and Medicine, v. 72, p. 482-485, 1949.

KEITH, A. 1904 apud DE TROYER, A. ; SAMPSON, M.; SIGRIST, S.; MACKLEM, P. T. 1981, p. 238. 
LANGMAN, J. 1985 apud DE TROYER, A.; SAMPSON, M.; SIGRIST, S.; MACKLEM, P. T. 1981, p. 238.

LAUNAY, C. 1934 apudFONTES, V. 1934, p.37.

LEITE, E. R. Ovinocaprinocultura no Nordeste: organização e crescimento. A Tarde, Salvador, 24 abr. 2000. Rural, p. 6.

LESBRE, F. X. Appareil de l'innervation. In: Précis d'anatomie comparée des animaux domestiques. Paris: J.B. Bailliére, 1923. v. 2, p. 668669.

LIMA, H. D. F. Produção ovina no Brasil: situação e perspectivas. Revista Brasileira de Reprodução Animal, v. 23, n. 3, p. 145, 1999.

LOCCHI, R. Observações sobre o musculus diaphragma no Bradypus tridactylus. Annaes da Faculdade de Medicina de São Paulo, v. 6 , p. 3-22, 1931.

LOCCHI, R. Sobre a anatomia dos nervos phrenicos e paraphrenicos. Annaes da Faculdade de Medicina de São Paulo, v. 8, p. 3-36, 1932a.

LOCCHI, R. Quelques observations sur le nerve "paraphrénique" (de C5). Folia Clinica et Biologica, v. 4, n. 3, 1932 b.

LOCCHI, R. 1932c apud DALLECK, C. L. M. 1991, p. 3.

LONGO BULL, M. O.; OLIVEIRA DAYOUB, M. C.; ROCHA, G. T. Sobre a inervação dos pilares diafragmáticos pelos nervos frênicos no coelho. In : CONGRESSO BRASILEIRO DE ANATOMIA, 13., 1981, Belo Horizonte. Anais... Belo Horizonte: Sociedade Brasileira de Anatomia, 1981. p. 98.

LUTNICKI, W. The phrenic nerve in the sheep. Annales Universitatis Mariae Curie Sklodowska, Lublin, v. 5, n. 4, p. 47-69, 1950.

LUTNICKI, W. The distribuition of phrenic nerves in the diaphagm in the pig. Annales Universitatis Mariae Curie Sklodowska, Lublin, v. 8, n. 14, p. 282284, 1953. 
MACHADO, T. M. M. Comportamento reprodutivo de ovinos deslanados município de Uberlândia, Minas Gerais. Revista Brasileira de Reprodução Animal, v. 23, n. 3, p. 190, 1999.

MELO, A. P. F.; SOUZA, W. M.; MIGLINO, M. A. A participação dos nervos intercostais na inervação do diafragma em cães. Brazilian Journal of Morphological Sciences, v. 16, n. 1, p. 61-63, 1999.

MENDONÇA, A . C.; CONDE, R.; SOUZA, P. R.; BRITO, O . A.; MORAIS, J. O. Distribuição dos nervos frênicos no músculo diafragma de Calomys calosus. In: CONGRESSO BRASILEIRO DE ANATOMIA, 16., 1993. São Paulo. Anais... São Paulo: Sociedade Brasileira de Anatomia, 1993. Resumo 66.

MEREDINO, K. A.; JOHNSON, R, J.; SKINNER, H. H.; MAGUIRE, R. X. The intradiaphragmatic distribution of the phrenic nerve with particular reference to the placement of diaphragmatic incisions and controlled segmental paralysis. Surgery, v. 39, p. 189-198, 1956.

MIA, A. The innervation of the diaphragm in zebu cattle (Bos indicus). Bangladesh Veterinary Journal, v. 1, n. 1-4, p. 29-32, 1973.

MIGLINO, M. A. Divisão e distribuição dos nervos frênicos no músculo diafragma em Caprinos (Capra hircus - Linnaeus, 1758). 1982. 40f. Dissertação (Mestrado em Anatomia dos Animais Domésticos) - Faculdade de Medicina Veterinária e Zootecnia, Universidade de São Paulo, São Paulo.

MIGLINO, M. A.; PRADA, I. L. S.; SOUZA, W. M. Ramificação e distribuição dos nervos frênicos direito e esquerdo no diafragma em búfalos da raça Jaffarabadi. Revista da Faculdade de Medicina Veteinária e Zootecnia da Universidade de São Paulo, v. 22, p. 97 - 106, 1985.

MIGLINO, M. A.; SOUZA, W. M.; CARVALHAL, R. Distribuição dos nervos frênicos no diafragma de cateto ( Tayassu tayassu ). In: CONGRESSO BRASILEIRO DE ANATOMIA, 16., 1993, São Paulo. Anais... Sociedade Brasileira de Anatomia, 1993. Resumo 67. 
MIGLINO, M. A.; SOUZA, W. M.; CARVALHAL, R.; DiDio, L. J. A. Morfologia e inervação do diafragma de veados (Manzana americana, Manzana simplicicornis e Blastoceros bezoarticus). Brazilian Journal Veterinary Research Animal Science, v. 30, p. 195-203, 1993. Suplemento.

MIGLINO, M. A .; SOUZA, W. M.; DiDio, L. J. A. Distribution of the phrenic nerves in the diaphragm of capybara ( Hydrochoerus hydrocoeris). Archivio Italiano di Anatomia e di Embriologia, v. 93, n.1-2, p. 109-118, 1988.

MIGLINO , M. A.; SOUZA, W. M.; PEREIRA, J. G. L.; CARVALHAL, R. Ramificação e distribuição dos nervos frênicos no diafragma de ovinos da raça Ideal. In: CONGRESSO BRASILEIRO DE ANATOMIA, 14. , 1985, Vitória. Anais... Vitória: Sociedade Brasileira de Anatomia, 1985, p. 109.

MIGLINO , M. A.; SOUZA, W. M.; PRADA, I. L. S.; ARANTES, I. G.; NASCIMENTO, A. A. Ramificação e distribuição dos nervos frênicos no diafragma do tamanduá bandeira ( Myrmicophaga tridactila ). In: CONGRESSO BRASILEIRO DE MEDICINA VETERINÁRIA, 20.,1986. Cuiabá. Anais... Cuiabá: Sociedade Brasileira de Medicina Veterinária, 1986. p. 345.

MOORE, K. L. O abdome. In: Anatomia orientada para a clínica. 2. ed. Rio de Janeiro: Guanabara Koogan, 1990. p. 190-192.

NEVES, I. P. Estudo anatômico da distribuição dos nervos frênicos no músculo diafragma de bovinos ( fetos ). Veterinária, v. 21, p. 29-45, 1968.

NICKEL, R.; SCHUMMER, A. ; SEIFERLE, E. Muskeln des stammes. In:

Lehrbuch der anatomie der haustiere. Berlin: Verlag Paul Parey, 1977. v. 1, p. 322-324.

OLIVEIRA, A.; CONDE, R. Sôbre um caso de feixe muscular cruzando o folíolo dorsal esquerdo do centrum tendíneum do diafragma de cão. Arquivos da Escola Superior de Veterinária, v. 9, p. 127-128, 1956. Nota preliminar.

OLIVEIRA DAYOUB, M. C.; LONGO BULL, M. O.; GUSHIKEN, T. Estudo anatômico sobre o nervo frênico do coelho. In: CONGRESSO BRASILEIRO DE ANATOMIA, 13. , 1981, Belo Horizonte. Anais... Belo Horizonte: Sociedade Brasileira de Anatomia, 1981. p. 101. 
OLIVEIRA, J. J. Apalpe o úbere da Santa Inês. A Tarde, Salvador, 24 abr. 2000. Rural, p. 12.

PANCRAZI, G. Sulla distribuzione del nervo frenice nel diaframma dei mammiferi. Atti del Reale Istituto Veneto de Scienze, Letter ed Arti, v. 85, p. 345 347, 1925. Nota preventiva.

PANCRAZI, G. 1925 apud LOCCHI, R. 1931, p. 16.

PANSINI, S. 1898 apud BERTELLI, D. 1933, p. 110.

PRADA, I.L.S.; AMORIM Jr, A . A.; MIGLINO, M. A.; SOUZA, W. M. Ramificação e distribuição dos nervos frênicos no diafragma em ovinos deslanados. Comunicações Científicas da Faculdade de Medicina Veterinária e Zootecnia da Universidade de São Paulo, v. 11, n. 2, p. 145-146, 1987.

REIGHARD, J.; JENNINGS, H. S. 1957 apud SANT'AMBROGIO, G.; FRASIER, D. T.; WILSON, M. F.; AGOSTONI, E. 1963, p. 44.

RILEY, D. A.; BERGER, J. 1979 apudDE TROYER, A.; SAMPSON, M.; SIGRIST, S.; MACKLEM, P. T. 1981, p.238.

ROMER, A . S.; PARSONS, T. S. Cavidades do corpo. In: Anatomia comparada dos vertebrados . São Paulo: Atheneu, 1985. p. 256- 262.

ROSENBLUETH, A.; ALANÍS, J.; PILAR, G. The accessory motor innervation of the diaphragm. Archives Internationales de Physiologie et de Biochimie, $v$. 69, n. 1, p. 19-25, 1961.

SALGADO, M. C. B.; ORSI, A. M.; VICENTINI, C. A.; DIAS, S. M.; DAYOUB, M. C. O. Estudo do nervo frênico na cobaia (Cavia porcellus, L., 1756): origem e distribuição. In: ENCONTRO DE PESQUISAS VETERINÁRIAS, 6., Jaboticabal, 1981. Anais... Jaboticabal: Faculdade de Ciências Agrárias e Veterinárias de Jaboticabal - UNESP, 1981. p. 43.

SANT'AMBROGIO, G.; FRAZIER, D. T.; WILSON, M. F.; AGOSTONI, E. Motor innervation and pattern of activity of cat diaphragm. Journal of Applied Physiology, v. 18, p. 43-46, 1963. 
SANT'AMBROGIO, G.; FRAZIER, D. T.; WILSON, M. F.; AGOSTONI, E. 1963 apudDE TROYER, A.; SAMPSON, M.; SIGRIST, S.; MACKLEM, P. T. 1981, p.238.

SANTIAGO, W. Contribuição ao estudo da inervação do diafragma em equinos da raça Puro Sangue Inglês. 1982. 19 f. Dissertação (Mestrado em Anatomia dos Animais Domésticos) - Faculdade de Medicina Veterinária e Zootecnia, Universidade de São Paulo, São Paulo.

SANTIAGO, W. Ramificação e distribuição dos nervos frênicos em diafragmas de equinos sem raça definida. 1986. $87 \mathrm{f}$. Tese (Doutorado em Anatomia dos Animais Domésticos) - Faculdade de Medicina Veterinária e Zootecnia, Universidade de São Paulo, São Paulo.

SCHLAEPFER, K. A further note on the motor innervation of the diaphragm. Anatomical Record , v. 31, n. 4, p. $143-150,1925$.

SCHLAEPFER, K. Weiterer beitrag zur frage der motorischen innervation des zwerchfelles. Archive fur Klinische Chirurgie, v. 164, p. 233-239, 1931.

SCHWARZE, E.; SCHRÖDER, L. Nervios cervicales. In: Compendio de anatomia veterinária. Zaragoza: Acribia, 1972. v. 4, p. 63-66.

SILVA, L. E. B.; FERREIRA, N.; FERNANDES FILHO, A. Contribuição ao estudo dos nervos frênicos em Didelphis aurita : I. sistematização dos ramos terminais. II. distribuição dos ramos terminais. Revista da Faculdade de Medicina Veterinária e Zootecnia da Universidade de São Paulo, v. 16, n. 1-2, p. 3740, 1979.

SOUZA, W. M.; MIGLINO, M. A.; MACHADO, C. R.; CARVALHAL, R. Considerações sobre os níveis de origem dos nervos frênicos em bovinos azebuados. Arquivos de Biologia e Tecnologia, v. 28, p. 619-624, 1985.

SOUZA, W. M.; MIGLINO, M. A.; PRADA, I. L. S.; SOUZA, N. T. M. Sobre a ramificação e distribuição dos nervos frênicos direito e esquerdo no diafragma, em suínos, (Sus scrofa domesticus, L. 1758 ) da raça Landrace. Ars Veterinária, v. 3, n. 2, p. $171-178,1987$. 
SOUZA, W. M.; PEREIRA, J. G. L.; ALBUQUERQUE, J. F. G. Contribution to the study of diaphragm innervation in Nelore bovines. Anatomischer Anzeiger, v. 155, p. $317-323,1984$.

TAMEGA, O. J.; MELLO DIAS, S.; ORSI, A. M.; CAMPOS, V. J. M. Origem do nervo frênico no gato ( Felis domestica ). Arquivos da Escola de Veterinária da Universidade Federal de Minas Gerais, v. 27, n. 2 , p. 205-208, 1975.

TESTUT, L. Diaphragme. In: Traité d'anatomie humaine. Paris: Octave Doin et Fils, 1911. v. 1, p. 896-897.

TESTUT, L.; LATARJET, A. Región superior ou diafragmática. In: Tratado de anatomia humana. Barcelona: Salvat, 1959, v. 1, p. 994.

TOCANTINS NETO, A. A. Divisão e distribuição dos nervos frênicos no diafragma de búfalos (Bubalus bubalis - Linnaeus, 1758) da raça Murrah. 1985. 74 f. Dissertação (Mestrado em Anatomia dos Animais Domésticos) - Faculdade de Medicina Veterinária e Zootecnia, Universidade de São Paulo, São Paulo.

URBANOWICZ, Z.; ZALUSKA, S. Various patterns of branching and connections of the phrenic nerve in man and in macacus. Annales Universitates Mariae Curie - Sklodowska, Lublin, v. 21, n. 3, p. 23-39, 1966.

WARWICK, R.; WILLIAM, P. L. Neurologia In: GRAY, H. Gray anatomia. 35. ed. Rio de Janeiro: Guanabara Koogan, 1979. v. 1, p. 984.

WARWICK, R.; WILLIAM, P. L. Neurologia In: GRAY, H. Gray anatomia. Rio de Janeiro: Guanabara Koogan, 1995. v. 1, p. 975.

WILSON, A. S. Experimental studies on the innervation of the diaphragm in cats. Anatomical Record , v. 168, p. $537-541,1970$.

ZIMMERL, U. Sistema nervoso. In: BOSSI, V.; CARADONNA, G. B.; SPAMPANI, G.; VARALDI, L.; ZIMMERL, U. Trattato di anatomia veterinaria. Milano: Francesco Vallardi, 1909. v. 3, p. 228-229

ZIMMERL, U. Apparecchio nervoso. In: BRUNI, A. C.; CARADONNA, G. B.; MANNU, A.; PREZIUSO, L; ZIMMERL, U. Trattato di anatomia veterinaria. Milano: Francesco Vallardi, 1930. v. 3, p. 476. 
Ilustrações 


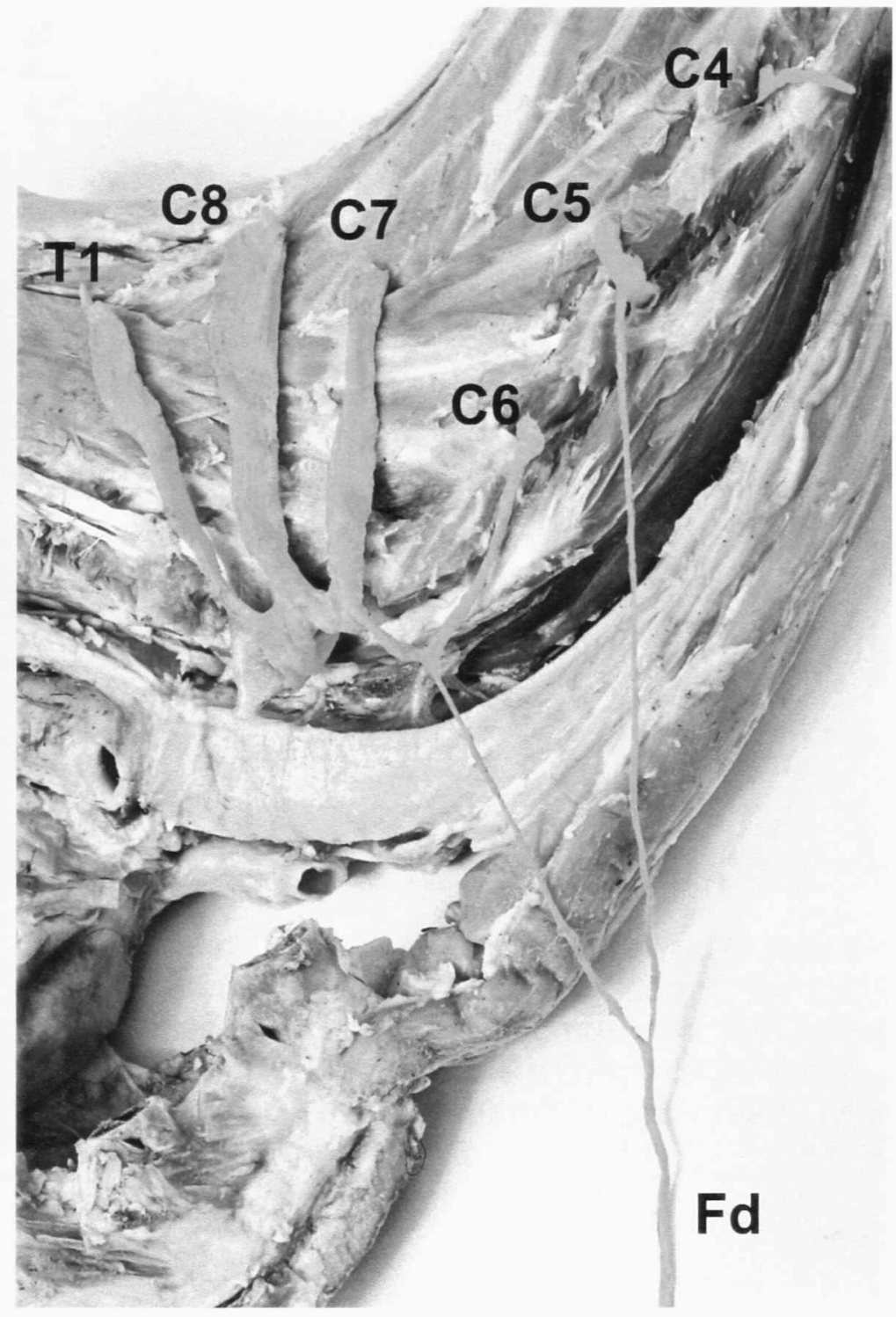

FIGURA 2 -Terço distal da região cervical (vista lateral direita) de ovino da raça Santa Inês (Obs. 13M). O nervo frênico direito ( $\mathbf{F d})$ origina-se de duas raízes procedentes dos ramos ventrais do $5^{\circ}$ (C5) e $6^{\circ}$ (C6) nervos espinhais cervicais. $\mathbf{C 5}$ e $\mathbf{C 6}$ contribuem com um único filete nervoso. C4 - $4^{\circ}$ nervo espinhal cervical; C7 - $7^{\circ}$ nervo espinhal cervical; $\mathbf{C 8}-8^{\circ}$ nervo espinhal cervical; T1 $-1^{\circ}$ nervo espinhal torácico. 


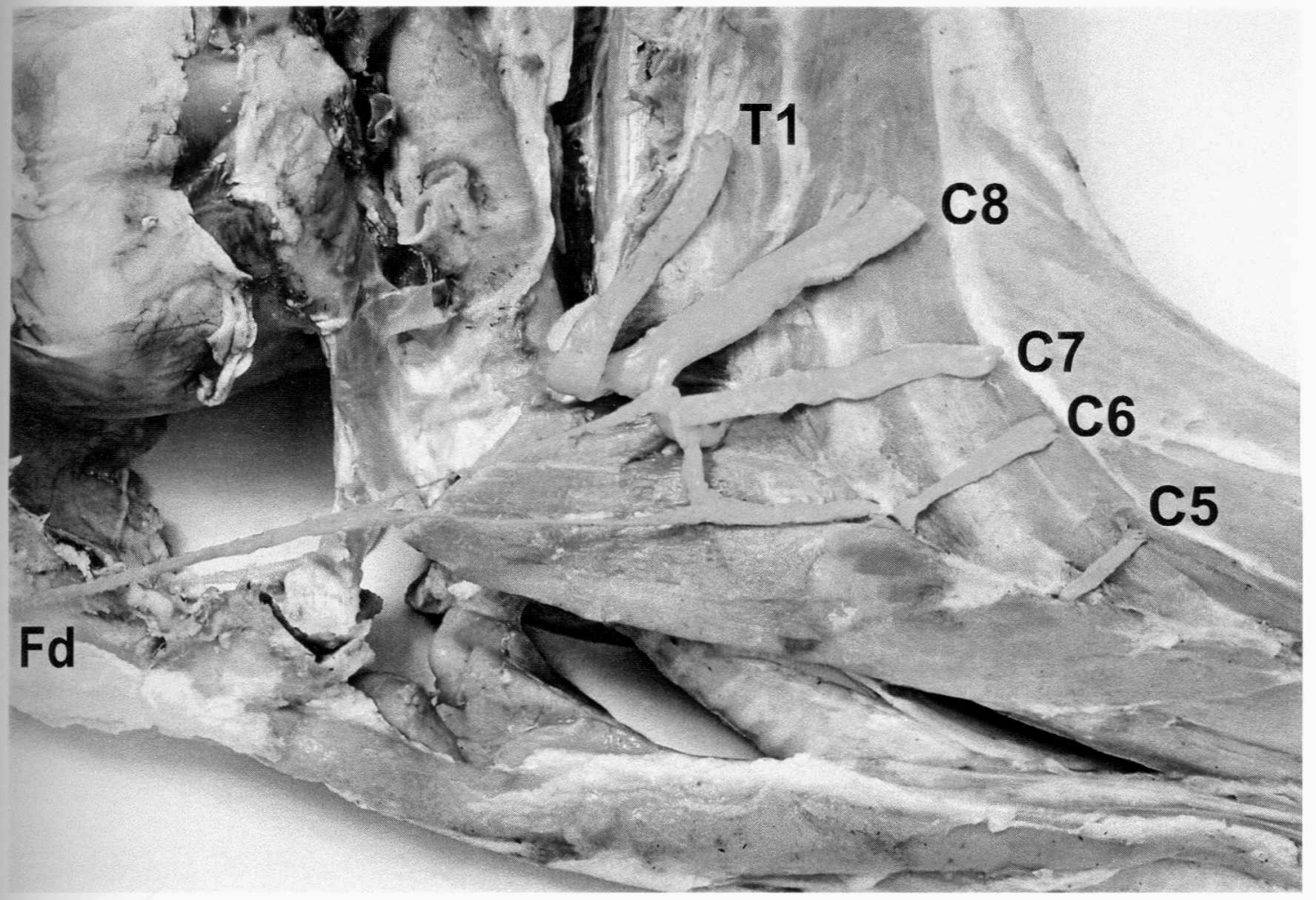

FIGURA 3 -Terço distal da região cervical (vista lateral direita) de ovino da raça Santa Inês (Obs. 21F). O nervo frênico direito (Fd) origina-se de duas raízes procedentes dos ramos ventrais do $6^{\circ}(\mathbf{C} 6)$ e $7^{\circ}(\mathbf{C} 7)$ nervos espinhais cervicais. $\mathbf{C} 6$ e $\mathbf{C 7}$ contribuem com um único filete nervoso. C5 - $5^{\circ}$ nervo espinhal cervical; C8 - $8^{\circ}$ nervo espinhal cervical; T1 - $1^{\circ}$ nervo espinhal torácico. 


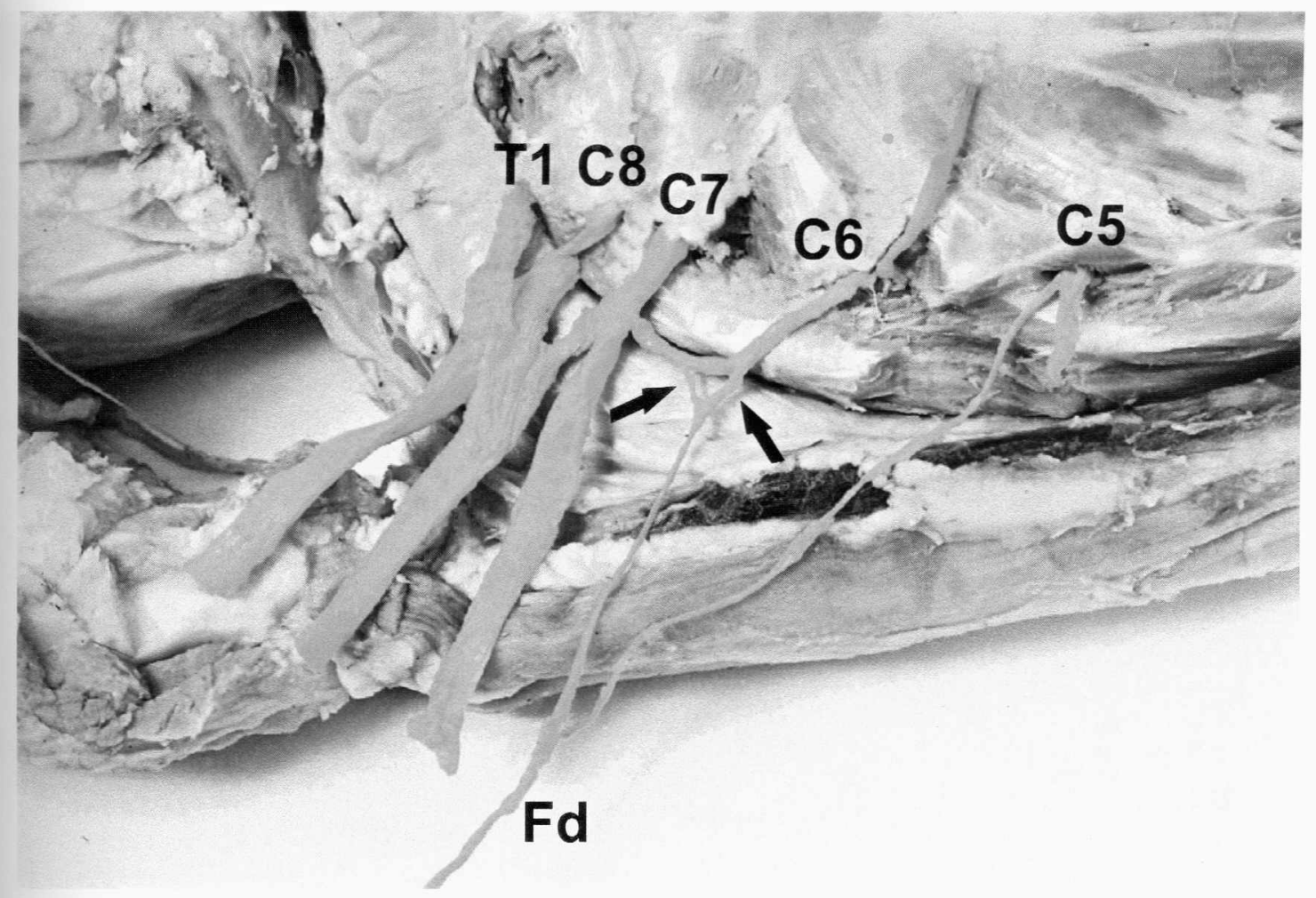

FIGURA 4 - Terço distal da região cervical (vista lateral direita) de ovino da raça Santa Inês (Obs. 12M). O nervo frênico direito (Fd) origina-se de duas raízes procedentes dos ramos ventrais do $5^{\circ}(\mathbf{C 5})$ e $6^{\circ}(\mathbf{C 6})$ nervos espinhais cervicais. C5 contribui com um único filete nervoso e $\mathbf{C 6}$ com dois filetes (setas). $\mathbf{C 7}-7^{\circ}$ nervo espinhal cervical; $\mathbf{C 8}-8^{\circ}$ nervo espinhal cervical; T1 - $1^{\circ}$ nervo espinhal torácico. 


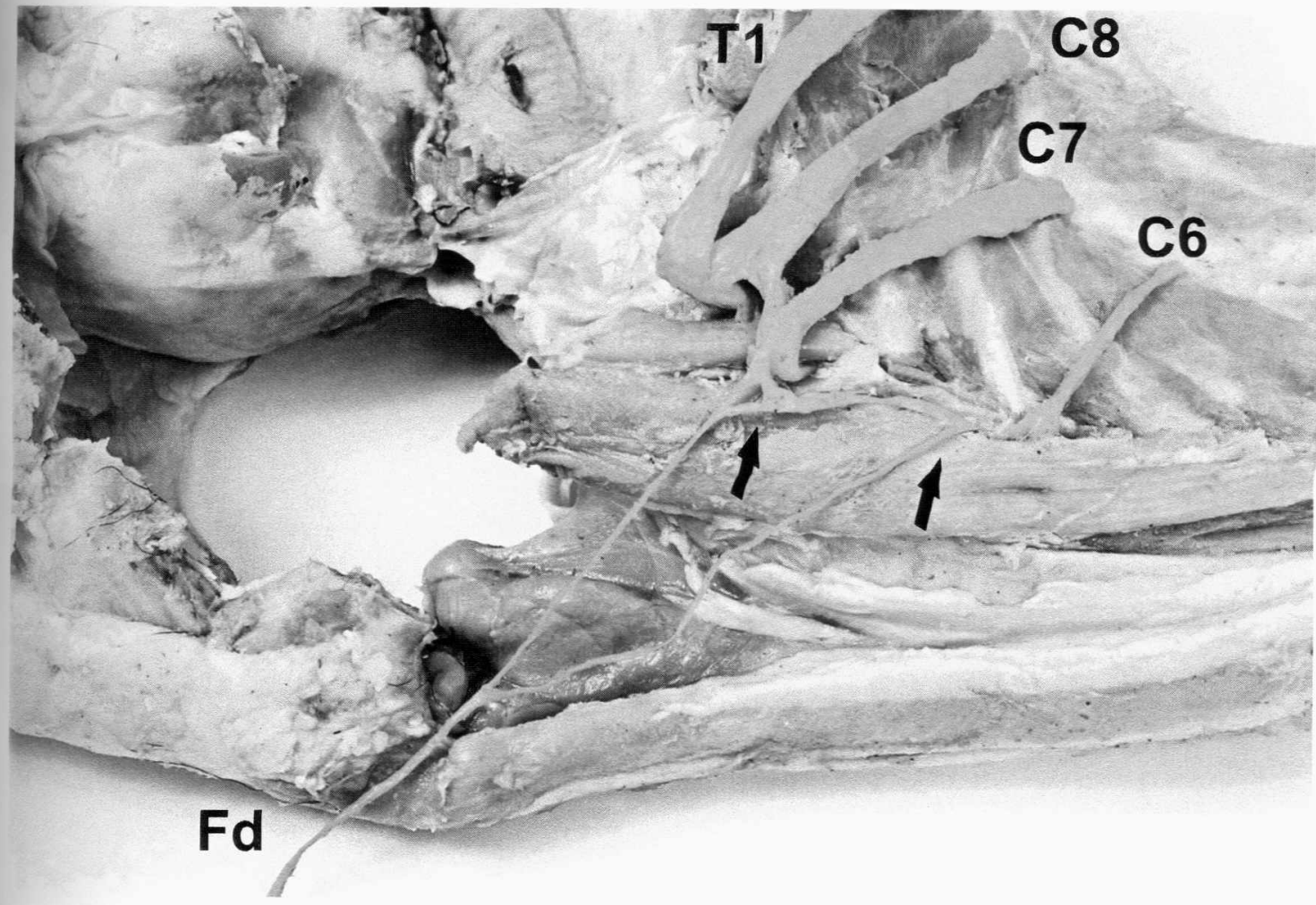

FIGURA 5 -Terço distal da região cervical (vista lateral direita) de ovino da raça Santa Inês (Obs. 15F). O nervo frênico direito (Fd) origina-se de duas raízes procedentes dos ramos ventrais do $6^{\circ}(\mathbf{C 6})$ e $7^{\circ}(\mathbf{C} 7)$ nervos espinhais cervicais. $\mathbf{C} 7$ contribui com um único filete nervoso e $\mathbf{C 6}$ com dois filetes (setas). $\mathbf{C} 8$ - $8^{\circ}$ nervo espinhal cervical; T1 - $1^{\circ}$ nervo espinhal torácico. 


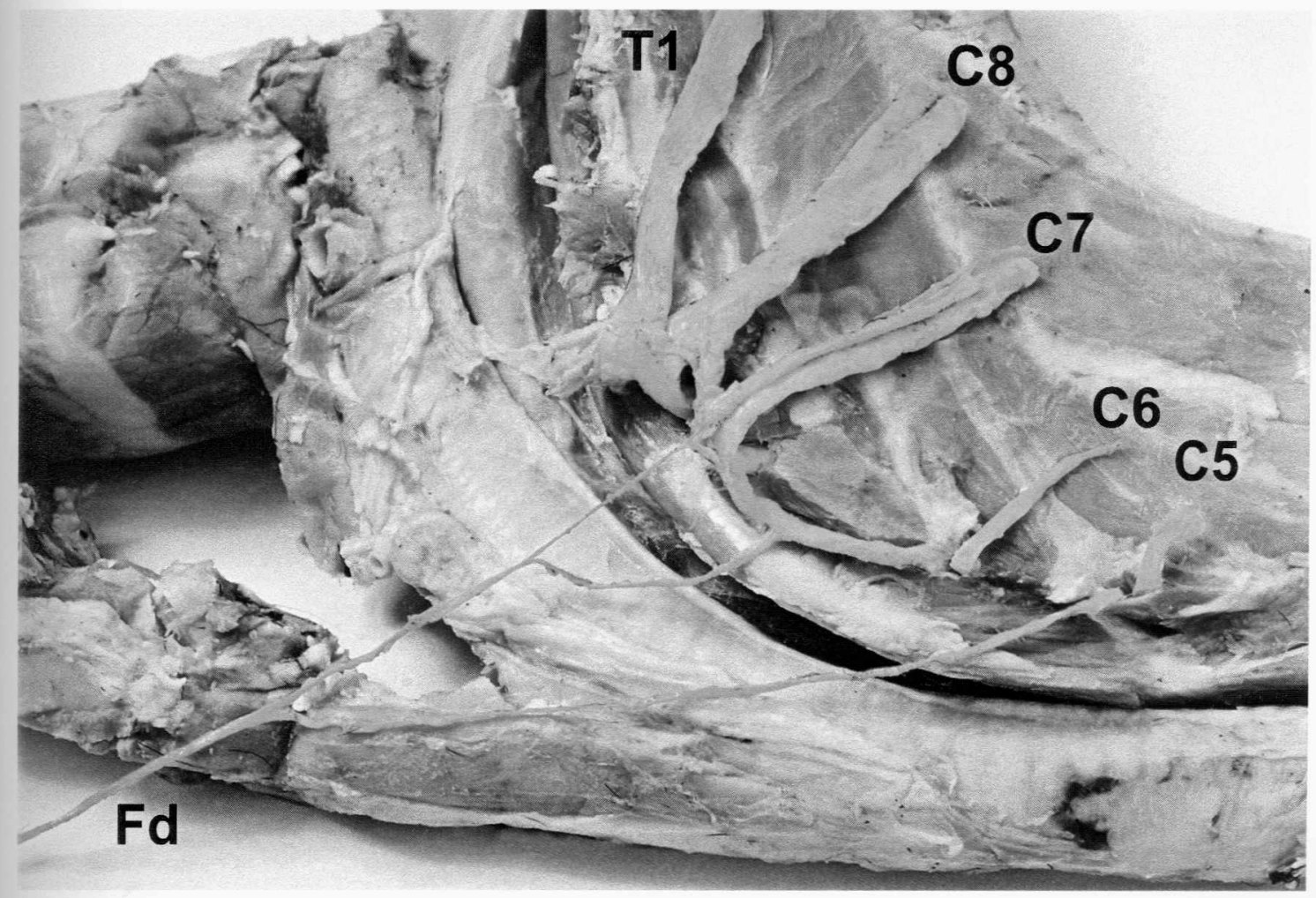

FIGURA 6 -Terço distal da região cervical (vista lateral direita) de ovino da raça Santa Inês (Obs. 9M). O nervo frênico direito $(\mathbf{F d})$ origina-se de três raizes procedentes dos ramos ventrais do $5^{\circ}(\mathbf{C 5}), 6^{\circ}(\mathbf{C 6})$ e $7^{\circ}(\mathbf{C 7})$ nervos espinhais cervicais. $\mathbf{C 5}, \mathbf{C} 6$ e $\mathbf{C 7}$ contribuem com um único filete nervoso; $\mathbf{C 8}-8^{\circ}$ nervo espinhal cervical; T1 - $1^{\circ}$ nervo espinhal torácico. 


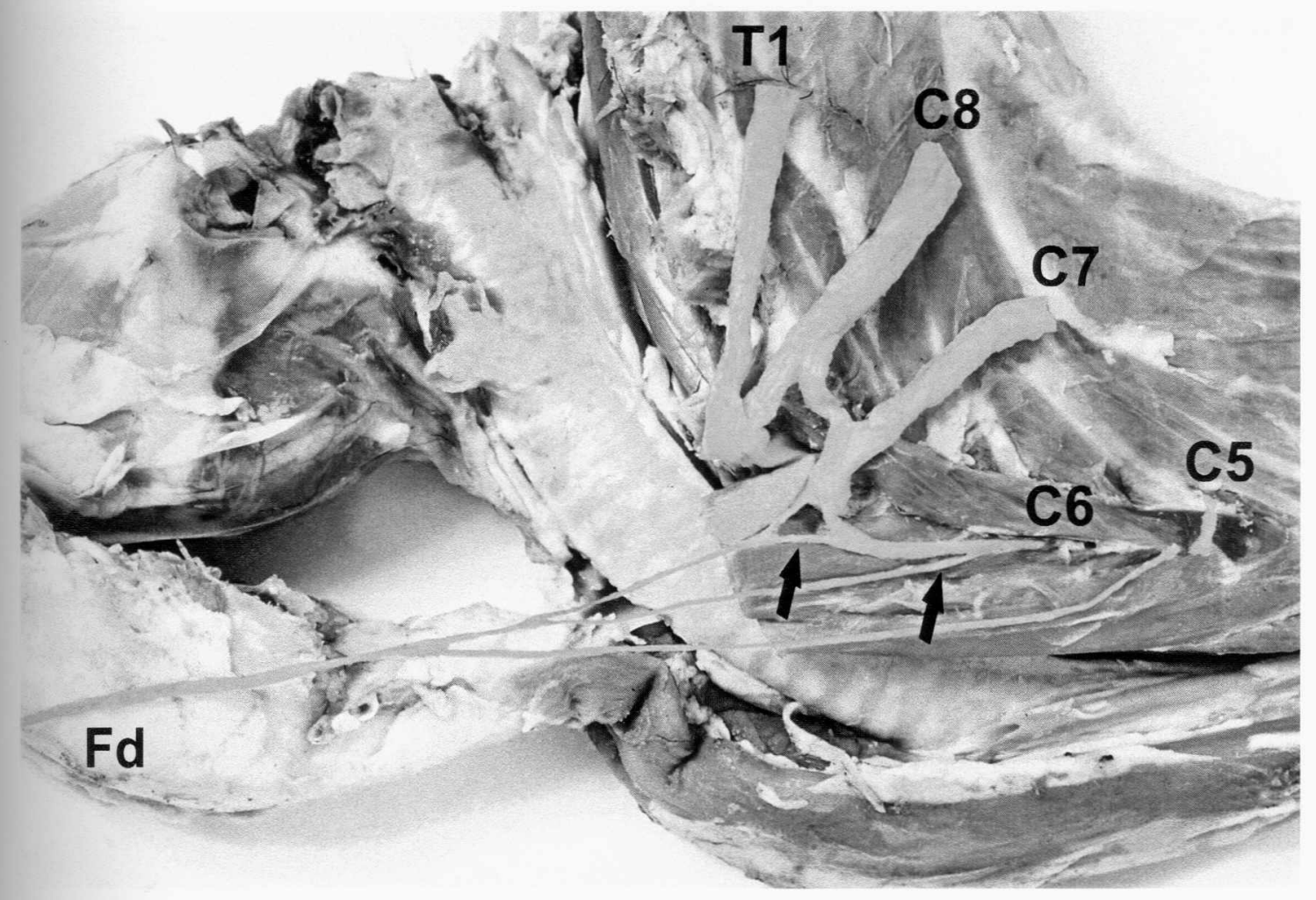

FIGURA 7 -Terço distal da região cervical (vista lateral direita) de ovino da raça Santa Inês (Obs. 16F). O nervo frênico direito $(\mathbf{F d})$ origina-se de três raízes procedentes dos ramos ventrais do $5^{\circ}(\mathbf{C 5}), 6^{\circ}(\mathbf{C 6})$ e $7^{\circ}(\mathbf{C} 7)$ nervos espinhais cervicais. $\mathbf{C} \mathbf{5}$ e $\mathbf{C 7}$ contribuem com um único filete nervoso e $\mathbf{C 6}$ com dois filetes (setas); C8 - $8^{\circ}$ nervo espinhal cervical; T1 - $1^{\circ}$ nervo espinhal torácico. 


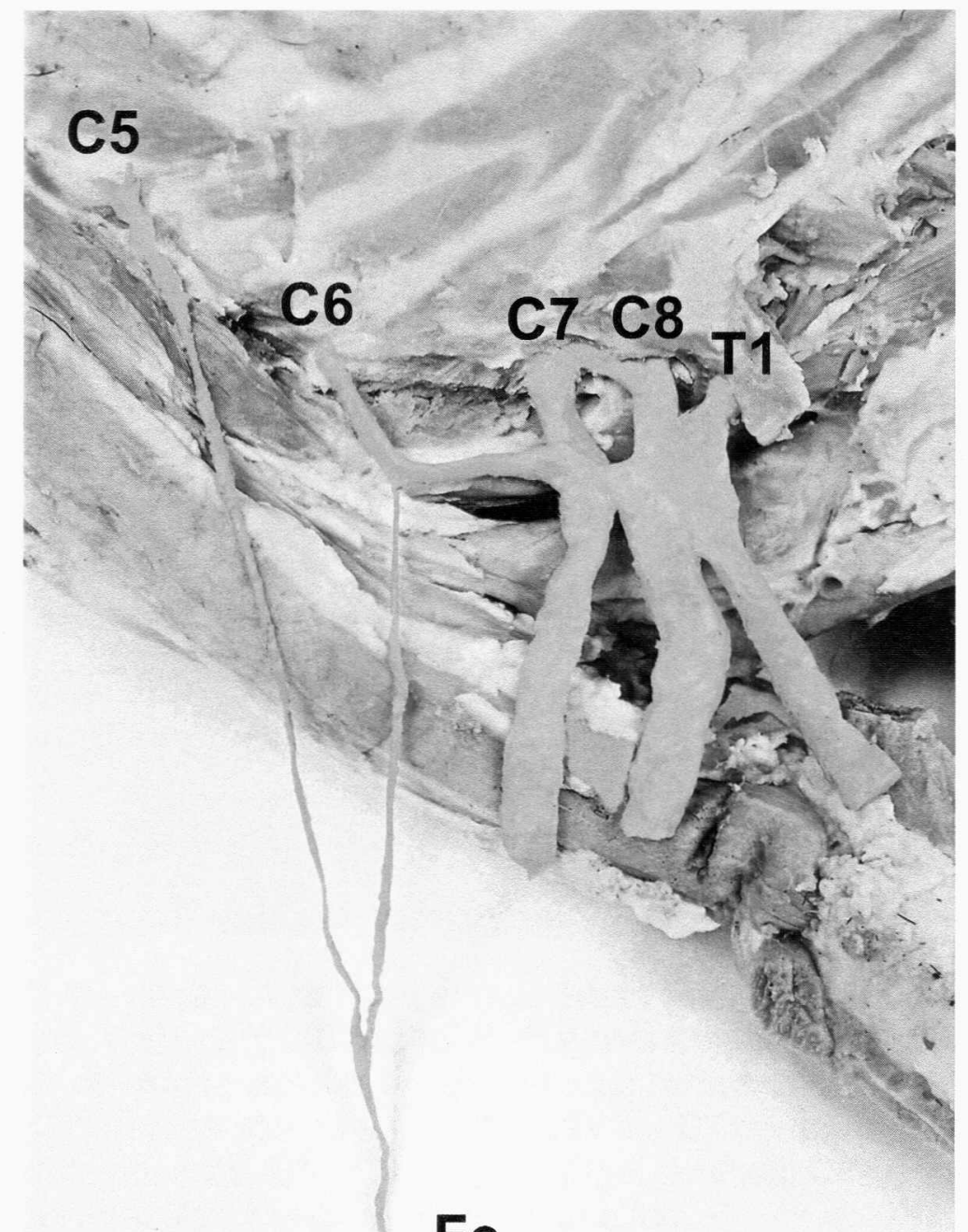

$\mathrm{Fe}$

FIGURA 8 -Terço distal da região cervical (vista lateral esquerda) de ovino da raça Santa Inês (Obs. 10M). O nervo frênico esquerdo (Fe) originase de duas raízes procedentes dos ramos ventrais do $5^{\circ}$ (C5) e $6^{\circ}$ (C6) nervos espinhais cervicais. $\mathbf{C 5}$ e $\mathbf{C 6}$ contribuem com um único filete nervoso. $\mathbf{C} 7-7^{\circ}$ nervo espinhal cervical; $\mathbf{C} 8$ - $8^{\circ}$ nervo espinhal cervical; 11 - $1^{\circ}$ nervo espinhal torácico. 


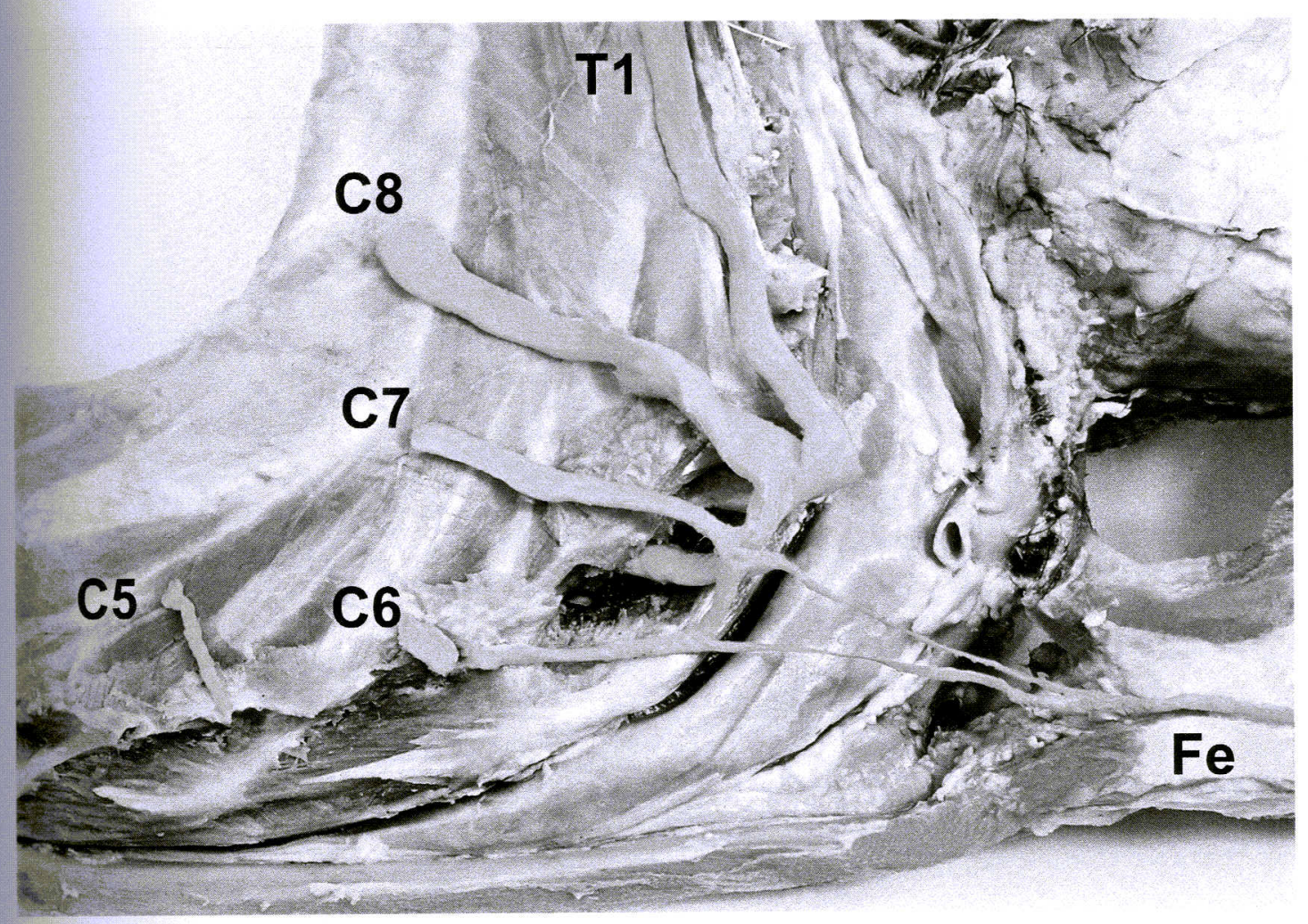

FIGURA 9 -Terço distal da região cervical (vista lateral esquerda) de ovino da raça Santa Inês (Obs. 18M). O nervo frênico esquerdo (Fe) originase de duas raízes procedentes dos ramos ventrais do $6^{\circ}(\mathbf{C} 6)$ e $7^{\circ}$ (C7) nervos espinhais cervicais. $\mathbf{C} \mathbf{6}$ e $\mathbf{C 7}$ contribuem com um único filete nervoso. $\mathbf{C 5}$ - $5^{\circ}$ nervo espinhal cervical; $\mathbf{C 8}$ - $8^{\circ}$ nervo espinhal cervical; T1 - $1^{\circ}$ nervo espinhal torácico. 


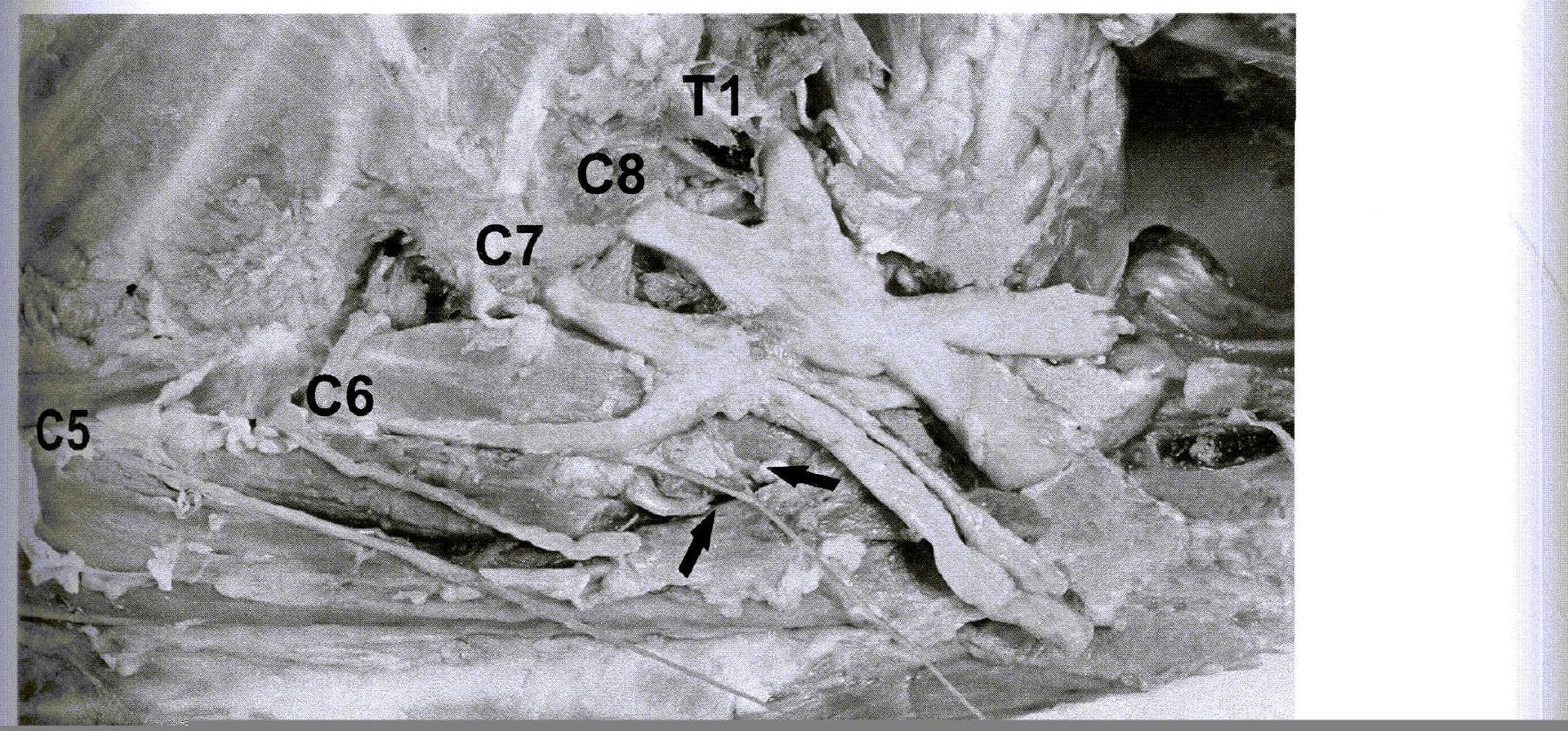




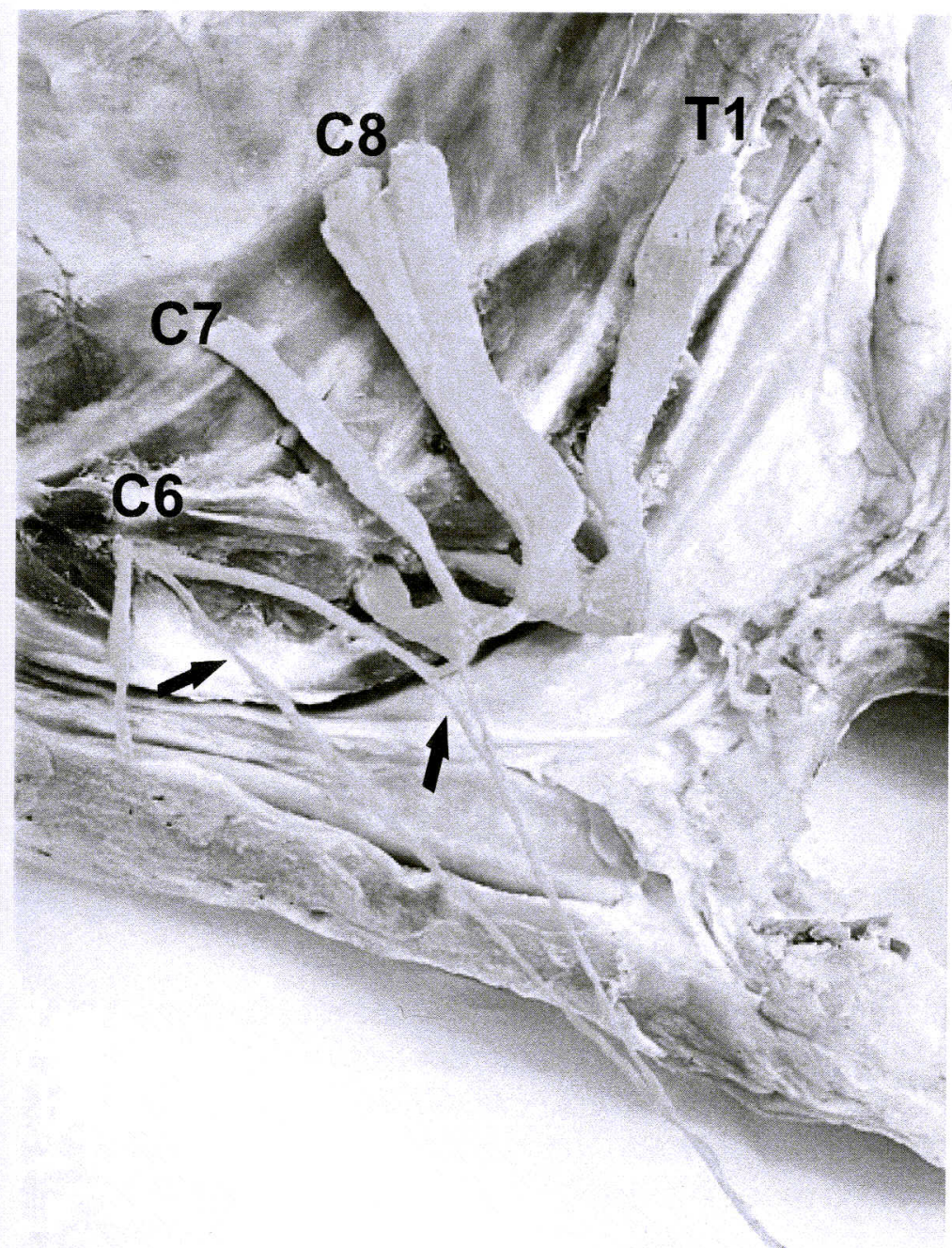

$\mathrm{Fe}$

FIGURA 11 -Terço distal da região cervical (vista lateral esquerda) de ovino da raça Santa inês ('Obs. 23ivi'). U nervo trênico esquerdo ( $\mathrm{Fe}$ ) originase de duas raízes procedentes dos ramos ventrais do $6^{\circ}(\mathbf{C 6})$ e $7^{\circ}$ (C7) nervos espinhais cervicais. $\mathbf{C 7}$ contribui com um único filete nervoso e $\mathbf{C 6}$ com dois filetes (setas). $\mathbf{C 8}-8^{\circ}$ nervo espinhal cervical; $\mathrm{T} 1-1^{\circ}$ nervo espinhal torácico. 


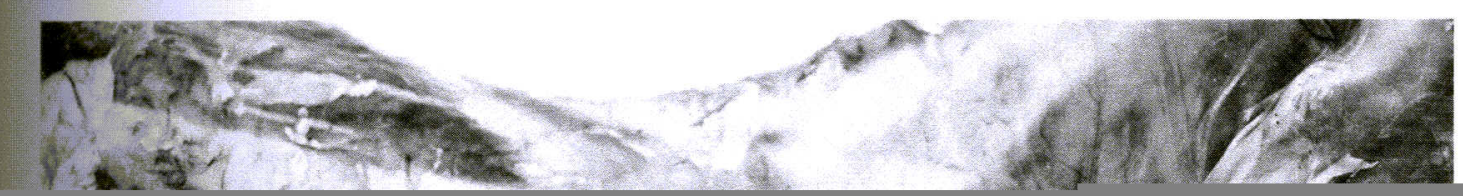




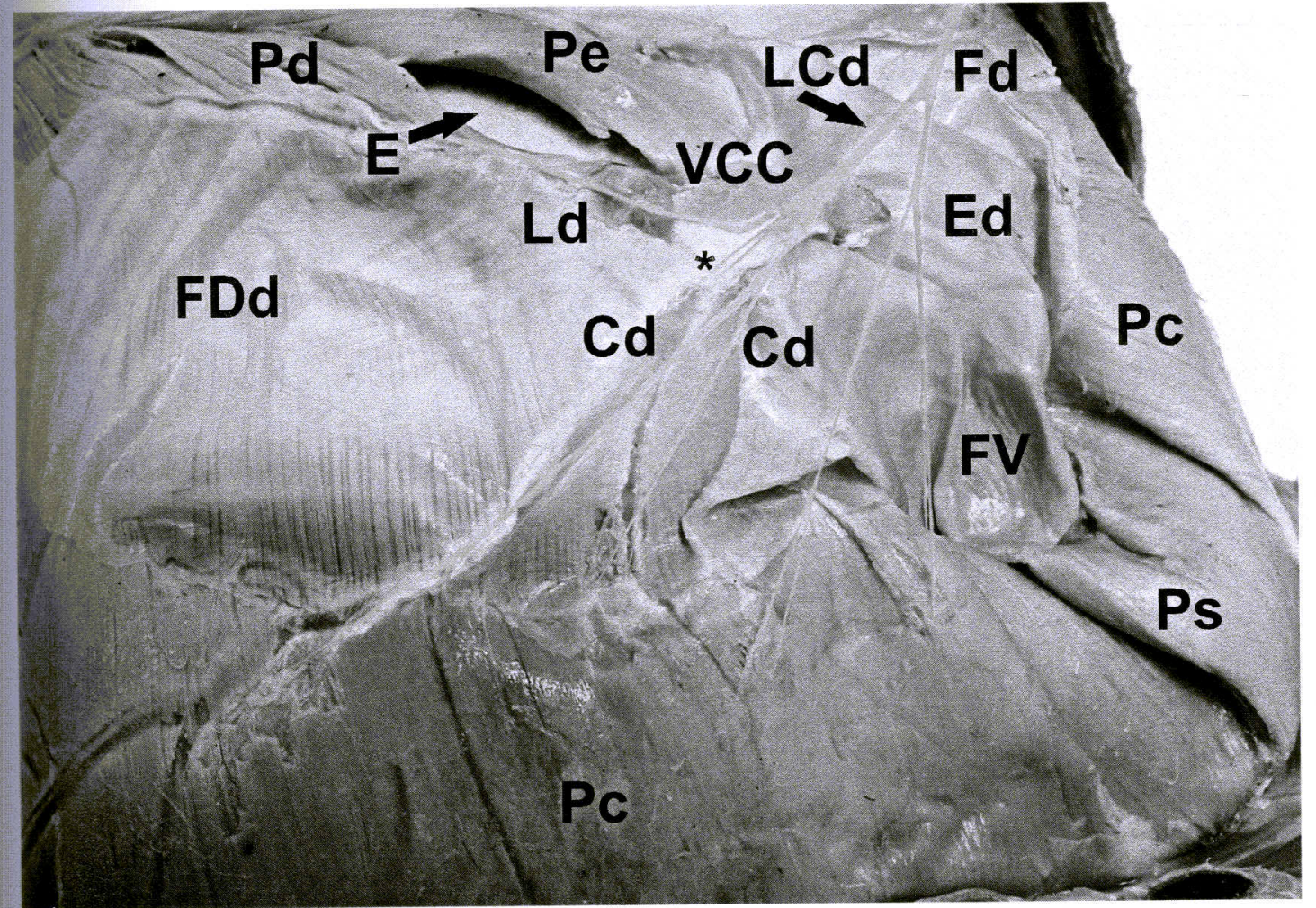

FIGURA 14 -Diafragma (face torácica) de ovino da raça Santa Inês (Obs. 28M), observando-se o nervo frênico direito $(\mathbf{F d})$ a fornecer $o$ tronco lombocostal direito $(\mathbf{L C d})$ e ramo esternal direito $(\mathbf{E d})$. Do tronco lombocostal destacam-se o ramo lombar direito (Ld) e ramo costal direito (Cd); FDd - folíolo dorsal direito; Pd - pilar direito; Pe - pilar esquerdo; E - hiato esofágico; VCC - veia cava caudal; FV - folíolo ventral; Pc - pars costalis; Ps - pars sternalis. Note-se o ramo lombar direito (Ld) a emitir filete nervoso $\left(^{*}\right)$ à veia cava caudal (VCC). 


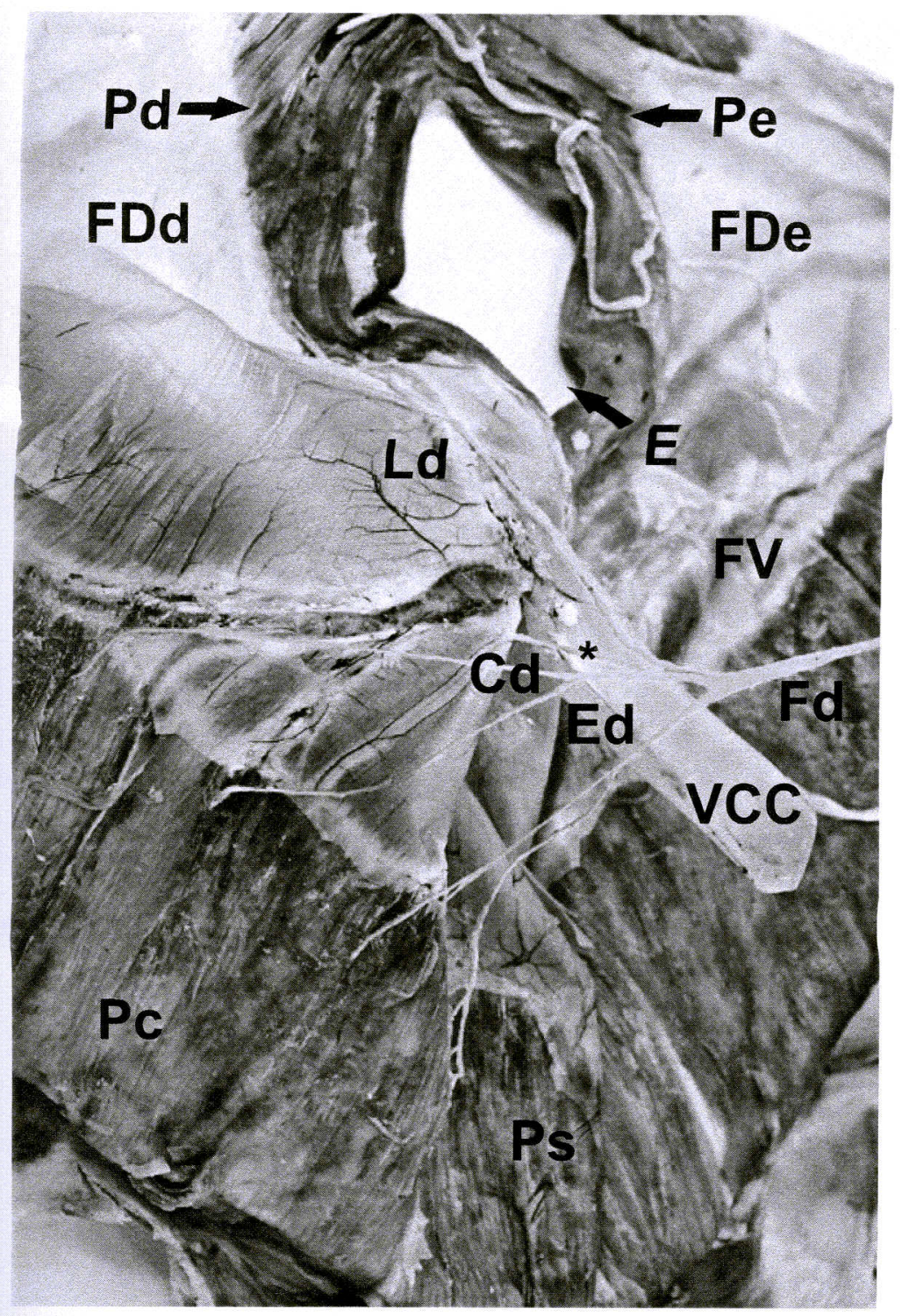

FIGURA 15 - Diafragma (face torácica) de ovino da raça Santa Inês (Obs. 29M), observando-se o nervo frênico direito ( $F \mathbf{d})$ a resolver-se simultaneamente em ramos lombar direito (Ld), costal direito $(\mathbf{C d})$ e esternal direito (Ed). O ramo lombar direito (Ld) distribui-se exclusivamente no pilar direito $(\mathbf{P d})$; o ramo costal direito $(\mathbf{C d})$ alcança as regiões dorsal e ventral da pars costalis $(\mathbf{P c})$, emitindo também filete nervoso $\left(^{*}\right)$ ao folíolo ventral (FV) enquanto o ramo esternal direito $(\mathbf{E d})$ dirige-se à pars sternalis $(\mathbf{P s})$ e à região ventral da pars costalis (Pc). FDd - folíolo dorsal direito; FDe - folíolo dorsal esquerdo; Pe - pilar esquerdo; E - hiato esofágico; VCC - veia cava caudal. 


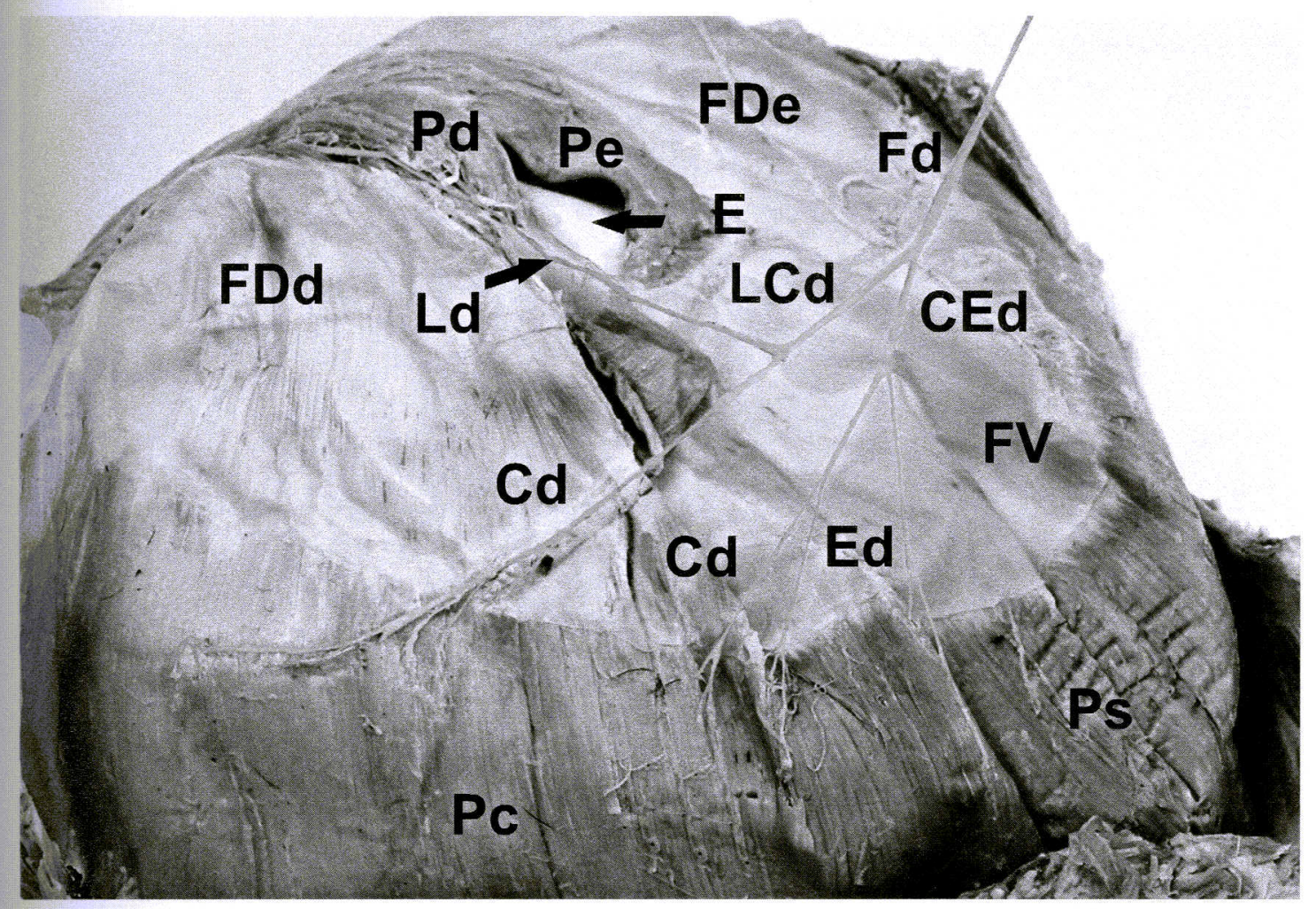

FIGURA 16 -Diafragma (face torácica) de ovino da raça Santa Inês (Obs. 12M), observando-se o nervo frênico direito (Fd) a dividir-se concomitantemente em troncos lombocostal direito (LCd) e costoesternal direito (CEd). Do tronco lombocostal partem o ramo lombar direito (Ld) e o ramo costal direito $(\mathbf{C d})$. Do tronco costoesternal partem o ramo costal direito (Cd) e o ramo esternal direito (Ed); FDd - folíolo dorsal direito; FDe - folíolo dorsal esquerdo; Pd - pilar direito; $\mathbf{P e}$ pilar esquerdo; E - hiato esofágico; FV - folíolo ventral; Pc - pars costalis; Ps - pars sternalis. 


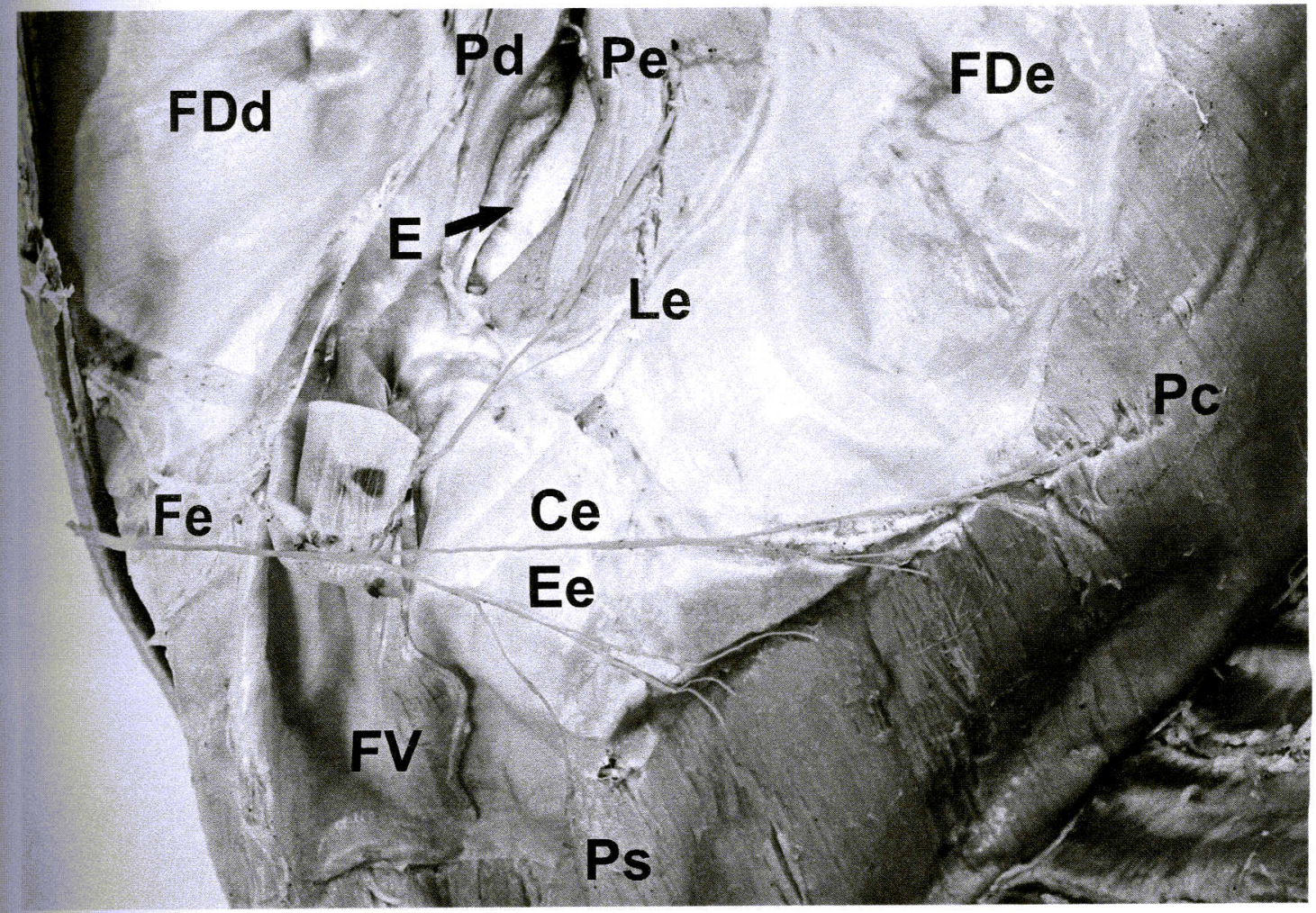

FIGURA 17 -Diafragma (face torácica) de ovino da raça Santa Inês (Obs. 21F), observando-se o nervo frênico esquerdo (Fe) a emitir simultaneamente os ramos lombar esquerdo (Le), costal esquerdo $(\mathbf{C e})$ e esternal esquerdo (Ee). O ramo lombar esquerdo (Le) distribui-se apenas no pilar esquerdo $(\mathbf{P e})$, o ramo costal esquerdo alcança as regiões dorsal e ventral da pars costalis $(\mathbf{P c})$ e o ramo esternal esquerdo dirige-se à pars sternalis (Ps) e à região ventral da pars costalis (Pc); FDd - folíolo dorsal direito; FDe - folíolo dorsal esquerdo; Pd - pilar direito; $\mathbf{P e}$ - pilar esquerdo; E - hiato esofágico; FV - folíolo ventral. 


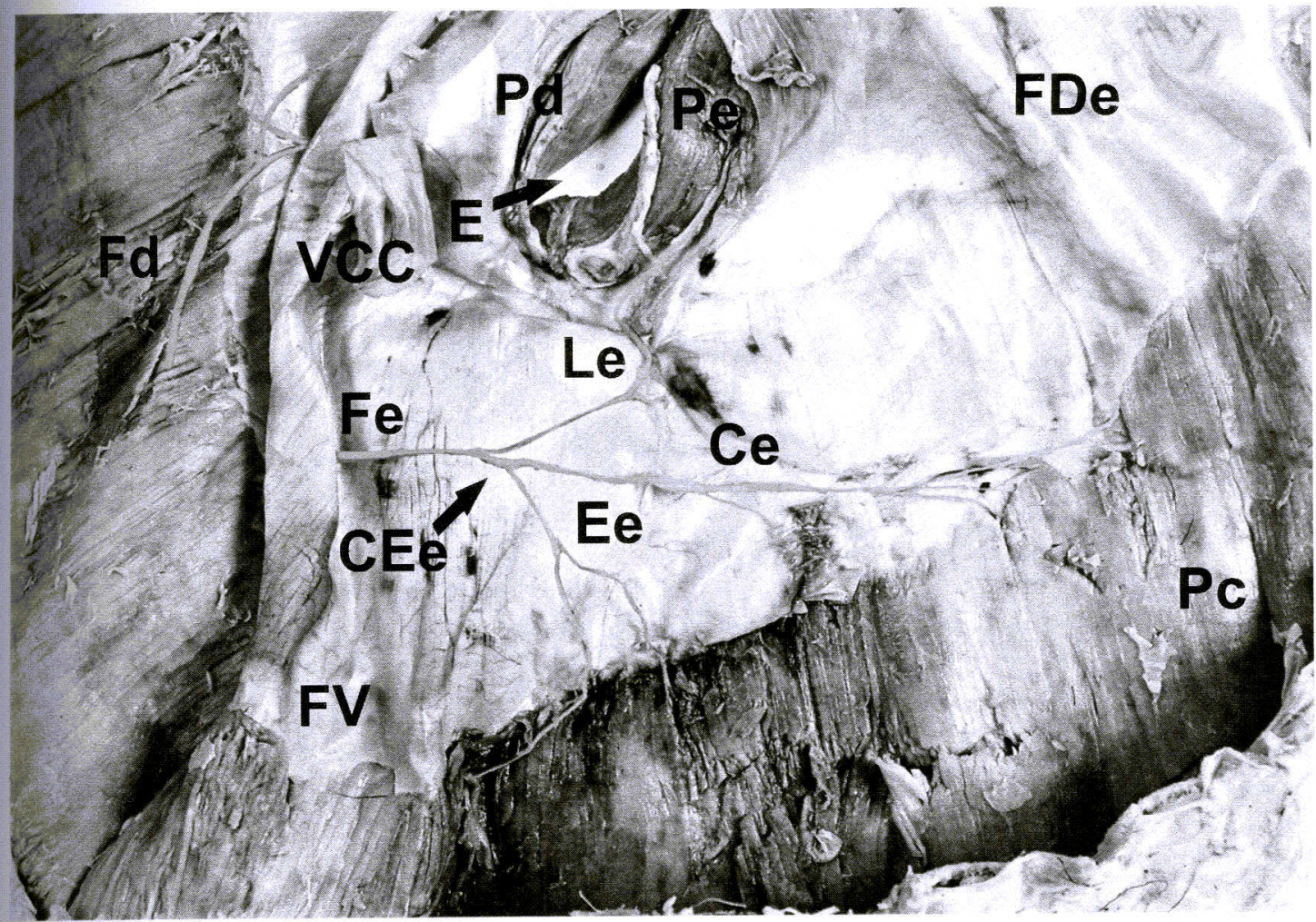

FIGURA 18 - Diafragma (face torácica) de ovino da raça Santa Inês (Obs. 4M), observando-se o nervo frênico esquerdo $(\mathbf{F e})$ a dividir-se em ramo lombar esquerdo (Le) e tronco costoesternal esquerdo (CEe). Do tronco costoesternal derivam o ramo costal esquerdo $(\mathbf{C e})$ e o ramo esternal esquerdo (Ee); Fd - nervo frênico direito; $\mathbf{P d}$ - pilar direito; Pe - pilar esquerdo; E - hiato esofágico; VCC - veia cava caudal; FDe - folíolo dorsal esquerdo; FV - folíolo ventral; Pc - pars costalis; Ps - pars sternalis. 


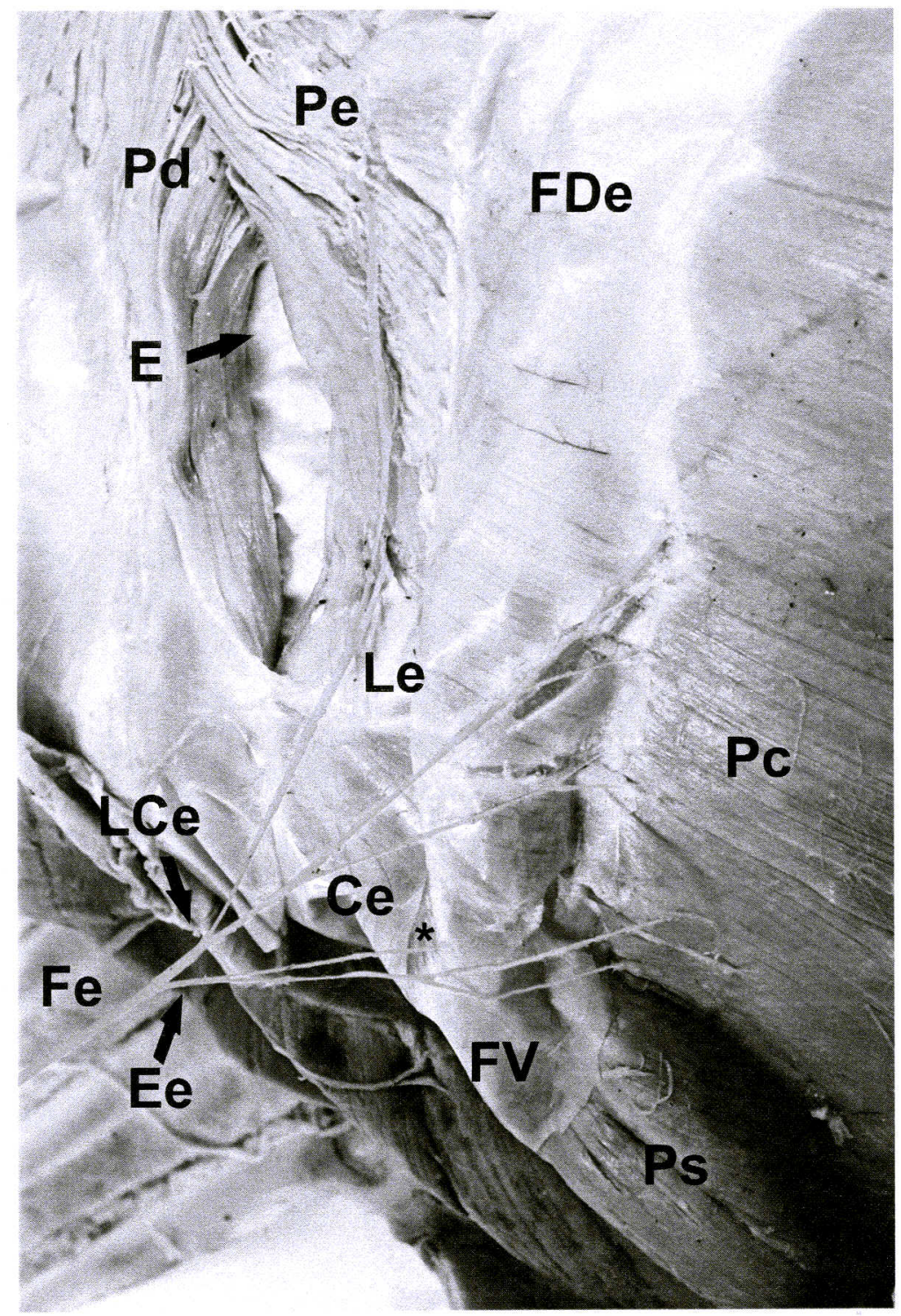

FIGURA 19 - Diafragma (face torácica) de ovino da raça Santa Inês (Obs. 27M), observando-se o nervo frênico esquerdo $(\mathbf{F e})$ a fornecer o tronco lombocostal esquerdo (LCe) e o ramo esternal esquerdo (Ee). Do tronco lombocostal destacam-se o ramo lombar esquerdo (Le) e o ramo costal esquerdo (Ce); Pd - pilar direito; $\mathbf{P e}$ - pilar esquerdo; FDe - folíolo dorsal esquerdo; E - hiato esofágico; FV - folíolo ventral; Pc - pars costalis; Ps - pars sternalis. Note-se o ramo esternal esquerdo(Ee) a emitir filete nervoso $\left({ }^{*}\right)$ para uma pequena área circular muscular localizada no folíolo ventral (FV). 


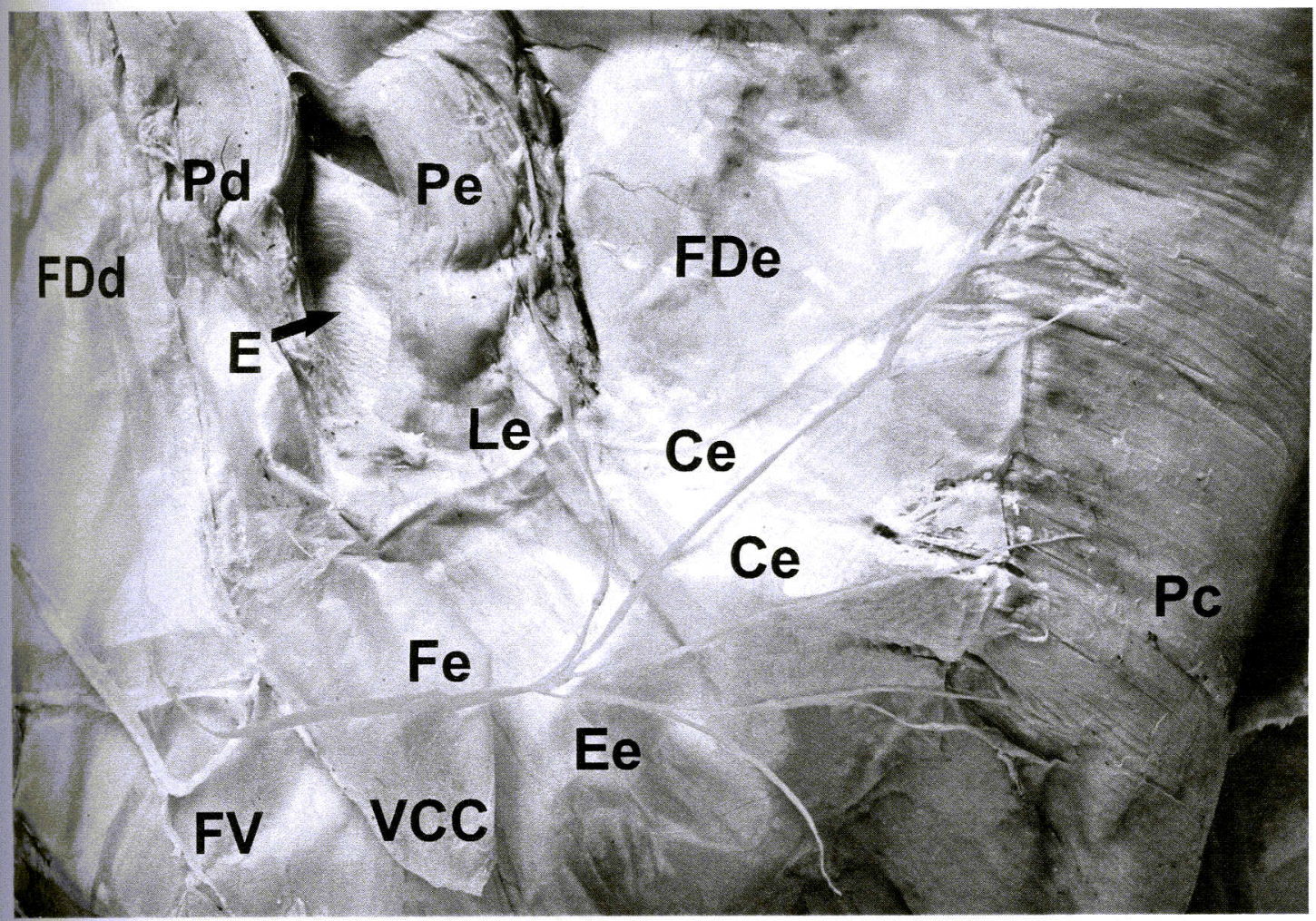

FIGURA 20 -Diafragma (face torácica) de ovino da raça Santa Inês (Obs. 9M), observando-se o nervo frênico esquerdo $(\mathbf{F e})$ cedendo simultaneamente os ramos lombar esquerdo (Le), costal esquerdo (Ce), em número de dois, e esternal esquerdo (Ee); FDd - folíolo dorsal direito; FDe - folíolo dorsal esquerdo; Pd - pilar direito; Pe - pilar esquerdo; E - hiato esofágico; VCC - veia cava caudal; FV -folíolo ventral; Pc-pars costalis. 


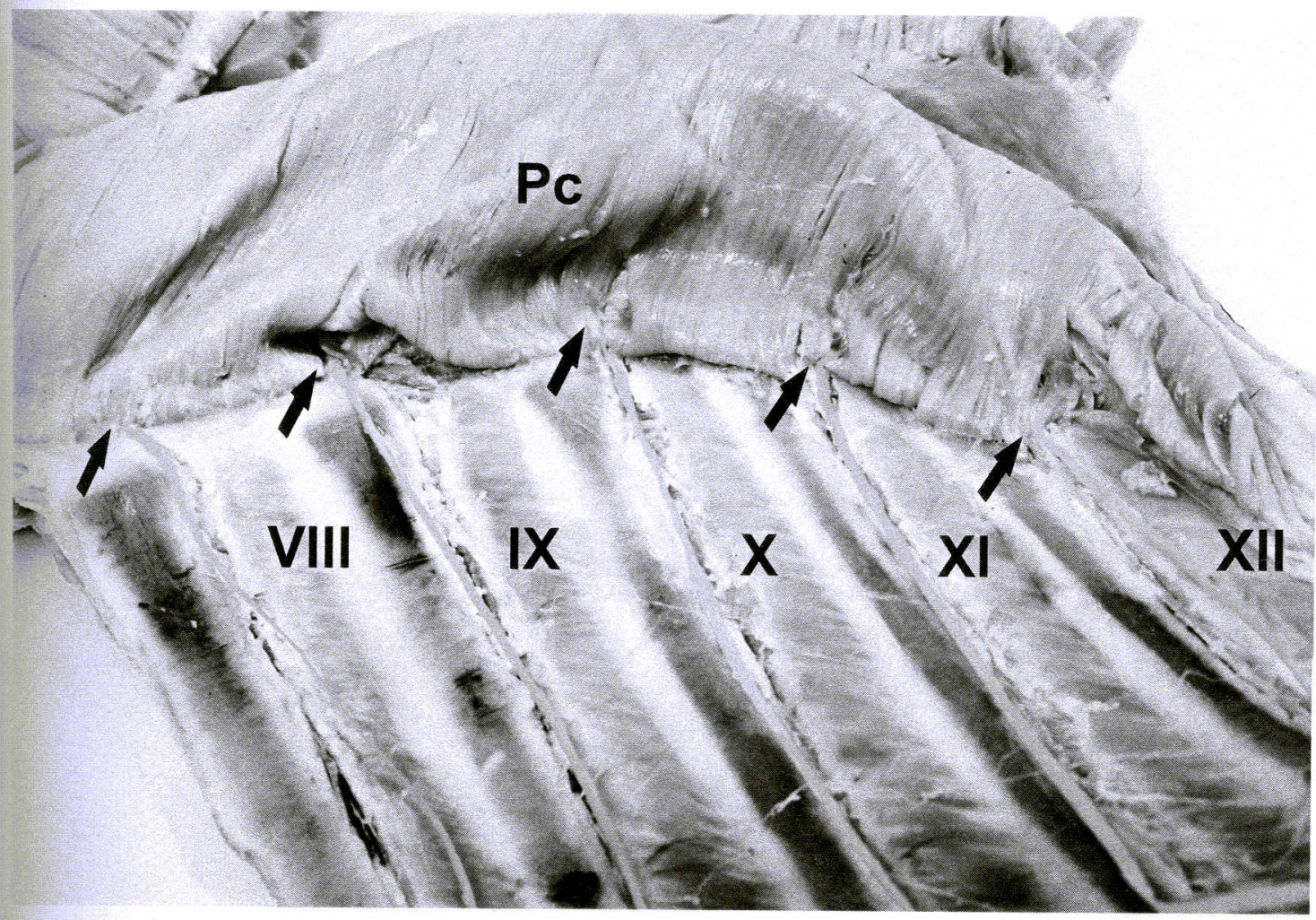

FIGURA 21 - Diafragma (face torácica) de ovino da raça Santa Inês (Obs. 13M), observando-se a contribuição de nervos intercostais (do VIII ao XII pares-setas), em sua inervação; Pc - pars costalis. 


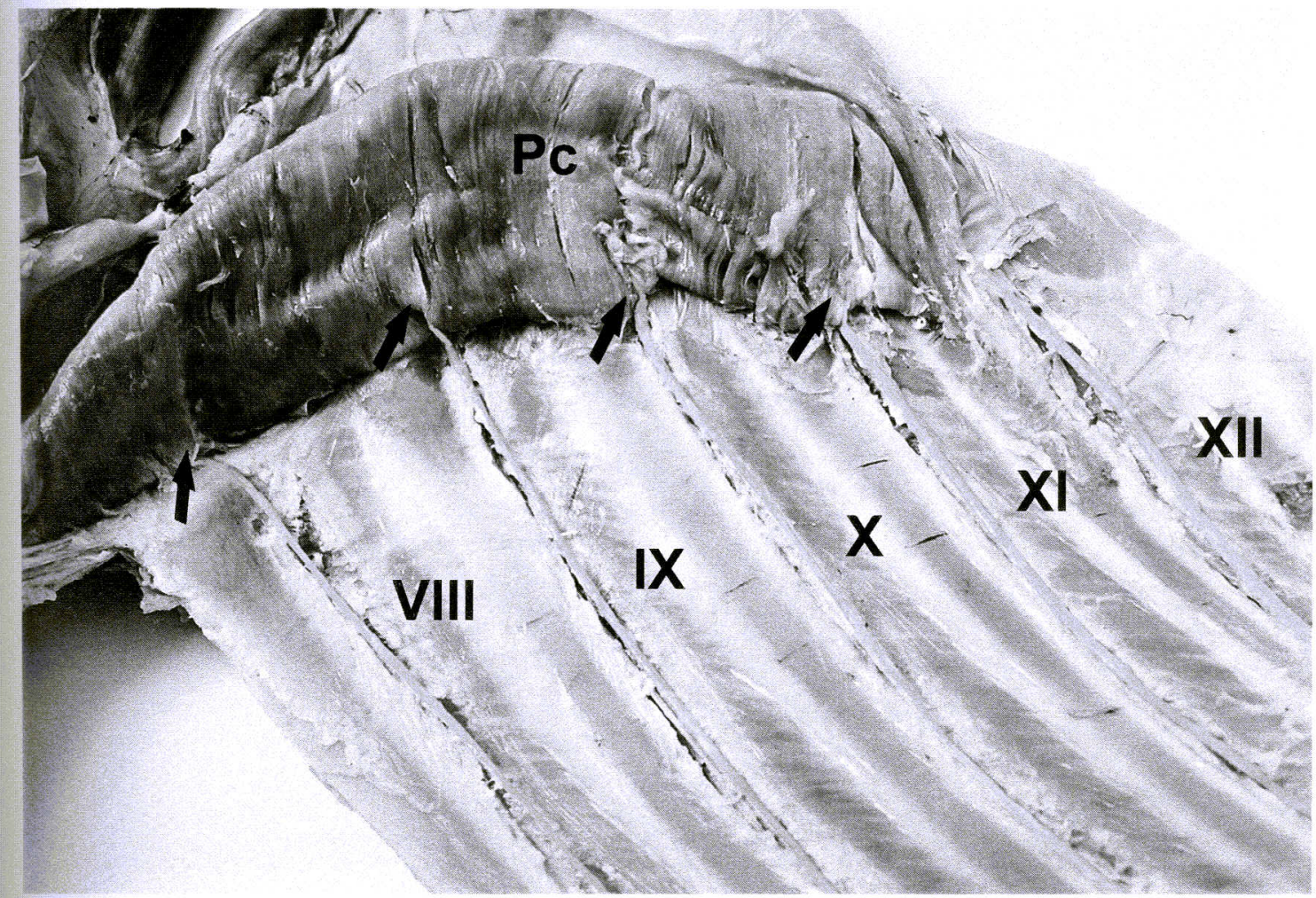

FIGURA 22 - Diafragma (face torácica) de ovino da raça Santa Inês (Obs. 26M), observando-se a contribuição de nervos intercostais (do VIII ao XI pares-setas), em sua inervação à esquerda; $P$ c - pars costalis. 


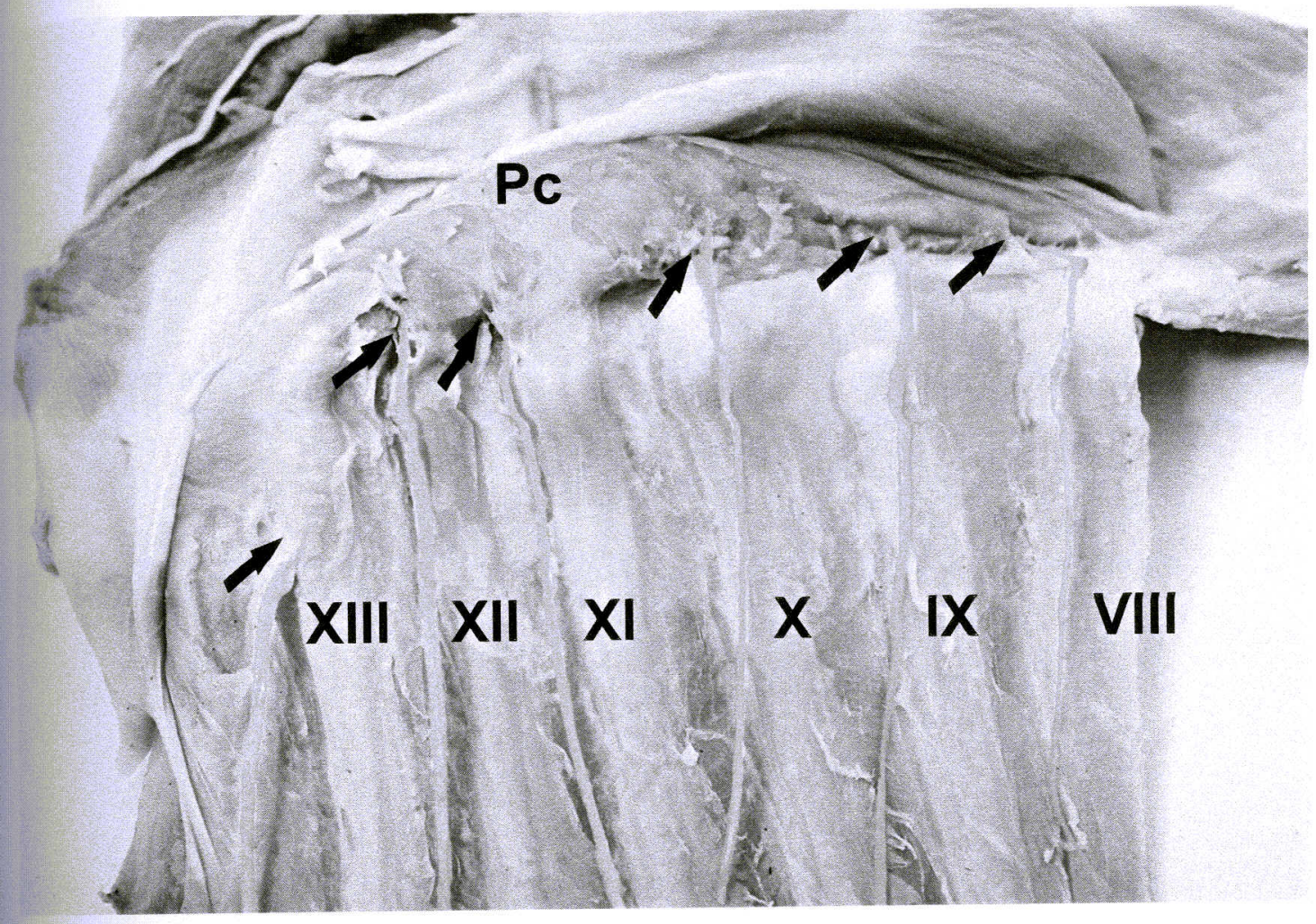

FIGURA 23 - Diafragma (face torácica) de ovino da raça Santa Inês (Obs. 22M), observando-se a contribuição de nervos intercostais (do VIII ao XIII pares- setas), em sua inervação; Pc - pars costalis. 


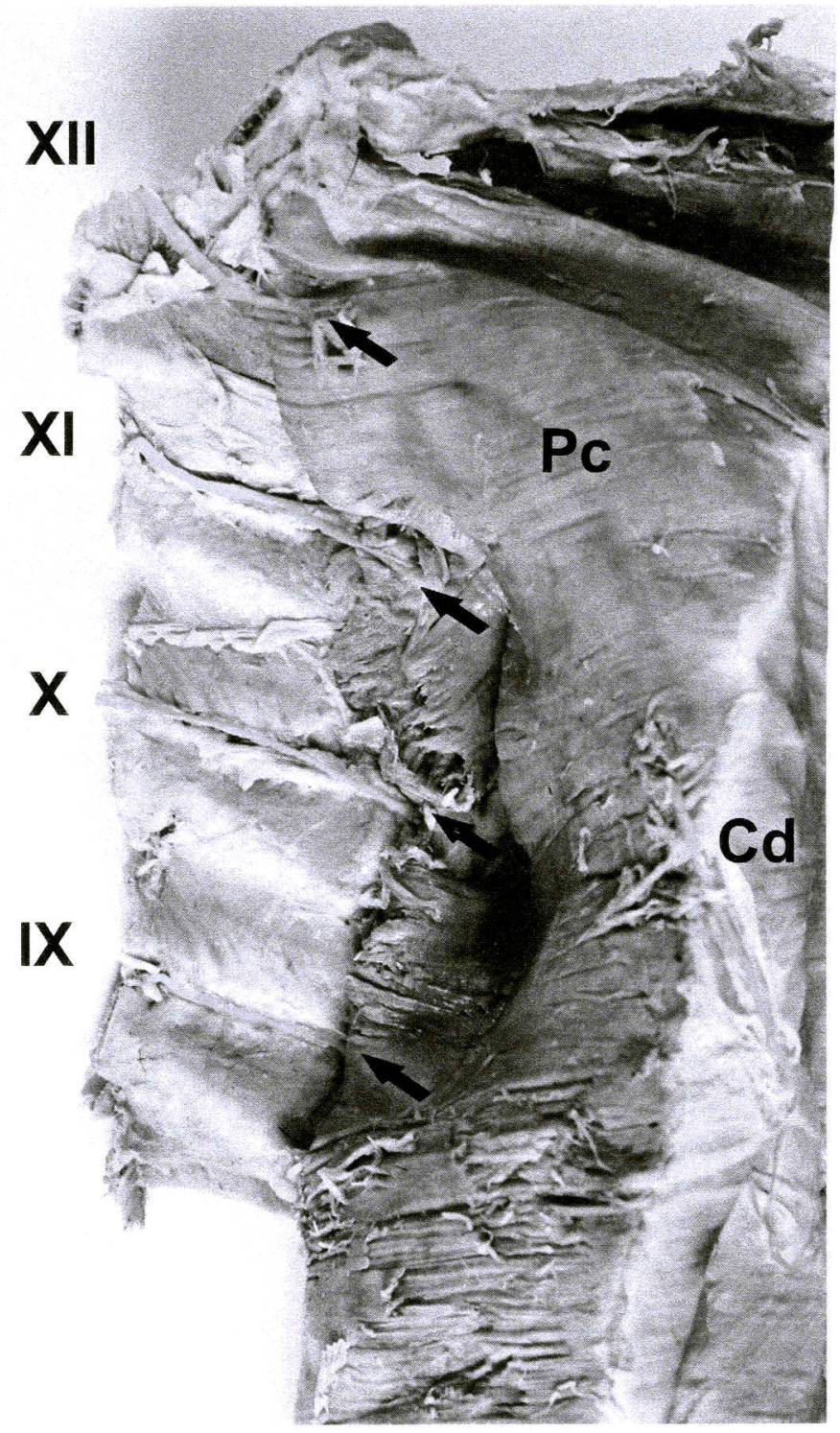

FIGURA 24- Diafragma (face torácica) de ovino da raça Santa Inês (Obs. 4M), observando-se a contribuição de nervos intercostais (do IX ao XII pares-setas), em sua inervação; Pc - pars costalis; Cd - ramo costal direito do nervo frênico direito. 


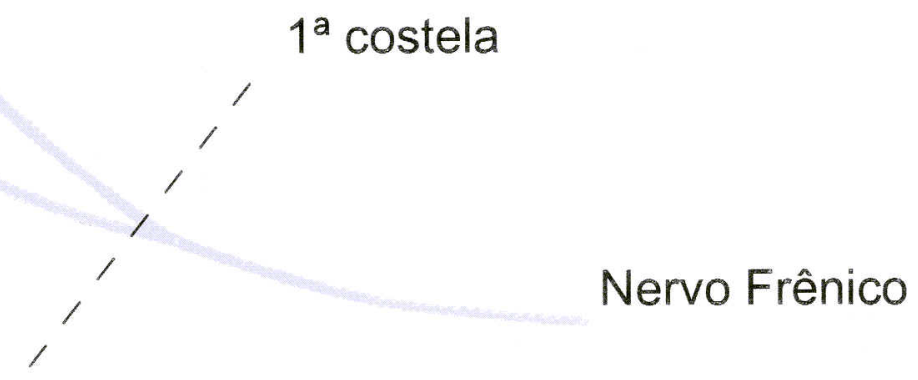

FGURA 25 - Representação esquemática das raizes formadoras dos nervos frênicos direito e esquerdo. Cada nervo espinhal cervical (C5 e C6) contribui com um único filete nervoso, unindo-se em correspondência à $1^{\mathrm{a}}$ costela.

C5

C6

Articulação entre a

$5^{a}$ e $6^{a}$ vértebras

cervicais

Nervo Frênico

FIGURA 26 - Representação esquemática das raízes formadoras dos nervos frênicos direito e esquerdo. Cada nervo espinhal cervical (C5 e C6) contribui com um único filete nervoso, unindo-se em correspondência à articulação entre a $5^{\mathrm{a}}$ e $6^{\mathrm{a}}$ vértebras cervicais. 
C6

$1^{\mathrm{a}}$ costela

Nervo Frênico

FIGURA 27 - Representação esquemática das raízes formadoras dos nervos frênicos direito e esquerdo. Cada nervo espinhal cervical (C6 e C7) contribui com um único filete nervoso, unindo-se em correspondência à $1^{\mathrm{a}}$ costela.

C6

C7

Nervo Frênico

FIGURA 28 - Representação esquemática das raízes formadoras dos nervos frênicos direito e esquerdo. Cada nervo espinhal cervical (C6 e C7) contribui com um único filete nervoso, unindo-se em correspondência à articulação entre a $6^{\mathrm{a}}$ e $7^{\mathrm{a}}$ vértebras cervicais. 
Articulação entre a

$6^{a}$ e $7^{a}$ vértebras

cervicais

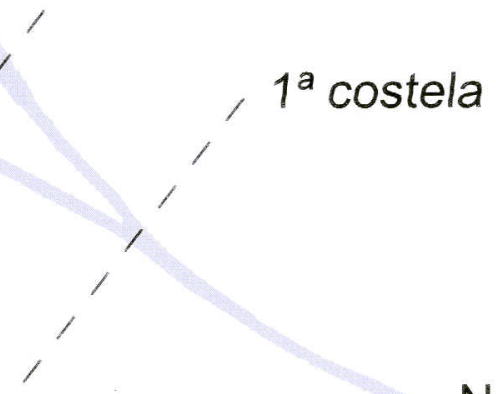

Nervo Frênico

FIGURA 29 - Representação esquemática das raízes formadoras dos nervos frênicos direito e esquerdo. O nervo espinhal cervical C 5 contribui com um único filete nervoso enquanto $\mathrm{C} 6$ contribui com dois filetes. A união do curto filete de C6 com o filete maior ocorre em correspondência à articulação entre a $6^{a}$ e $7^{a}$ vértebras cervicais e o tronco resultante recebe o filete de $\mathrm{C} 5$ ao nível da $1^{\mathrm{a}}$ costela.

C6

C7

Articulação entre a

$6^{a}$ e $7^{a}$ vértebras cervicais

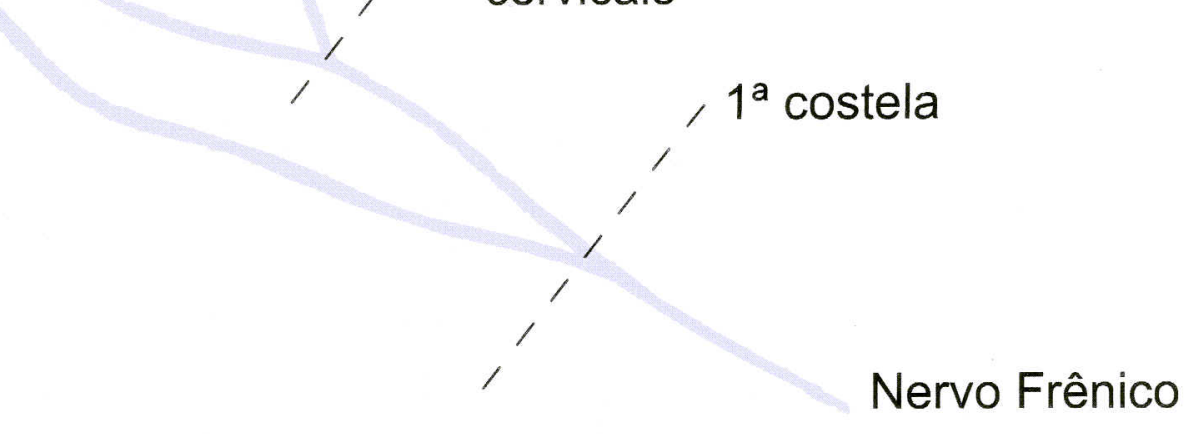

FIGURA 30 - Representação esquemática das raízes formadoras dos nervos frênicos direito e esquerdo. O nervo espinhal cervical C7 contribui com um único filete nervoso enquanto $\mathrm{C} 6$ contribui com 2 filetes. A união do curto filete de $\mathrm{C} 6 \mathrm{com}$ o filete de $\mathrm{C} 7$ processa-se em correspondência à articulação entre a $6^{\mathrm{a}}$ e $7^{\mathrm{a}}$ vértebras cervicais e o tronco resultante recebe ofilete maior de C6 ao nivel da $1^{\mathrm{a}}$ costela. 
FIGURA 31 - Representação esquemática das raízes formadoras dos nervos frênicos direito e esquerdo. Cada nervo espinhal cervical (C5, C6 e C7) contríbui com um único filete nervoso. A união do filete de C6 com o correspondente de C7 ocorre em relação à articulação entre a $6^{\mathrm{a}}$ e $7^{\mathrm{a}}$ vértebras cervicais enquanto a união do tronco resultante com o filete de C5 processa-se ao nível da $1^{\mathrm{a}}$ costela.

C5

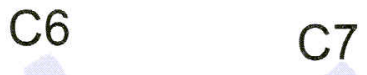

Articulação entre a $6^{a}$ e $7^{a}$ vértebras cervicais

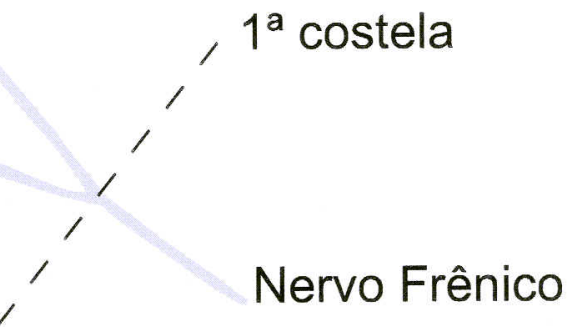

FIGURA 32 - Representação esquemática das raízes formadoras do nervo frênico direito. O nervo espinhal cervical C6 contribui com 2 filetes nervosos. A união do curto filete de $\mathrm{C} 6 \mathrm{com}$ o filete de $\mathrm{C} 7$ ocorre em correspondência à articulação entre a $6^{\mathrm{a}}$ e $7^{\mathrm{a}}$ vértebras cervicais; o tronco resultante une-se ao filete maior de C6 também a esse nível enquanto o filete de C5 é incorporado em relação à $1^{\mathrm{a}}$ costela. 
Articulação entre a

$5^{\mathrm{a}}$ e $6^{\mathrm{a}}$ vértebras cervicais

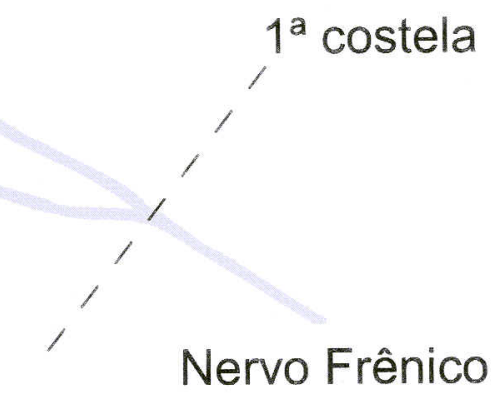

FIGURA 35 - Representação esquemática das raízes formadoras do nervo frênico esquerdo. O filete nervoso de C5 une-se ao correspondente de $C 7$ em relação à articulação entre a $5^{a}$ e $6^{a}$ vértebras cervicais e o tronco resultante recebe o filete de $\mathrm{C} 6$ ao nível da $1^{a}$ costela.

C6

\section{Nervo Frênico}

FIGURA 36 - Representação esquemática da raiz formadora do nervo frênico esquerdo. O nervo mostra-se procedente de uma raiz, ou seja, do filete nervoso oriundo do $6^{\circ}$ nervo espinhal cervical. 
FIGURA 37 - Esquemas (correspondentes às Obs. de 1 a 30 ) representativos da ramificação e distribuição dos nervos frênicos direito e esquerdo no diafragma (face torácica) de ovinos da raça Santa Inês.
Fd - nervo frênico direito
Fe - nervo frênico esquerdo
LCd - tronco lombocostal direito
LCe - tronco lombocostal esquerdo
CEd - tronco costoesternal direito
CEe - tronco costoesternal esquerdo
Ld - ramo lombar direito
Le - ramo lombar esquerdo
Cd - ramo costal direito
Ce - ramo costal esquerdo
Ed - ramo esternal direito
Ee - ramo esternal esquerdo
Ic - nervos intercostais
VII - XIII - pares de costelas 


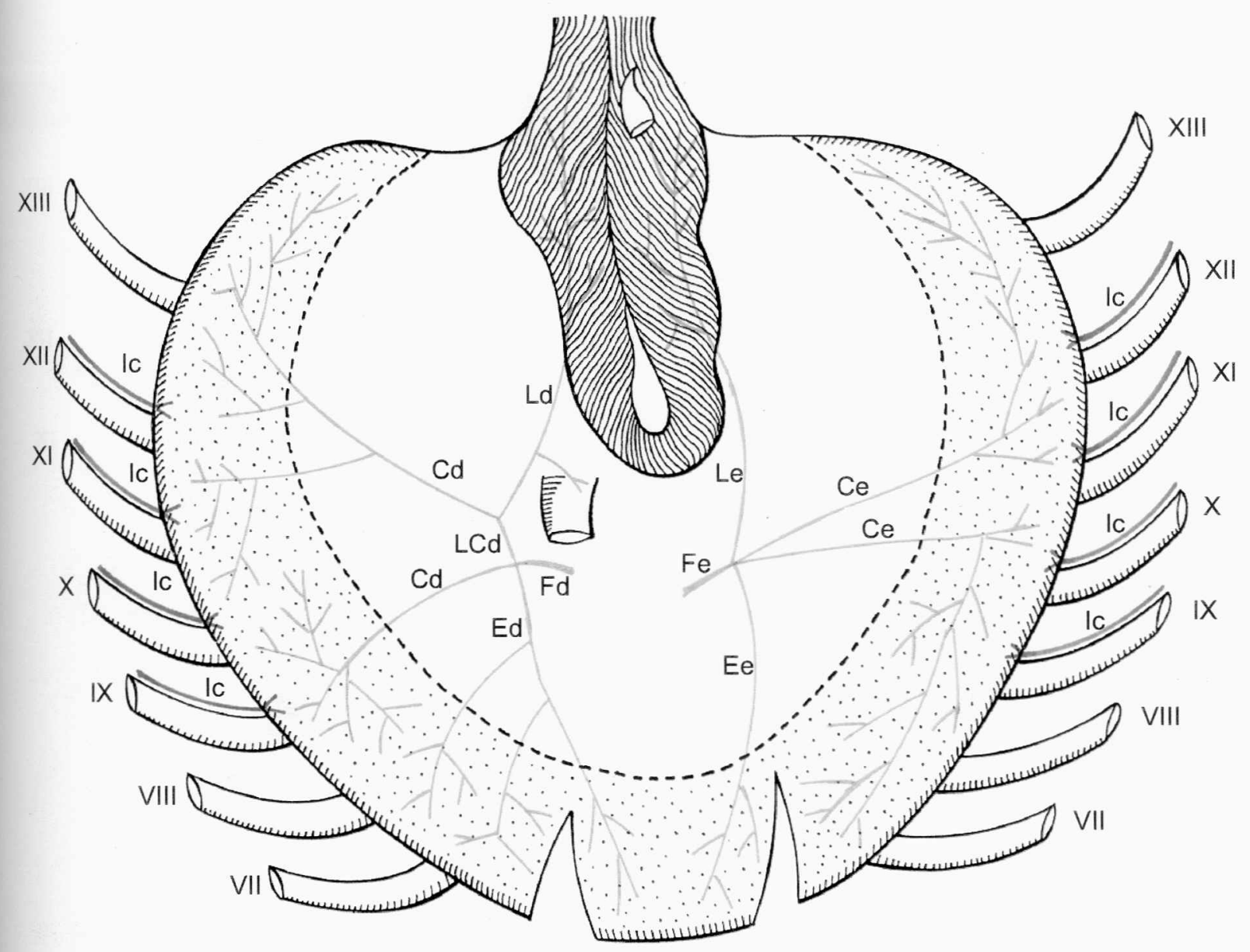

Obs. 1M 


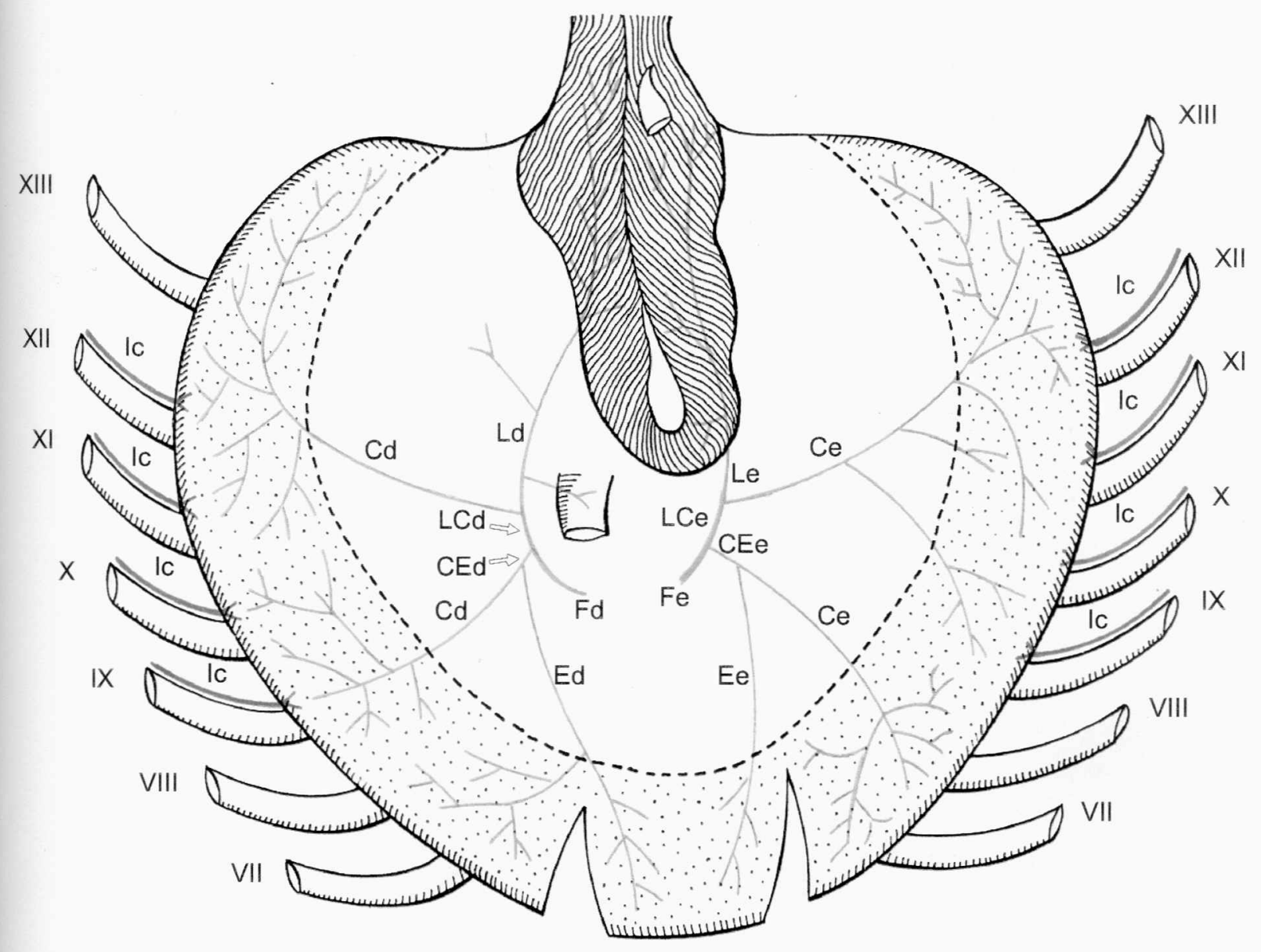

Obs. $2 \mathrm{M}$ 


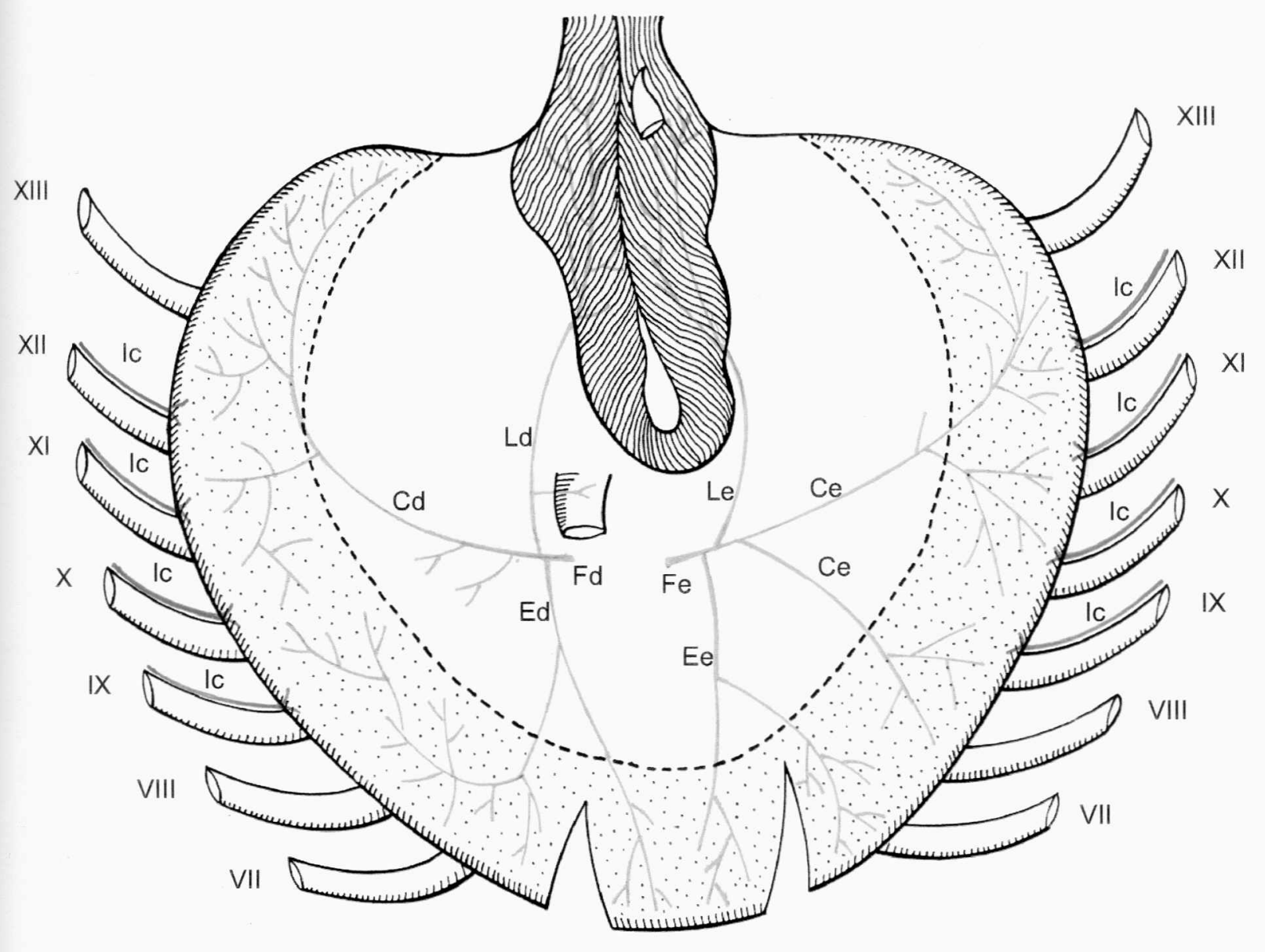

Obs. 3F 


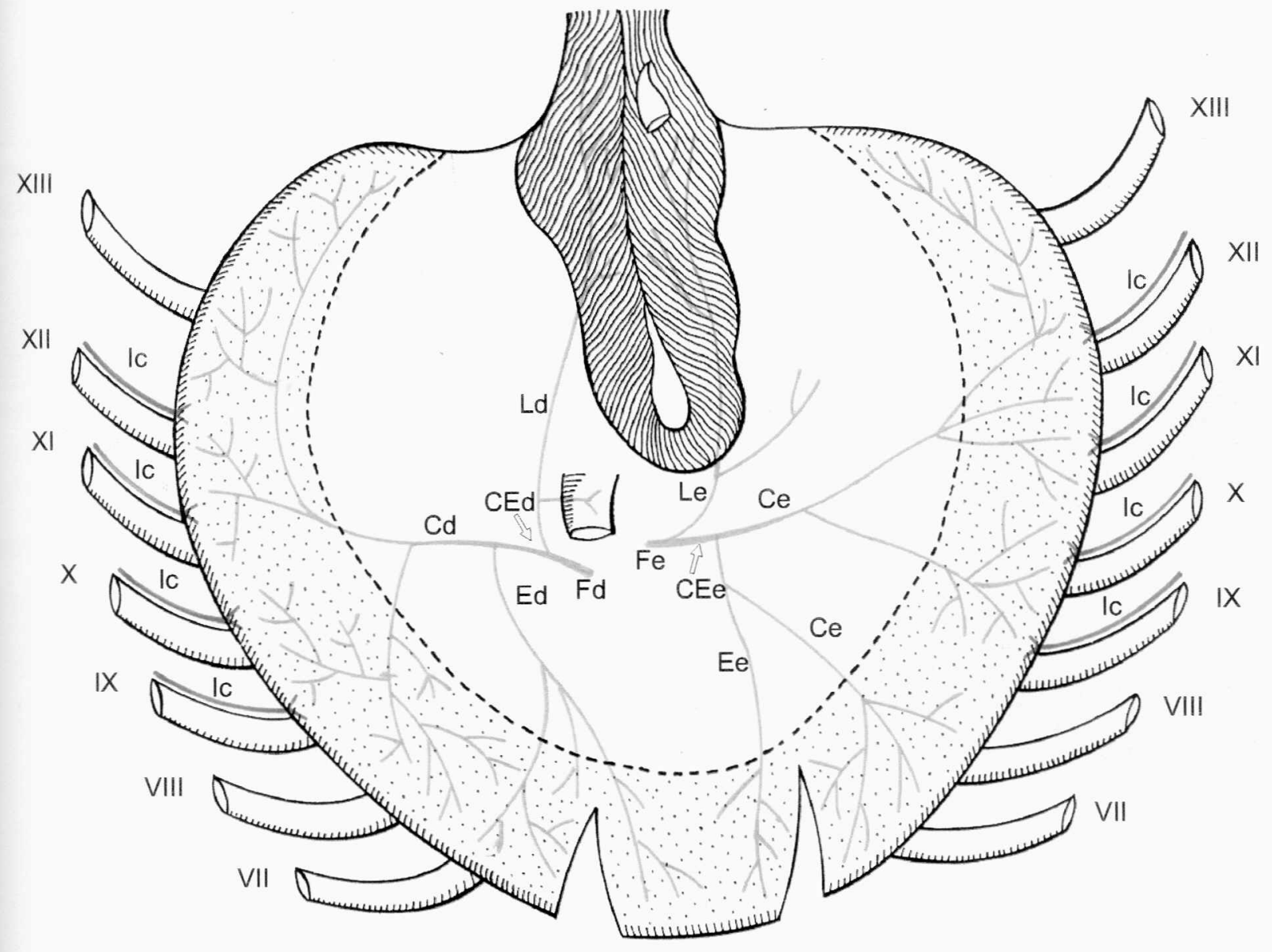

Obs. $4 \mathrm{M}$ 


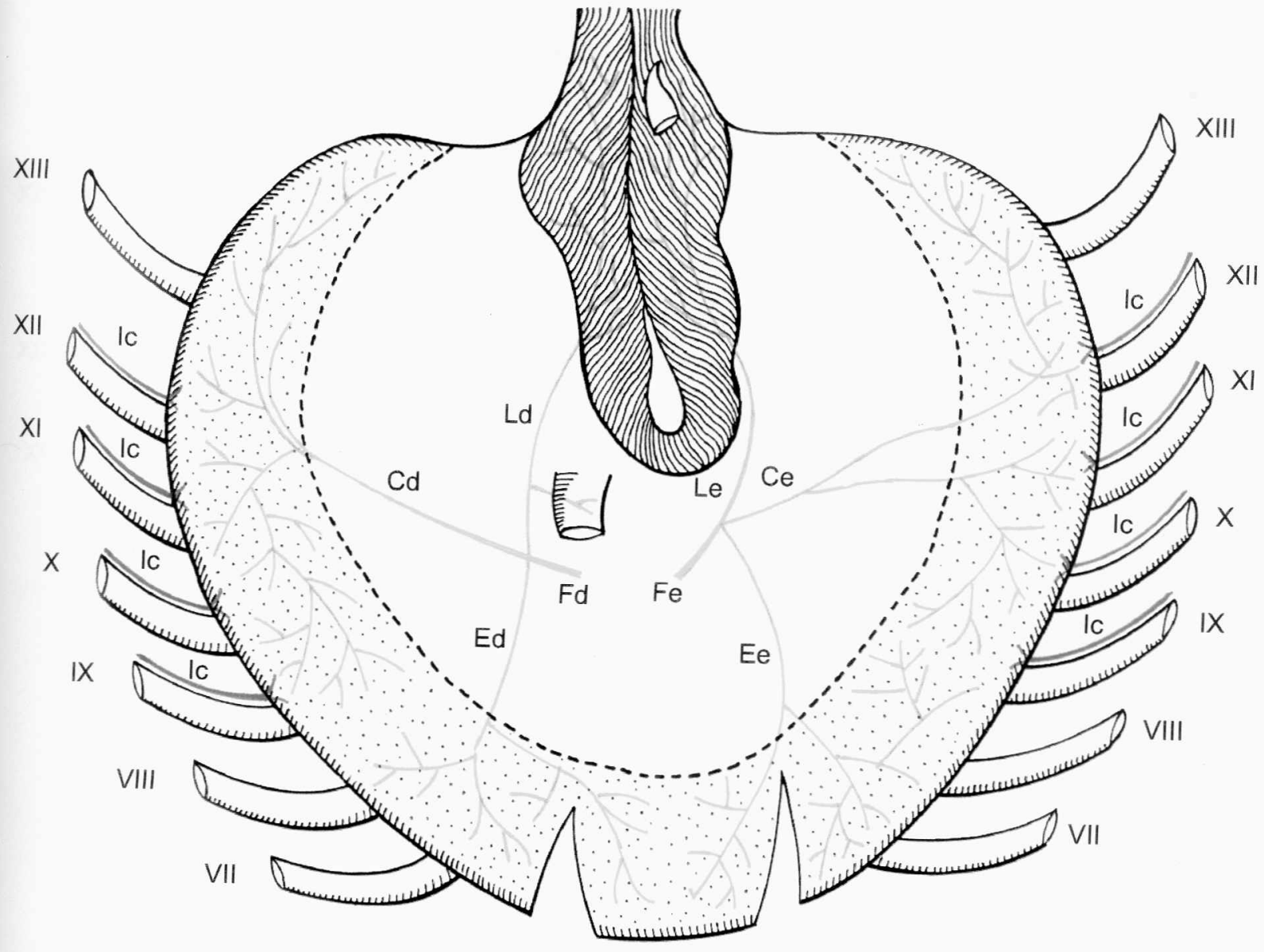

Obs. $5 \mathrm{M}$ 


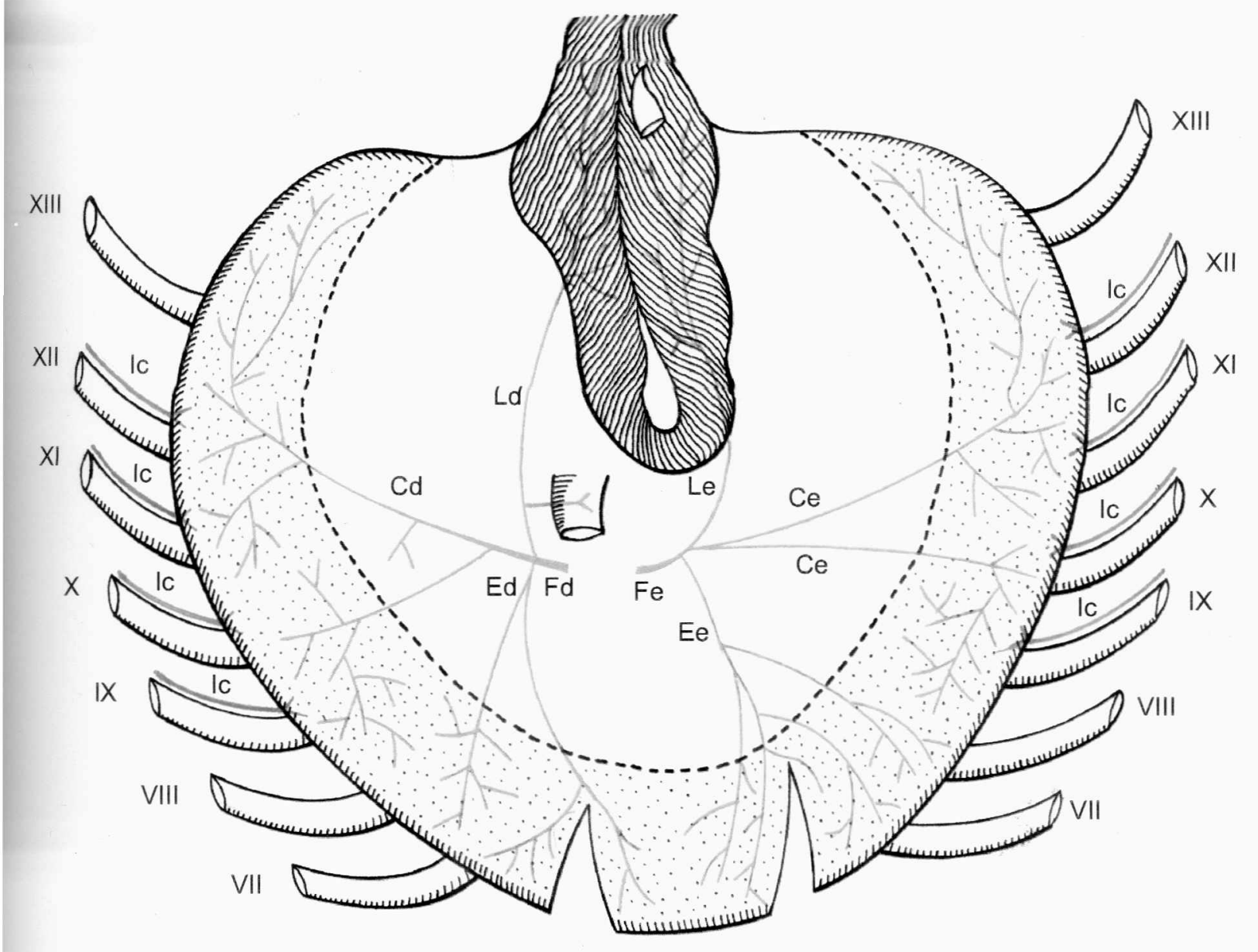

Obs. $6 \mathrm{~F}$ 


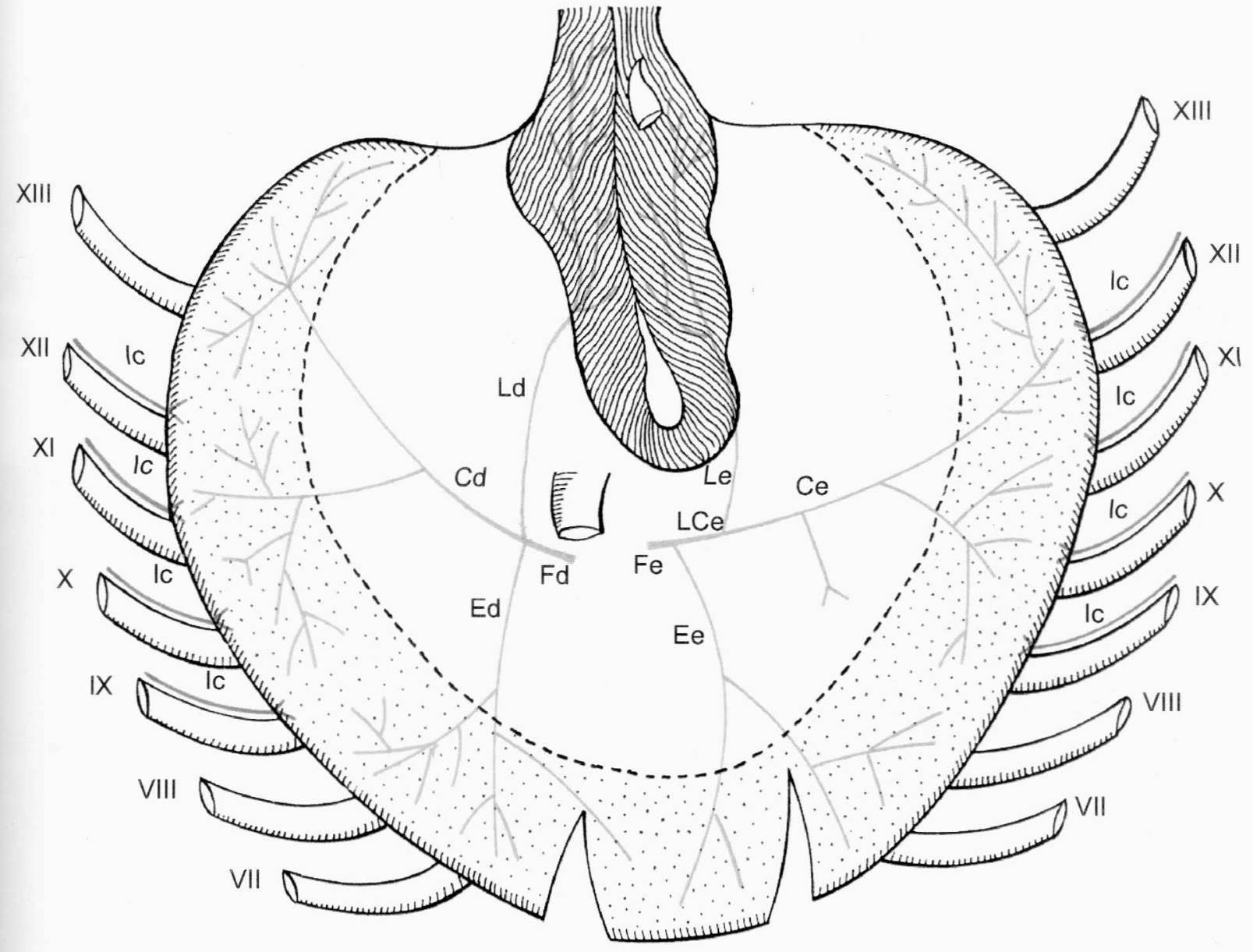

Obs. 7F 


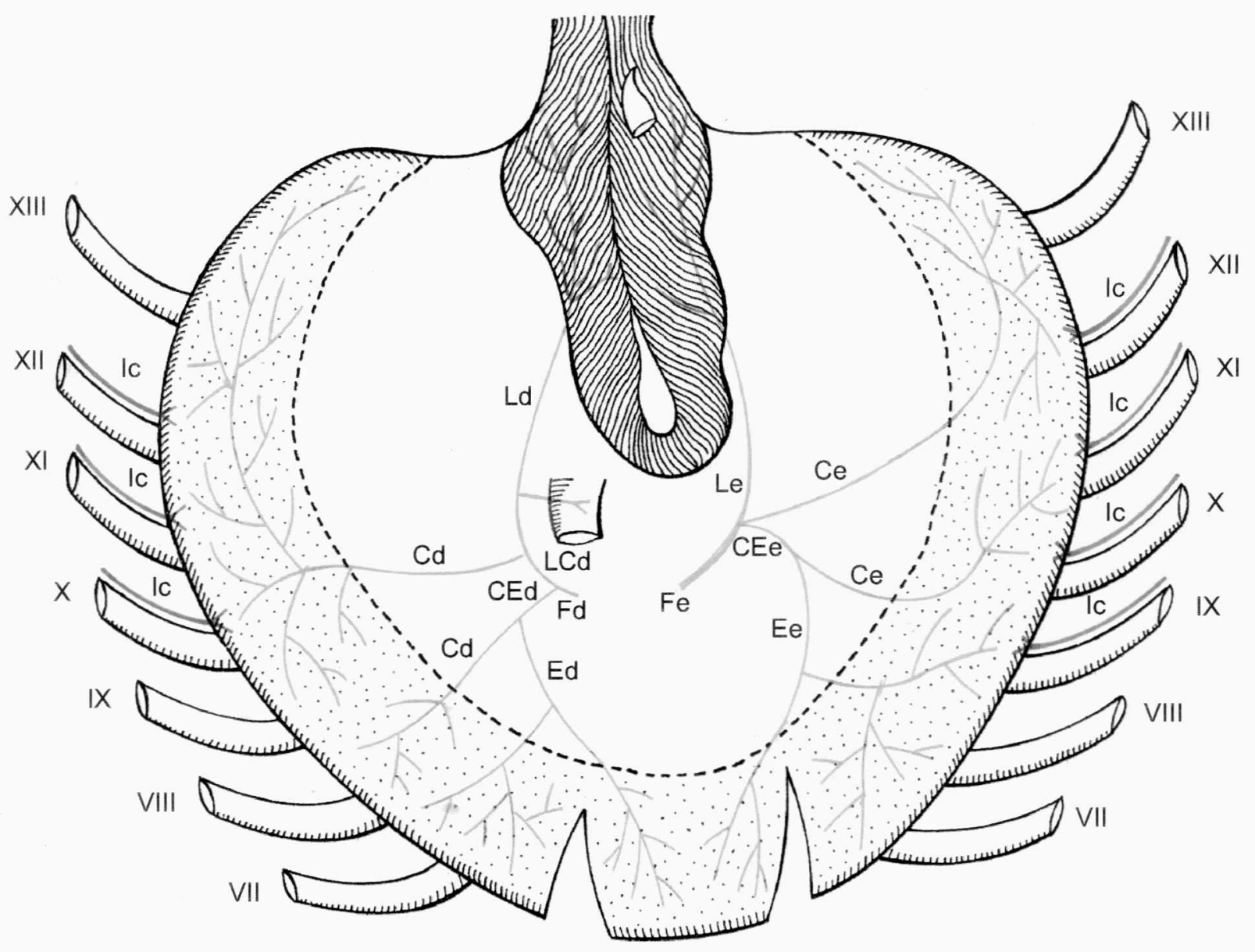

Obs. 8M 


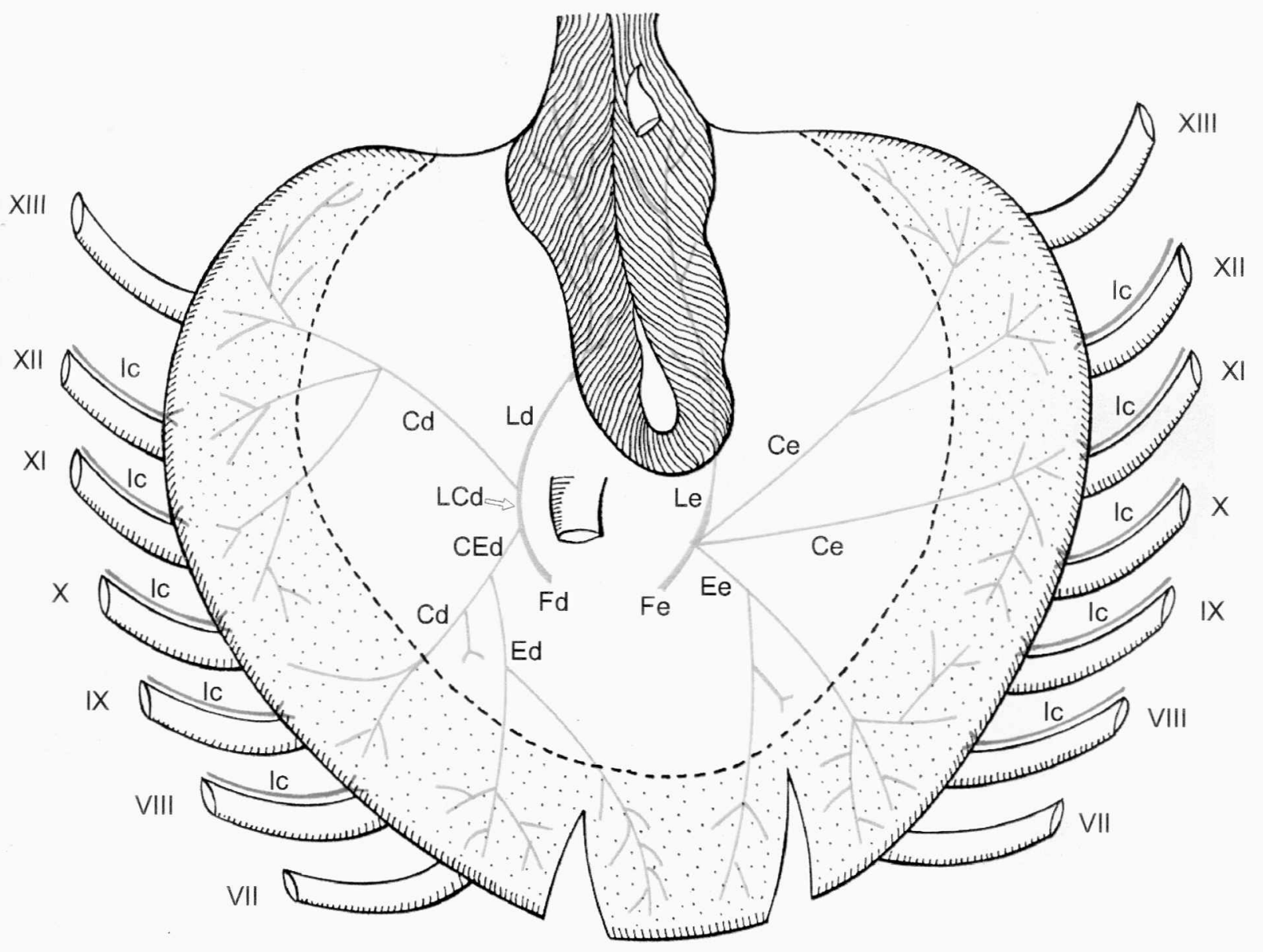

Obs. 9M 


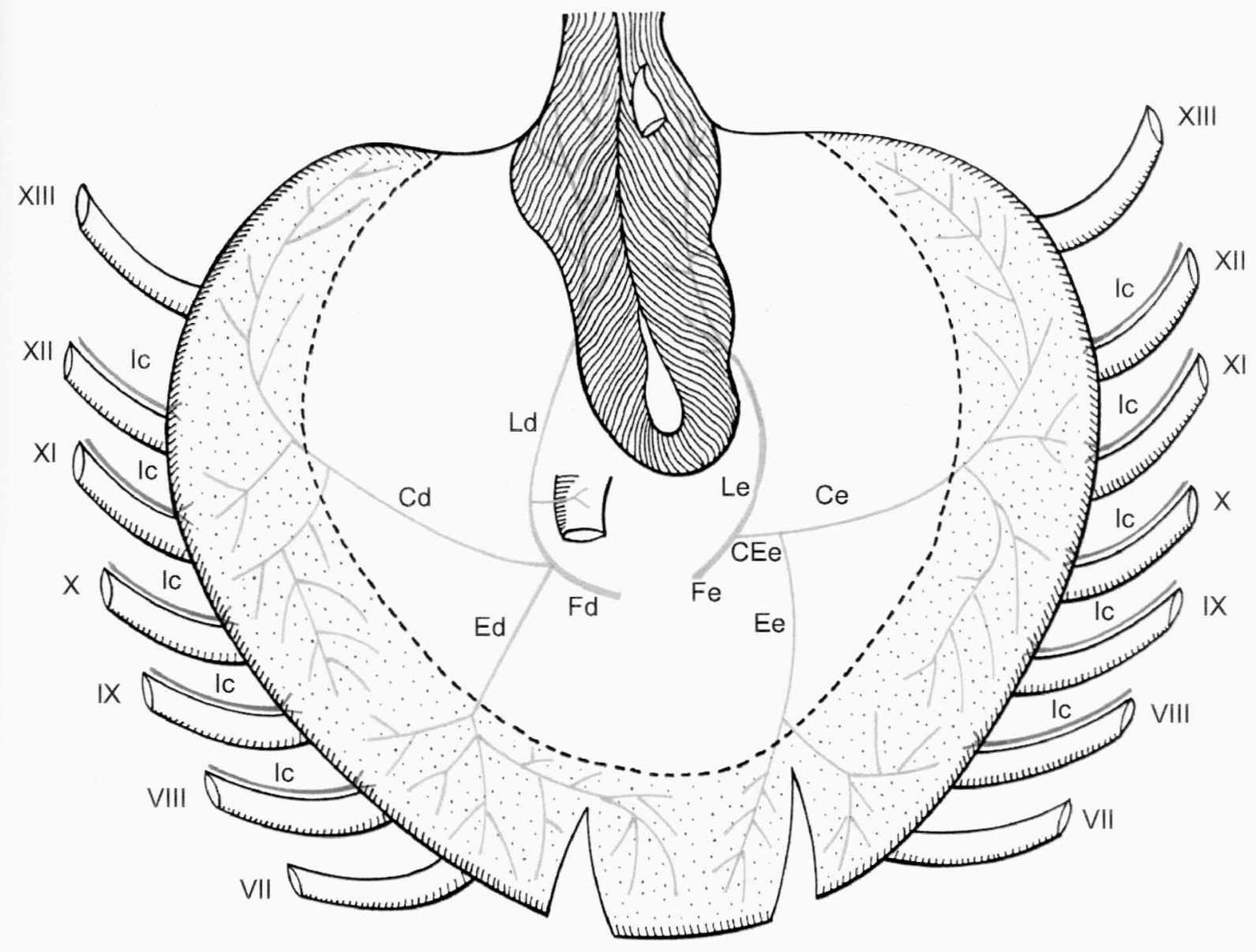

Obs. 10M 


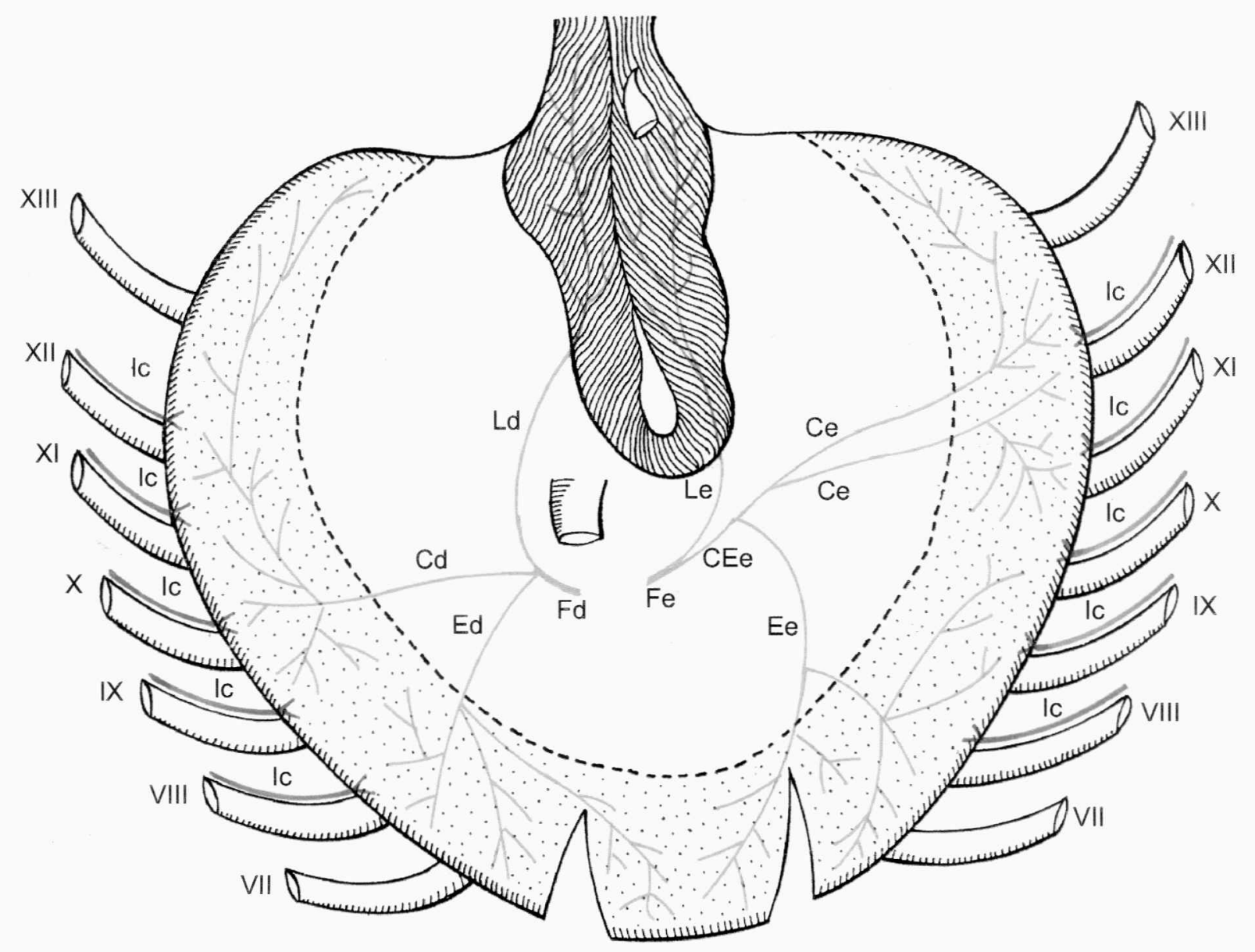

Obs. $11 \mathrm{M}$ 


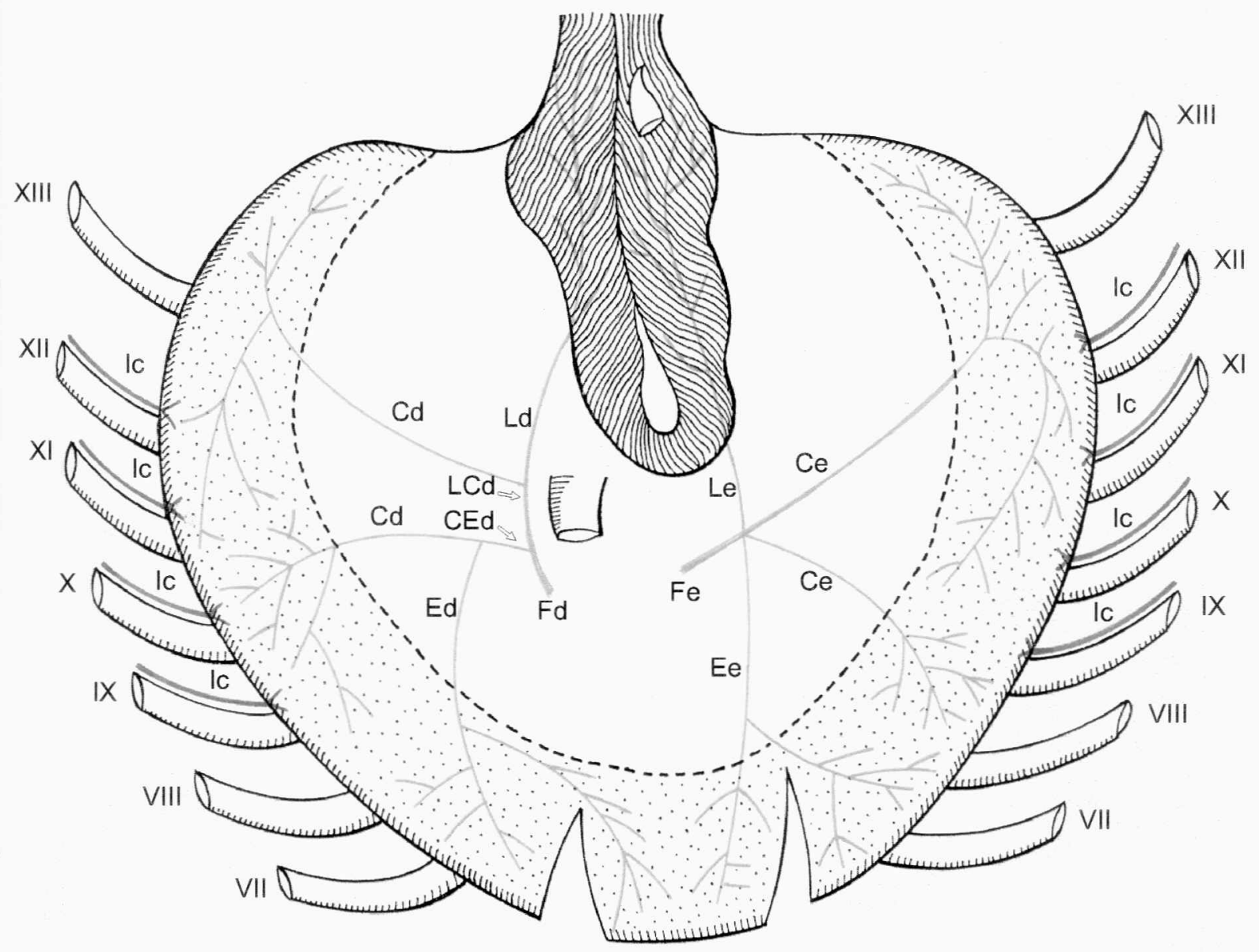

Obs. $12 \mathrm{M}$ 


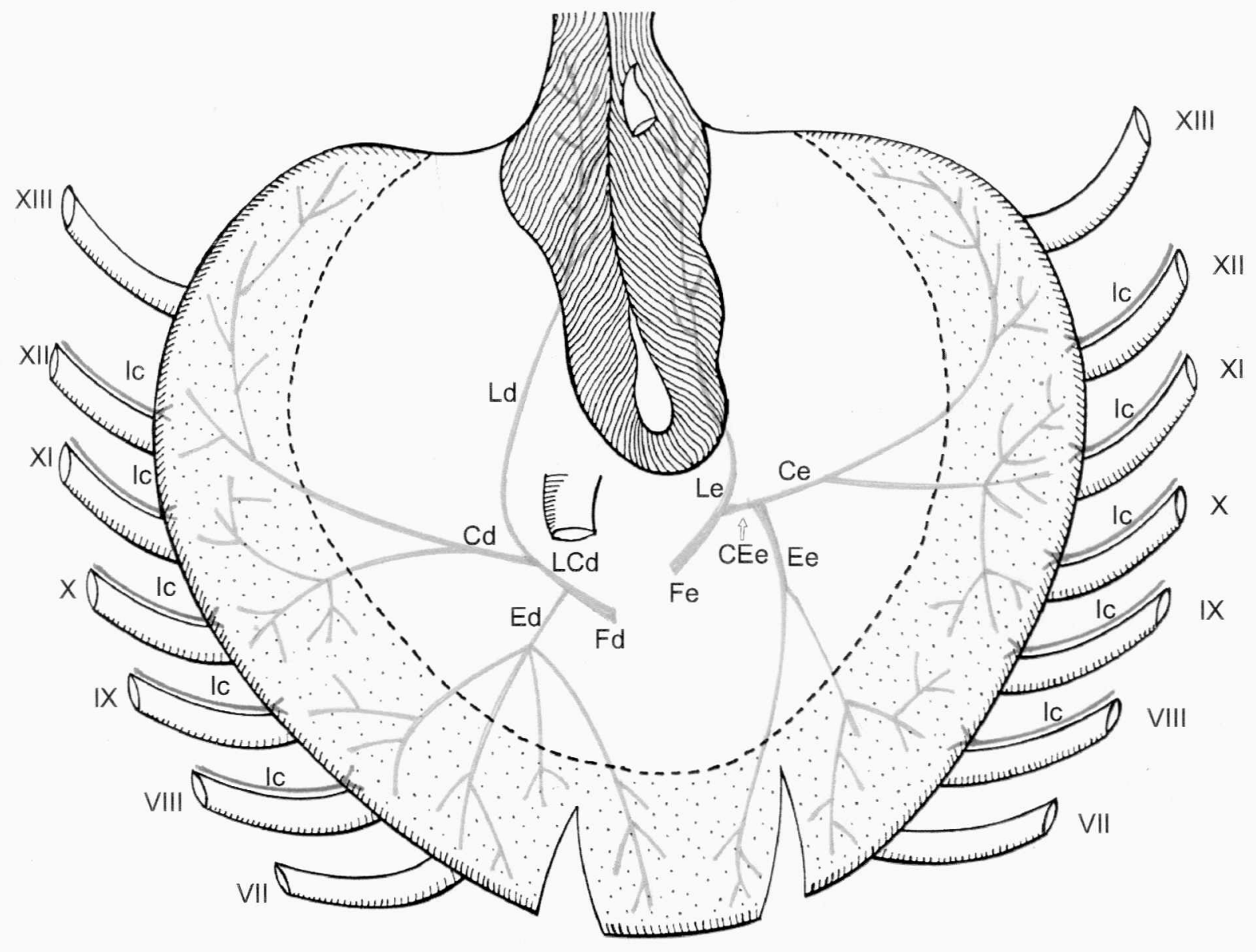

Obs. $13 \mathrm{M}$ 


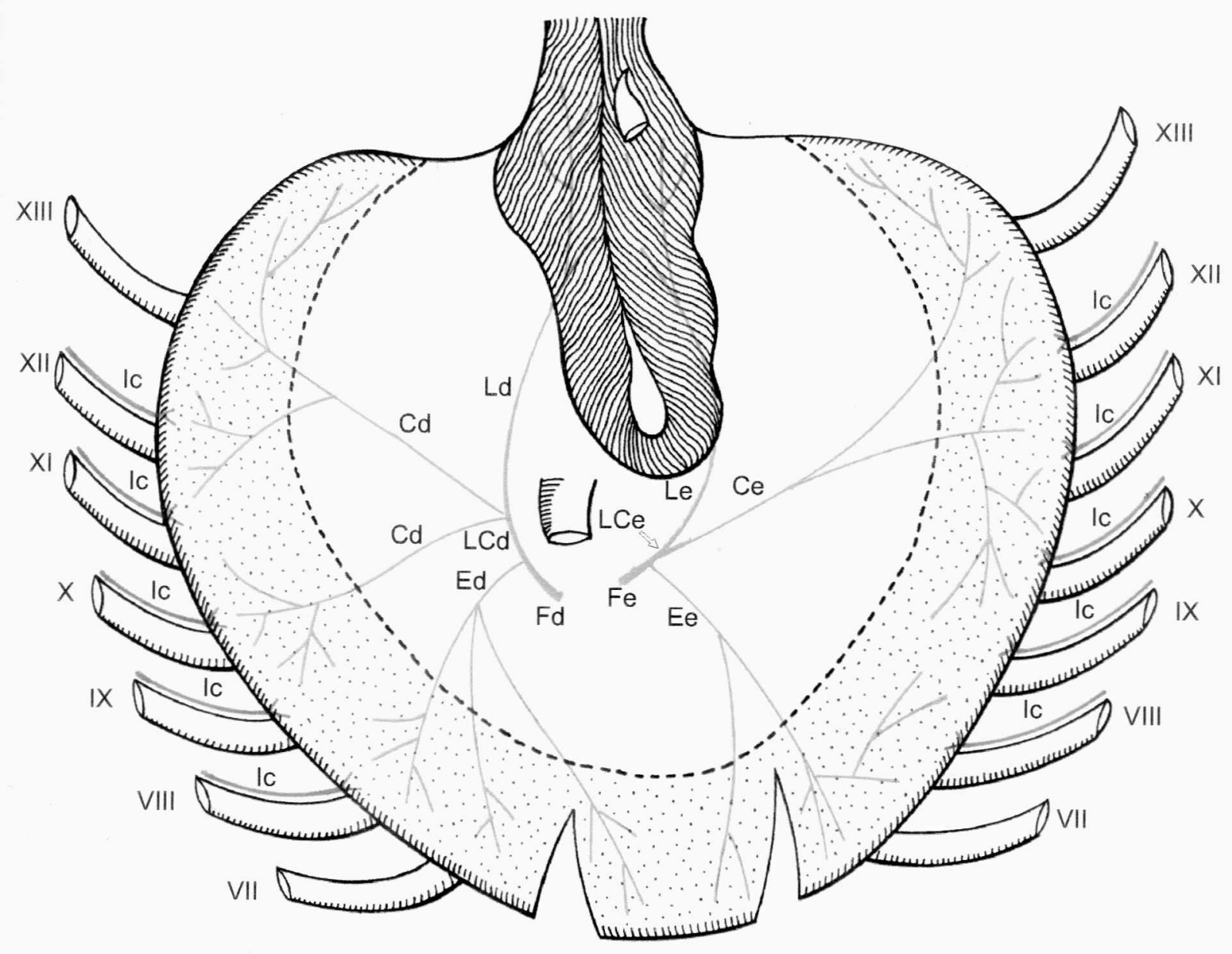

Obs. 14F 


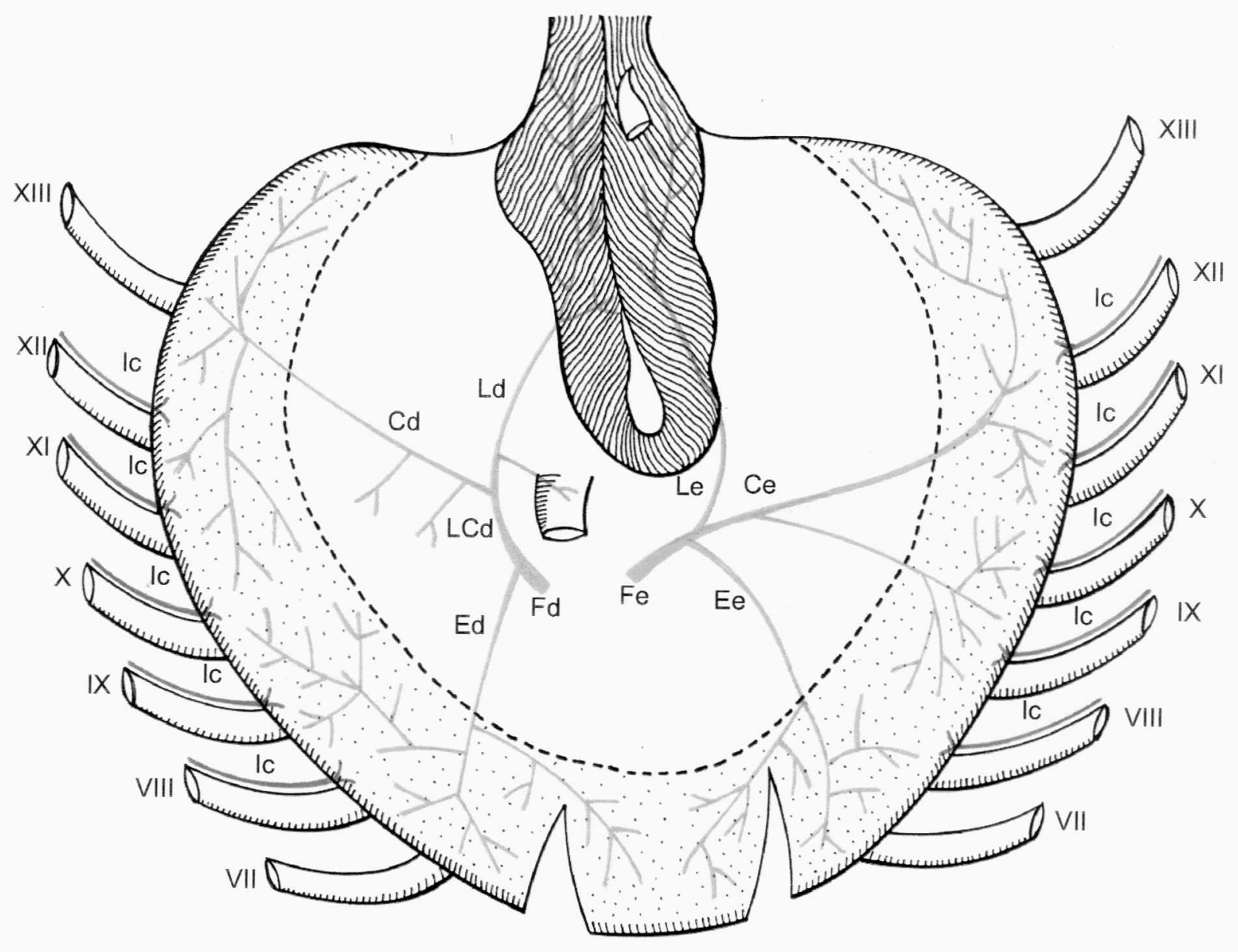

Obs. $15 \mathrm{~F}$ 


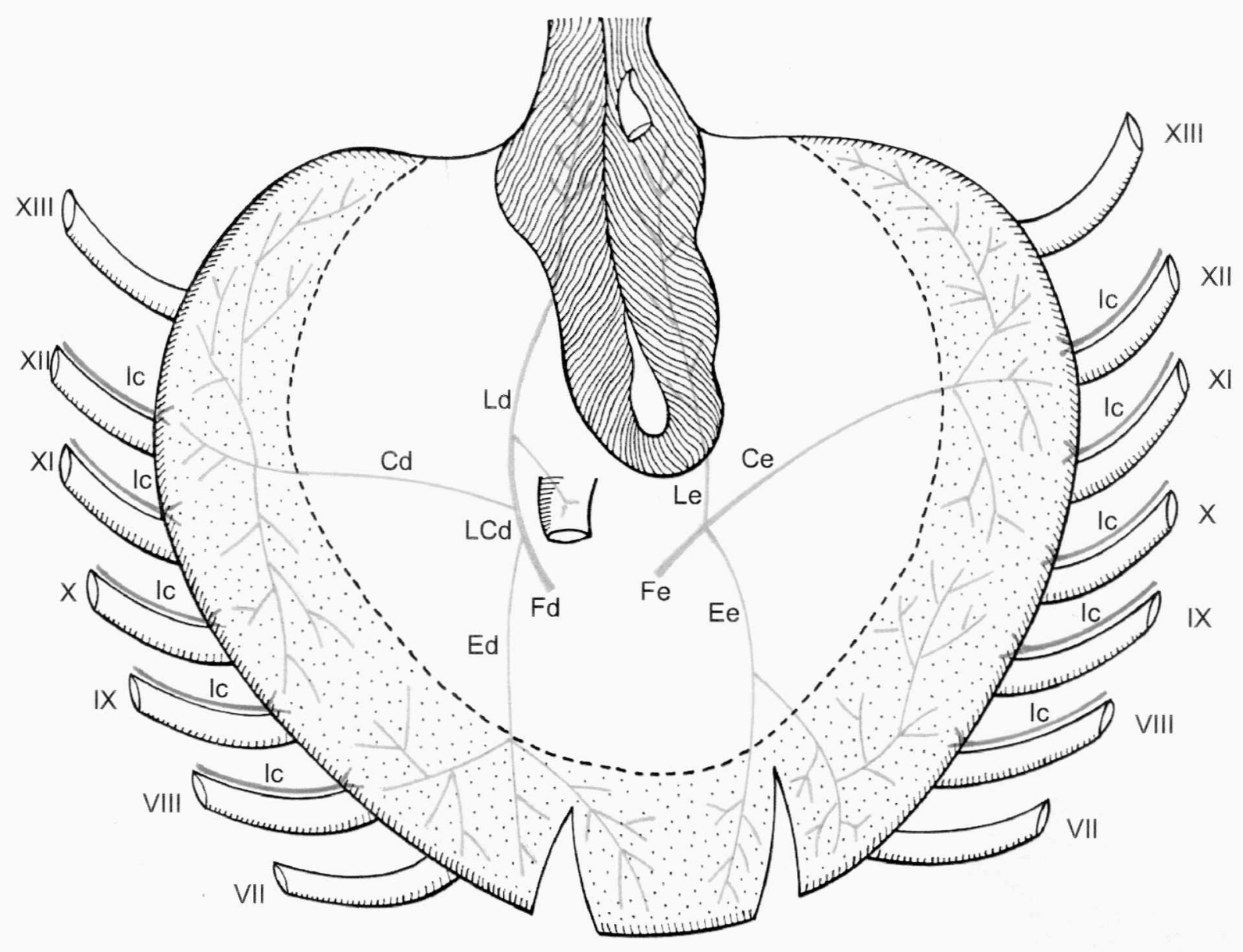

Obs. 16F 


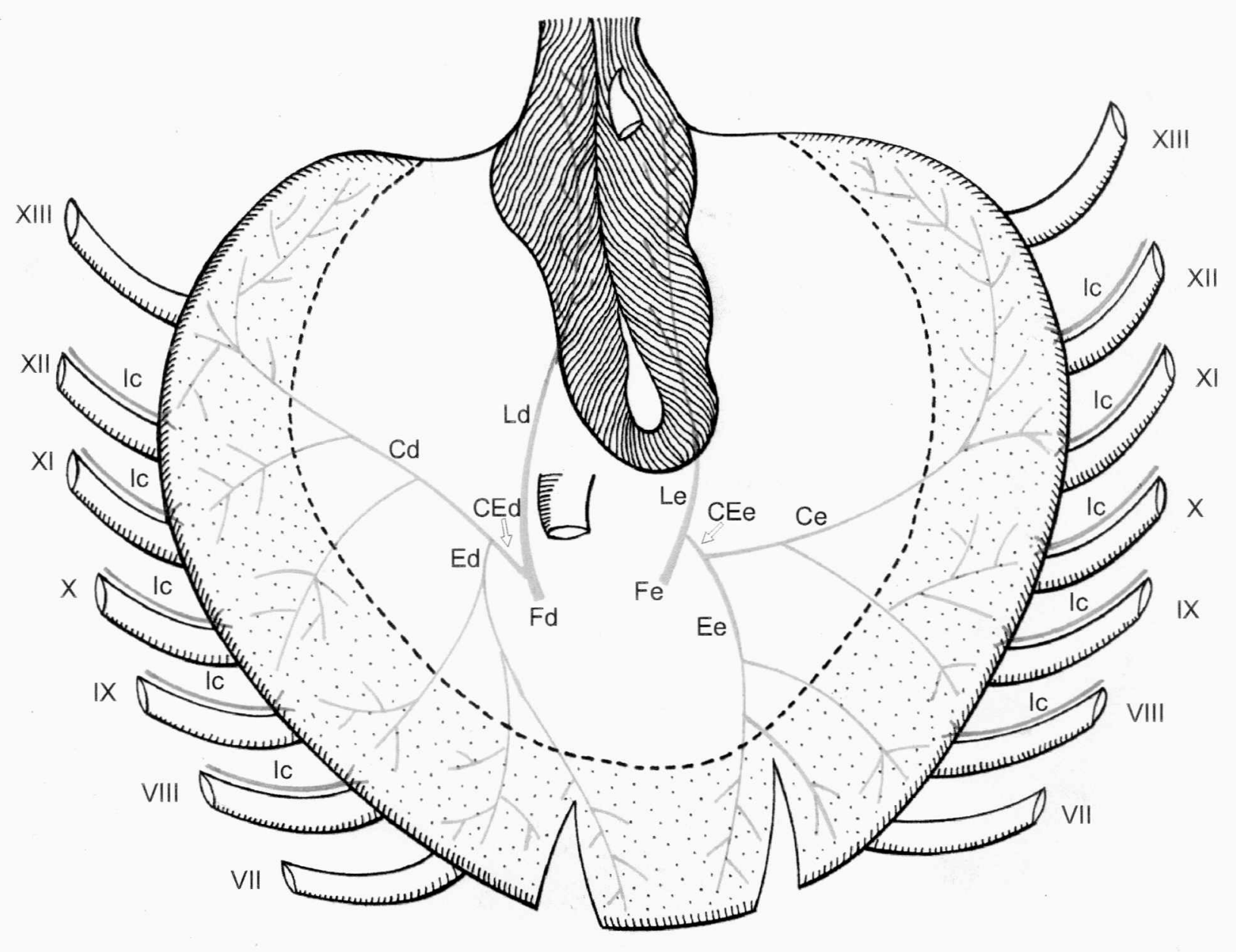

Obs. 17F 


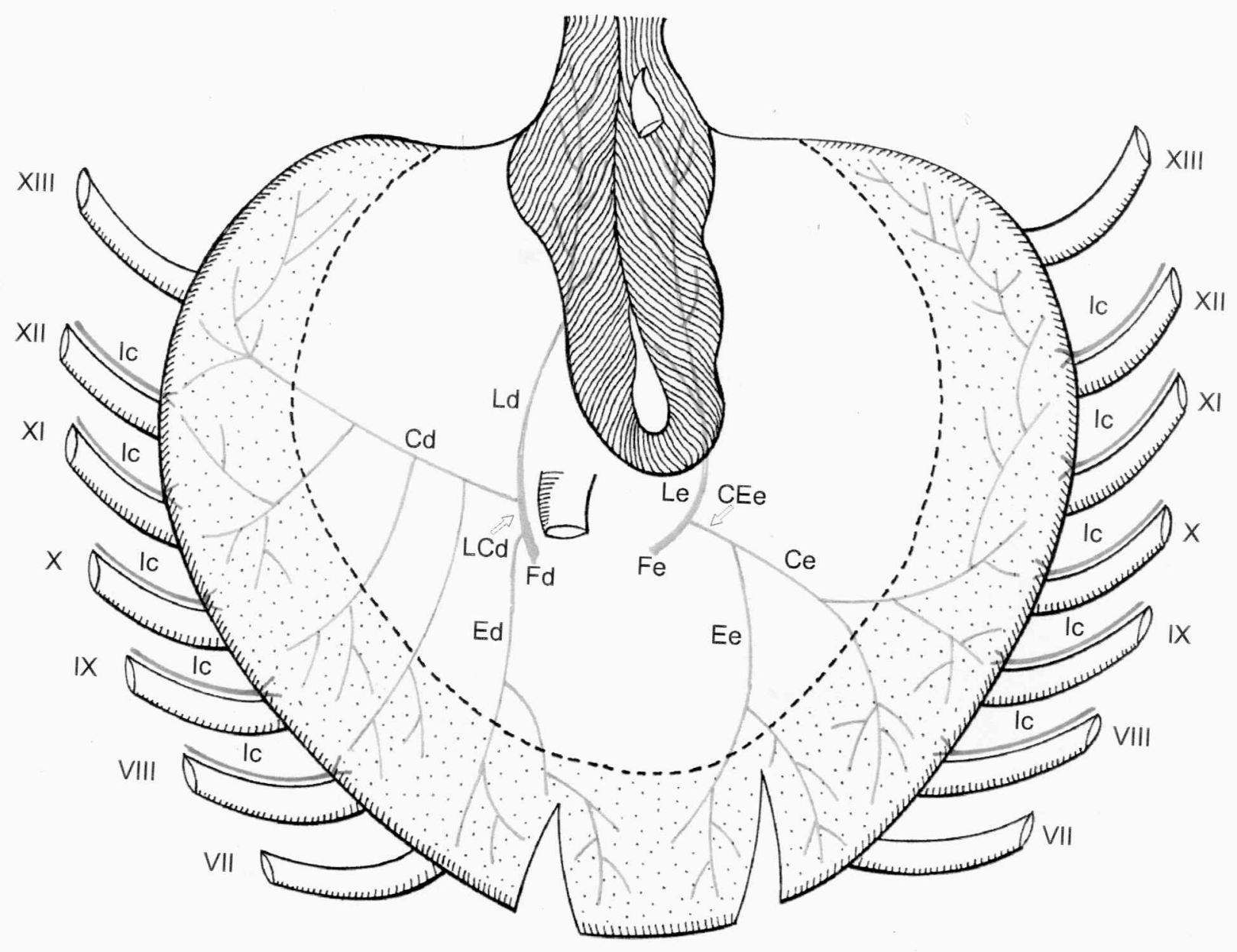

Obs.18M 


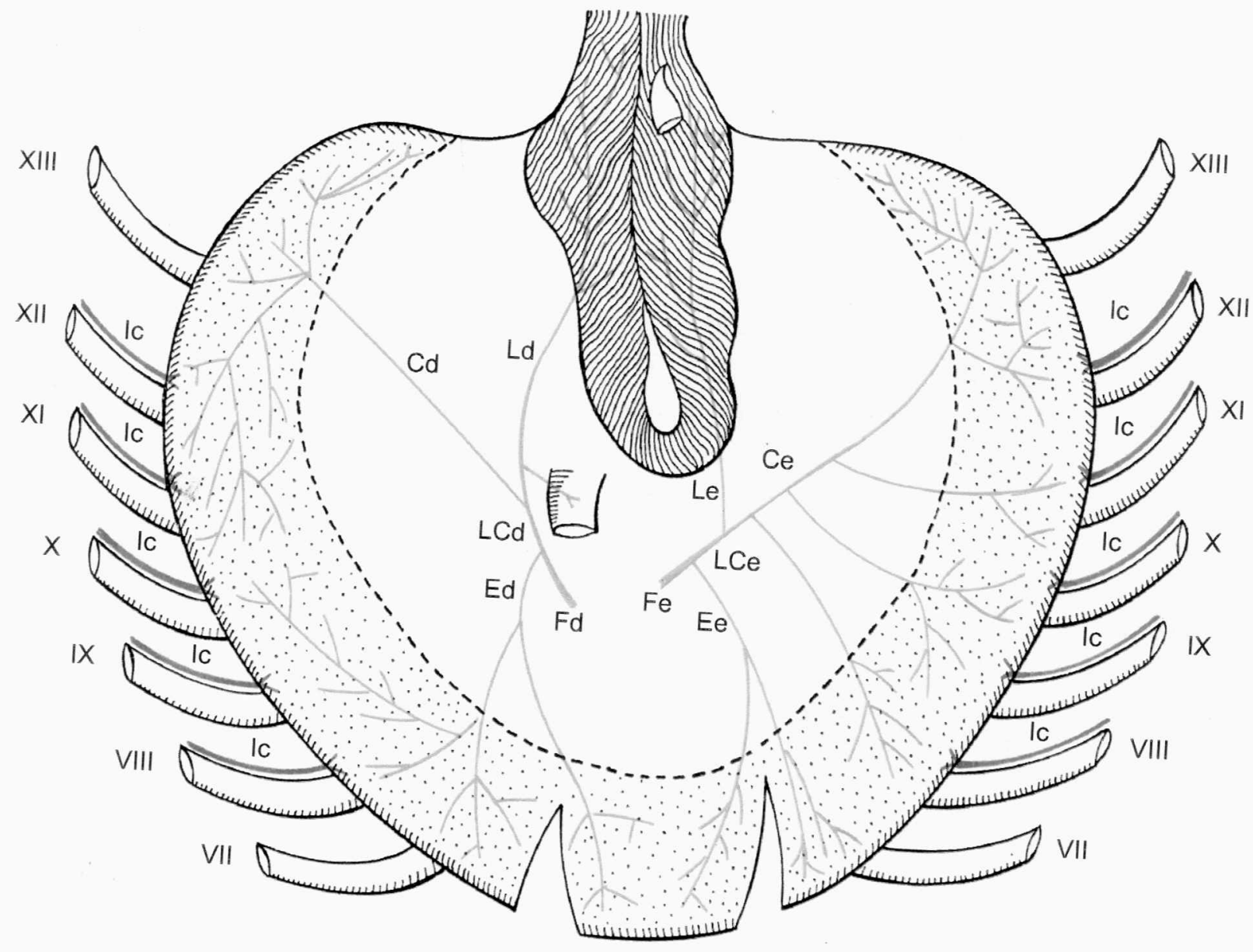

Obs.19F 


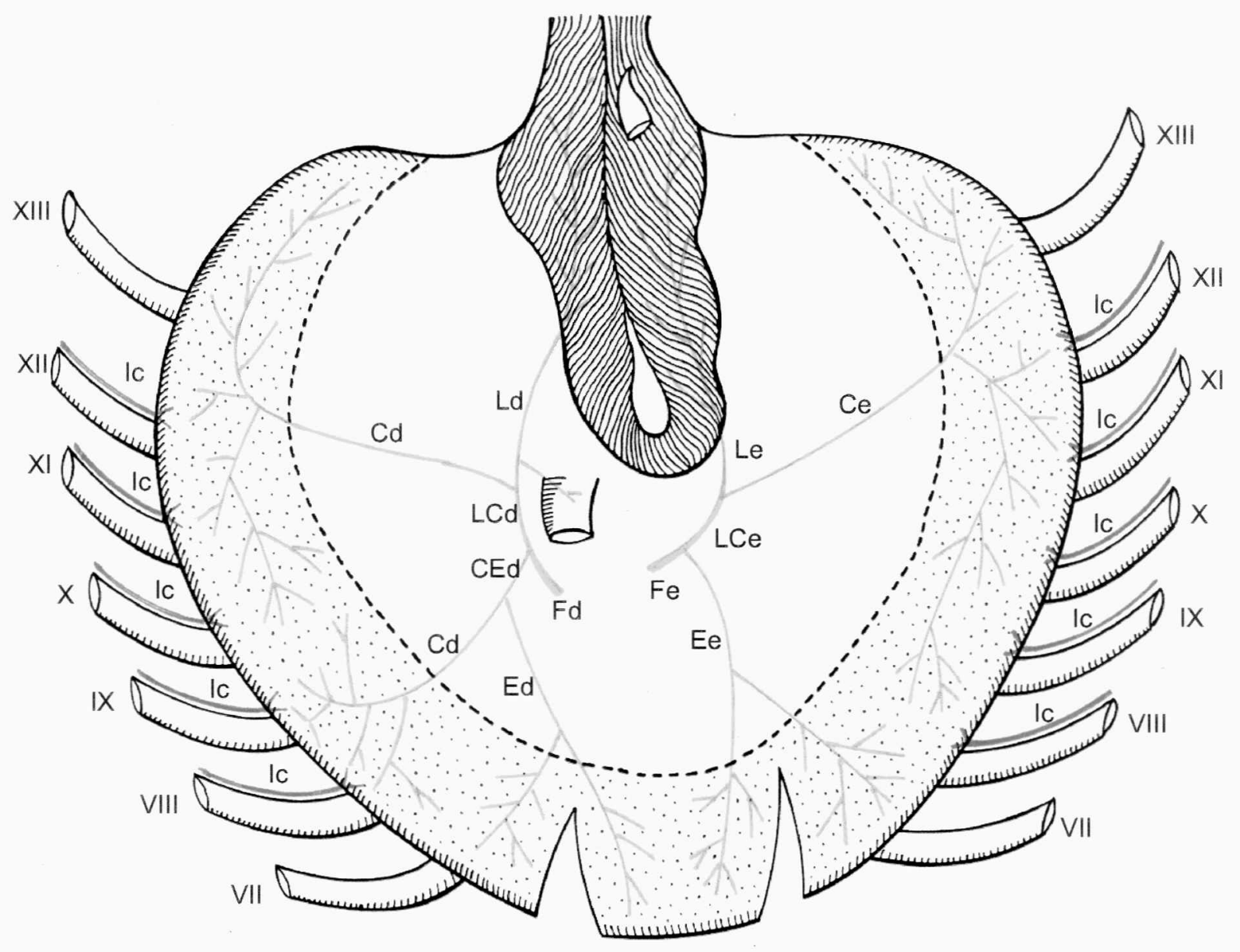

Obs. 20M 


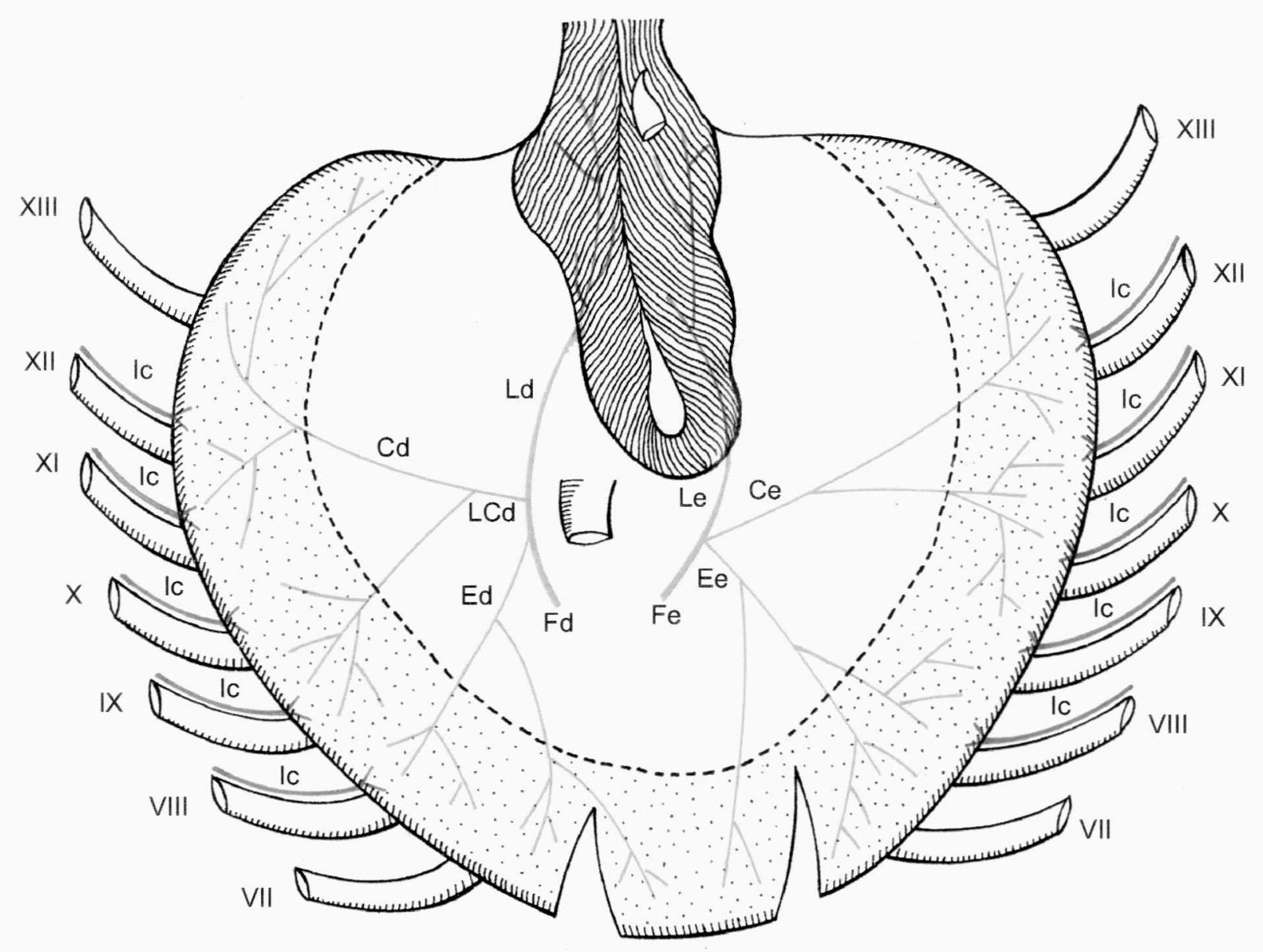

Obs. 21F 


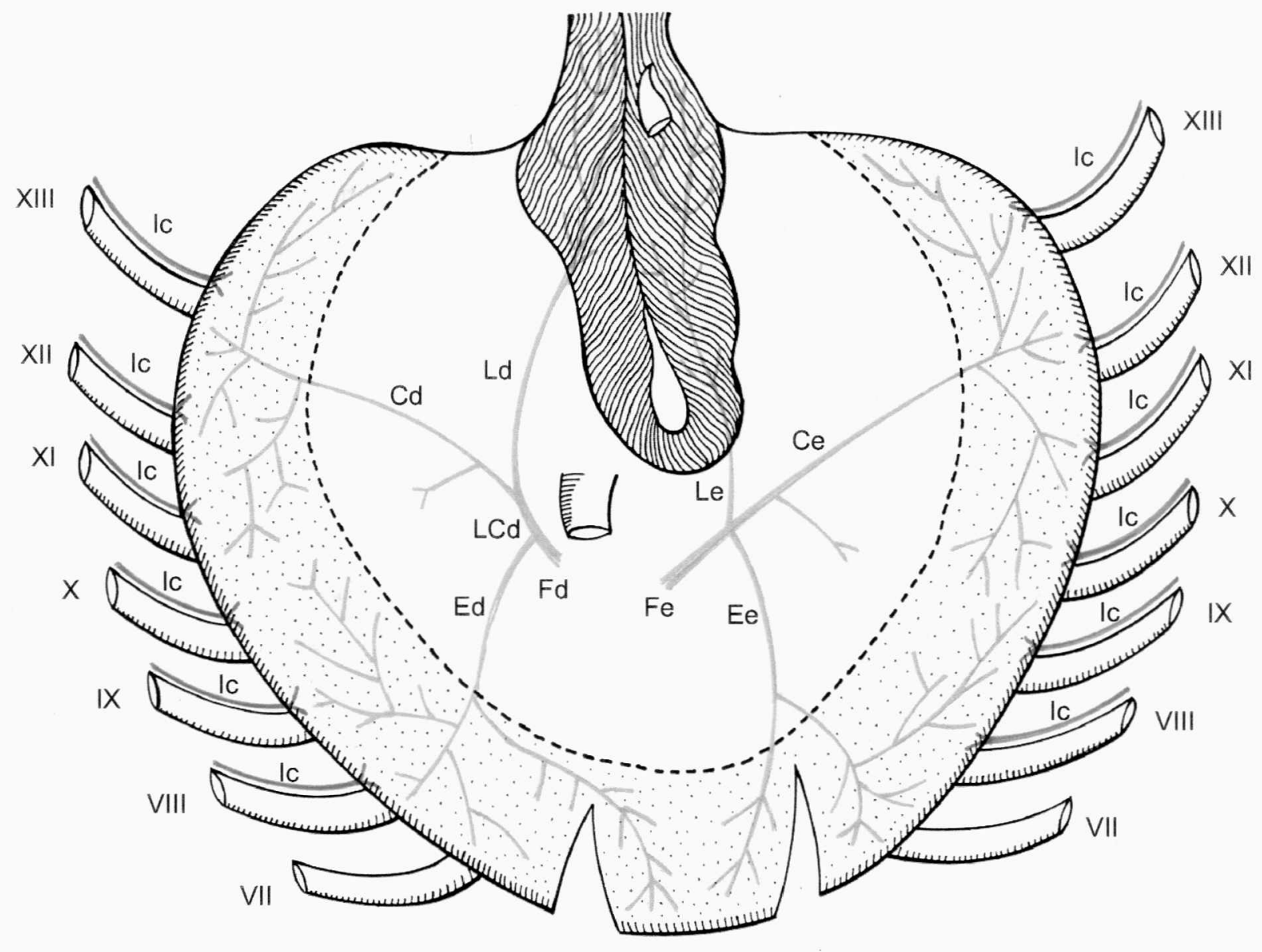

Obs. $22 \mathrm{M}$ 


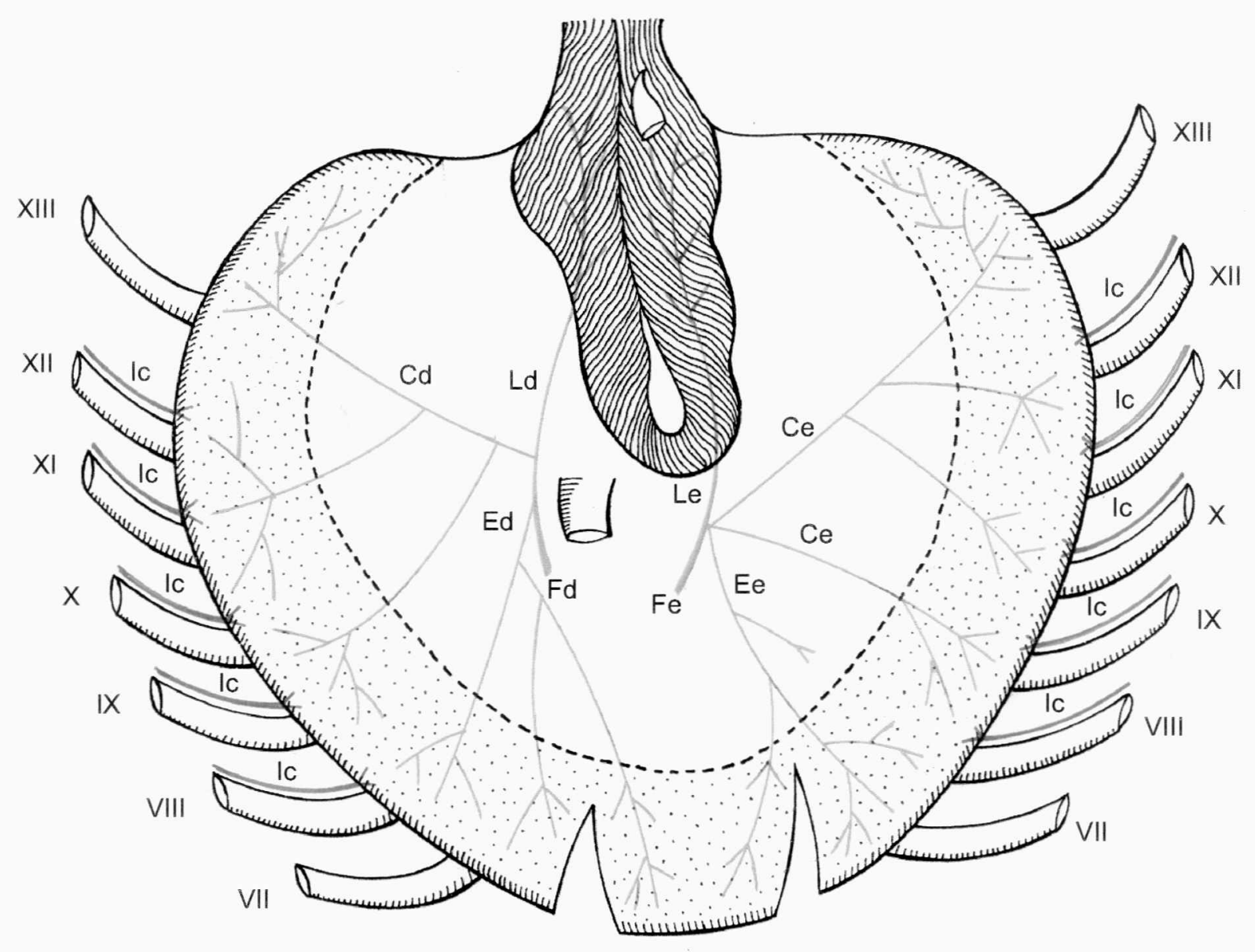

Obs. $23 \mathrm{M}$ 


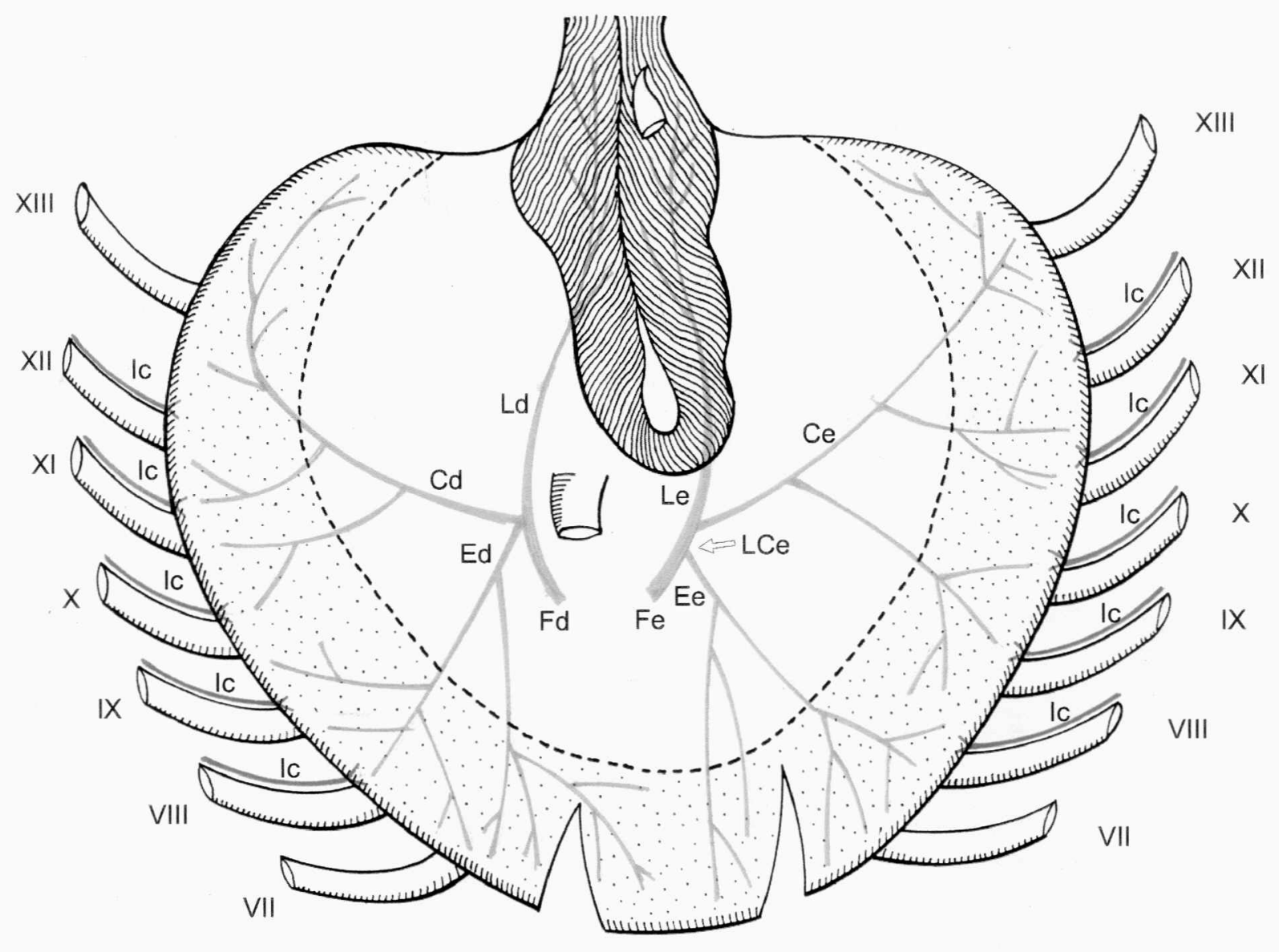

Obs. $24 \mathrm{M}$ 


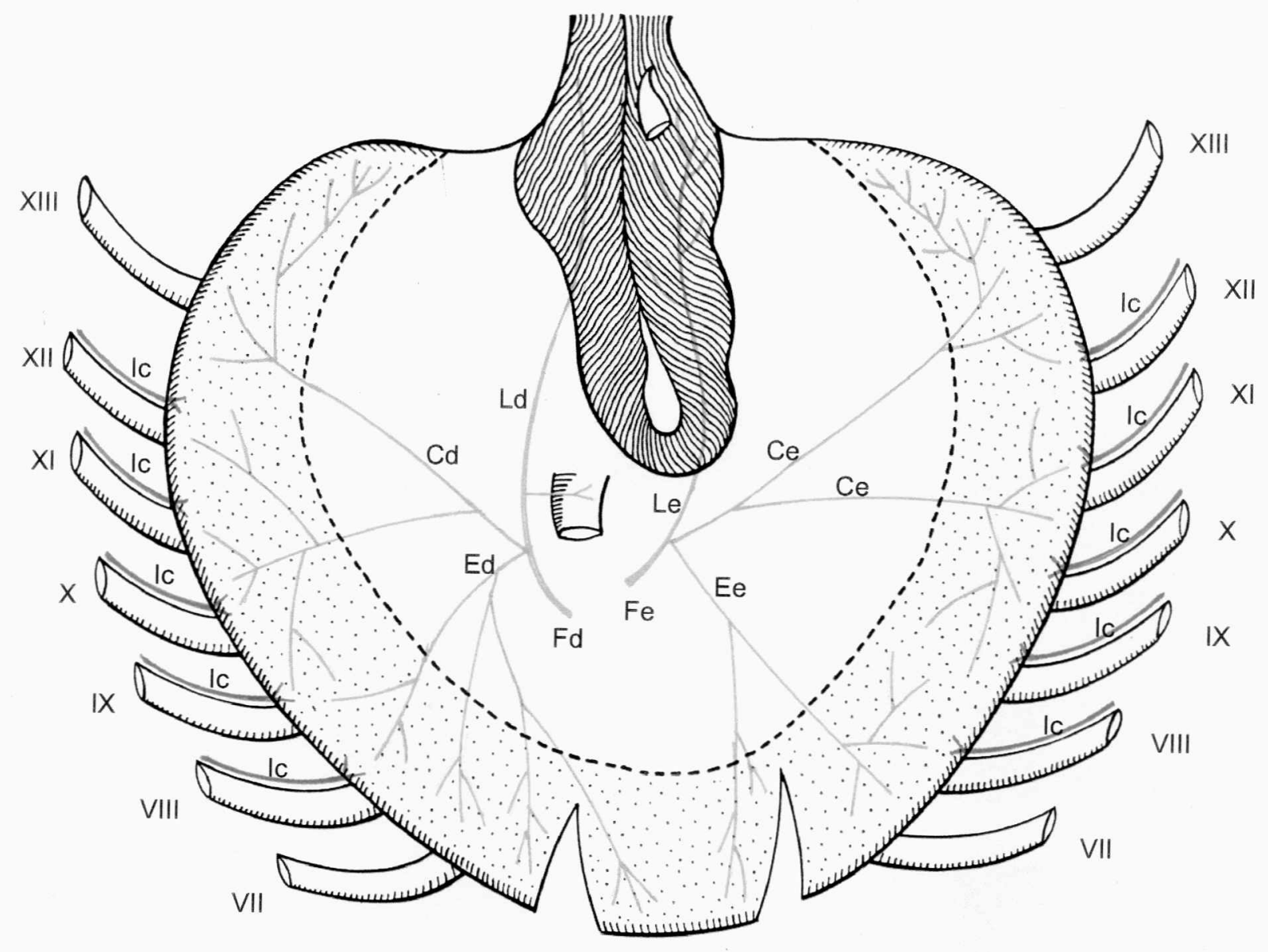

Obs. $25 \mathrm{M}$ 


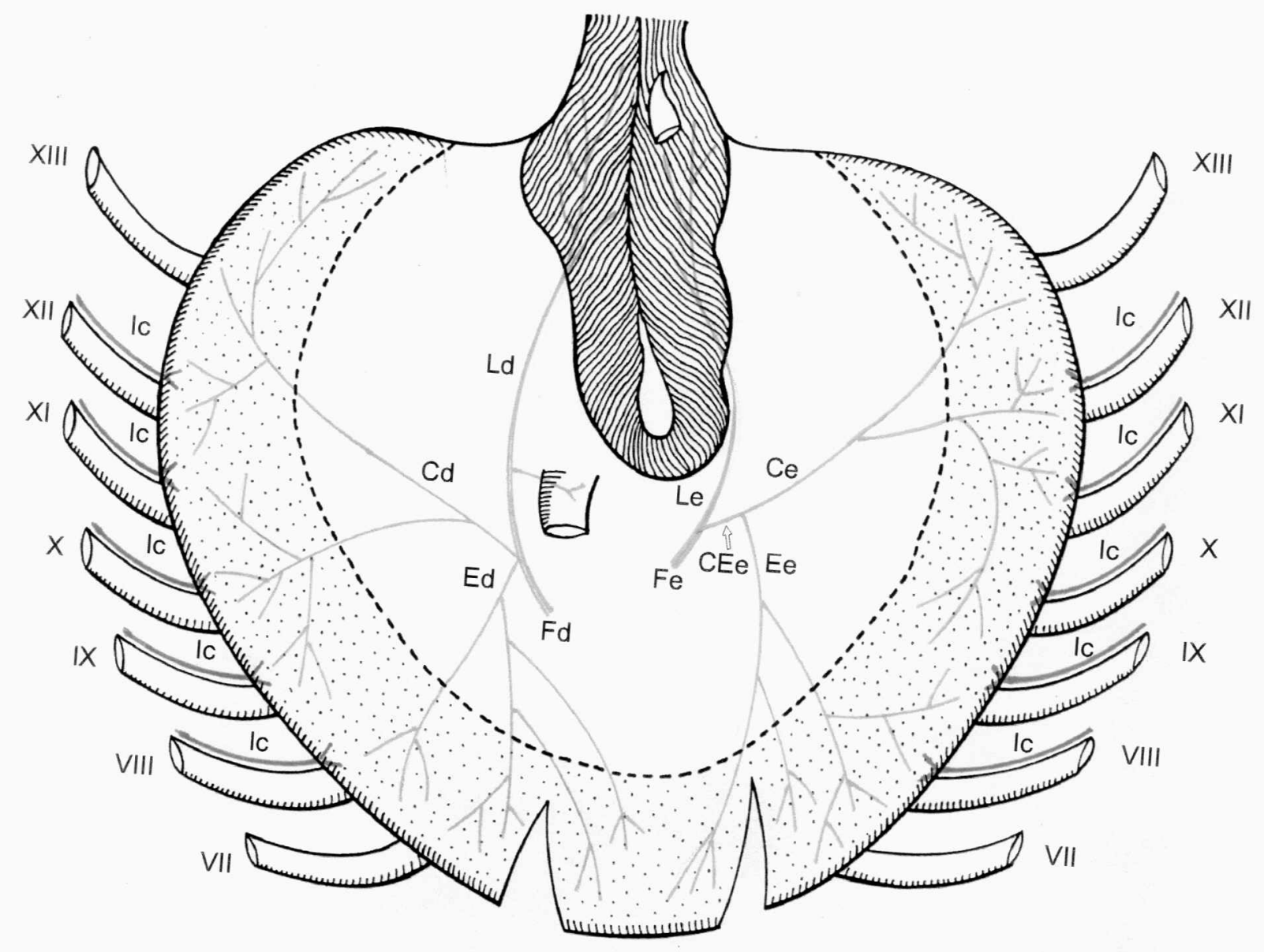

Obs. $26 \mathrm{M}$ 


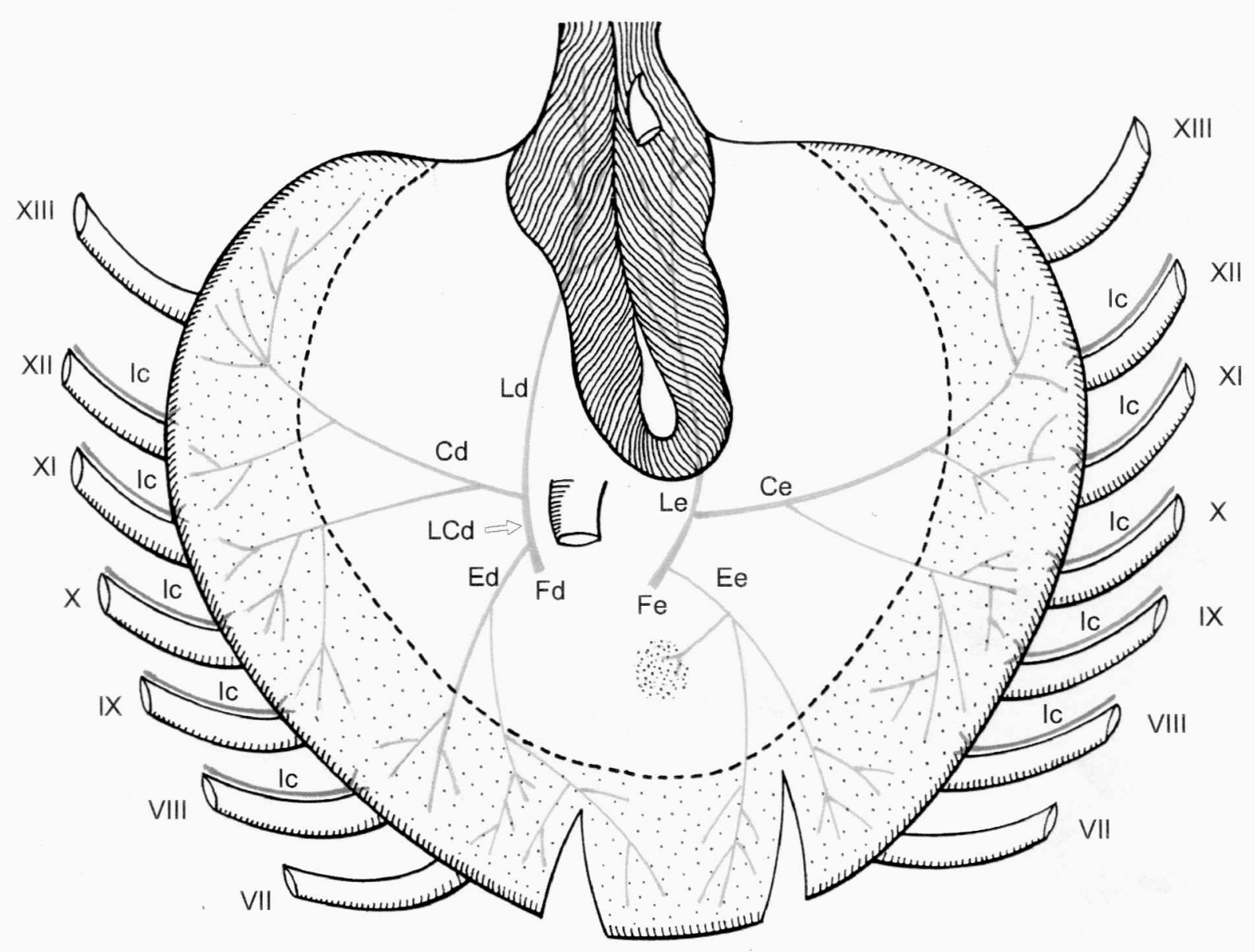

Obs. $27 \mathrm{M}$ 


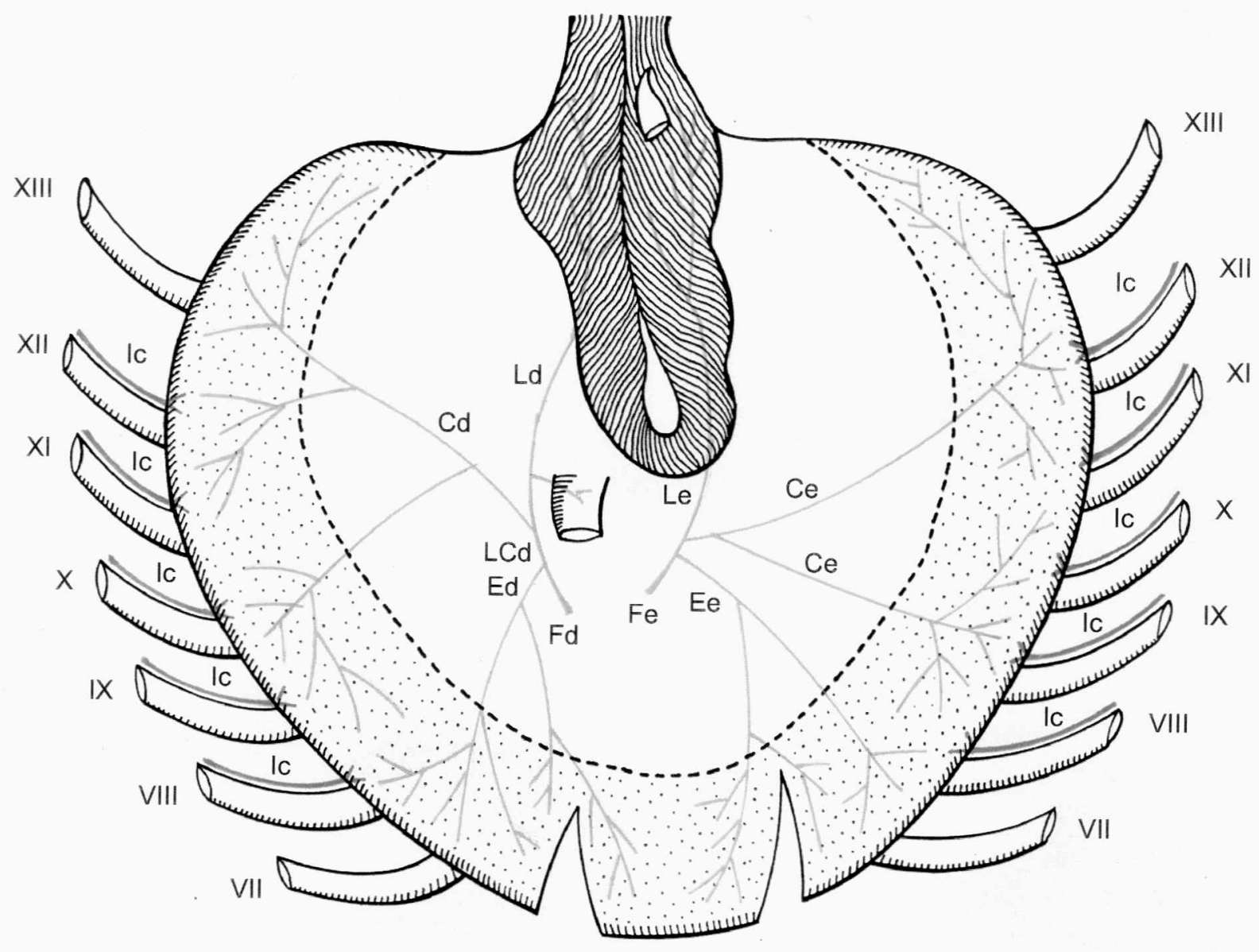

Obs. $28 \mathrm{M}$ 


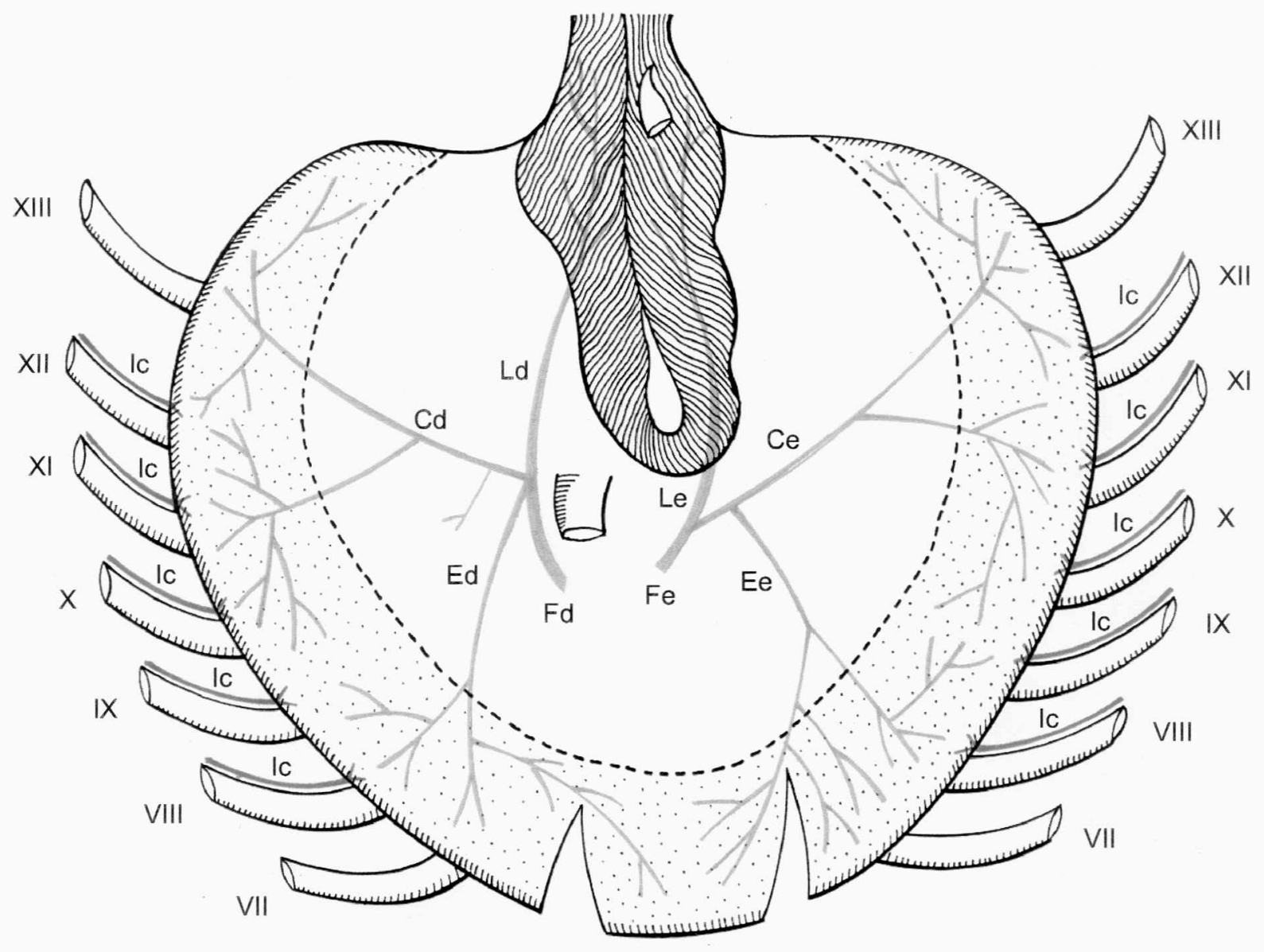

Obs. $29 \mathrm{M}$ 


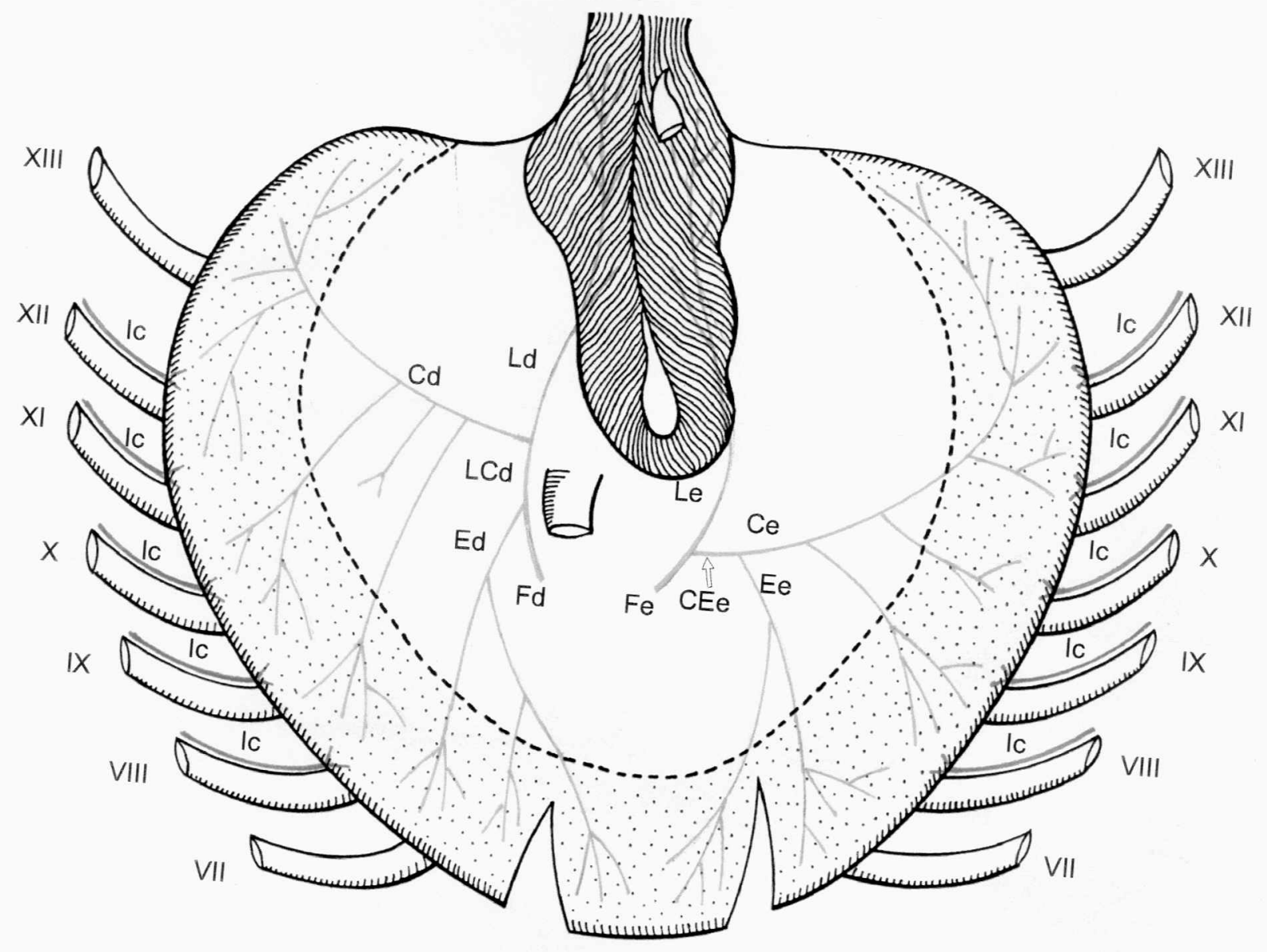

Obs. $30 \mathrm{M}$ 